Universidad de Lima

Facultad de Ingeniería Industrial

Carrera de Arquitectura

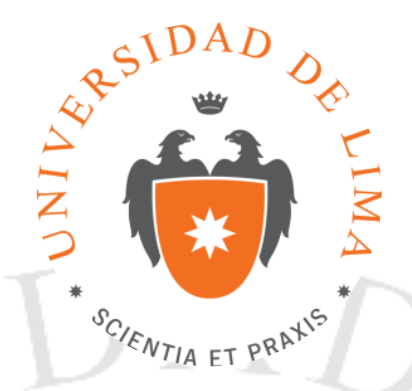

\title{
AMPLIACIÓN DEL MUSEO DE ARTE DE
}

LIMA

Tesis para optar el Título Profesional de Arquitecto

Luis Francisco Cabrera Osorio

Código 20102829

Asesora: Arq. Carmen Rivas

Lima - Perú

Junio de 2017 


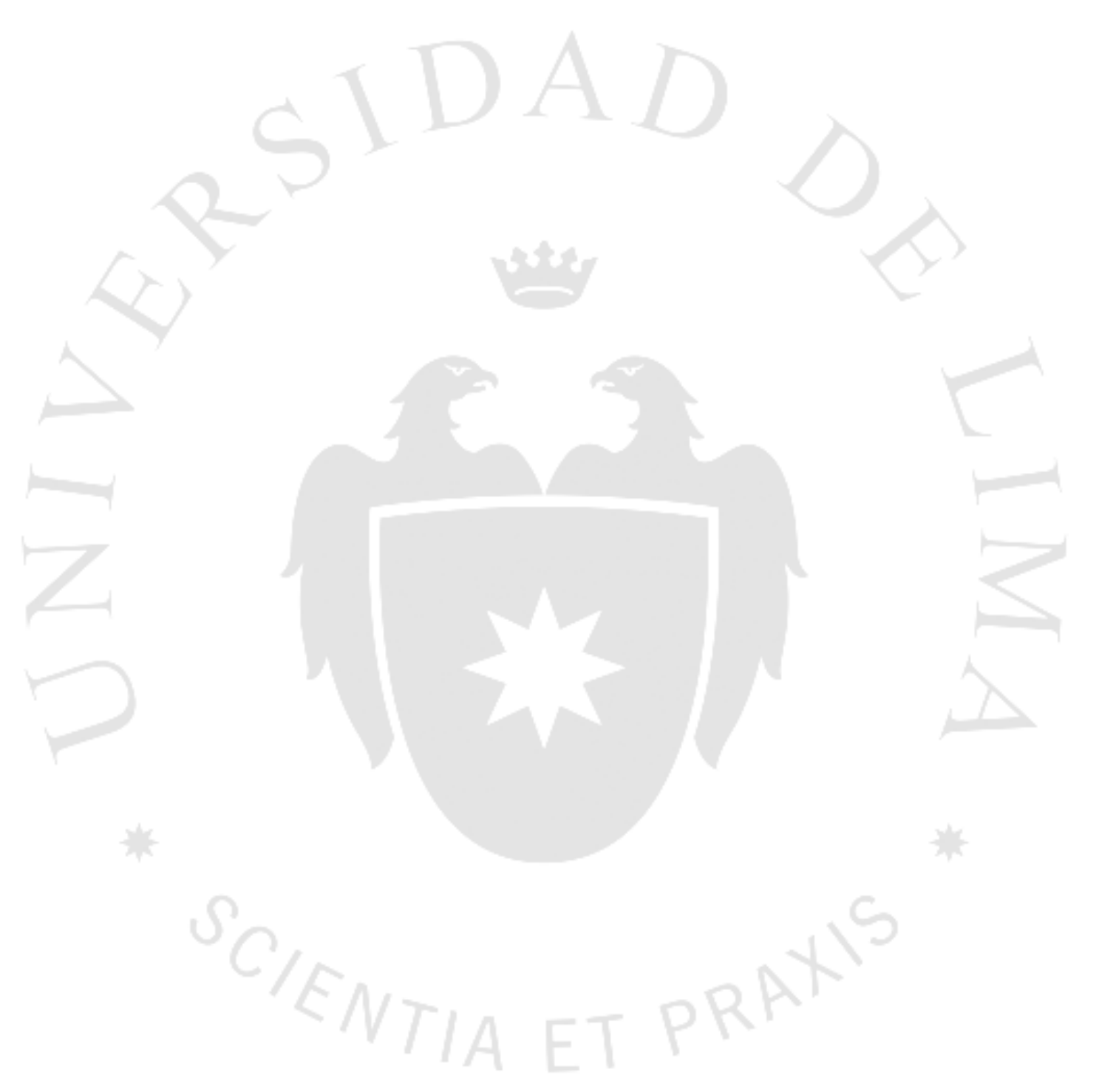


AMPLIACIÓN DEL MUSEO DE ARTE DE

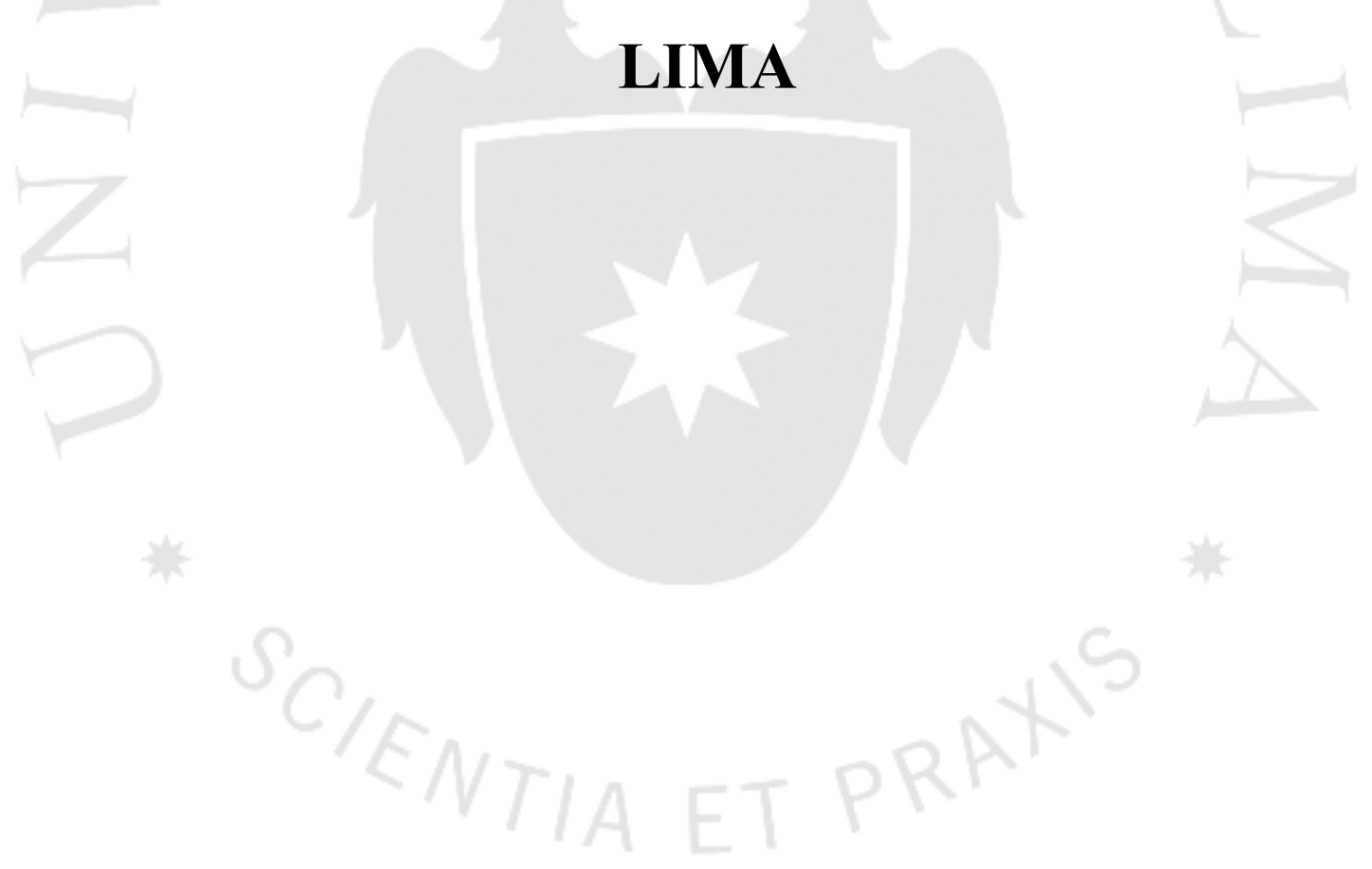

iii 


\section{TABLA DE CONTENIDO}

Introducción

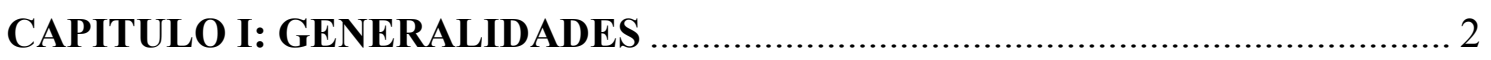

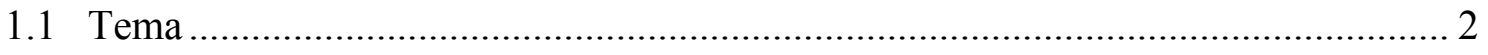

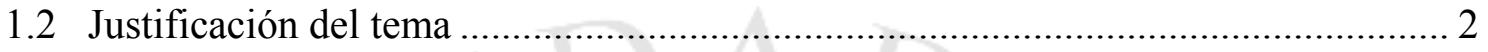

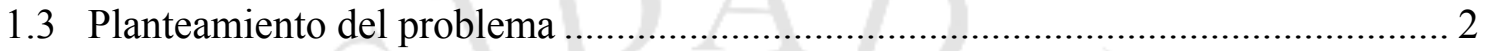

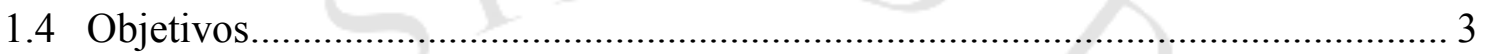

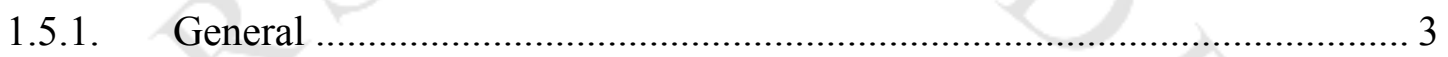

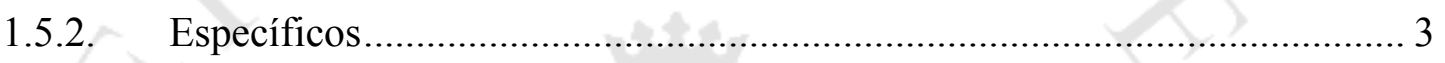

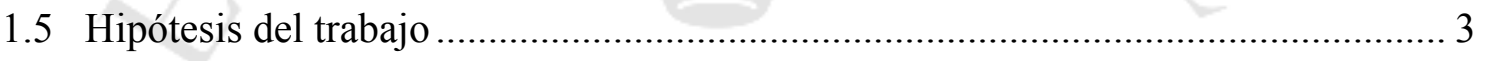

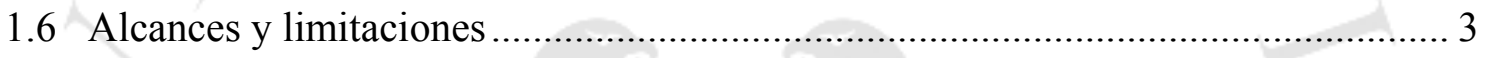

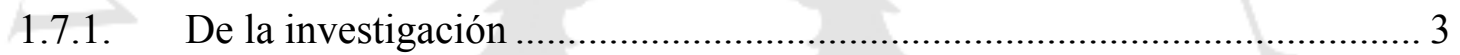

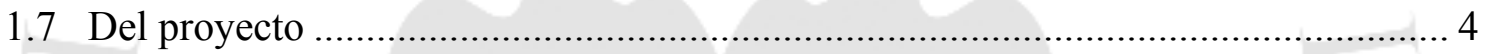

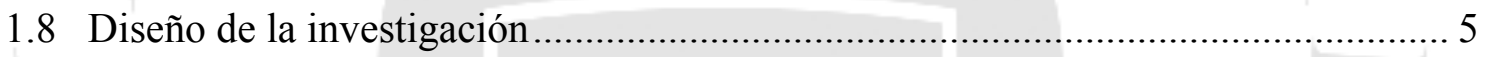

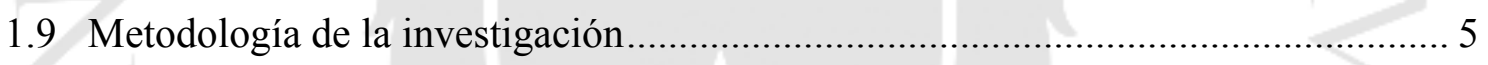

1.9.1 Forma de consulta de información ........................................................... 5

1.9.2 Forma de recopilación de la información..................................................... 5

1.9.3 Forma de análisis de la información.......................................................... 5

1.9.4 Forma de presentación de la información....................................................... 6

CAPÍTULO II: MARCO REFERENCIAL .............................................. 7

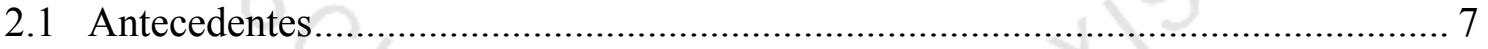

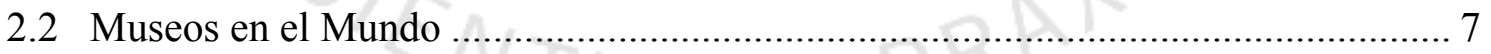

2.2.1 Línea de tiempo - Museos de relevancia histórica en el mundo...................... 9

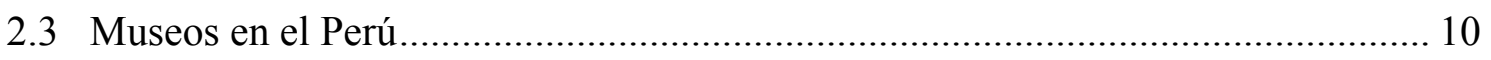

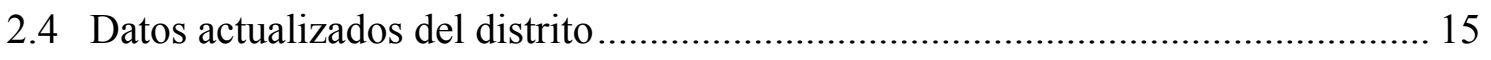

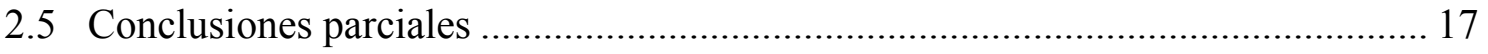

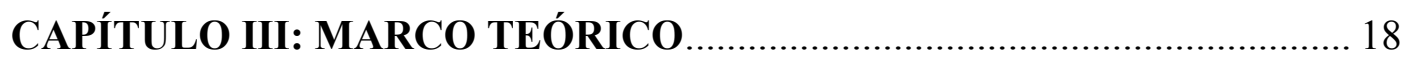

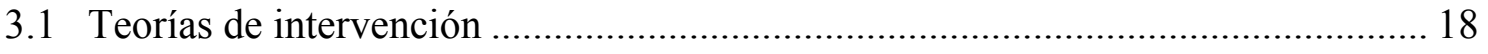

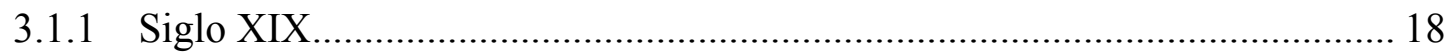




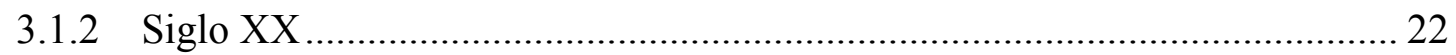

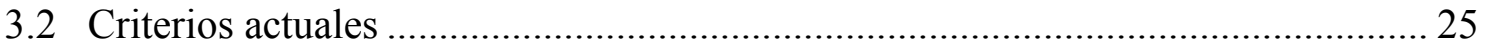

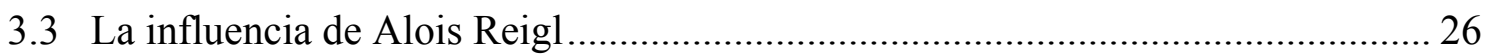

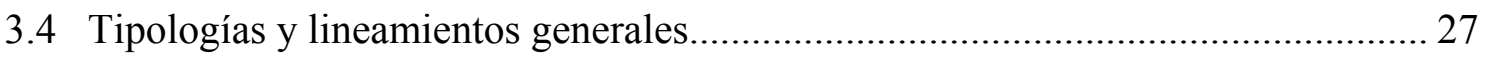

3.4.1 Tipos de museos (Architectural Review, 2012. Tipologías de museos): ....... 27

3.4.2 Lineamientos de Ernest Neufert para habilitación de museos y salas de

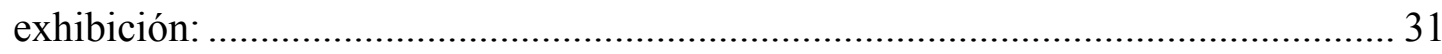

3.4.3 Definiciones, clasificación y consideraciones generales para proyectar un

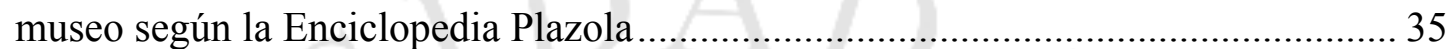

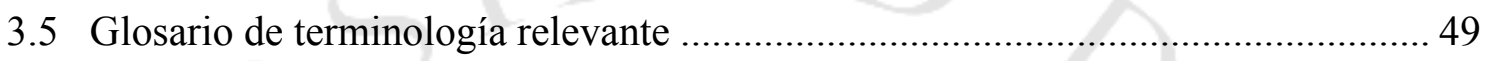

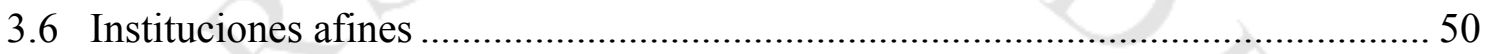

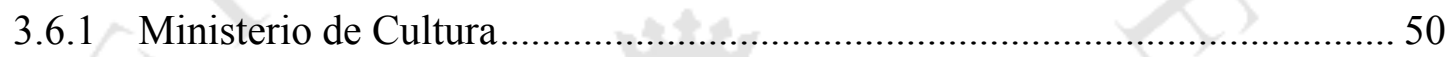

3.6.2 Ministerio de Vivienda (Reglamento Nacional de Edificaciones) .................. 50

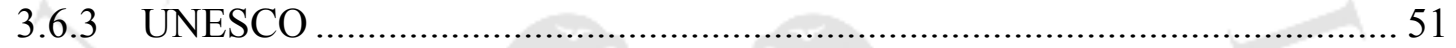

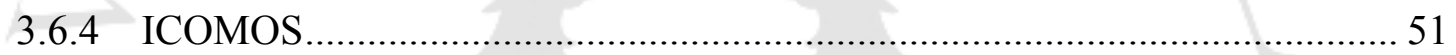

3.7 Normativa de intervención en el Centro de Lima................................................... 51

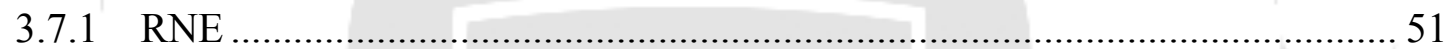

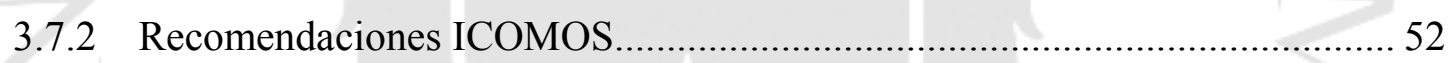

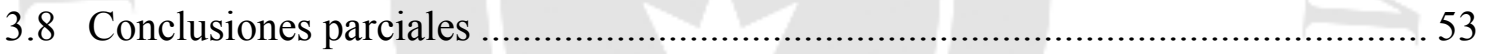

CAPÍTULO IV: MARCO OPERATIVO .................................................... 54

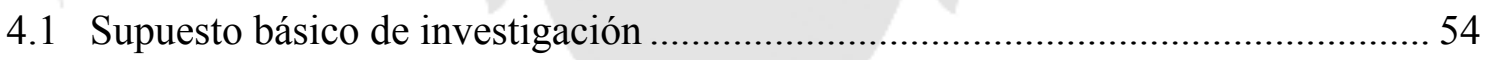

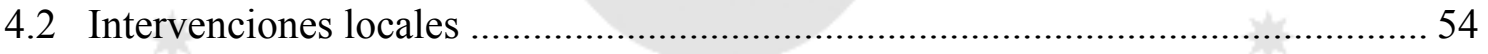

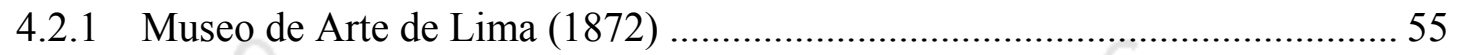

4.2.2 Museo Convento de Santo Domingo - Qorikancha (Cusco) (siglo XVI)...... 57

4.2.3 Museo de Arte Precolombino (Cusco) (siglo XVII) ...................................... 58

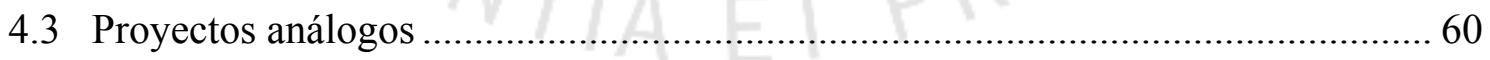

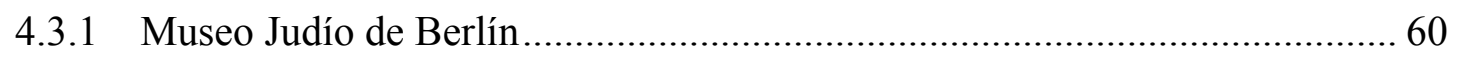

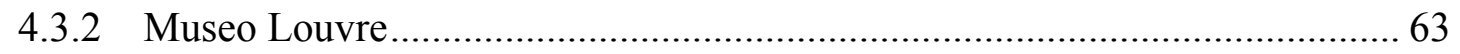

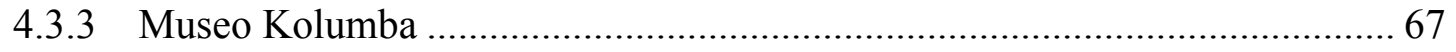

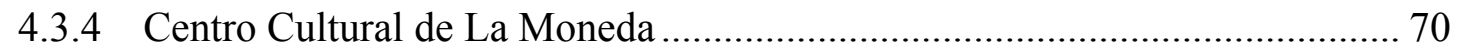

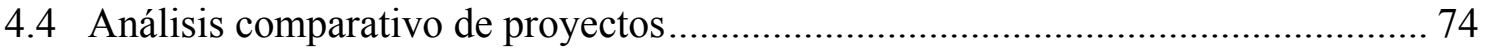

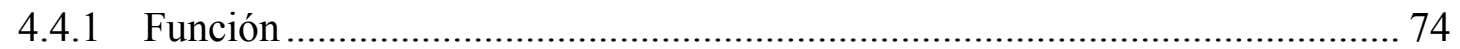

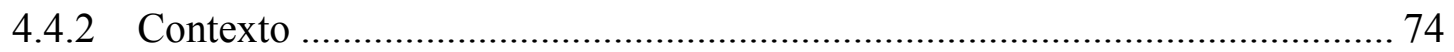




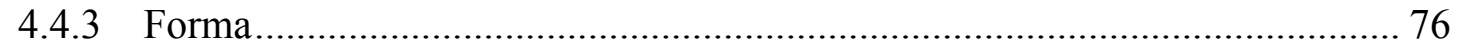

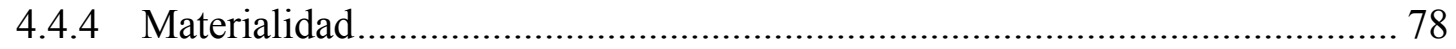

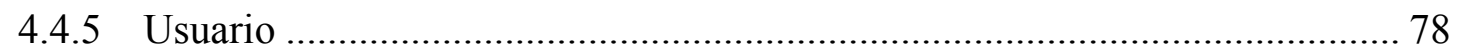

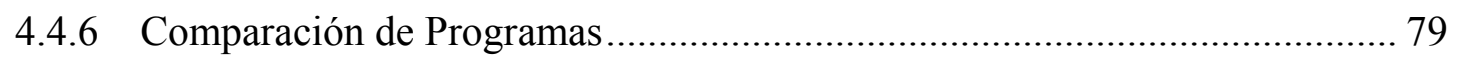

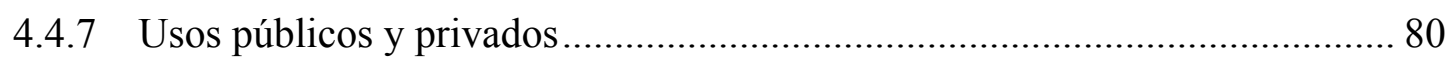

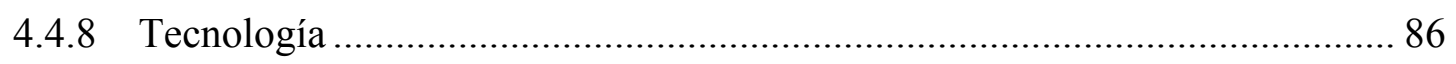

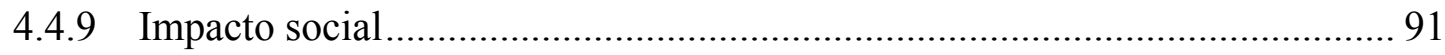

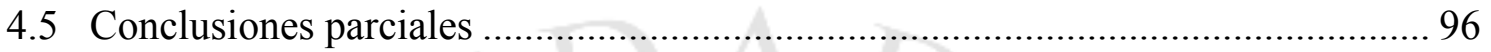

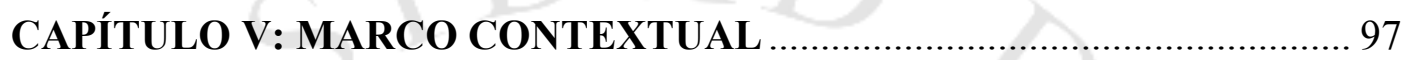

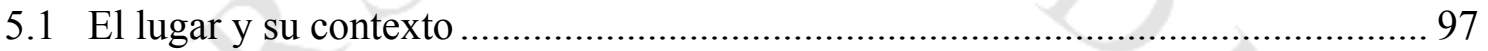

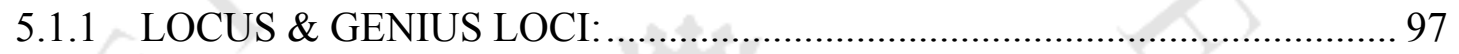

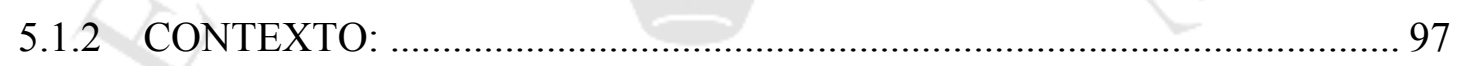

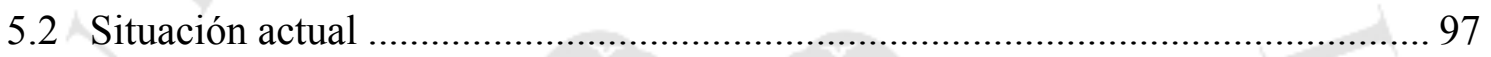

5.2.1 Intervenciones y situación del Parque de la Exposición ................................ 98

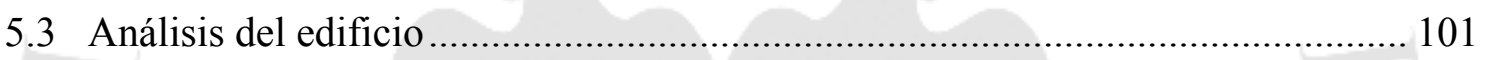

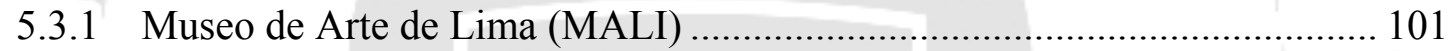

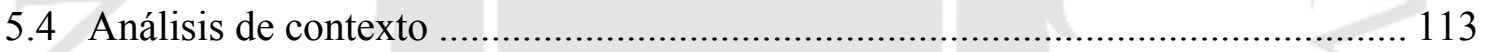

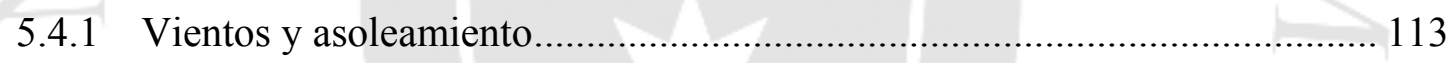

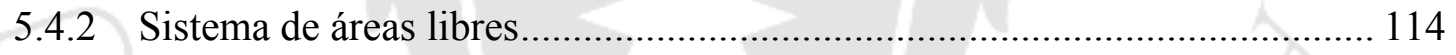

5.4.3 Sistema de cuerpos edificados.............................................................. 115

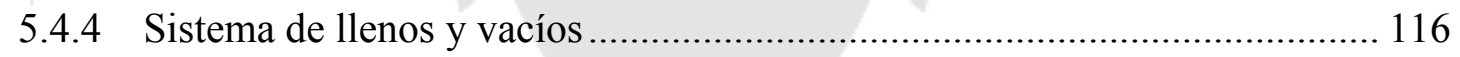

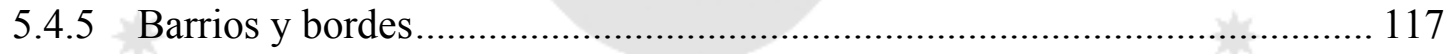

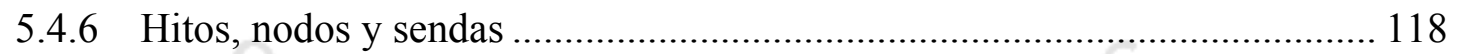

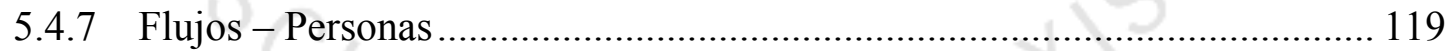

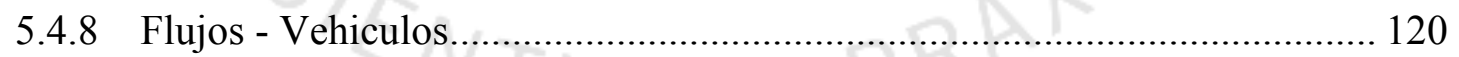

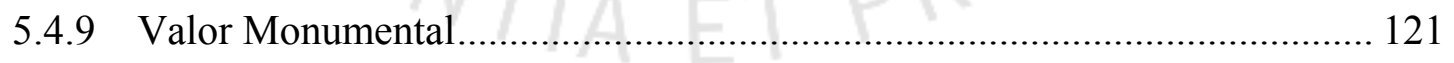

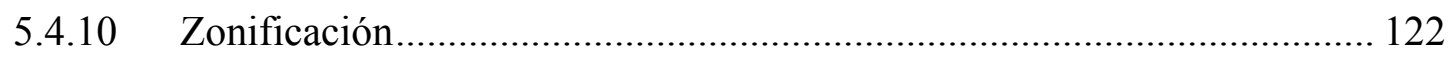

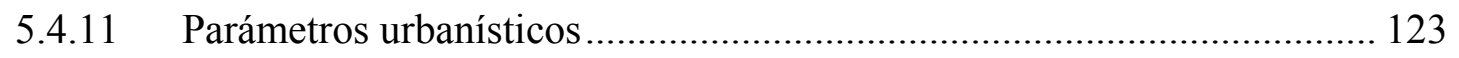

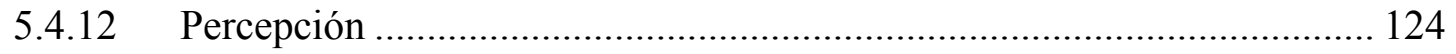

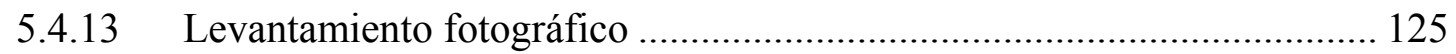

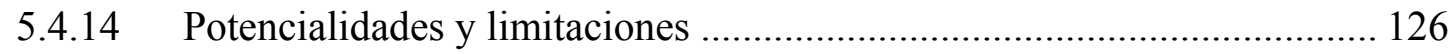

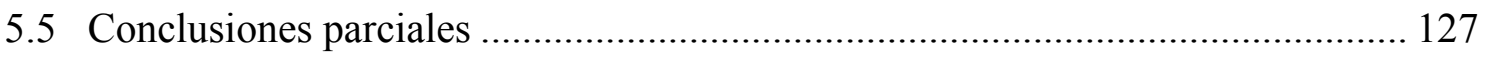


7.1.1 Partido arquitectónico.

7.1.2 La ciudad 133

7.1.3 El entorno - terreno

7.1.4 El usuario

7.1.5 Cálculo de usuarios

7.1.6 Programa general por áreas

7.1.7 Trazado por camino e ingresos

7.1.8 Activación por flujos de usuarios 142

7.1.9 Paisaje y superficies. 143

7.1.10 Cabida con zonificación de áreas por piso ............................................ 147

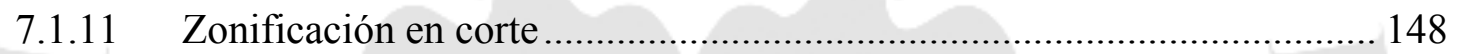

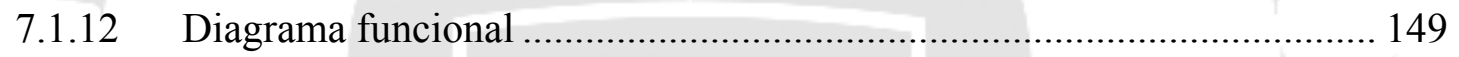

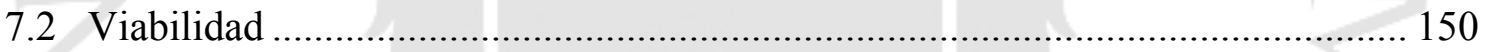

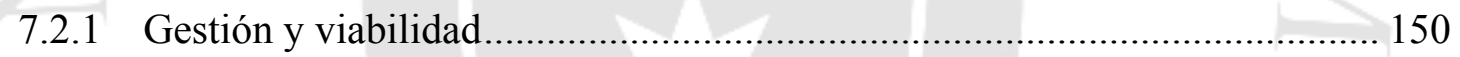

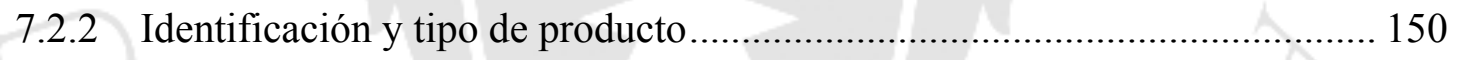

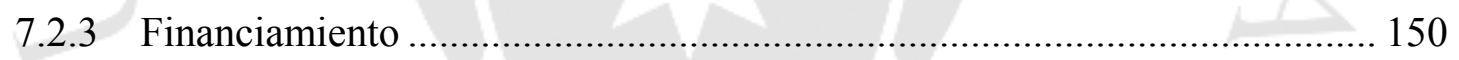

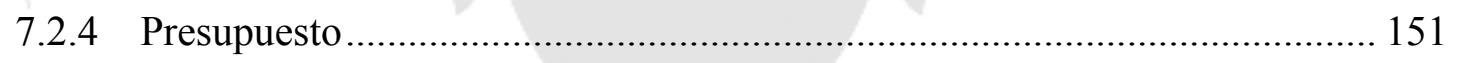

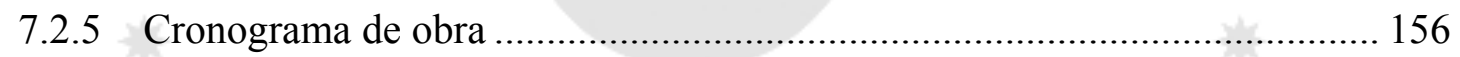

7.3 Cronograma de trabajo de investigación ......................................................... 158

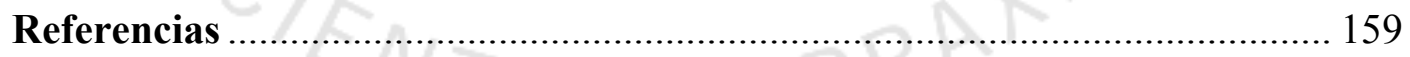

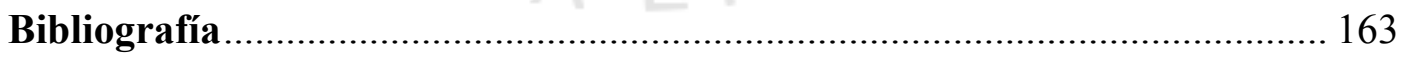




\section{ÍNDICE DE FIGURAS}

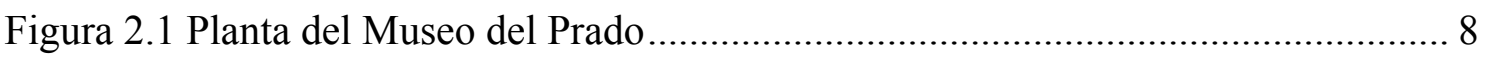

Figura 2.2 Linea de tiempo - Museos de relevancia histórica en el mundo .................... 9

Figura 2.3 Portada del Museo de Nacional de Arqueología, Antropología e Historia... 10

Figura 2.4. Grabado del Palacio de la Exposición 1872 ................................................. 11

Figura 2.5 Vista aérea del Parque de la Exposición en los años 20 ............................. 12

Figura 2.6 Postal del Pabellón Gótico por el centenario de la independecia (1929)...... 12

Figura 2.7 Postal de la Fuente China por el centenario de la independencia (1929)..... 13

Figura 2.8 Museo de la Cultura Peruana, fachada principal, circa 1950 ...................... 13

Figura 2.9. Línea de tiempo - Museos en el Perú ...................................................... 14

Figura 2.10 Principales actividades recreativas, culturales o de esparcimiento realizadas

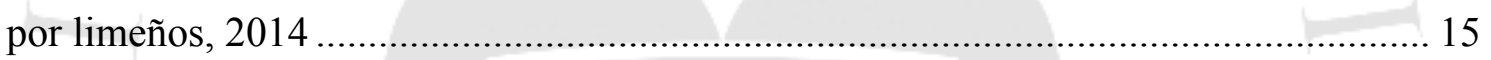

Figura 3.1 Postal del antes y despúes de la intervención de Viollet-Le-Duc en Carcassone

Figura 3.2 Antes y después de intervención de Viollet-Le-Duc en Pierrefonds 19

Figura 3.3 Abadia de Tintern, interior. 20

Figura 3.4 Comparación de la Porta Ticinese en su estado anterior y el posterior a la restauración de Boito 22

Figura 3.5 Intervención de escaleras laterales 23

Figura 3.6 Sala de ingreso con puentes elevados 23

Figura 3.7 Diseño para intervención de los jardines 24

Figura 3.8 Interior de sala de exhibición 24

Figura 3.9 Centro Galego de Arte Contemporaneo (1988), confrontado al Monasterio de Santo Domingo de Bonaval (siglo XIII-XVIII, Santiago de Compsotela, España ........ 26 Figura 3.10 Arq. Karl Friederich Schinkel. Altes Museum (1930), Berlín (Alemania). 27 
Figura 3.11 Arq. Mies Van Der Rohe. Pabellón de Barcelona (1929), Barcelona (España)

Figura 3.12 Arq. Frank Lloyd Wright, Guggenheim Museum (1959), Nueva York (EEUU) 28

Figura 3.13 Arq. Renzo Piano \& Arq. Richard Rogers. Centre Pompidou (1977), Paris (Francia) 29

Figura 3.14 Arq. James Stirling, Neue Staatsgalerie (1984), Stuttgart (Alemania) ....... 29

Figura 3.15 Arq. Steven Holl. Kiasma Museum (1998), Helsinki (Finlandia) 30

Figura 3.16 Arq. Meyer, Scherer \& Rockcastle. Mill City Museum (2004), Minneapolis 30

Figura 3.17 Arq. Paulo David, Centro de Artes (2004), Madeira (Portugal). 31

Figura 3.18 Diagrama de iluminación artificial. 33

Figura 3.19 Esquema de circulaciones 34

Figura 3.20 Sección de museo Cívico de Turín............................................................ 34

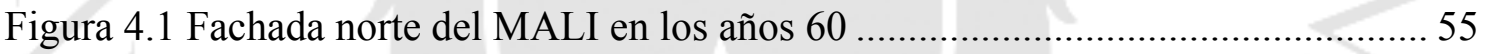

Figura 4.2 Plaza hundida frente a la fachada oeste del MALI .................................... 56

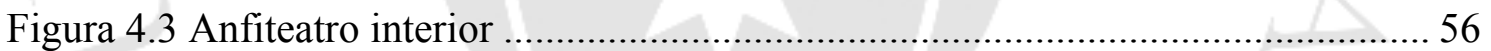

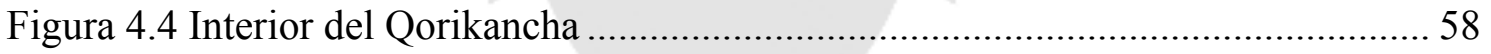

Figura 4.5 Patio central con intervención de estructura metálica.................................59

Figura 4.6 Sala de exhibición en la segunda planta................................................... 61

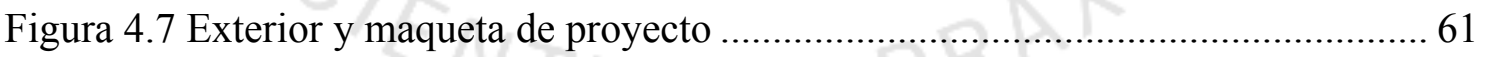

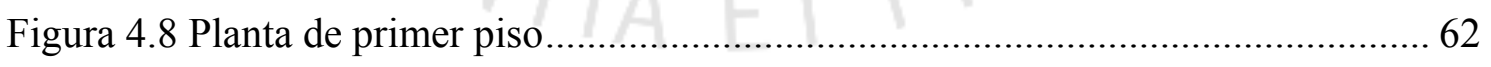

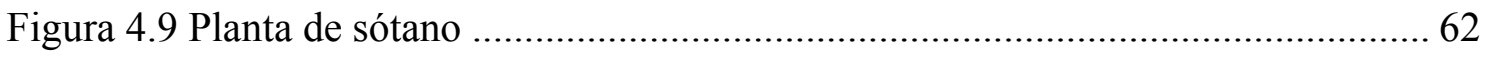

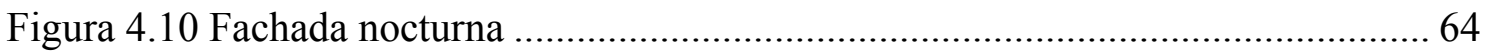

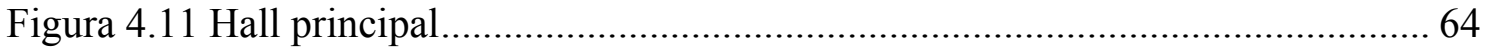

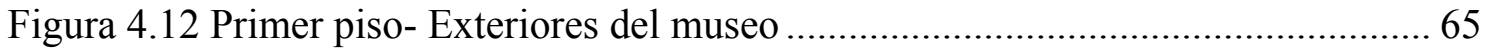

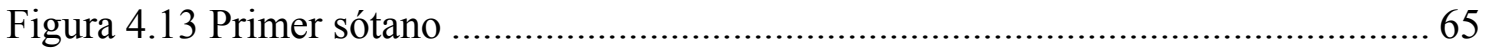


Figura 4.14 Corte transveral del proyecto de Pei

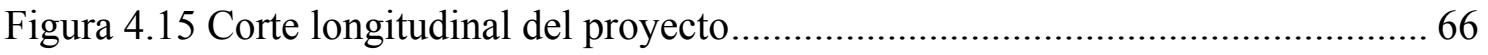

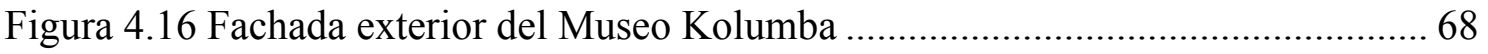

Figura 4.17 Vista interior desde el segundo piso del Museo Kolumba ......................... 68

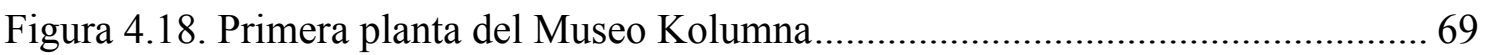

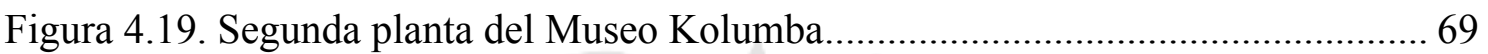

Figura 4.20. Tercera planta del Museo Kolumba. En celeste, las partes privadas. ....... 69

Figura 4.21 Vista exterior del Centro Cultural de la Moneda ...................................... 71

Figura 4.22 Corte esquemático del Centro Cultural de la Moneda .............................. 71

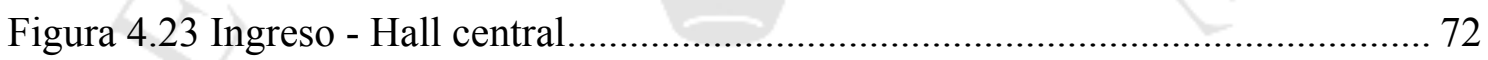

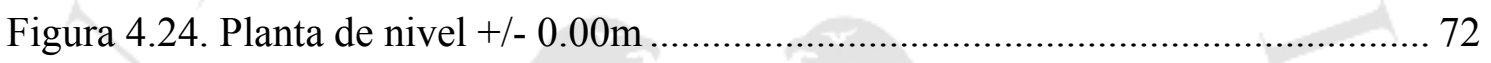

Figura 4.25. Sótano 1 esquemático del Centro Cultural de la Moneda ......................... 72

Figura 4.26. Sótano 2 esquemático del Centro Cultural de la Moneda ......................... 73

Figura 4.27. Sótano 3 esquemático del Centro Cultural de la Moneda ......................... 73

Figura 4.28 Emplazamiento del Museo Judío de Berlín .............................................. 74

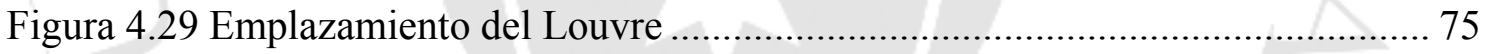

Figura 4.30 Emplazamiento del Museo de Kolumba .................................................. 75

Figura 4.31 Emplazamiento del Centro Cultural del Palacio de la Moneda .................. 76

Figura 4.32 Comparación de área de influencia y recorridos........................................ 77

Figura 4.33 Esquema de áreas públicas y semipúblicas del Museo Judío de Berlín...... 80

Figura 4.34 Esquema de planta de nivel 1 - Museo del Louvre .................................... 81

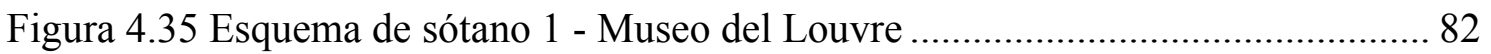

Figura 4.36 Plantas esquemáticas del museo de Kolumba ............................................. 83

Figura 4.37 Esquemas primer sótano de Centro Cultural de la Moneda........................ 84

Figura 4.38 Esquema de segundo sótano del Centro Cultural de la Moneda................. 85

Figura 4.39 Esquema de tercer sótano del Centro Cultural de la Moneda ...................... 85 
Figura 4.40 Fachada del Museo de Kolumna.....

Figura 4.41 Detalle esquemáticode pilotes del Museo de Kolumba ..... 87

Figura 4.42 Detalle de araña en encuentro perpendicular 87

Figura 4.43. Detalle de araña de acero simple 88

Figura 4.44. Vista de las arañas y cables de acero 88

Figura 4.45 Axonometría de niveles de vigas principales 89

Figura 4.46 Corte esquemático de rampas.

Figura 4.47 Barras de alucobón atraviesan de lado a lado las paredes de concreto del Museo Judío de Berlín. 89

Figura 4.48 Interior del museo todo recubierto en alucobón 90

Figura 5.1 Ampliación de la Av. Wilson en los años 50. 99

Figura 5.2 Construcción de la vía expresa de Paseo de la República (primer tramo) .... 99

Figura 5.3 Vista del Parque de la Exposición desde el Museo Metropolitano.............. 100

Figura 5.4 Vista de lago japonés y anfiteatro del Parque de la Exposición ................. 100

Figura 5.5 Zonificación del museo y alrededores.................................................. 102

Figura 5.6 Vías y límites de Parque de la Exposición .................................................... 103

Figura 5.7 Axonometría de programa actual del MALI............................................... 104

Figura 5.8 Plano de circulación de la primera planta ............................................... 105

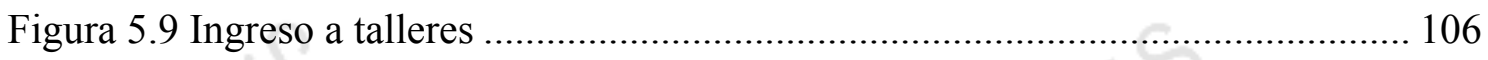

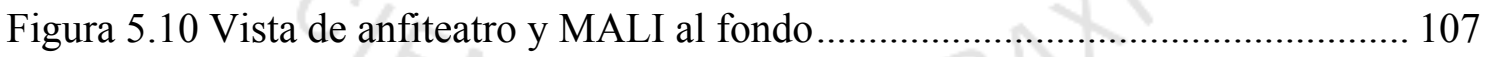

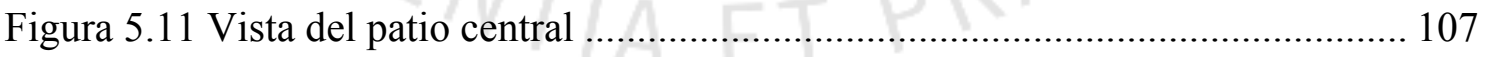

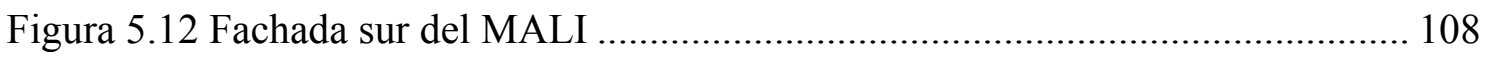

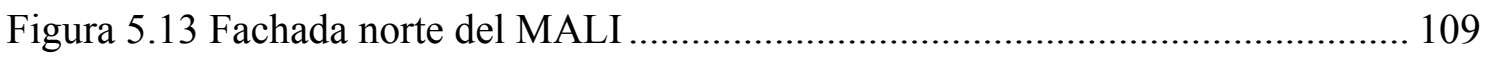

Figura 5.14 Elevación sur y elevación oeste ......................................................... 109

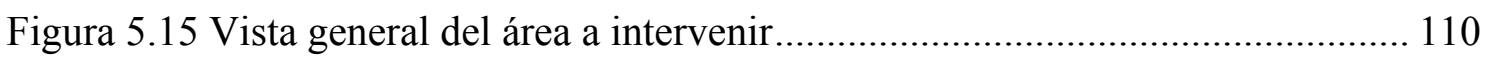

Figura 5.16 Detalles de columna metálica.......................................................... 110 
Figura 5.17 Tipos de piso

Figura 7.1 Imagen de los jardines del Parque de la Exposición, 1872 135

Figura 7.2. Plano del Parque de la Exposición, 1904 136

Figura 7.3. Fotografía aérea de la zona, circa 1930 136

Figura 7.4. Vista de la esquina de la Av. Wilson y Paseo Colón actualmente 144

Figura 7.5 Isometría de techo verde 145

Figura 7.6 Características del sistema de riego por goteo 146 


\section{ÍNDICE DE ILUSTRACIONES}

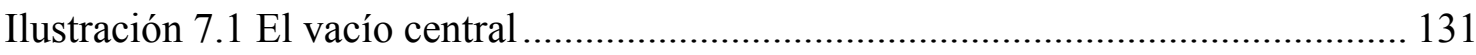

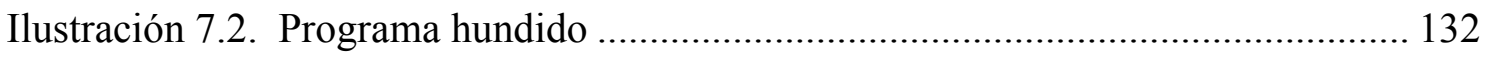

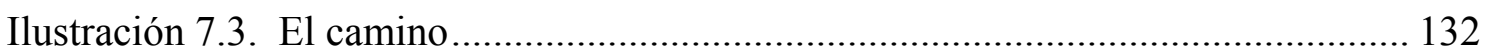

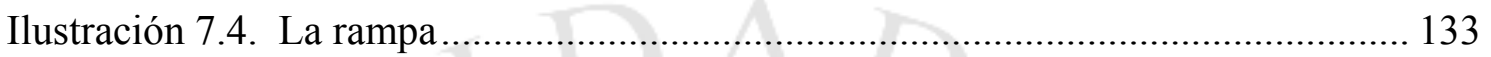

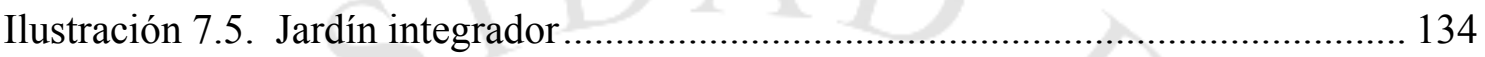

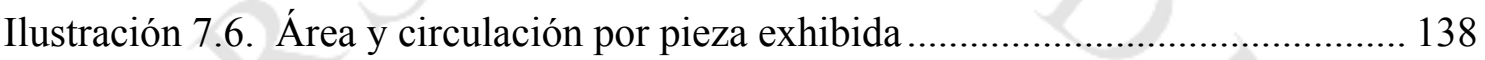

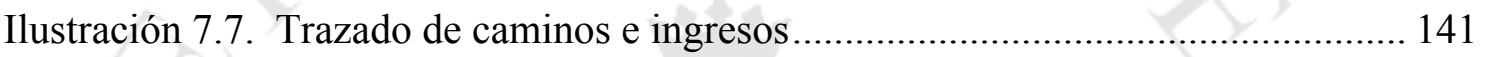

Ilustración 7.8. Activación por flujos de usuarios ................................................. 142

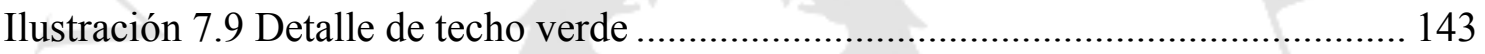

Ilustración 7.10 Corte de paisaje de nivel +/- 0.00 de sección de parque con proyecto

Ilustración 7.11 Corte de paisaje de nivel +/- 0.00 de sección de ampliación del MALI

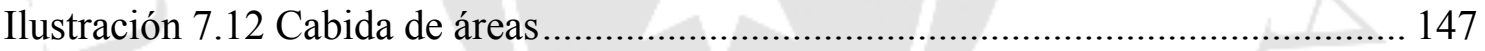

Ilustración 7.13 Corte esquemático longitudinal X................................................ 148

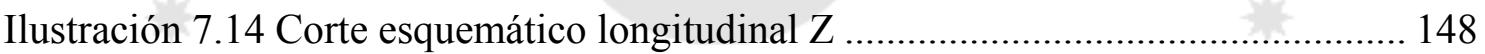

Ilustración 7.15 Corte esquemático transversal Y ................................................. 149 


\section{ÍNDICE DE DIAGRAMAS}

Diagrama 3.1. Diagrama de ángulos de visión de obras de arte.................................... 33

Diagrama 3.2 Proceso museográfico, movimientos, y planeación ................................ 46

Diagrama 3.3 Diagrama general de museos ......................................................... 48

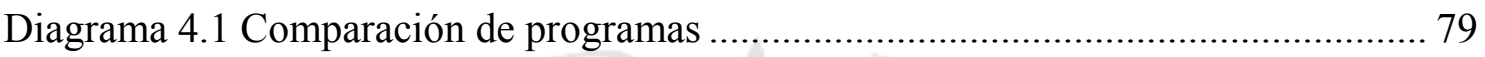

Diagrama 7.1 Diagrama de programa funcional ................................................... 149

Diagrama 7.2 Cronograma de trabajo de investigación ......................................... 158 


\section{ÍNDICE DE TABLAS}

Tabla 2.1 Estadísticas de visitantes nacionales y extranjeros...................................... 16

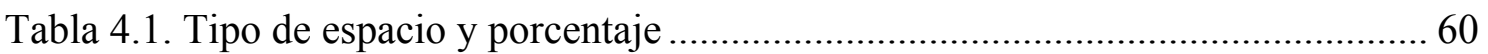

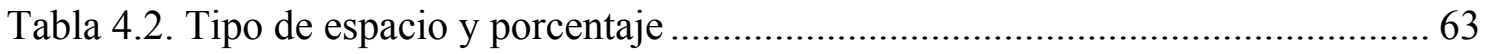

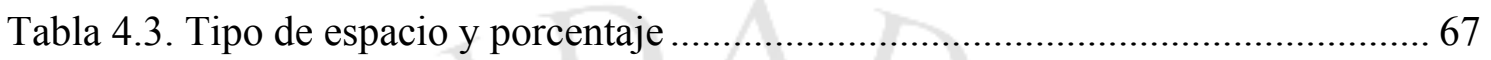

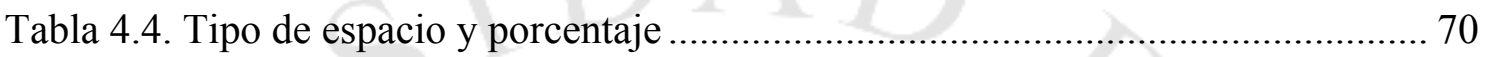

Tabla 4.5 Comparación de proyectos de referencia - Museo Judío de Berlín ................ 92

Tabla 4.6 Comparación de proyectos de referencia - Museo de Louvre (ampliación de Pei)

Tabla 4.7 Comparación de proyectos de referencia - Museo de Kolumba..................... 94

Tabla 4.8 Comparación de proyectos de referencia - Centro Cultural de La Moneda... 95

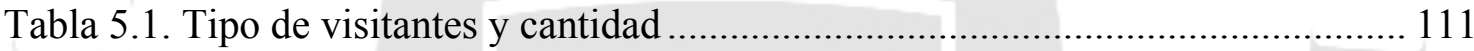

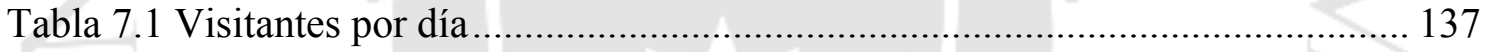

Tabla 7.2 Proyección de visitantes hacia el año 2027 .............................................. 138

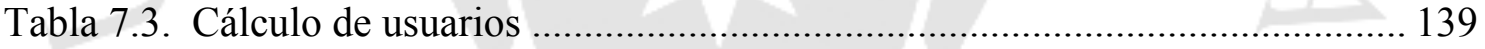

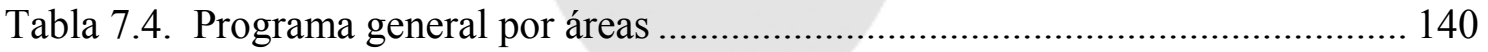

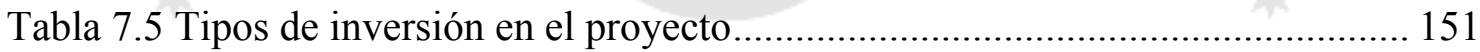

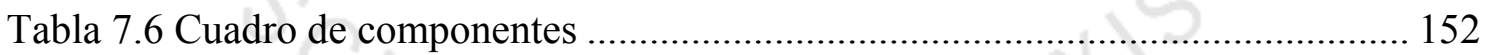

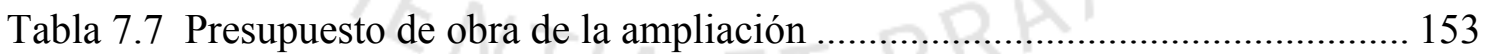

Tabla 7.8 Presupuesto de obra de los estacionamientos ............................................ 154

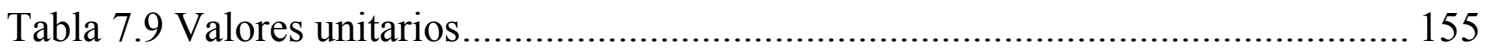

Tabla 7.10 Cuadro de ejecución de obra y cciones complementarias ......................... 157 


\section{ÍNDICE DE LÁMINAS}

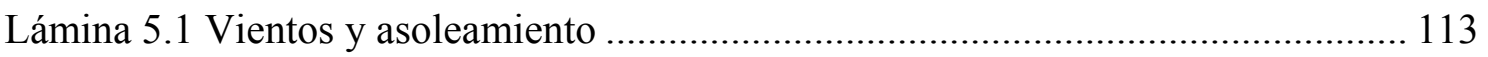

Lámina 5.2 Sistema de áreas libres ...................................................................... 114

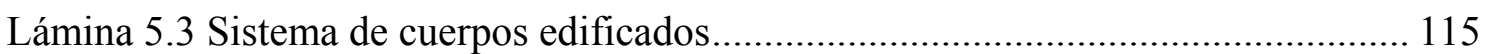

Lámina 5.4 Sistema de llenos y vacíos..................................................................... 116

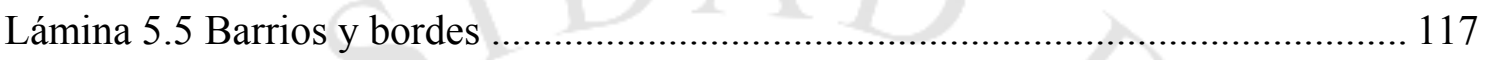

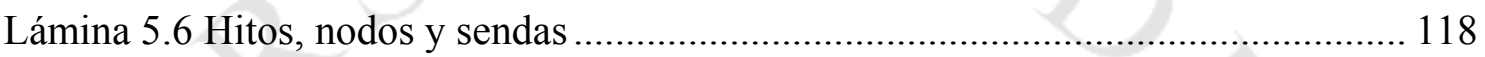

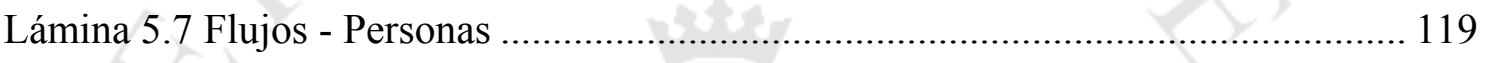

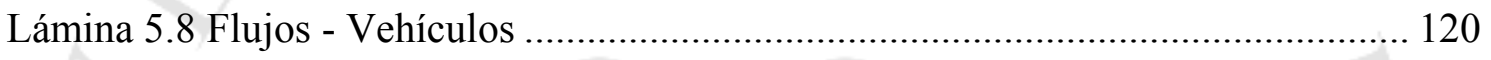

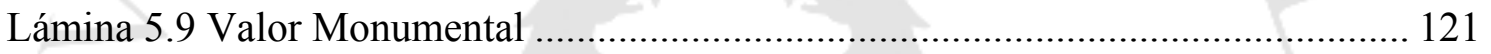

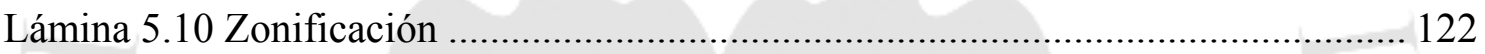

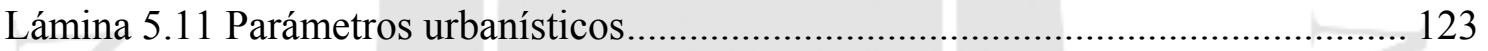

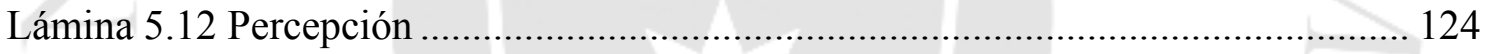

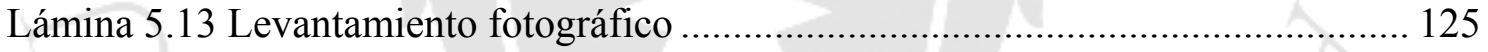

Lámina 5.14 Potencialidades y limitaciones ............................................................ 126 


\section{INTRODUCCIÓN}

El crecimiento de las ciudades cada vez se vuelve más rápido, envolviendo así a los centros históricos dentro de grandes metrópolis con millones de habitantes. Esto hace indispensable una política de intervención y recuperación de edificios históricos en un contexto monumental histórico.

Usualmente se tiende a utilizar estos predios con fines comerciales para así dinamizar el lugar; sin embargo, también se recuperan edificios con fines culturales y artísticos, para convertirlos en galerías o museos, y además enriquecer el espacio público.

En la actualidad, se pueden encontrar ejemplos alrededor del mundo en los que se ha recuperado un edificio histórico, de gran importancia para la ciudad y se ha intervenido el lugar circundante para así generar más espacios con diversas funciones y activar toda el área.

En el caso específico de la ciudad de Lima, existen casos que tienen gran potencial, como el Parque de la Exposición, que se encuentra en la entrada sur del Centro Histórico y que a su vez contiene diversos monumentos y edificios de carácter patrimonial, entre ellos, el Museo de Arte de Lima. Este predio tiene un plan de expansión al lado oeste del edificio principal, zona que compromete parte del parque y otros monumentos históricos, por lo que impacto que tendrá esta ampliación debe ser positivo para el entorno y aportar un nuevo espacio a la ciudad.

Esta investigación tiene como objetivo principal explorar y definir los lineamientos de las intervenciones contemporáneas en edificios históricos, y servir de guía para la elaboración de un programa de ampliación para el Museo de Arte de Lima. 


\section{CAPITULO I: GENERALIDADES}

\subsection{Tema}

Ampliación del Museo de Arte de Lima a través de la proyección de un Centro Cultural subterráneo en el espacio urbano comprendido dentro del Parque de la Exposición, el edificio, y las avenidas Paseo Colón y Wilson.

\subsection{Justificación del tema}

El Museo de Arte de Lima tiene un déficit de $1500 \mathrm{~m}^{2}$ de área expositiva permanente, y de $1200 \mathrm{~m}^{2}$ de área de almacenaje (Gerencia MALI, 2016); ambos problemas deben ser resueltos cuanto antes. El comité de adquisición de obras sigue obteniendo nuevas piezas y cada vez es más costoso el almacenaje de las mismas, ya que los depósitos son alquilados y se encuentran al sur de la ciudad.

Por otro lado, en la actualidad, el MALI recibe 250 visitantes diarios en promedio por sus exposiciones, y unos 200 más para sus talleres de arte (Gerencia MALI, 2016), lo que suma un total de 450 visitantes. Dicha institución proyecta que debe duplicar sus visitantes, y aumentar sus asistentes a talleres, para así llegar a un total de 1000 personas diarias en el museo (adicionalmente al personal administrativo y docente). Esto permitirá aumentar los ingresos económicos con lo que se podrá financiar y mejorar las exposiciones futuras.

\subsection{Planteamiento del problema}

¿Cómo se debería proyectar la ampliación del Museo de Arte de Lima para que se convierta en un activador cultural y social en la ciudad?

El Museo de Arte de Lima es el único que reúne una colección de arte que engloba las distintas etapas históricas del Perú, desde la era precolombina, hasta la república. Sin embargo, gran parte de estas piezas están actualmente almacenadas en los depósitos de dicha institución por falta de espacio. Es necesario, en consecuencia, ampliar el museo para poder exhibir estas obras y contar con nuevos depósitos integrados que faciliten su traslado, almacenaje y exhibición. El nuevo edificio debe resolver, a su vez, los problemas de entorno y de falta de espacio público de esta zona de la ciudad, sin afectar la monumentalidad del Palacio de la Exposición ni la del parque. 


\subsection{Objetivos}

\subsubsection{General}

Realizar una investigación que permita extraer referencias y pautas para la recuperación, ampliación arquitectónica y puesta en valor del local del Museo de Arte de Lima (MALI).

\subsubsection{Específicos}

a. Investigar los antecedentes de museos en el mundo y en el Perú, y considerar también el contexto en el que se encuentran para poder contar con una visión general de la situación.

b. Analizar las teorías y conceptos respecto a intervenciones y restauraciones en edificios de carácter patrimonial para entender cómo se debe recuperar un edificio histórico dentro de un contexto monumental.

c. Encontrar y analizar proyectos análogos al tema de museos que puedan servir como referentes para sustentar la hipótesis planteada. Además, procesar las encuestas sobre las preferencias de la población que acude al MALI y a este espacio público en el Parque de la Exposición para poder elaborar un programa de necesidades básicas.

d. Evaluar la situación actual del Museo de Arte de Lima y su contexto, y determinar cuáles serán las tomas de partida para la ampliación subterránea del edificio.

\subsection{Hipótesis del trabajo}

Si se diseña la ampliación del Museo de Arte de Lima considerando los requerimientos y la ubicación en el centro histórico entonces, se podrá resolver el traslado, almacenamiento y exposición de las piezas.

\subsection{Alcances y limitaciones}

\subsubsection{De la investigación}

\section{Alcances}

a. La investigación histórica se centrará en la historia de la aparición de los museos en el Perú y adicionalmente se mencionarán solo algunos hitos importantes en el mundo. Esto debe incluir un contexto espacial y temporal inmediato. 
b. Se analizarán teorías de arquitectos e historiadores europeos del siglo XIX y XX, que sirvieron para moldear nuestra visión actual de la intervención arquitectónica.

c. Los proyectos análogos serán edificios históricos que han sido intervenidos con arquitectura contemporánea para adaptarlos a un uso museal o cultural.

\section{Limitaciones}

d. El área a investigar y analizar será Parque de la Exposición; puntualmente sólo se trabajará el contexto inmediato del Palacio de la Exposición.

e. La información recolectada para el Marco Operativo acerca de datos demográficos será únicamente a través encuestas previamente procesadas por terceros.

f. Además, dentro del mismo marco, la información sobre museos y otros referentes, será realizada a través medios escritos y digitales. No habrá levantamiento de información in-situ.

\subsection{Del proyecto}

\section{Alcances}

g. El proyecto intervendrá el nivel 0 (calle) frente a la fachada este y oeste del museo, y servirá de elemento integrador entre la ampliación y el Palacio de la Exposición.

h. La ampliación debe ser accesible para personas con discapacidad, así como tener accesos y montacargas especiales para las obras que deberán tener áreas especiales de exposición y así como de almacenaje.

\section{Limitaciones}

i. El programa de la futura ampliación se centrará únicamente en las necesidades del museo, así como en mejorar y poner en valor el área urbana que le concierne.

j. El futuro edificio no podrá elevarse sobre el nivel 0 para respetar la monumentalidad del Palacio de la Exposición. El estacionamiento deberá tener las mismas características subterráneas y ser adecuado para el nuevo aforo de la ampliación.

k. No se intervendrán las vías carrozables ni el resto del parque. 


\subsection{Diseño de la investigación}

El tipo de investigación a realizar será principalmente descriptivo, ya que se analizarán casos análogos de museos en el mundo, como el Museo Judío de Berlín, o el Centro Cultural de la Moneda en Santiago.

También se realizará un análisis exhaustivo del entorno urbano del Palacio de la Exposición y del edificio en sí.

Asimismo, se hará una revisión de los hitos en la evolución histórica de espacios expositivos en el mundo y el Perú. También se investigarán teorías de intervención y ampliación de espacios con valor monumental.

Con toda la información obtenida, se buscará definir tendencias y soluciones arquitectónicas para poder aplicarlas en el diseño final del proyecto. El análisis del programa y la proporción entre las partes del sistema también será de vital importancia para la futura ampliación.

\subsection{Metodología de la investigación}

\subsubsection{Forma de consulta de información}

La información que será presentada proviene de libros, bibliotecas, mediatecas y de bases de datos científicas. Se consultarán fuentes especializadas en arquitectura expositiva y normativa de intervención monumental en general. También, se contará con fuentes de primarias, obtenidas a través en entrevistas o consultas directas. Además, se realizarán visitas al lugar en cuestión, así como a casos análogos en otros contextos.

\subsubsection{Forma de recopilación de la información}

La información recopilada proviene de medios físicos, así como de medios digitales. Las fuentes son de origen local, así como extranjero. Toda la información será verificada y deberá venir exclusivamente de sitios o fuentes oficiales para poder ser dada como válida.

\subsubsection{Forma de análisis de la información}

Se sintetizará la información recopilada a través de líneas de tiempo, tablas, análisis gráficos (láminas de análisis) y de planimetría. 


\subsubsection{Forma de presentación de la información}

La información será presentada por escrito, estructurada por capítulos y detallada en una tabla de contenido, tabla de ilustraciones e índice de tablas. Se incluirán anexos a manera de planos de la propuesta arquitectónica, así como textos de normativa y reglamento pertinente a la investigación. Las referencias y bibliografía serán presentadas en sistema APA. 


\section{CAPÍTULO II: MARCO REFERENCIAL}

\subsection{Antecedentes}

Para empezar, se analizará la evolución de los museos desde las colecciones privadas del Vaticano en el renacimiento, el nacimiento de salas expositivas, los cambios a través del tiempo y finalmente su concepción actual.

\subsection{Museos en el Mundo}

La colección de arte empieza desde el renacimiento, con la muestra y exposición de arte clásico de la antigüedad y arte contemporáneo de la época. El referente más antiguo que se tiene data de principios del siglo XVI y es un espacio en el Vaticano diseñado por Bramante $^{1}$ al aire libre para exponer dos famosas estatuas: Apolo Belvedere y Laocoonte. Este espacio adjunto al Pabellón de Inocencio VIII, fue adaptado al nuevo uso expositivo, convirtiéndose así en la primera "sala" de contemplación construida específicamente para este uso. (Pevsner, 1979)

Es entonces que empieza una tendencia en Europa, especialmente en Italia, de diseñar y construir espacios dedicados para exhibir piezas de arte. Esto por supuesto era exclusivo de las clases más acomodadas que podían permitirse coleccionar este tipo de artefactos.

Más adelante, a mediados del siglo XVIII, el Conde Algarotti ${ }^{2}$, por encargo de Augusto III de Dresde, diseña por primera vez un edificio independiente (de palacios, conventos o casas de nobles) para exponer estas atesoradas piezas de arte y que el público pueda acceder a ellas dentro de un horario específico. Esto llevaría, años más tarde, y con las ideas de la Ilustración, a la preocupación por la correcta iluminación de estos nuevos "museos" y a pensar en la circulación dentro de los mismos; según el ideal que se mantuvo por casi 200 años, debía existir una continuidad lineal, pero al mismo tiempo un cruce, para que el individuo pudiese moverse o "saltar" partes del recorrido a libre albedrio. (Arion \& Lungu, n.d.)

\footnotetext{
${ }^{1}$ Donato Bramante: arquitecto italiano del Renacimiento (1444 - 11 de marzo de 1514). Es reconocido por su plan para la Basílica de San Pedro.

${ }^{2}$ Francesco Algarotti: escritor y coleccionista italiano (Venecia, 11 de diciembre de 1712 - Pisa , 3 de mayo de 1764). Tiene gran influencia sobre la arquitectura neoclásica al recoger ideas de predecesores.
} 
Figura 2.1

Planta del Museo del Prado

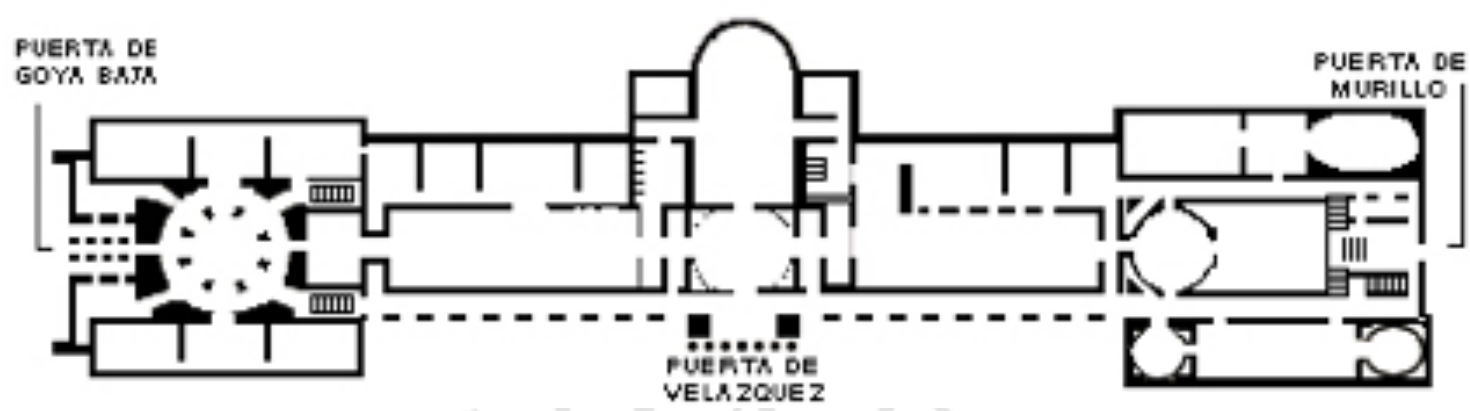

Fuente: Patrimonio Arquitectónico de Asturias, 2015. Museo del Prado. Recuperado de https://goo.gl/d4yDVG

Durante este periodo que es de exploración "museal", se crean diversas categorías de museos: los nacionales, los especializados, los generales y territoriales, los de sitio, los que están al aire libre, los de trabajo y los virtuales.

Finalmente, ya en el siglo XX, y luego de las devastadoras guerras, se busca generar nuevos espacios y dar un nuevo uso a edificios e inclusive barrios enteros que han sido destruidos o que necesitan atraer de nuevo a la gente. Para eso, los gobiernos locales (ya no sólo los dueños de las colecciones de arte), empiezan a localizar posibles lugares donde se puedan crear focos de cultura para generar identidad y dinamizar la zona. En algunos casos pueden ser espacios dentro del casco antiguo urbano de las ciudades, como edificios abandonados, o en parques que fungen de pulmón verde para la ciudad que necesitan tener algún nodo articulador. 


\subsubsection{Línea de tiempo - Museos de relevancia histórica en el mundo}

Figura 2.2

Linea de tiempo - Museos de relevancia histórica en el mundo

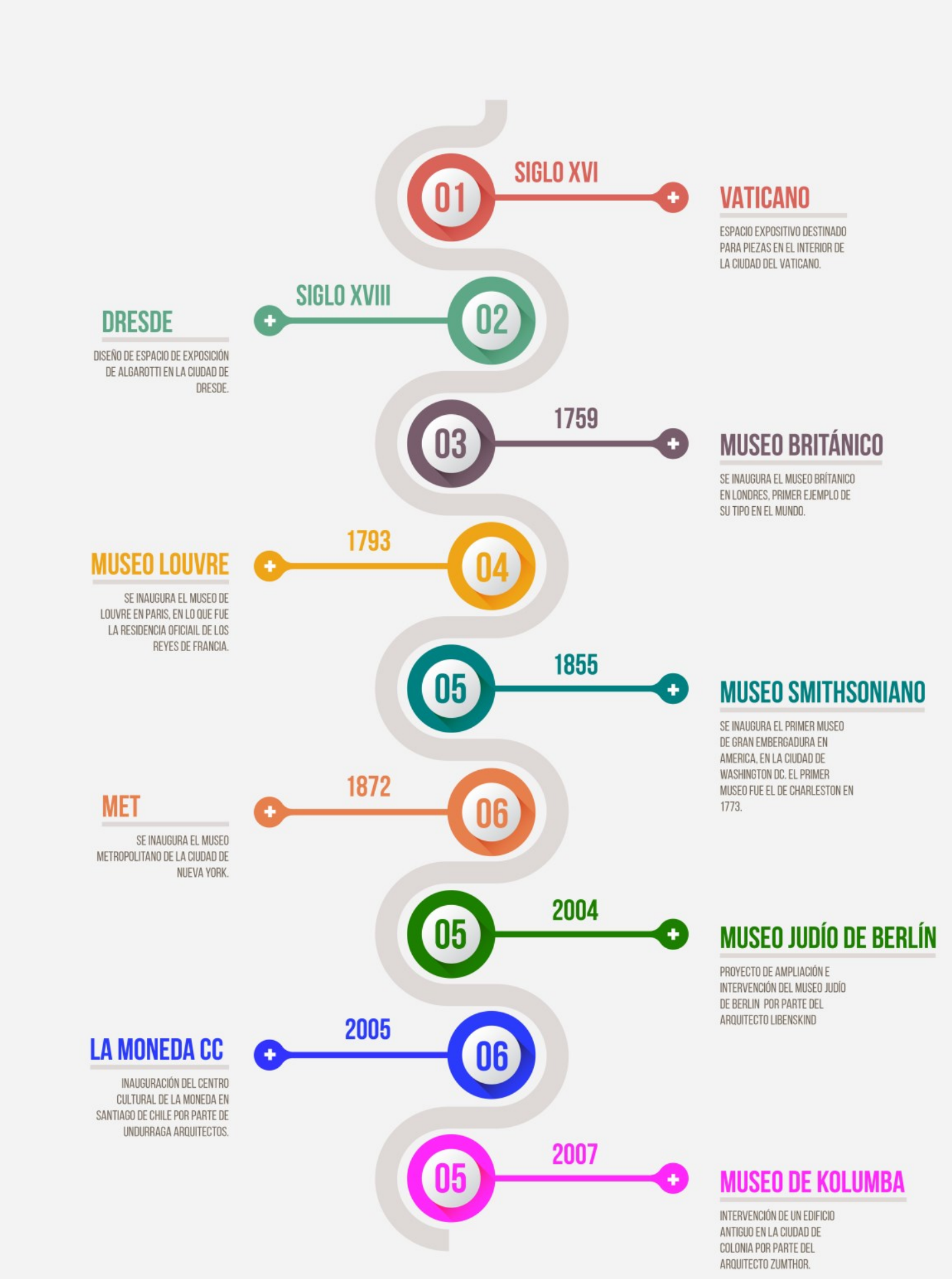

Nota: Linea de tiempo elaborada con los museos de mayor importancia histórica en el mundo.

Fuente: Elaboración propia, 2017 


\subsection{Museos en el Perú}

En el caso del Perú, el museo más antiguo data del siglo XIX: el Museo Nacional de Arqueología, Antropología e Historia del Perú. Fundado en 1822 por José Bernardo de Torre Tagle, Bernardo de Monteagudo y Mariano de Rivero y Ustariz. Este espacio buscaba poner en valor la herencia cultural del país recientemente independiente de España y que hasta el día de hoy está tratando de construir una identidad.

Figura 2.3

Portada del Museo de Nacional de Arqueología, Antropología e Historia

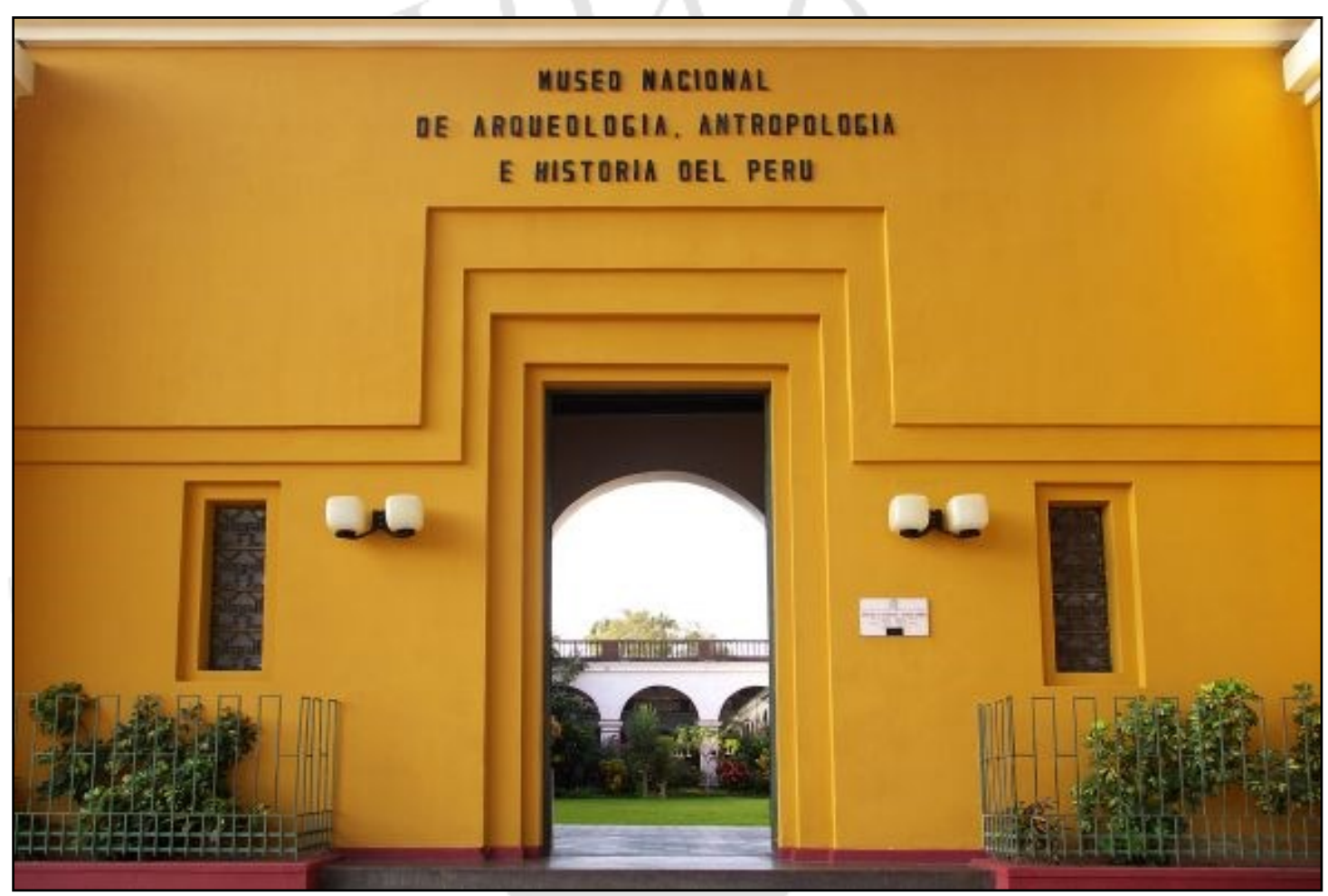

Nota: Foto de fachada actual, con ingreso abierto.

Fuente: Fenix News, 2015. Museo Nacional de Arqueología, Antropología e Historia del Perú. Recuperado de https://goo.gl/hFA7Ml

Luego, en julio de 1872 se inaugura el Palacio de la Exposición en el parque del mismo nombre con motivo de la "Gran Muestra de Artes, Ciencias e Industrias" durante el gobierno del Presidente Balta. Más adelante este edificio tuvo diversos usos, desde Ministerio, hasta cuartel de guerra, pasando por Senado y sede Municipal. En la actualidad es el la sede del Patronato de las Artes desde 1956 (Archivo MALI, 2015) y, en consecuencia, del Museo de Arte de Lima, que reune una importante colección de arte de varios periodos de la historia del Perú que por el momento está esperando ser expuesto ya que el edificio se encuentra en remodelación. 
Figura 2.4.

Grabado del Palacio de la Exposición, 1872

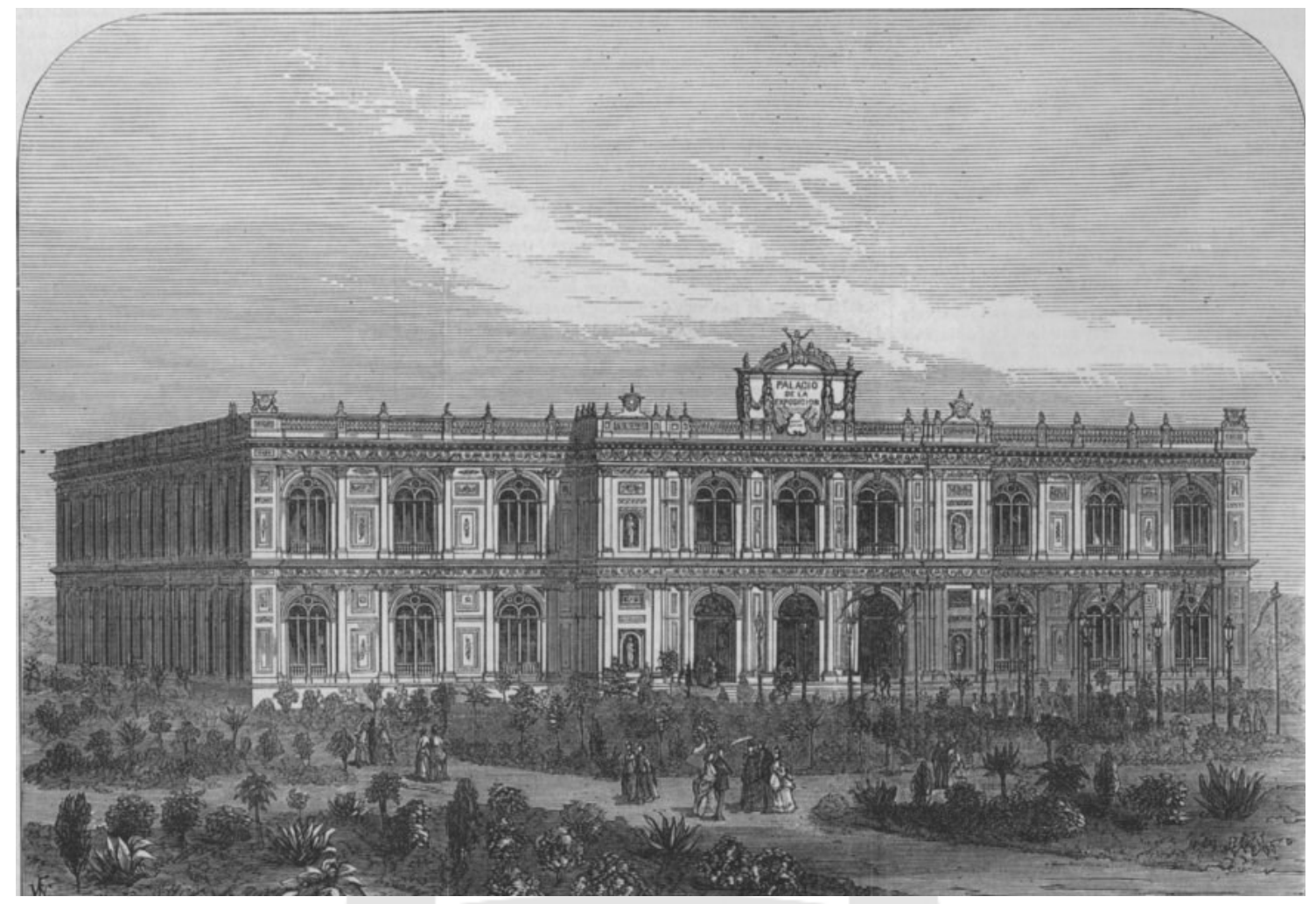

Fuente: Perú Siglo XIX, 2013. Palacio de la Exposición. Recuperado de https://goo.gl/F0UYVe

El diseño del edifcio estuvo a cargo de Antonio Leonardi ${ }^{3}$ y la elaboración de sus piezas en acero fue encomendada a la Casa Eiffel. Su construcción se dio sobre un área de $4320 \mathrm{~m}^{2}$ en lo que luego se conocería como el Parque de la Exposición ${ }^{4}$. El estilo es típico de la arquitectura neorenacentista. ${ }^{5}$ Cuenta con dos plantas y un patio central, con una estructura metálica de planta libre y alturas interiores de $5 \mathrm{~m}$ por piso. Además, posee cuatro ingresos, y originalmente el principal estaba orientado al norte. En 1898 se construye la avenida Colón justo frente a esa entrada. Actualmente esta se encuentra cerrada y el ingreso de visitantes es por el sur, desde el parque.

El edificio se inspira en el Palacio de Versailles, Francia y el Palacio Vendramin, Italia.

\footnotetext{
${ }^{3}$ Antonio Leonardi: arquitecto italiano reconocido por su colaboración para la elaboración de edificios y jardines para la conmemoración de los 50 años de la independencia del Perú bajo el mandando del Presidente Balta.

${ }^{4}$ Parque de la Exposición: Jardín histórico monumental mandado a construir entre 1870 y 1872 por el Presidente Balta para la conmemoración de los 50 años de la independencia del Perú.

${ }^{5}$ Neorenacentista: arquitectura basada en los valores y la estética del renacimiento; fue contemporánea e influenciada por el neobarroco.
} 
Figura 2.5

Vista aérea del Parque de la Exposición

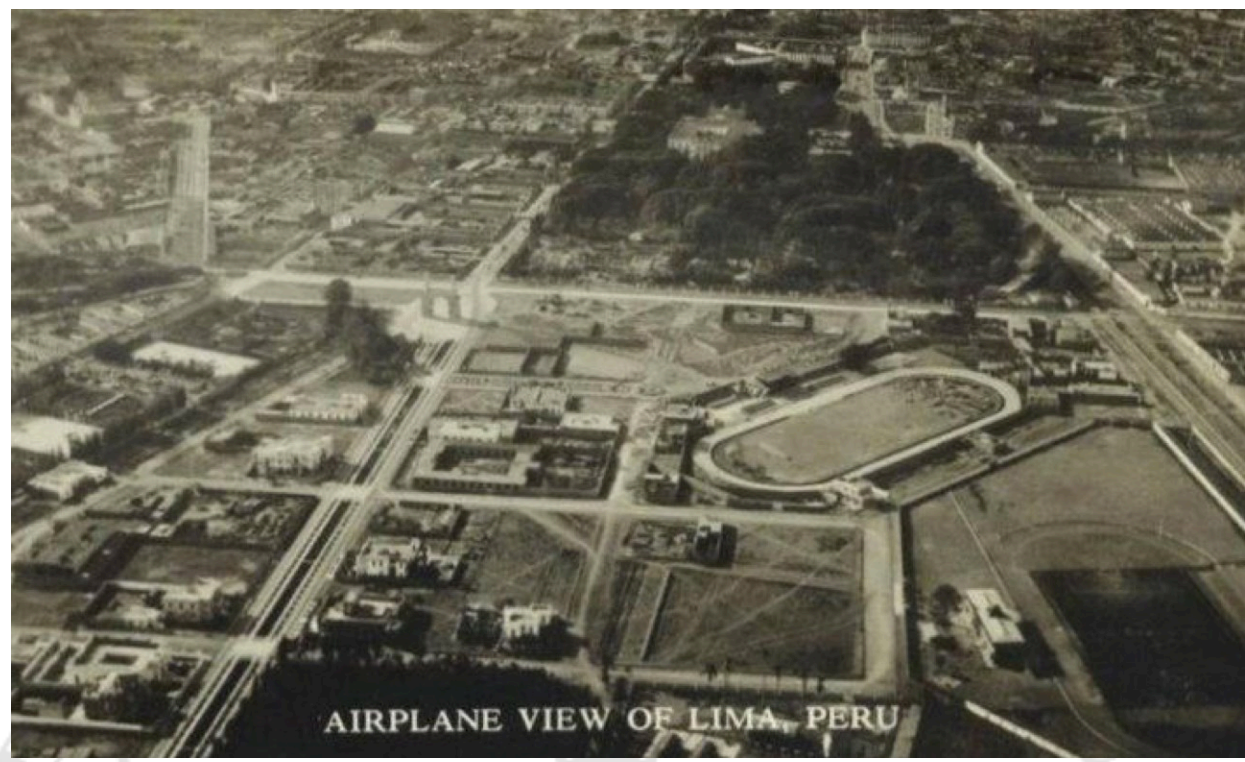

Nota: Vista aérea del Parque de la Exposición y Estadio Nacional en los años 20

Fuente: Lima La Única, 2014. Lima Aérea. Recuperado de https://goo.gl/VQoC8a

El Parque de la Exposición es considerado un Jardín Histórico y ambiente patrimonial, por lo que todos los edificios y esculturas en su interior son considerados "de interés monumental" $"$.

Figura 2.6

Postal del Pabellón Gótico por el centenario de la independencia (1929)
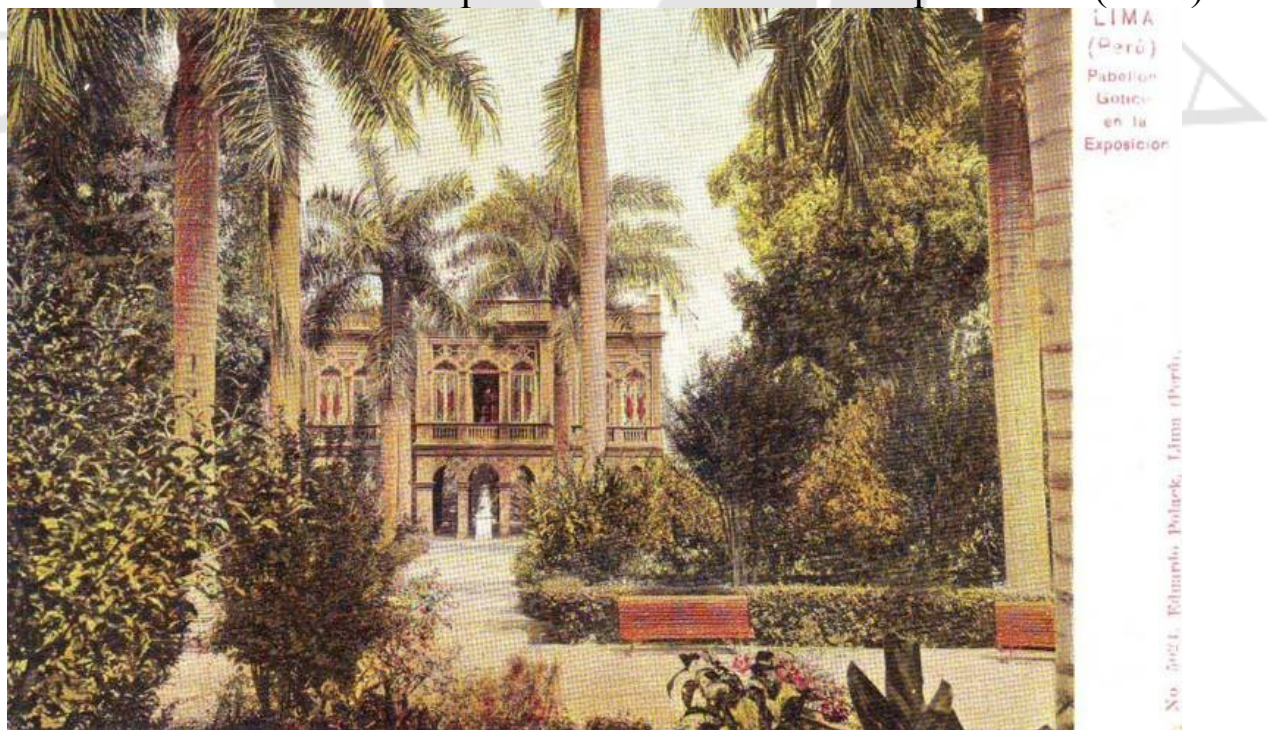

Nota: Postal en acuarela por el centenario de la independencia (1929)

Fuente: Skyscrapercity, 2010. Arborizando Lima. Recuperado de https://goo.gl/7ZgoPm

\footnotetext{
${ }^{6}$ Según la ley de Patrimonio Cultural de la Nación 28296, existe una escala de patrimonialidad, dividida en tres categorías: Edificio Histórico Monumental, Edificio de Interés Monumental y Edificio en Ambiente Monumental.
} 


\section{Figura 2.7}

Postal de la Fuente China por el centenario de la independencia (1929)

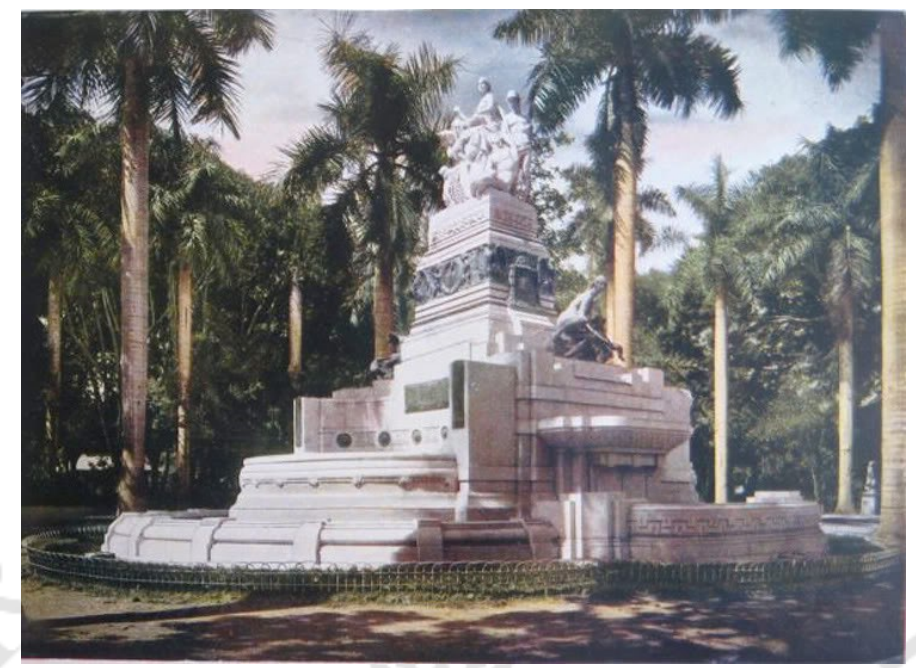

Nota: Postal en acuarela por el centenario de la independencia (1929)

Fuente: Lima la Única, 2010. La Fuente China. Recuperado de https://goo.gl/dXbohI

Por otro lado, un caso muy particular es el Museo de la Cultura Peruana, diseñado por el Arq. Ricardo Malachoswki, construido en 1924, y que tenía como principal idea la puesta en valor de la arquitectura prehispana en el Perú (Museo Nacional de la Cultura Peruana, 2013). Lamentablemente, el edificio no pasa de ser una alegoría mixta con muy poco sustento de culturas preinca e inca.

\section{Figura 2.8}

Museo de la Cultura Peruana, fachada principal, circa 1950

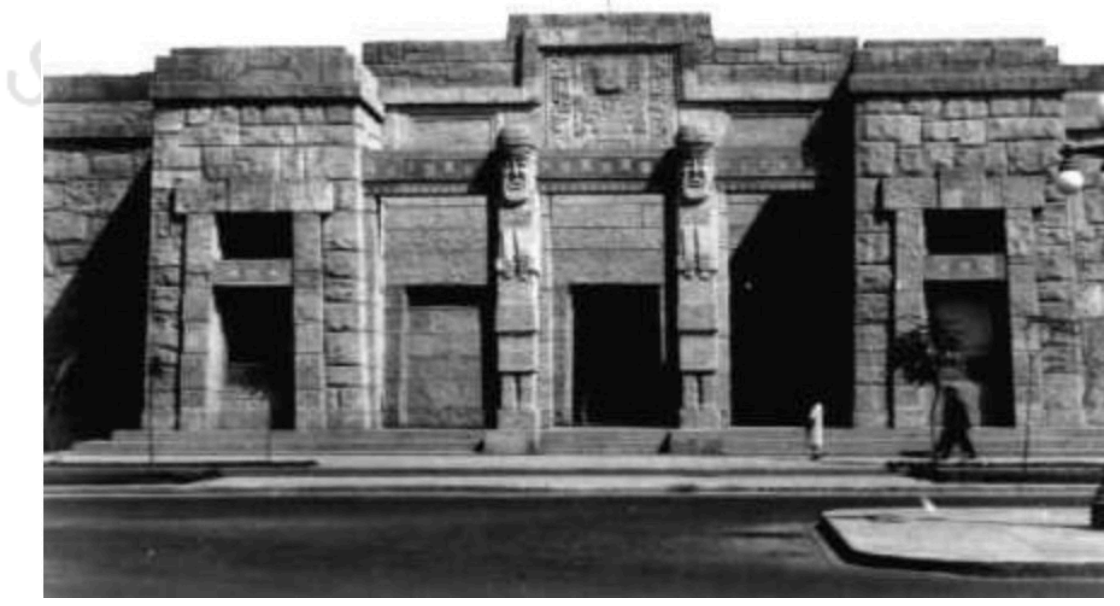

Fuente: Museo Nacional de la Cultura Peruana, 2013. Museo

Nacional de la Cultura Peruana. Recuperado de https://goo.gl/BFjCMl 
Otros ejemplos de edificios que fueron concebidos para fines distintos a los museográficos son: el Museo de la Inquisición y del Congreso, el Museo de la Nación (otrora Ministerio) y el Museo Larco (antigua casa hacienda). (Lima la Única, 2014)1.2.1 Línea de tiempo - Museos en el Perú

Figura 2.9. Línea de tiempo - Museos en el Perú

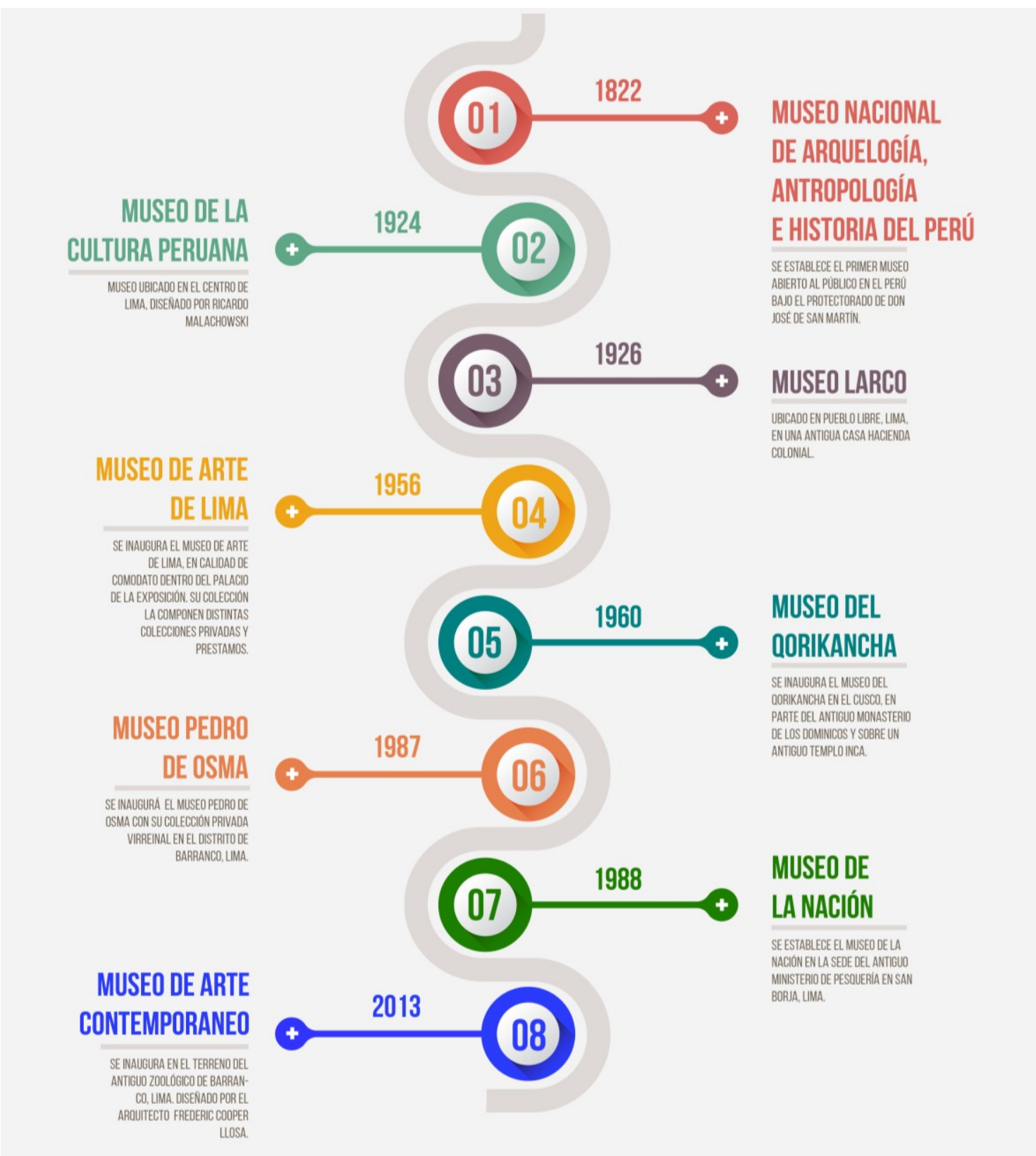

Nota: Lista basada en los museos más representativos del Perú

Fuente: Elaboración propia, 2017 


\subsection{Datos actualizados del distrito}

Estas encuestas recopiladas sobre la ciudad de Lima, así como del resto del Perú, reflejan datos importantes sobre el estado de la cultura en la actualidad. En ellas podemos observar las principales actividades recreativas, culturales o de esparcimiento realizadas por los limeños durante el 2014. Observamos que sólo un cuarto de la población asiste a museos y galerías, sin embargo, la asistencia a parques es casi del 70\% (Lima Como Vamos, 2014), lo que es un dato pertinente considerando la ubicación del MALI.

Figura 2.10

Principales actividades recreativas, culturales o de esparcimiento realizadas por limeños, 2014

Principales actividades recreativas, culturales o de esparcimiento realizadas por los limeños, 2014

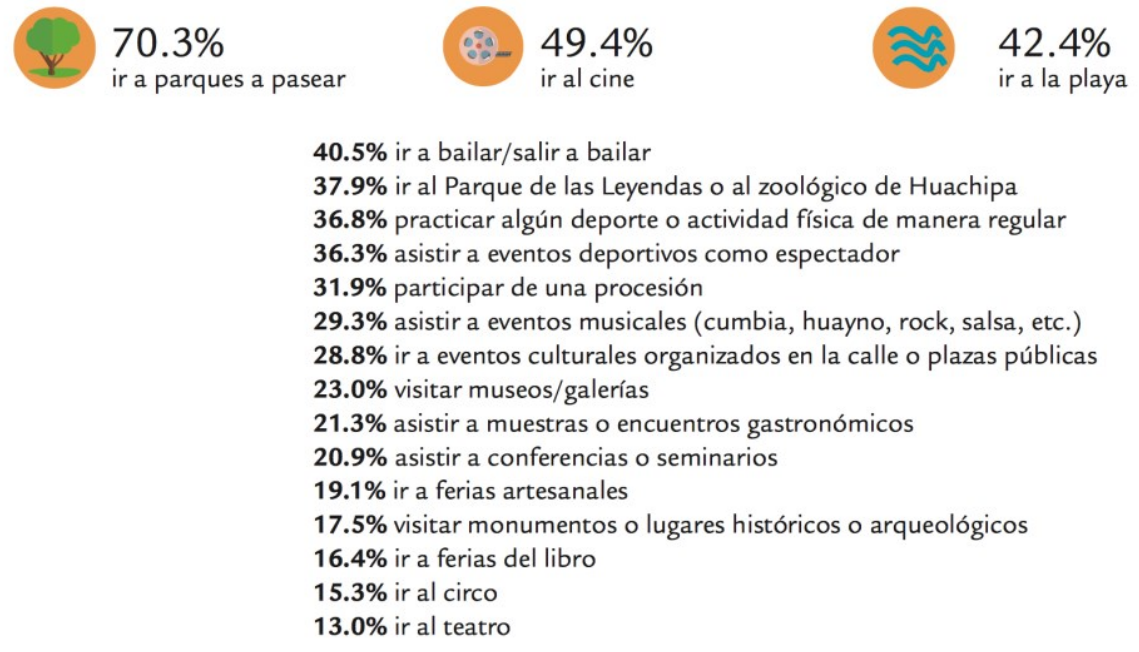

Nota: Total de entrevistados 2500 personas.

Fuente: Lima Como Vamos, 2014. Evaluando Lima. Recuperado de

http://www.limacomovamos.org/cultura/

Casi un cuarto de la población limeña identifica a los museos como la actividad cultural primaria, por otro lado, $8 \%$ de la población cree que no existe una oferta adecuada.

Igualmente, el $67.2 \%$ de la población de Lima asocia los parques como espacio público. El Parque de la Exposición encaja en esta categoría. 
Tabla 2.1

Estadísticas de visitantes nacionales y extranjeros

\begin{tabular}{|c|c|c|c|c|c|c|}
\hline \multicolumn{7}{|c|}{$\begin{array}{l}\text { 20.22 VISITANTES NACIONALES Y EXTRANJEROS A MONUMENTOS ARQUEOLÓGICOS, MUSEOS DE SITIO } \\
\text { Y MUSEOS, SEGÚN DIRECCIONES REGIONALES DE CULTURA, } 2011 \text { - } 2012\end{array}$} \\
\hline \multirow[t]{2}{*}{ Direcciones Regionales } & \multicolumn{3}{|c|}{2011} & \multicolumn{3}{|c|}{2012} \\
\hline & Total & Nacional & Extranjero & Total & Nacional & Extranjero \\
\hline Total & 2117429 & 1529031 & 579304 & 2601403 & 1759877 & 841526 \\
\hline Amazonas & 33261 & 26286 & 6975 & 32956 & 26299 & 6657 \\
\hline Áncash & 105948 & 94122 & 11826 & 117743 & 102330 & 15413 \\
\hline Apurímac & 2932 & 2603 & 329 & 3992 & 3620 & 372 \\
\hline Arequipa & 3112 & 2428 & 684 & 3047 & 2382 & 665 \\
\hline Ayacucho & 53520 & 50209 & 3311 & 51664 & 48451 & 3213 \\
\hline Cajamarca & 144681 & 135819 & 8862 & 105185 & 98063 & 7122 \\
\hline Cusco & 123691 & 74358 & 49333 & 502613 & 228179 & 274434 \\
\hline Huancavelica & 3657 & 3444 & 213 & 3898 & 3657 & 241 \\
\hline Huánuco & 52311 & 50776 & 1535 & 56694 & 55604 & 1090 \\
\hline Ica & 114406 & 53154 & 61252 & 85396 & 39044 & 46352 \\
\hline Junin & 11706 & 11604 & 102 & 13415 & 12960 & 455 \\
\hline La Libertad & 325886 & 250463 & 75423 & 338413 & 262672 & 75741 \\
\hline Lambayeque & 348828 & 303676 & 45152 & 365571 & 322051 & 43520 \\
\hline Lima & 532617 & 345469 & 187148 & 673932 & 432059 & 241873 \\
\hline Loreto & 9526 & 214 & $218^{(2)}$ & 8052 & 5307 & 2745 \\
\hline Moquegua & 3381 & 3135 & 246 & 1597 & 1491 & 106 \\
\hline Pasco & 10334 & 9700 & $634^{(3)}$ & 2642 & 2519 & 123 \\
\hline Piura & 24410 & 23532 & $878^{\prime(4)}$ & 21743 & 21208 & 535 \\
\hline Puno & 145763 & 26264 & 119499 & 146311 & 29698 & 116613 \\
\hline San Martin & 3091 & 2990 & 101 & 4186 & 4018 & 168 \\
\hline Tacna & 2607 & 2413 & 194 & 1995 & 1914 & 81 \\
\hline Tumbes & 2146 & 2143 & 3 & 2476 & 2465 & 11 \\
\hline Proyecto CARAL - SUPE (PEACS) & 59615 & 54229 & 5386 & 57882 & 53886 & 3996 \\
\hline
\end{tabular}

PEACS: Proyecto Especial Arqueológico Caral-Supe, es una unidad ejecutora del Instituto Nacional de Cultura,

encargado de la investigación, conservación y puesta en valor del patrimonio arqueológico de la ciudad de Caral, ubicada en el valle de Supe,

provincia de Barranca, departamento de Lima. Asimismo, representa a la civilización más antigua de América, desarrollada casi simultáneamente con las

de Mesopotamia, Egipto, India y China. Fue edificada por el primer estado politico que se formo en el Penú 4400 años antes que gobernaran los incas.

(1) No incluye información del Museo de Arqueologia, Antropologia e Historia Natural de Ranrahirca (riesgo en la infraestructura).

(2) No incluye información del Museo Amazónico.

(3) No incluye información del Museo Deportivo Galeria Historica de Huayllay (no funciona).

(4) No incluye información del Circuito de Museos: Museo de Arte Religioso, Centro Cultural de Piura - Museo Bolivar Periodista (cerrado temporalmente).

Fuente: Ministerio de Cultura - Oficina General de Estadística, Tecnologia de Información y Comunicaciones.

Nota: Población total de visitantes 2117429 personas

Fuente: Instituto Nacional de Estadística e Informática, 2014. Visitantes nacioanles y extranjeros a monumentos arqueológicos, museos de sitio y museos, según direcciones regionales de cultura 20112013. Recuperado de https://goo.gl/jYeqLb

\section{Visitantes por día}

Promedio de visitantes por día:

Museo (exposiciones): 250 personas

Talleres: 200

Total: 450

Proyección en 5 años: 500 personas en los talleres +500 personas en museo $=1000$ personas. (Gerencia del MALI, 2016) 


\section{Desigualdad cultural}

La encuesta revela que los habitantes que pertenecen a los sectores socioeconómicos $\mathrm{A} / \mathrm{B}$ realizan más actividades recreativas y culturales que aquellas que pertenecen al D/E. En particular, la diferencia es mayor en los siguientes casos: ir al cine (64.9\% vs 40.8\%), ir a ferias del libro (32.0\% vs $8.9 \%)$, asistir a muestras o encuentros gastronómicos (35.0\% vs 12.3\%), asistir a conferencias o seminarios (35.1\% vs $13.9 \%)$ e ir al teatro (26.3\% vs $6.6 \%)$. Como se observa, las diferencias según/ estrato socioeconómico son abismales y manifiestan una gran desigualdad. Además, un mayor porcentaje de personas del nivel socioeconómico C asiste al Parque de Las Leyendas, al Parque zoológico de Huachipa (39.3\%) o va al circo (17.4\%), en contraposición a los otros estratos. (Lima Como Vamos, 2014. Evaluando Lima)

Por otro lado, se puede ver que la cultura y la oferta cultural se concentra en los sectores $\mathrm{A} / \mathrm{B}$, estableciendo una brecha con los sectores menos favorecidos.

\subsection{Conclusiones parciales}

El Museo de Arte de Lima se encuentra en un jardín de importancia cultural e histórica para el centro de la ciudad; que es además la entrada al casco antiguo y el único pulmón verde de la zona. Por ello, el proyecto de ampliación del MALI debe considerar las necesidades sociales de la comunidad local y también el impacto a nivel metropolitano que tendrá, a través de los estudios pertinentes del área, cuyo principal elemento integrador será el nivel 0 , como techo de la ampliación y jardín del museo.

Asimismo, en las estadísticas nacionales, vemos que el número de visitantes anuales está creciendo, y que la mayoría se concentran en Lima, por lo que esta ciudad debe contar con el equipamiento y la infraestructura necesaria para recibir a esta cantidad de personas.

Estas encuestas evidencian la necesidad de volver la cultura más accesible, y que esta se debe llevar a cabo en un espacio público, para generar dinamismo e interacciones entre distintos grupos sociales. Además, el hecho que involucre a un museo, servirá para crear y generar un sentido de identidad en la comunidad. 


\section{CAPÍTULO III: MARCO TEÓRICO}

\subsection{Teorías de intervención}

La intervención en edificios históricos de valor patrimonial es un asunto muy complejo, en el cual se deben encontrar dos posturas que usualmente se consideran opuestas: la conservación, entendida como mantener en el tiempo el monumento en cuestión, y la restauración, que en realidad involucra la renovación, traer de vuelta a la existencia y/o a uso el predio. (Hernandez, 2007)

\subsubsection{Siglo XIX}

Según Viollet-Le-Duc ${ }^{7}$ :

Restaurar un edifico no es preservarlo, ni repararlo, ni reconstruirlo; es reinstaurar una condición de entereza que nunca podría haber existido en algún tiempo en particular (...) En Asia, en tiempos antiguos y modernos cuando un templo o palacio se dilapidaba por el tiempo, otro fue, o es, erigido al lado. Su descomposición no es considerada como una razón para destruirlo; es dejado a la acción del tiempo, que actúa sobre el cómo su dueño por derecho, y que gradualmente lo consume. Los romanos reemplazaban, pero no restauraban; prueba de ello es, que no existe palabra en el latín que corresponda a "restauración" en el sentido moderno. Instaure, renovare, no significan restaura, sino reinstaurar- hacer de nuevo. (Viollet-le-Duc y Wethered, 1875, pp. 9-10).

Se observa que la tendencia en Francia, y en el resto de Europa continental era la de intervenir los edificios e inclusive reconstruir parte de ellos con nuevas adiciones que mantenían el mismo estilo original, pero con ciertas modificaciones estilísticas que reinterpretaban el diseño original a la realidad y función deseadas.

En otras palabras, el arquitecto o restaurador tenía la potestad de modificar y crear sobre un edificio antiguo, ya que se consideraba más importante su valor artístico que su valor histórico. Este tipo de restauración se conocía como "style"8 por su nombre en francés o "revival" en el Reino Unido.

\footnotetext{
${ }^{7}$ Emmanuel Viollet-Le-Duc: arquitecto e historiador francés del siglo XIX famoso por su interpretación de la resturación de edificios de la era medieval.

${ }^{8}$ Style: estilo de arquitectura que imita la estética de periodos anteriores (Grecia clásica, Renacimiento, entre otros), que se hizo popular luego de la "World’s Columbian Exposition" de Chicago en 1893. 
Como se verá en las siguientes imágenes, gran parte de la restauración era a criterio del arquitecto, ya que, en la mayoría de los casos, no existían documentos ni imágenes previas que podrían indicar como era originalmente el edificio; se intuía cómo pudo ser y cómo se vería mejor.

Figura 3.1

Postal del antes y despúes de la intervención de Viollet-Le-Duc en Carcassone
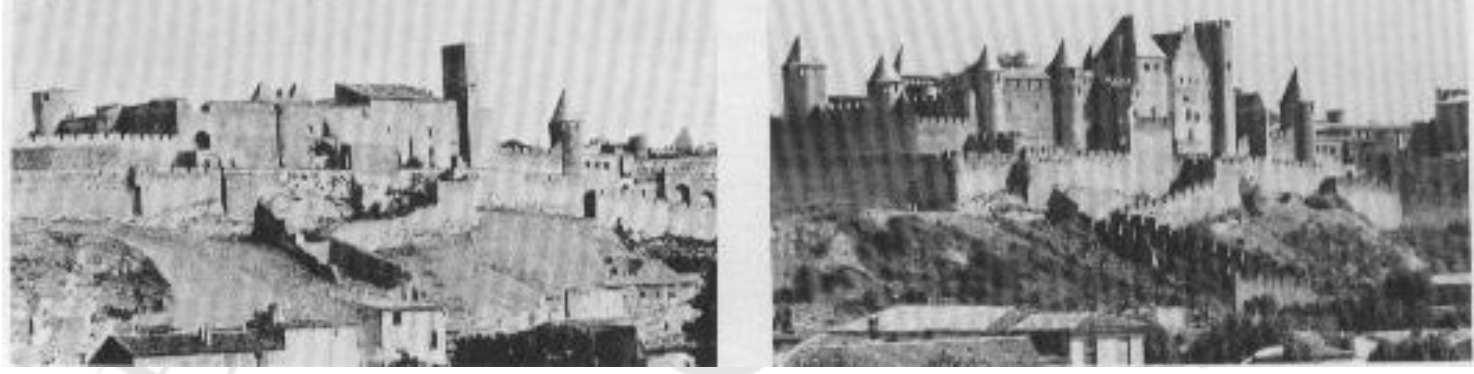

Nota: Imágenes de libro.

Fuente: Viollet-le-Duc y Wethered, 1875.

Por otro lado, John Ruskin se avocó hacía la preservación de los edificios tal y como eran encontrados, con mínimas intervenciones que simplemente debían retrasar al máximo el deterioro natural del monumento y evitar que se desplomase.

Figura 3.2

Antes y después de intervención de Viollet-Le-Duc en Pierrefonds
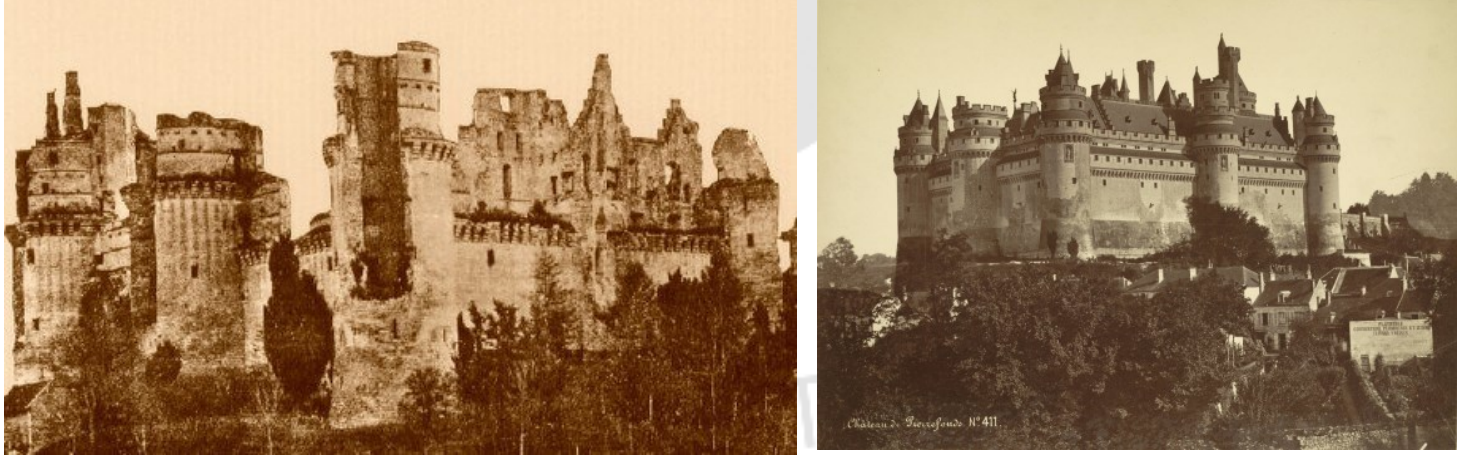

Nota: Imágenes de archivo en linea.

Fuente: Taylor Noakes, 2012. Ode to Pierrefonds. Recuperado de https://goo.gl/kI6GmU

\footnotetext{
${ }^{9}$ John Ruskin: pensador social y filántropo inglés (8 de febrero de 1819 - 20 de enero de 1900) reconocido por sus teorías de preservación de edificios históricos y critico de la época Victoriana. 
Sobre la restauración, Ruskin sostenía:

Acéptenla como tal, traigan el edificio abajo, tiren sus piedras en las esquinas olvidadas, hagan lastre de ellas, o mortero, si quieren; pero háganlo honestamente, y no lo usen para levantar una Mentira en su lugar. Y miren a esa necesidad en la cara antes de que venga, y de repente pueden prevenirla (...) Cuiden bien de sus monumentos, y no tendrán que restaurarlos (...) Observen un edificio antiguo con cuidadosa ansiedad; cuídenlo tan bien como puedan, y a cualquier costo, de cualquier influencia de dilapidación (...) sujétenlo con hierro donde se suelte; párenlo con maderos donde se hunda; no se preocupen por lo antiestético de la ayuda: mejor una muleta que un miembro mutilado. (Ruskin, 2006, pp. 244-245)

El siguiente ejemplo muestra la Abadía de Tintern (siglo XIII), que ha sido conservada y preservada de la manera más pura posible y la que Ruskin defendió durante el siglo XIX.

Figura 3.3

Abadia de Tintern, interior

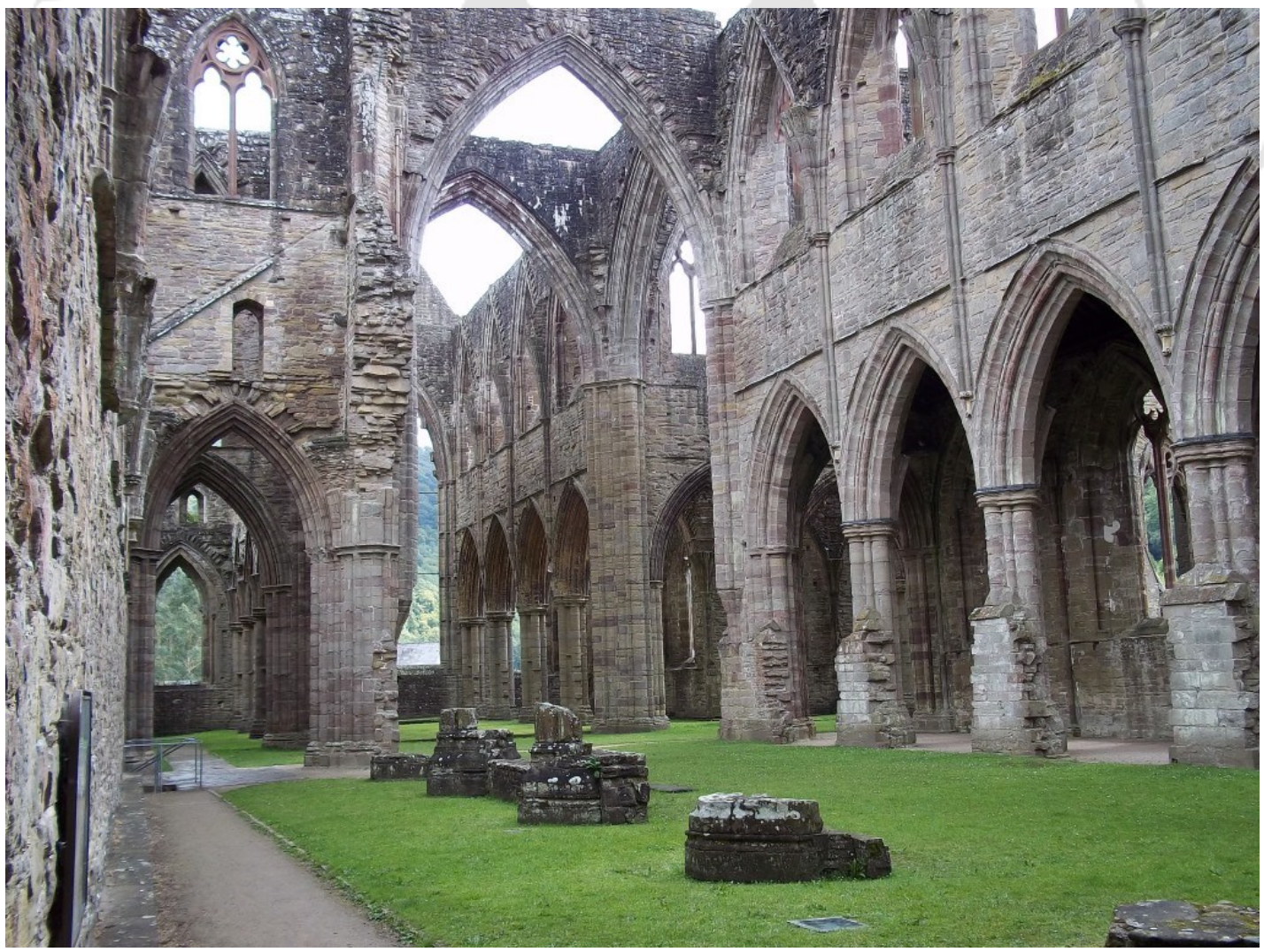

Nota: Vista interior desde la primera planta de la iglesia en ruinas.

Fuente: The Aposition, 2013. Tintern Abbey. Recuperado de https://goo.gl/RWucgy 
En el caso de Italia, Camillo Boito ${ }^{10}$, se avocó a la restauración filológica; el libro se cita:

Priorizó la conservación sobre la restauración. La segunda debería tomar lugar solo cuando el monumento estuviera en peligro de desaparecer y fuera absolutamente necesaria, y la intervención debe mantenerse al mínimo, para así evitar cualquier tipo de reconstrucción estilística. Adicionalmente, Boito creía en la preservación de la autenticidad del monumento respecto a su época y modificaciones. Él argumentaba que era necesario que las partes que fuesen colocadas en el periodo de restauración debían ser visiblemente diferentes al material original. (Graham y Howard, 2008, p. 249)

Este proceso debía ser documentado cuidadosamente para saber que piezas eran adicionadas y que piezas eran las originales. Los edificios en sí también servían como documentos históricos para la posteridad:

Considerando que los monumentos de arquitectura del pasado no son solamente valiosos para el estudio de la arquitectura sino que también contribuyen como documentos esenciales para explicar e ilustrar las facetas de la historia de la humanidad a través del tiempo, deben, en consecuencia, ser escrupulosamente y religiosamente respetados como documentos en los cuales cualquier alteración, por muy pequeña que fuese, y si parece ser parte del original, puede guiar y eventualmente generar juicios erróneos. (Jokilehto, 2009, p. 52)

Durante la influencia de este periodo en Italia, se restauraron edificios a la manera de "forma simplificada". Las adiciones indicaban como era o debía ser el edificio originalmente. Se limpiaba el edificio de posibles interferencias y se respetaba el estado en el que se encontraban, optando por dejar las intervenciones que se hacen visibles para diferenciar el edificio original de las modificaciones posteriores.

10 Camillo Boito: arquitecto e ingeniero italiano (30 de octubre de 1836 - 28 de junio de 1914). Reconocido por ser gran crítico e historiador de la arquitectura. Tuvo gran influencia en la restauración de la época. 
Figura 3.4

Comparación de la Porta Ticinese
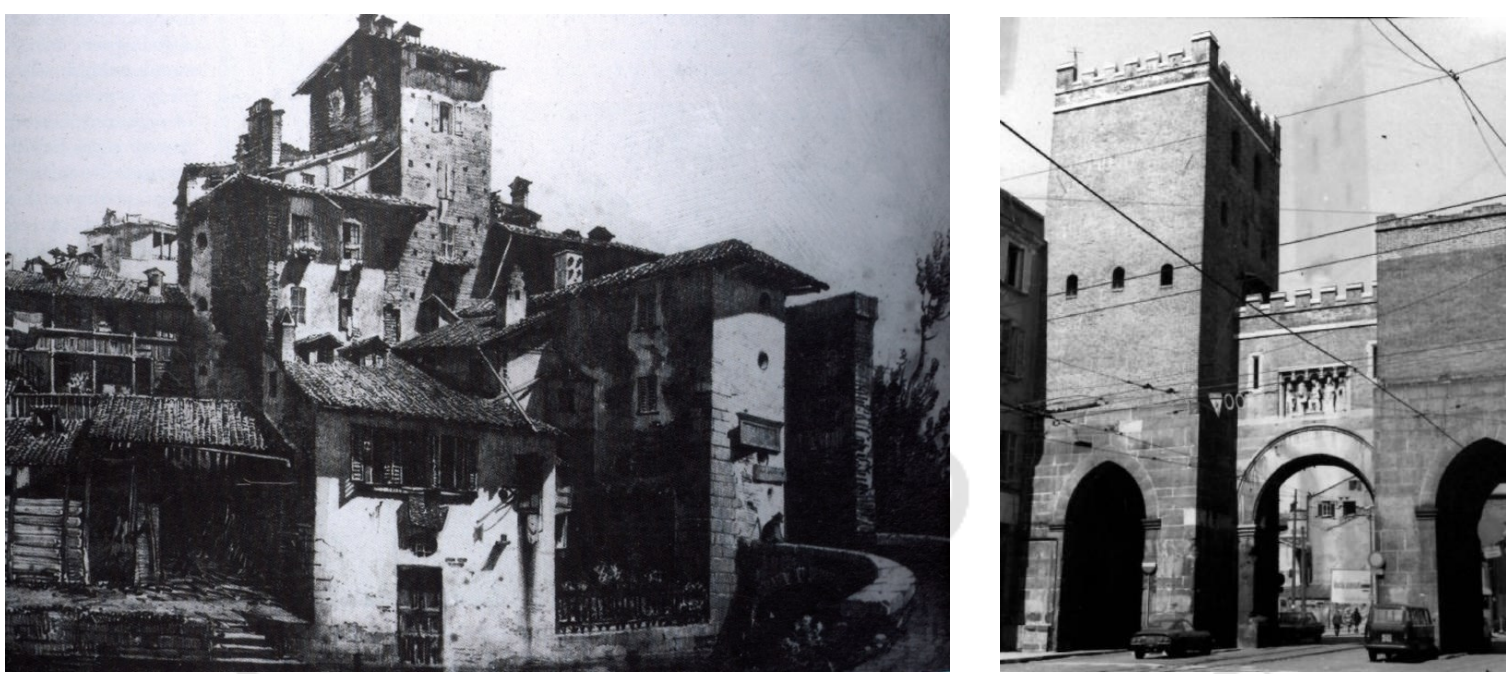

Nota: Imagen muestra el estado anterior y el posterior a la restauración de Boito Fuente: Lombardia Beni Culturali, 2013. Schede. Recuperado de https://goo.gl/Vrv596

\subsubsection{Siglo XX}

Durante el primer tercio del siglo XX se empezó a formar la visión sintetizada de conservación y restauración que se conoce hoy en día. Gustavo Giovannoni ${ }^{11}$, uno de los autores de la Carta de Atenas $^{12}$, afirmaba que:

.... el arquitecto restaurador debe cumplir el triple rol historiador, constructor y artista”, y además debe considerar las múltiples condiciones ambientales (...) (Su) teoría era realmente compleja, ya que adicionaba la necesidad de rehabilitar a la necesidad de conservar. En consecuencia, hacia el proyecto de conservación también de "recomposición" para que pudiera acomodar nuevas tecnologías y nuevos métodos de habitar en ambientes históricos específicos. (Hernandez, 2007, p. 65)

Este elemento de recomposición, permitió que arquitectos como Carlo Scarpa pudiesen transgredir ciertas limitaciones de épocas anteriores y crearan nuevos espacios totalmente innovadores, como la intervención en el Castillo Vecchio, símbolo de esta era de restauración.

\footnotetext{
${ }^{11}$ Gustavo Giovannoni: arquitecto italiano (1873-1947) reconocido por ser uno de los padres de la visión moderna de la arquitectura. ${ }^{12}$ Carta de Atenas: manifiesto ideado en el IV Congreso Internacional de Arquitectura Moderna en 1933. Este document es famoso porque dio inicio a la era moderna de habitar y diseñar ciudades. 
Figura 3.5

Intervención de escaleras laterales

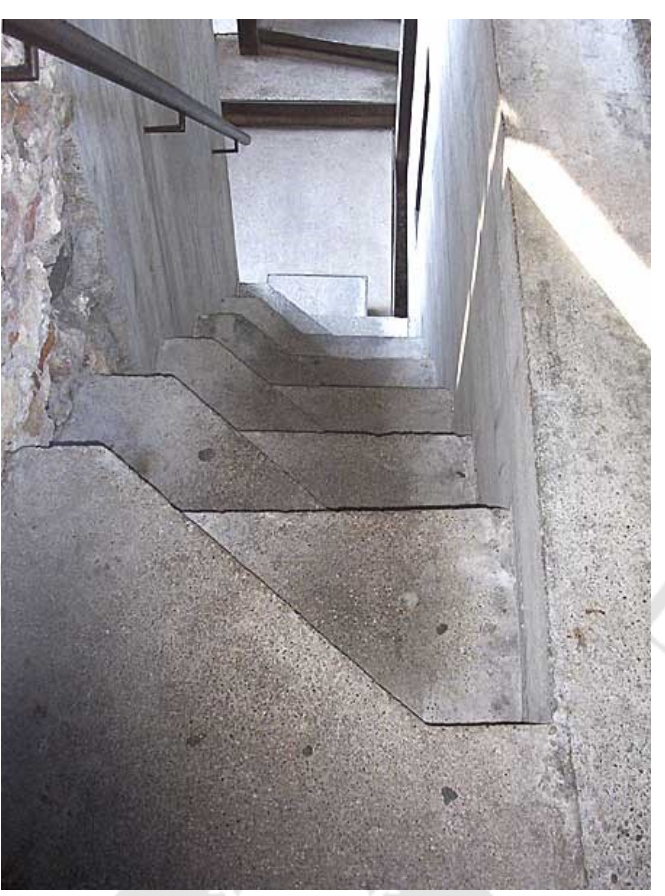

Nota: Vista hacia escaleras de concreto nuevas

Fuente: Museo di Castel Vecchio, 2014. Fotos.

Recuperado de https://goo.gl/2XLP6b

Figura 3.6

Sala de ingreso con puentes elevados

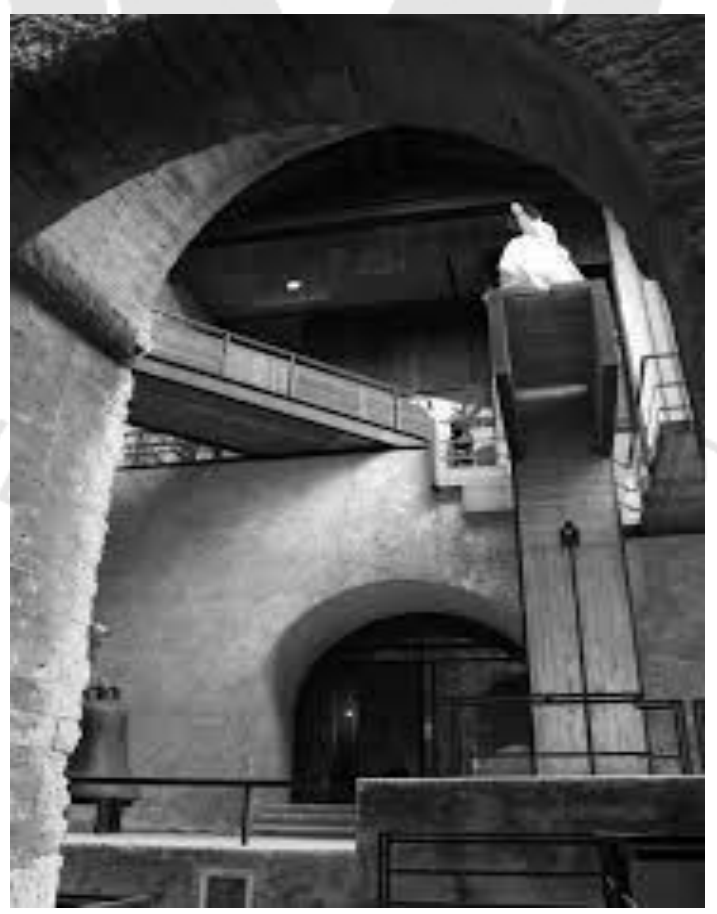

Nota: Vista exterior hacia segundo piso.

Fuente: Museo di Castel Vecchio, 2014. Fotos.

Recuperado de https://goo.gl/2XLP6b 
Figura 3.7

Diseño para intervención de los jardines

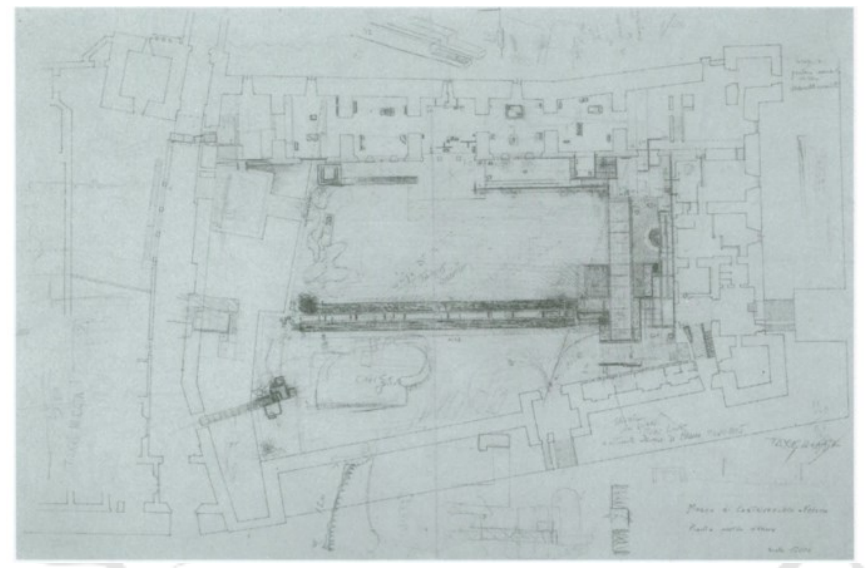

Nota: Grabado de la época

Fuente: Museo di Castel Vecchio, 2014. Fotos. Recuperado de https://goo.gl/2XLP6b

\section{Figura 3.8}

Interior de sala de exhibición
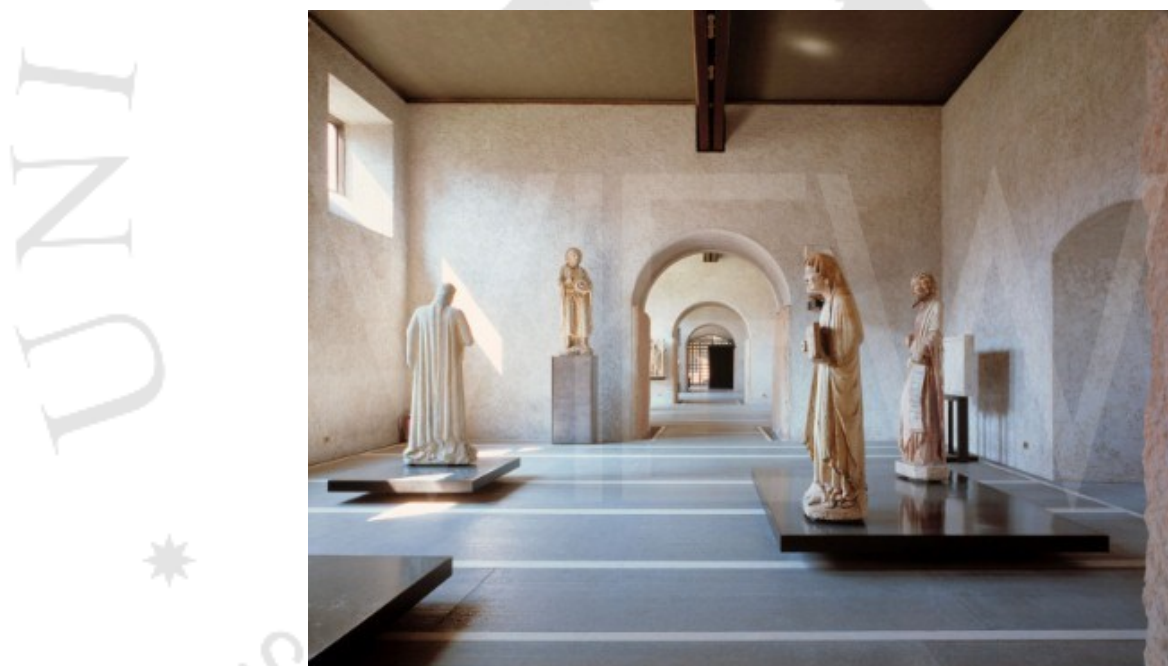

Nota: Esculturas de mármol en sala de exhibición interior

Fuente: Museo di Castel Vecchio, 2014. Fotos. Recuperado de https://goo.gl/2XLP6b

Sin embargo, no fue hasta 1964, con la creación de la Carta de Venecia ${ }^{13}$ que la concepción de Giovannoni de integración entre la historia y la contemporaneidad en la arquitectura fue comprendida:

\footnotetext{
${ }^{13}$ Carta de Venecia: creada el 31 de mayo de 1964. Uno de sus alcances más importantes es la concepción de "monumento historico" como partes de la ciudad y no solo un edificio. 
$\mathrm{Su}$ tesis ambiental no fue entendida por aquellos que creían que lo antiguo y lo nuevo eran incompatibles, basados en una concepción ortodoxa de valores históricos. Hoy, países como España, Italia, o Grecia, las leyes específicas de protección han congelado la arquitectura de muchos centros urbanos históricos en fachadismo, lo que ha causado que pierdan vitalidad y funcionalidad. Esto es lo Cesare Brandi ${ }^{14}$ define como el crimen de "falsificación", un proceso en el que las normas culturales fuerzan intervenciones para "cubrir" elementos estilísticos tomados de la historia de la arquitectura. (Hernandez, 2007, p. 66)

Brandi defendía la restauración "crítica" para así generar intervenciones funcionales que dinamizaran las urbes, como un conjunto de edificios integrados, y no simples fachadas sueltas en una trama urbana sin sentido.

\subsection{Criterios actuales}

Más adelante, hacia el nuevo milenio, con la creación de la Carta de Cracovia ${ }^{15}$ en el 2000, las ciudades son concebidas como elementos “orgánicos". En el artículo 8 de la Carta se cita:

.. el mantenimiento de ciertas características espaciales y cromáticas son requeridas, pero no la similitud estilística de formas del pasado. Con el objetivo de defender las intervenciones contemporáneas como parte integral de la restauración de monumentos, el artículo 4 señala: La reconstrucción de partes enteras en el estilo del edificio" debe ser evitada (...) Si es necesaria para el debido uso del edificio, la culminación de partes más extensas funcionales y espaciales deben reflejar arquitectura contemporánea. (Hernandez, 2007, p. 67)

La siguiente imagen muestra un ejemplo del Alvaro Siza, en el que se ve un espacio monumental intervenido por un volumen nuevo ortogonal, frente a un monasterio antiguo de estilo medieval. El contexto inmediato es modificado, lo que genera un nuevo espacio urbano, pero sin perder la calidad original.

\footnotetext{
${ }^{14}$ Cesare Brandi: crítico e historiador del arte (8 de abril de 1906 - 19 de enero de 1988). Fue el primer director del Instituto Central de Restauración de Italia en Roma.

${ }^{15}$ Carta de Cracovia: documento ideado en el 2000 que prioriza la conservación de la autenticidad e integridad de los casos urbanos antiguos, a través del su uso y la apropiada intervención arquitectónica. 
Figura 3.9

Centro Galego de Arte Contemporaneo (1988), confrontado al Monasterio de Santo Domingo de Bonaval (siglo XIII-XVIII, Santiago de Compsotela, España

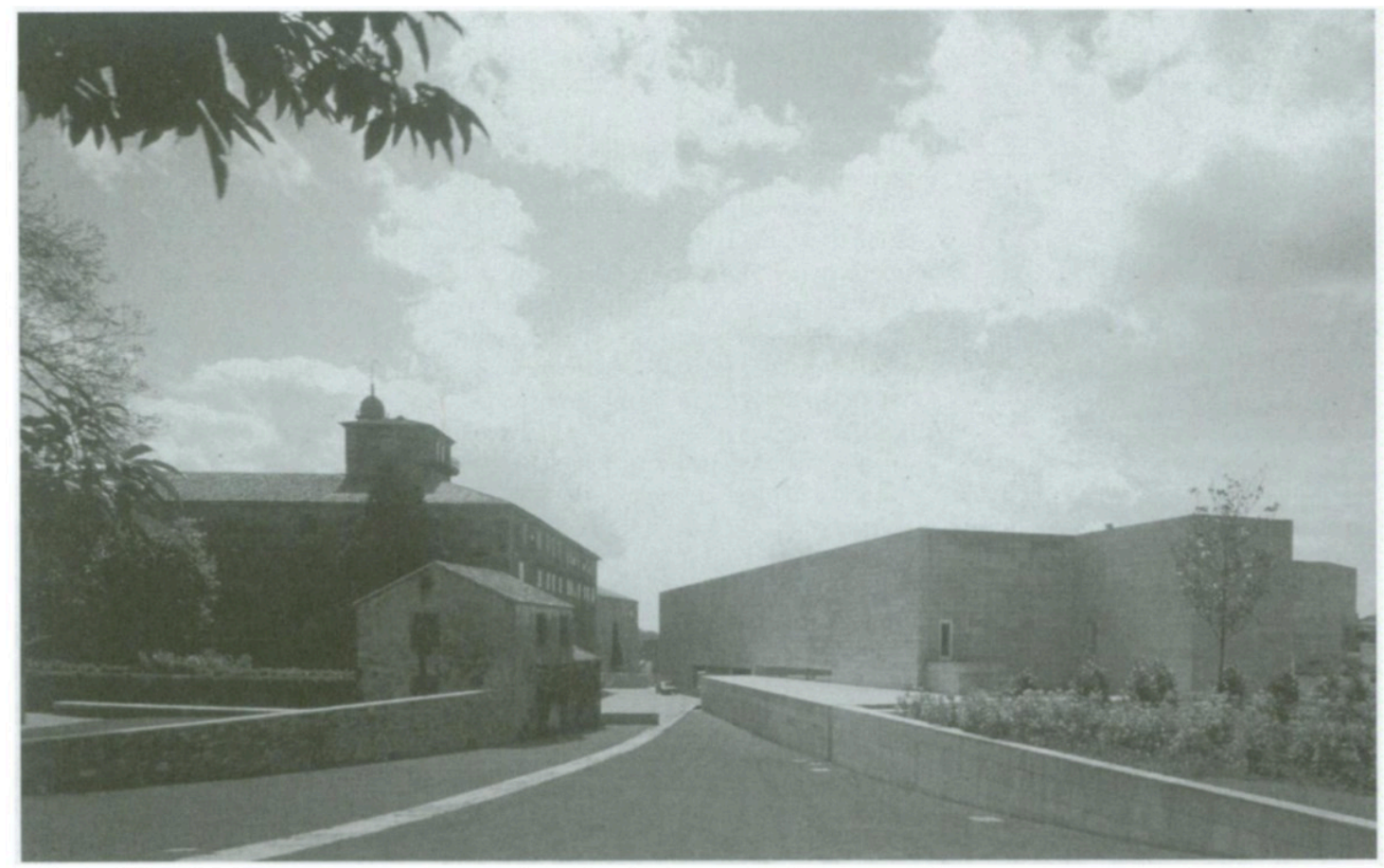

Nota: Fotografía de libro

Fuente: Hernandez, 2007, p. 68

\subsection{La influencia de Alois Reigl}

Si se toma como referencia la escala de valores de Alois Reigl ${ }^{16}$ en su libro "The Modern Cult of Monuments", se identifican cuatro puntos que deben ser tomados en cuenta para decidir que se debe hacer con un edificio de carácter monumental; claro está, que el predio debe haber sido primero declarado como tal por su valor histórico o cultural.

1. Valor de tiempo: aprecia el pasado por sí solo. No permite intervención alguna y lleva en consecuencia al olvido de edificio.

2. Valor histórico: da valor a la capacidad que tiene el edificio de representar el pasado y de servir como documento histórico. Este "documento" debe ser preservado en el tiempo lo mejor posible para la posteridad.

3. Valor intencional conmemorativo: da valor a la intención inicial de los constructores originales del edificio en cuestión. Este punto en particular incentiva más aun la conservación en el tiempo del edificio para mantenerlo "siempre presente y vivo".

\footnotetext{
${ }^{16}$ Alois Riegl: historiador austrohúngaro (Linz, 14 de junio de 1858 - Viena, 17 de junio de1905). Se le conoce por su gran colaboración en la recopilación histórica de distintos estilos arquitectónicos. 
4. Valor de contemporaneidad: este se puede dividir en dos, el valor artístico, que suele ser subjetivo al artista y al observador, y el valor de uso, que sostiene que todo edificio histórico debe tener cierto uso para poder ser mantenido en condiciones óptimas. (Riegl, 1903, pp. 21-51)

Estos puntos, en conjunto con una correcta interpretación de las teorías previamente presentadas, pueden llevar a un diseño adecuado para intervención.

\subsection{Tipologías y lineamientos generales}

\subsubsection{Tipos de museos (Architectural Review, 2012. Tipologías de museos):}

Museo Palacio: edificios de planta cuadrada o rectangular, con patio(s) central(es). Cerrados al exterior. Inspirados en la época clásica, evidente en la simetría y proporción monumental.

Figura 3.10

Arq. Karl Friederich Schinkel. Altes Museum (1930), Berlín (Alemania)

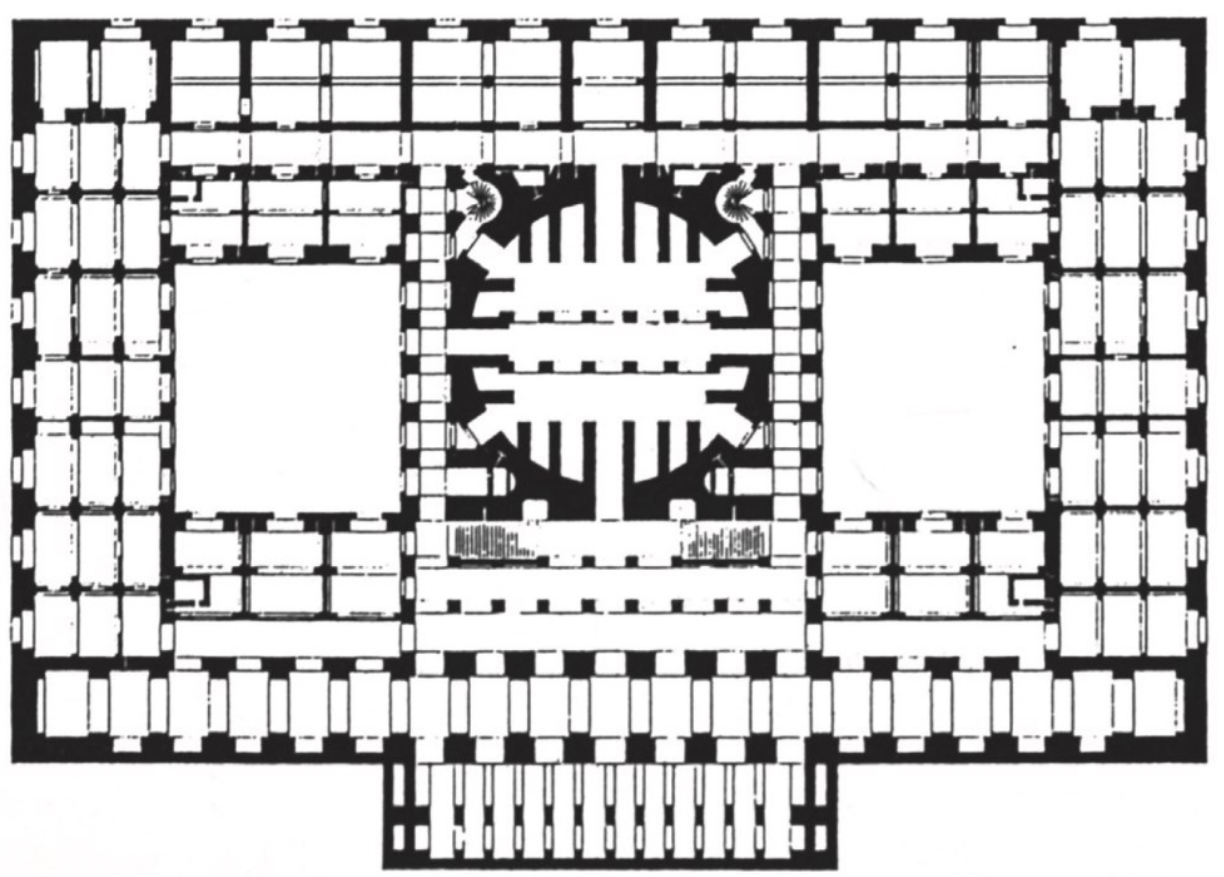

Nota: Planta esquemática.

Fuente: Architectural Review, 2012. Tipologías de museos. Recuperado de https://goo.gl/tiDzYk 
Figura 3.11

Arq. Mies Van Der Rohe. Pabellón de Barcelona (1929), Barcelona (España)

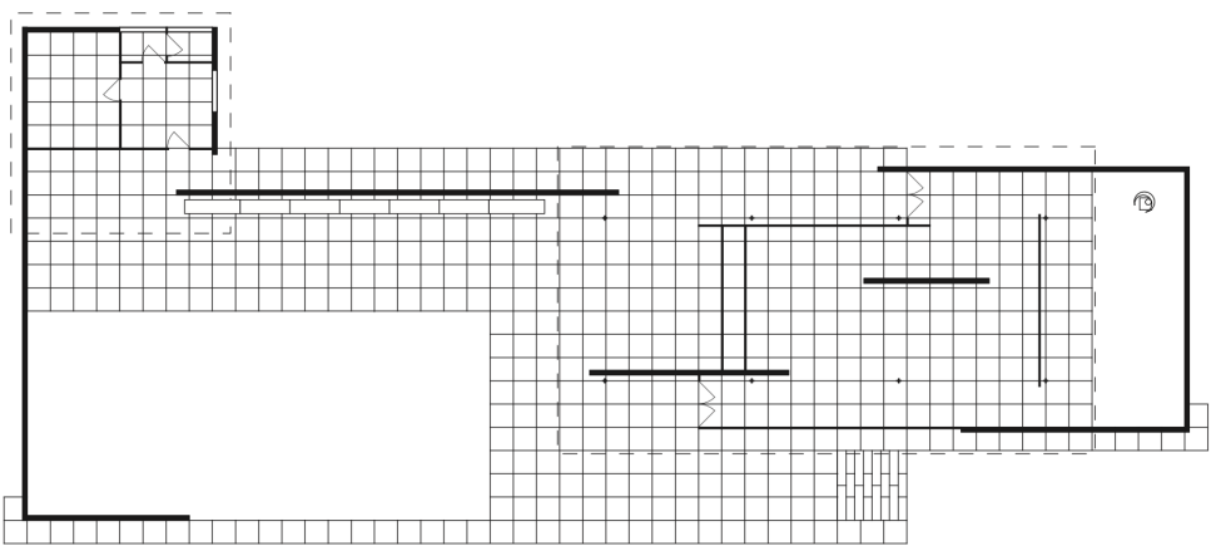

Nota: Planta esquemática.

Fuente: Architectural Review, 2012. Tipologías de museos. Recuperado de https://goo.gl/tiDzYk

Museo Modernista (museo para la ciudad): Propio del movimiento modernista, es una plataforma en la que los espacios fluyen y las relaciones se establecen a través de paredes permeables. La planta usualmente es ortogonal y los ambientes tienen vistas al exterior.

Museo Vertical: es un edificio cuyo espacio principal es el centro del mismo, y que conecta al resto de niveles física y visualmente. Este tipo de museo rompe las formas convencionales del modernismo y cobra protagonismo por sí solo, no por lo que alberga.

Figura 3.12

Arq. Frank Lloyd Wright, Guggenheim Museum (1959),

Nueva York (EEUU)

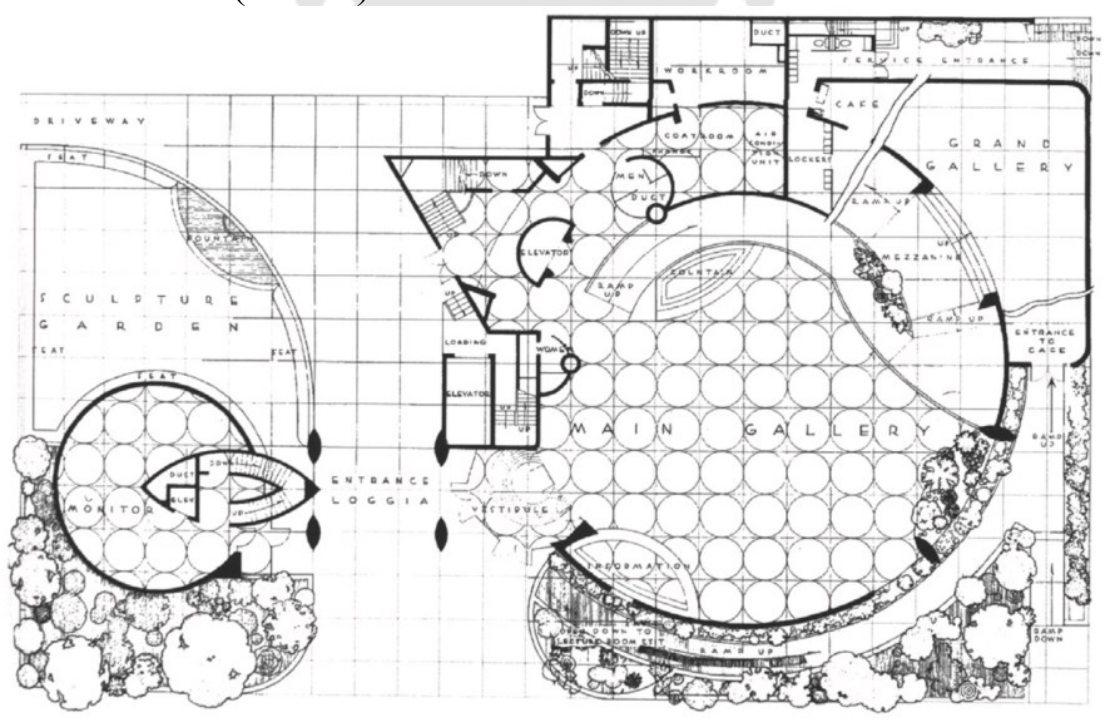

Nota: Planta esquemática.

Fuente: Architectural Review, 2012. Tipologías de museos. Recuperado de https://goo.gl/tiDzYk 
Museo Maquina: edificio con estructura metálica movible que proporciona flexibilidad y dinamismo. Se vuelve un contenedor exento de lo que alberga; un espectáculo en sí. Se mantiene la diferencia marcada entre espacio abierto-cerrado, pero empiezan a aparecer espacios urbanos públicos (plazas, parques) contiguos a estos edificios.

Figura 3.13

Arq. Renzo Piano \& Arq. Richard Rogers. Centre Pompidou (1977), Paris (Francia)

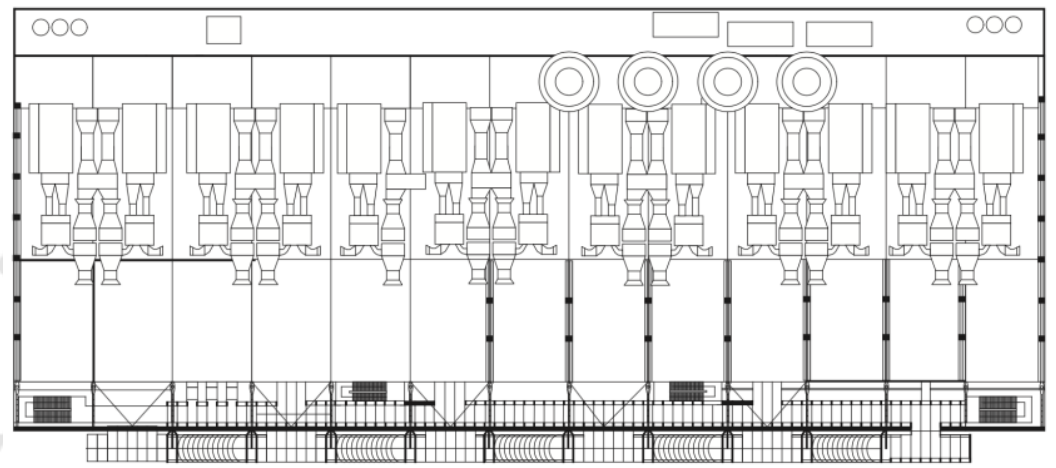

Nota: Planta esquemática

Fuente: Architectural Review, 2012. Tipologías de museos. Recuperado de https://goo.gl/tiDzYk

Museo-Ciudad: el museo transiciona y se vuelve en sí una pequeña ciudadela. Es un edificio que se articula a través de patios centrales y en donde el esquema de circulación lleva al visitante de ambientes abiertos a cerrados y viceversa. Es un museo como sistema urbano; un reflejo de lo que sucede en el exterior.

Figura 3.14

Arq. James Stirling, Neue Staatsgalerie (1984), Stuttgart (Alemania)

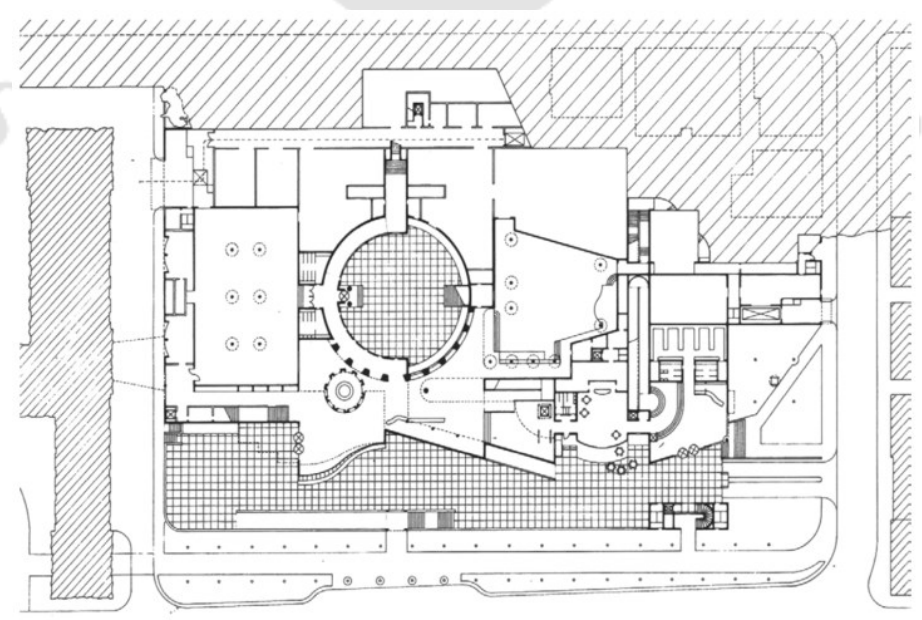

Nota: Planta esquemática

Fuente: Architectural Review, 2012. Tipologías de museos. Recuperado de https://goo.gl/tiDzYk 
Museo Implante: este tipo de edificios actúan como regeneradores urbanos de áreas industriales o espacios residuales. Se "implantan" en zonas de la ciudad que carecen de dignidad e identidad. Usualmente se reutilizan zonas industriales, que son intervenidas y reacondicionadas en su totalidad, para albergar los nuevos usos propuestos.

Figura 3.15

Arq. Steven Holl. Kiasma Museum (1998), Helsinki (Finlandia)

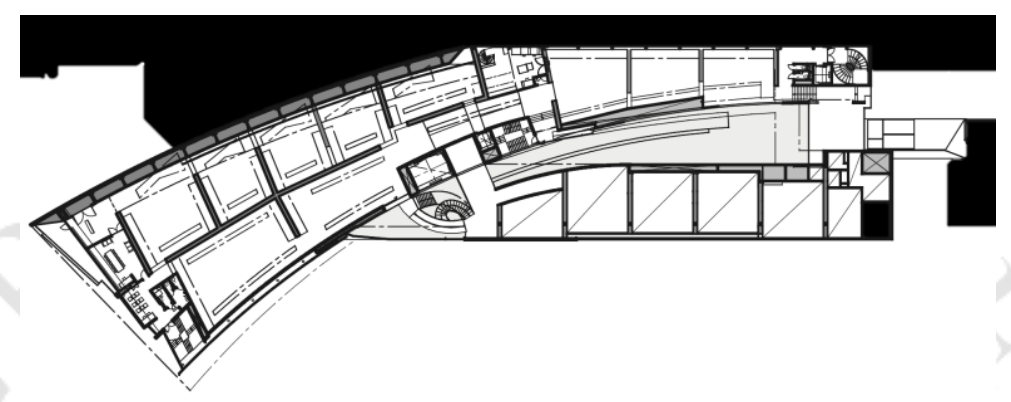

Nota: Planta esquemática

Fuente: Architectural Review, 2012. Tipologías de museos. Recuperado de https://goo.gl/tiDzYk

Museo Prostético: son edificios que, como los "implante", son producto de la intervención de un edificio o zona urbana prexistente. Sin embargo, en este caso se guarda la jerarquía de los ambientes del edificio predecesor. La intrusión arquitectónica en estos lugares es como un parasito que los devuelve a la vida. Usualmente los edificios intervenidos son espacios seculares o instituciones gubernamentales.

Figura 3.16

Arq. Meyer, Scherer \& Rockcastle. Mill

City Museum (2004), Minneapolis

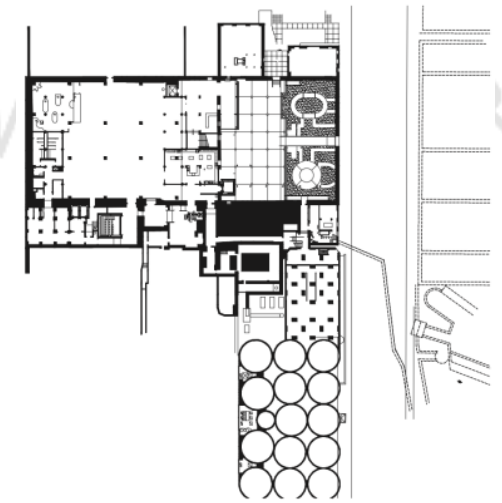

Nota: Planta esquemática.

Fuente: Architectural Review, 2012. Tipologías de museos. Recuperado de https://goo.gl/tiDzYk 
Museo Paisaje: este tipo de museos vuelve al contexto natural pieza central de la intervención. Busca un equilbrio entre las formas abstractas de la arquitectura y la naturaleza rocosa, orgánica, perseverante en el tiempo. Este tipo de arquitectura pone en evidencia la importancia de lo natural, y que esto debe ser protegido.

Figura 3.17

Arq. Paulo David, Centro de Artes (2004), Madeira (Portugal)

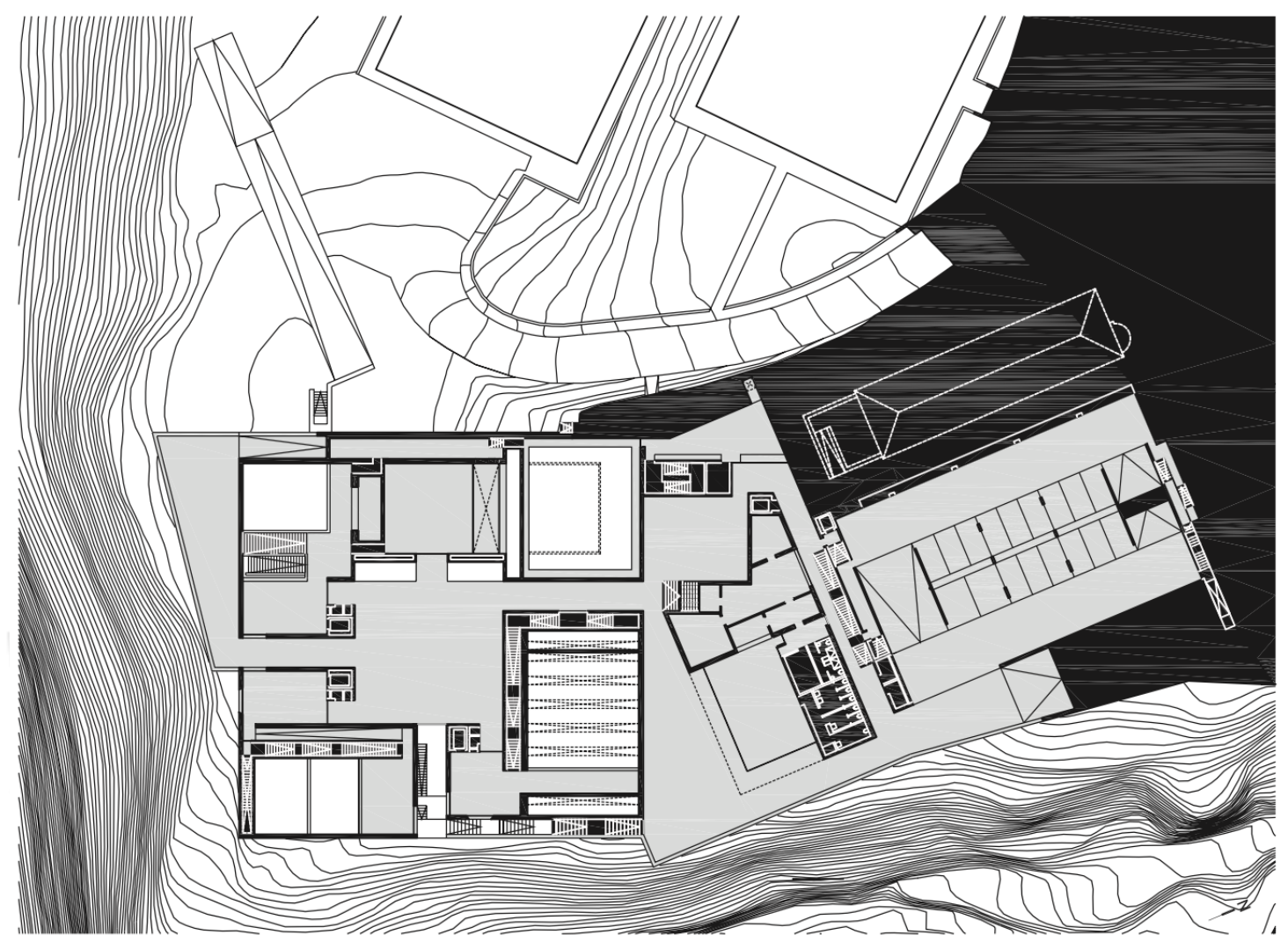

Nota: Planta esquemática.

Fuente: Architectural Review, 2012. Tipologías de museos. Recuperado de https://goo.gl/tiDzYk

\subsubsection{Lineamientos de Ernest Neufert ${ }^{17}$ para habilitación de museos y salas de exhibición:}

Este libro permite hacer un repaso sobre los aspectos de diseño que se deben tener en cuenta cuando se proyecta un museo. Estas son consideraciones generales mínimas que deben existir para que un edificio de exposición pueda funcionar en condiciones óptimas:

\footnotetext{
${ }^{17}$ Ernst Neufert, asistente de Walter Gropius. Publicó El Arte de Proyectar; este documento es considerado una guía para el diseño arquitectónico en general.
} 
a. Las salas de los museos deben servir para proteger de la humedad, de la sequedad, del sol, del polvo, de agresiones o robos a las piezas de arte.

b. Además, deben estar bien iluminadas (en el sentido más amplio) lo cual se consigue mediante:

Para su conservación:

i. El archivo de dichas piezas (grabados, dibujos originales, etc) en carpetas guardadas en armarios (con cajones) de $80 \mathrm{~cm}$ de profundidad por $160 \mathrm{~cm}$ de altura.

Para exhibición:

ii. En soportes adecuados en exhibiciones abiertas al público (óleos, frescos, exposiciones itinerantes, etc).

c. Es preferible tener unas varias alas disponibles en un edificio en lugar de un gran corredor interminable.

d. Debe haber espacio para el embalaje, administración, envío, sala de conferencias, talleres y servicios.

e. Por otro lado, también se debe pensar en los museos como Centros Culturales, por lo que debe haber un espacio el trabajo y/o estudio, como bibliotecas o mediatecas, para la relajación, como cafeterías o restaurantes, y almacenaje, que puede incluir el área de depósitos y restauración en general.

El público ha de poder contemplar las obras expuestas sin esfuerzo. Esto exige fijar unos itinerarios de recorrido y ordenar las obras a exponer.

A ser posible se han de situar cada grupo de cuadros en una única sala y cada cuadro en una pared. Esto exige salas pequeñas. La proporción entre superficie de pared y superficie en planta es mayor en las salas grandes necesarias para colgar grandes cuadros, ya que el tamaño de las salas depende del tamaño de los cuadros. El ángulo visual del hombre son $5-4^{\circ}$ hacia arriba desde el ojo del espectador, lo cual implica que dada una distancia de contemplación de 10m, los cuadros se han de colgar desde $4.90 \mathrm{~m}$ por encima del punto de vista hasta $70 \mathrm{~cm}$ por debajo. Sólo los grandes cuadros superarán estos límites por arriba y por abajo. Los cuadros de tamaño pequeño deberían colgarse de manera que su centro de atención (línea de horizonte del cuadro) quedase a la altura de los ojos. (Neufert, 1995, p. 528) 
Superficie necesaria por cuadro

Superficie necesaria por obra pictórica
$3-5 \mathrm{~m}^{2}$ de pared

$6-10 \mathrm{~m}^{2}$ en planta

Diagrama 3.1. Diagrama de ángulos de visión de obras de arte

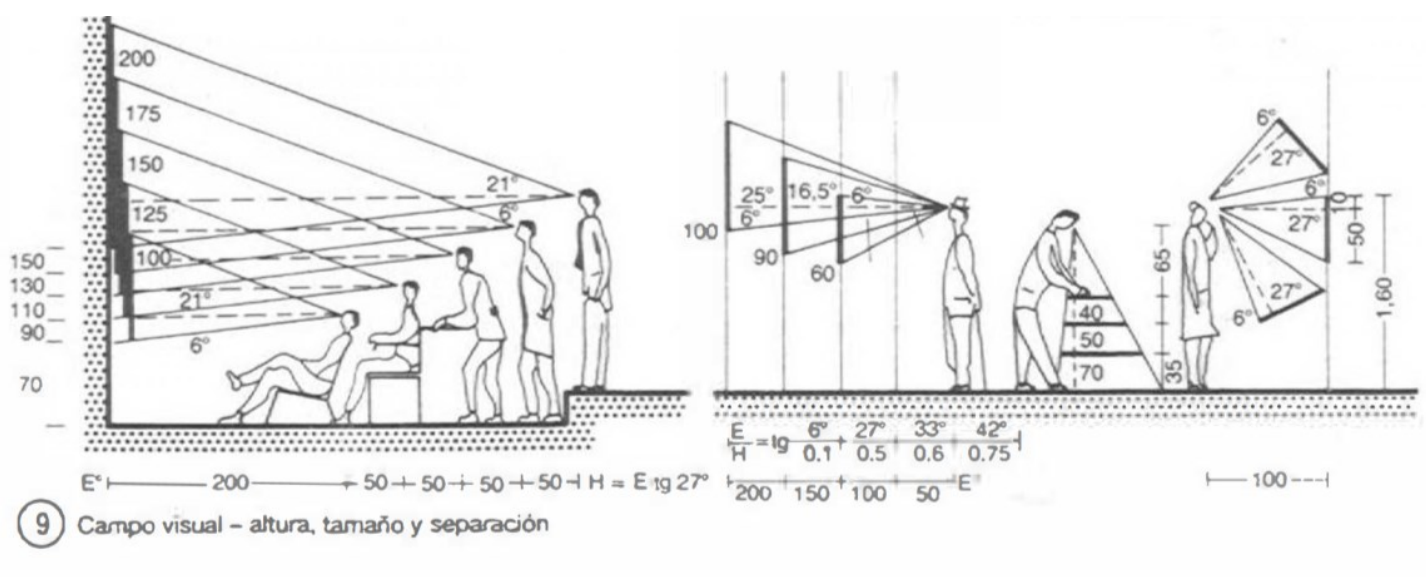

Fuente: Neufert, 1995, pp. 528

El cálculo de la iluminación adecuada en un museo es un proceso teórico; lo decisivo es lo calidad de la luz. Últimamente se tiende a la iluminación artificial, en vez de intentar aprovechar lo luz natural siempre cambiante, aunque entre a través de lucernarios orientados al norte.

En una sala con iluminación natural lateral, la superficie óptima para colgar cuadros se sitúa entre los $30^{\circ}$ y los $60^{\circ}$ de reflexión de la luz, para una altura del techo de $6.70 \mathrm{~m}$ y el antepecho de ventana de $2.13 \mathrm{~m}$ en el caso de pinturas, o de $3.0-4$ a $3.65 \mathrm{~m}$ en el de esculturas.

Figura 3.18

Diagrama de iluminación artificial

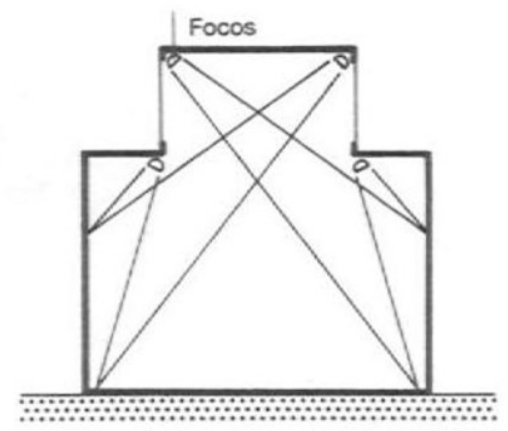

(2) Instalar las fuentes de luz artificial de manera que se asemeje a la luz natural

Fuente: Neufert, 1995, pp. 528 
Figura 3.19

Esquema de circulaciones

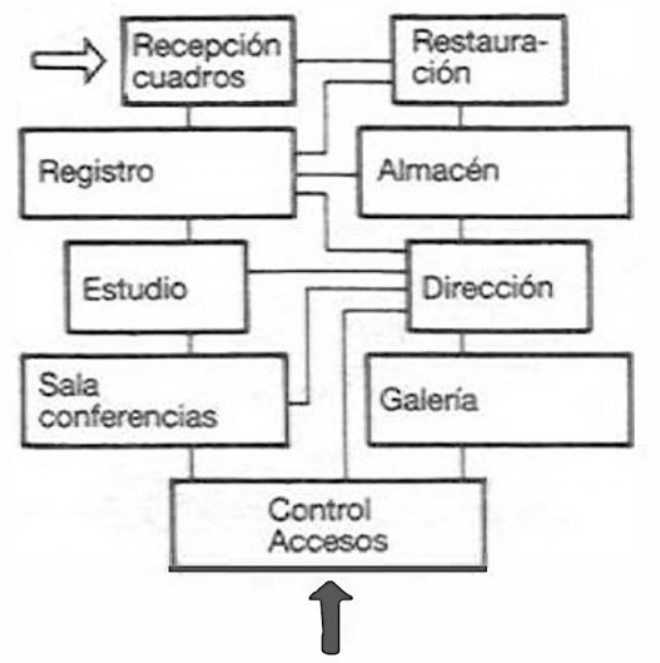

(1) Esquema de circulaciones

Fuente: Neufert, 1995, pp. 529

Ordenación del conjunto: es preferible disponer varias alas alrededor de la entrada que un pasillo interminable que dé la vuelta a todo el edificio. Se ha de prever suficiente espacio para desempeñar los trabajos de embalaje, envío, administración, salas para proyector diapositivas, talleres de restauración y salas de conferencias. Los castillos, palacios y monasterios deshabitados son idóneos poro su transformación en museos, suelen ofrecer un morco más adecuado para exponer los objetos históricos que los llamados fríos edificios modernos.

Figura 3.20

Sección de museo Cívico de Turín

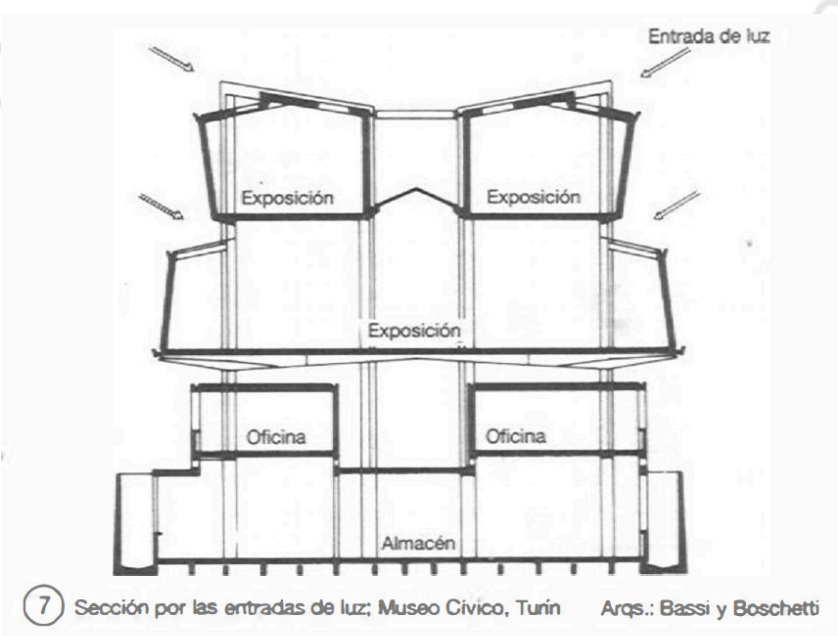

Fuente: Neufert, 1995, pp. 529 
Los museos no deberían proyectarse exclusivamente como lugar para realizar exposiciones, sino también como centro cultural. Esta multifuncionalidad debe reflejarse en el programa de espacios, salas de exposiciones permanentes e itinerantes. Para trabajo o estudio: bibliotecas, mediatecas, salas de conferencias. Para relajación: zonas de descanso, cafetería, restaurante. Finalmente, también para: almacenaje, conservación, depósitos, talleres, organización y administración. (Neufert, 1995).

\subsubsection{Definiciones, clasificación y consideraciones generales para proyectar un museo según la Enciclopedia Plazola ${ }^{18}$}

A continuación, se citan textualmente las definiciones, clasificaciones y consideraciones generales de planificación, ubicación y organización de un museo (Plazola Cisneros, 1977, pp. 324-343):

- Definiciones:

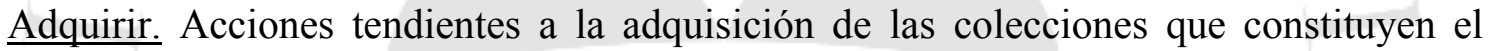
contenido del museo.

Arqueta. Caja pequeña destinada a diversos usos.

Colección. Constituye el principal atractivo del museo y se encuentra contenida dentro de un espacio diseñado especialmente para colocar las piezas, en el que se marca la circulación apropiada de la exhibición.

Comunicar. Esta función engloba todo aquello que atiende a posibilitar el conocimiento del patrimonio cultural del museo fuera de éste, para que así el público pueda saber en dónde y cómo puede obtener información relacionada con la educación y la cultura.

Conservar. Función de características especializadas que tiene que ver con el permanente buen estado de las piezas y su mantenimiento.

Conservatorio. Establecimiento costeado por el Estado con el objeto de fomentar y enseñar ciertas artes.

\footnotetext{
${ }^{18}$ Enciclopedia Plazola: Compendio de distintos volúmenes sobre el diseño de distintas tipologías en la arquitectura.
} 
Curaduría. Donde se realiza el estudio, documentación y control de las colecciones del museo.

Ecomuseo. Es la creación de museos de arquitectura doméstica en centros históricos en áreas rurales y marginadas.

Espacio. Los espacios se definirán con respecto a dimensiones, acabados e iluminación conforme a los términos técnicos que los rigen. El espacio debe causar emoción y sorpresa en el visitante cuando se introduce en la atmósfera cultural del museo. En él se realiza la planeación de los eventos culturales y exposiciones.

Exhibir. Frente al público y en relación con éste, es la más importante de las funciones del museo, ya que aquél va a conocer a través de los resultados de una buena museografía las piezas y colecciones que dan razón de ser al museo.

Exposición permanente. Representa el tesoro del museo.

Exposición temporal. Es la que permanece durante un lapso de dos o más meses en un museo.

Exposición de novedades. Es el anexo donde se exhiben las nuevas adquisiciones del museo.

Gabinete. Mueble utilizado para guardar objetos pequeños y muy apreciados.

Gliptoteca. Gabinete donde se guarda una colección de piedras grabadas.

Investigar. Tarea propia de los especialistas sobre los distintos orígenes e historia de las coleccio-nes.

Objetos. Son los principales protagonistas del museo; representan la producción artística del hombre a lo largo de la historia. Son de tamaños, formas y estilos variables (cuadros, esculturas, textiles, vasijas, herramientas, armas, etc.).

Oploteca. Del griego hoplothéke, de hóplon, arma y théke depósito. Colección o museo de armas antiguas, preciosas o raras.

Oráculo. Respuesta de una divinidad a la que se le hacían consultas según unos ritos determinados.

Personal. Conjunto de personas que laboran dentro del museo con funciones específicas para el buen funcionamiento y mantenimiento del edificio. 
Pinacoteca. Galería o museo de pinturas Programa interior. Diseñado para el visitante con todos los informes sobre el contenido del museo, su colección, exhibiciones, servicios y principales atractivos.

Público. Constituido por todos los visitantes al museo, el cual sigue un recorrido atractivo y funcio-nal por las áreas de mayor interés durante su estancia.

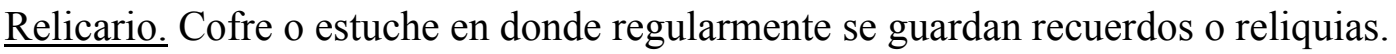

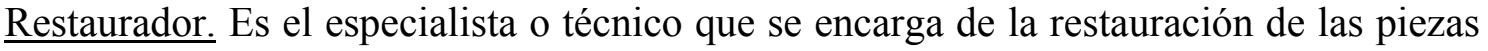
de arte.

\section{- Clasificación:}

Según temática (Plazola Cisneros, 1977, p. 325):

Arte contemporáneo. Son aquellos que presen-tan colecciones recientes y actualizadas de artistas contemporáneos o de moda.

Ciencia y técnica. En ellos se exponen los avances más notables dentro de la ciencia y la tecnología, así como los inventos y progresos dentro de los campos de la física, matemática y cibernética.

De masa. Son aquellos que se visitan por su colección o atractivo comercial temporal.

Dinámicos. Son espacios atractivos e innovadores en donde la distribución de sus áreas está ligada a los recursos museográficos más modernos.

Escolares y comunitarios. Sirven para la conservación y divulgación de los testimonios naturales y culturales de su ámbito.

Especializados. En ellos se exhiben objetos es-pecíficos de un tema en especial (armas, medicina, ecología, embarcaciones, etcétera).

Experimentales. Se basan en el uso de métodos didácticos novedosos que convierten al público en participante de todo un espectáculo de dinamismo. Los museos por ser centros de enseñanza objetiva y permanente deben tener la capacidad de presentar gran variedad de temas a partir de lo cual se tiene una clasificación especializada y un nombre específico según lo que se exhibe.

Históricos. Las colecciones presentadas y exhibidas hablan de la historia de la nación, lugares o individuos. Se dividen en dos categorías: aquellos que concentran eventos, lugares y personas y dedicados a un periodo o modo de vida en particular de una región. 
Por ubicación:

De sitio. Están ubicados en las zonas arqueológicas o en determinados monumentos históricos importantes; funcionan como introductores a los recorridos por dichas zonas (Museo del Templo Mayor en México, el de las Pirámides de Egipto, etc.).

Locales. Están integrados por diversas colecciones o testimonios culturales del lugar (Museo Histórico Fuerte de san Diego, Muralla China, etc.).

Nacionales. Pretenden dar una visión general de la formación histórica del país, desde sus orígenes hasta el presente.

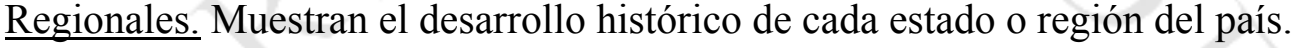

En la actualidad el museo tiene que ser fundamen-talmente un centro de comunicación entre el objeto y el espectador que propicie al hombre a vivir emocional $\mathrm{y}$ psicológicamente la confrontación con el objeto y su significado.

\section{- Planificación:}

El autor propone distintos elementos que intervienen en la planificación de un museo, entre los cuales destacan la museografía, y el diseño de circulaciones y exposición. Ambos dependen de distintos profesionales, pero en especial, de un arquitecto a cargo del proyecto.

Personas que intervienen en el diseño de un museo:

El museo por ser un lugar público o privado de enseñanza, requiere un diálogo entre una cultura y el hombre; su creación está precedida por la investigación y por la definición del objeto finalidad del mismo, de la que se desprende la labor museológica de conservación, protección y uso del recinto. Los museos se crean mediante dos líneas paralelas: la línea del equipo de asesores científicos y conservadores dedicados a la colección, y la línea de los arquitectos y museógrafos que deben darle forma, secuencia y contemporaneidad a los espacios, ritmos, dimensiones, etcétera, para que la finalidad pedagógico-estética tenga proyección humana íntegra.

Los museos son el resultado de una ardua labor de especialistas: arquitectos, museógrafos, investigadores, restauradores, asesores educativos e incluso personal de seguridad. 
Debe haber interdependencia entre asesores, científicos, arquitectos, investigadores, estudiantes y artistas, lo cual es determinante para darle fisonomía propia al partido y a los espacios, y conseguir una ubicación cronotópica correcta de la obra, que es el principal problema arquitectónico, porque engloba a todos los demás.

La esencia del proyecto debe ser experiencia viva que exige que al transitar o habitar sus espacios se produzca una comprensión del presente gracias a la visión retrospectiva, y no sólo una observación del pasado.

La arquitectura debe ser auténtica y verdadera y contener la formación espacial del programa planteado por todos los que intervienen en la obra que se construye.

Todos ellos deben realizar diferentes acciones que permitan cumplir con éxito las funciones fundamentales de todo museo: la conservación y preservación del patrimonio y su promoción y difusión de éste entre la sociedad.

Para elaborar el programa arquitectónico, la relación entre los arquitectos y el resto de los profesionistas debe ser muy estrecha, a fin de tomar en cuenta todas las necesidades de tal manera que se logre un equilibrio entre su ubicación, funcionamiento y circulación.

El programa tendrá como fin ser dinámico y social, generador de múltiples actividades, eventos y servicios al visitante en su difusión cultural.

\section{Ubicación y terreno:}

Para la edificación de un museo hay restricciones en cuanto a la ubicación. Los reglamentos establecen como condición contar con estacionamiento y que los accesos sean amplios y no obstruyan la circulación vial.

Si el museo será educativo, se ubicará en lugares estratégicos entre la extensa red de escuelas públicas y particulares de fácil acceso.

En el caso de museos de sitio se debe llevar a cabo un levantamiento topográfico, estudios orográfico, hidrológico, climático, de vegetación, vientos dominantes, materiales y acerca de la historia del lugar; en los museos urbanos se realiza un análisis detallado del área circundante al terreno, traza urbana, fondo legal, casco urbano, equipamiento (hoteles, estacionamiento, comercios), infraestructura, vialidad, dirección de circulación, ancho de las vías principales, etc.

En el caso de una adaptación la ubicación del predio se realiza considerando el edificio que reúna las mejores condiciones en adaptación a museo por su espacio y su localización. Se debe realizar un levantamiento del sitio considerando un radio de acción de por lo 
menos $300 \mathrm{~m}$ para analizar tipos de construcciones, si hay edificios catalogados como históricos o considerados patrimonio de la humanidad que se encuentren alrededor del edificio o dentro de ese radio para determinar la factibilidad construc-tiva: planos de equipamiento, infraestructura (agua, luz, drenaje, teléfono, otros), transporte, alturas de construcciones, estilo y construcción dominante.

En un museo de planta nueva. La elección del sitio se hace en coordinación con los especialistas que intervienen en el proyecto arquitectónico, asesores de contenido y constructores.

Primero se define el objeto y función del museo que está determinado principalmente por la colección que se expondrá. Por lo general, con base en este dato se determina el estilo arquitectónico de la construcción.

\section{Proyecto urbanístico:}

El escritor postula que un museo debe ser parte del resultado de una buena planificación urbana, la cual debe a su vez ser producto de un estudio de contexto metropolitano.

Al iniciar el proyecto se debe realizar un estudio para lograr una buena planificación. Por la magnitud del proyecto, es necesario contextualizar el inmueble en el entorno urbano y regional considerando los siguientes elementos:

Las referencias inmediatas del inmueble, como calles, plazas, edificios públicos, vecinos y colindancias. Se procede a delimitar el terreno para crear un plan de aprovechamiento que comprende uso de suelo con sus accesos principales y su acceso exterior, uso de lotes colindantes y límites de terreno.

Se analizan las condiciones de propiedad inmobiliaria, como adquisición de terreno, costo de la adquisición y tiempo de trámites. Se debe considerar la posibilidad de construcción por etapas, además de obtener información sobre la infraestructura, como agua, luz y drenaje.

Se recomienda emplear en el diseño general, el diseño de acabados y la museografía, elementos formales y materiales de la región con el objeto de que le den personalidad propia al inmueble.

El entorno natural es un auxiliar inmediato de cualquier propuesta arquitectónica, ya que muestra colores, formas y texturas que pueden ser retomadas para definir su carácter presente y futuro. 


\section{Plan económico:}

La economía es parte fundamental para la operación de los museos públicos o privados. Estos se apoyan en los recursos generados por sus propios visitantes y también en las aportaciones del Estado o por Asociaciones de Amigos de los Museos o convenios con algunas empresas o sociedades.

En la actualidad, los grandes centros culturales son generadores de una economía en potencia por contar dentro de su diseño con espacios destinados al comercio y promoción de los objetos que en él se exhiben, cafeterías, restaurantes y bares.

\section{Adaptaciones y ampliaciones:}

El proyecto de crecimiento en un museo se puede establecer con base en las colecciones que contenga y las mejoras que requiera para el servicio al público, en varias formas:

Ampliación. Construcción de uno o varios anexos según planes de renovación.

Adaptación. Obra que se hace en un museo o una construcción ya existente, adecuando los espacios a las necesidades y procurando respetar los valores arquitectónicos del inmueble.

Crecimiento aumentando techo. Esta es una de las formas de ampliación más sencilla, ya que sólo se anexa una estructura al techo.

Crecimiento entre pisos. Cuando se trata de construcciones antiguas se aprovecha su altura para ganar entrepisos.

Crecimiento por sustitución sin aumentar volumen. Si el edificio es antiguo, por tener otra distribución, debe sufrir cambios y adaptaciones en sus partes interiores sin que se afecte su estructura.

Construcciones subterráneas. Son las que se encuentran abajo del edificio o forman un sótano.

Aumentos parciales al edificio. Esto se logra por medio de pórticos, terrazas, techado de patios, etc.

Crecimiento aumentando volumen. Las propuestas son variables, desde demoliciones parciales del edificio y construcción de áreas nuevas o ane-xando terrenos vecinos o restaurando espacios.

Construcción nueva. Es la más común para el nuevo concepto de los grandes centros culturales de la actualidad. 


\section{Organización:}

El museo es parte de una de las propuestas culturales más buscadas y promovidas por las instituciones gubernamentales, la iniciativa privada y la sociedad civil.

Esto se debe al gran número de visitantes que llegan a estos espacios, lo que permite una amplia difusión de ideas y conocimientos de sus colecciones. Por esta razón, el museo debe generar toda una gama de actividades y servicios para atender a un público diverso. Para hacer frente a todos estos aspectos, el museo requiere una organización interna eficaz, capaz de realizar labores de planeación, administración y ejecución de programas de trabajo. Los espacios destinados para estos servicios requieren un porcen-taje considerable de la superficie del inmueble (40\% o más).

$\mathrm{Su}$ edificación debe generar una imagen propia, identificable como museo y capaz de integrarse al entorno, lo cual significa tomar en cuenta las relaciones entre las escalas urbana, arquitectónica, social, cultural y ecológica para establecer un adecuado planteamiento arquitectónico.

\section{Información:}

La información al público sirve para dar la bienvenida al visitante del museo, quién se apoyará en este servicio para que su visita sea una experiencia completa; esta puede ser proporcionada con:

Medios orales. Realizados por tos guías especializados en e1 tema que se presenta en la exposición; con un sentido práctico y breve dan una explicación verbal dentro de la sala.

Medios impresos. Son folletos por medio de los cuales se informa al público en detalle acerca de lo que se exhibe, la distribución del museo y todo lo que éste contiene.

Medios técnicos. Es todo el material formado por audífonos, audiovisuales, computadoras digitales, multimedia, realidad ritual, etcétera. 


\section{$\underline{\text { Salas de exposición: }}$}

El diseño de las áreas de exposición debe ser adaptable a propuestas museográficas diversas. Se debe considerar la inclusión de piezas de gran tamaño (estelas) o piezas medianas y de pequeñas dimensiones (escultura y cerámica). Asi mismo, debe haber espacios para maquetas, dioramas o murales.

Para la exhibición de cualquier exposición, los museos cuentan con tres tipos de salas:

Salas de exposición permanente. Ameritan un estudio detallado en donde se analice el volumen y carácter de la exposición para determinar la superficie por ocupar y las dimensiones del espacio. En este análisis se considera el formato de la exposición de las piezas, la representación vertical, horizontal o en varios niveles que no debe romper la temática y debe establecer el recorrido para definir la circulación.

Sala de exposición temporal. Es el lugar donde las piezas se renuevan constantemente por lo que el manejo del espacio debe ser flexible y apto para el montaje, con fácil acceso, recorrido novedoso y separado de la sala de exposición permanente. El acondicionamiento debe ser adecuado a la colección y la ubicación e independiente de la sala de exposiciones permanentes.

Por medidas de seguridad, así como por la propia comodidad de los visitantes, las áreas de exhibición y de servicios deben estar separadas de las zonas internas y de las oficinas del museo y, de preferencia, con un solo acceso general desde el exterior, salvo en el caso del auditorio.

Salas de exposición de novedades. Sus espacios se deben diseñar con cierta flexibilidad para albergar todo tipo de objetos y espectáculos relacionados con el arte y el mundo de las novedades. Aquí resalta la museografía; las fuentes de información son breves y claras.

\section{Museología:}

El autor describe tres características esenciales de la ciencia museológica.

La importancia del museo en la vida contemporánea, ha llevado al surgimiento de una ciencia: la museología que trata acerca de la organización e instalación de los museos. 
La museología o ciencia del museo estudia la historia de los museos, su función en la sociedad, los sistemas específicos de investigación, conservación, educación y organización, así como las relaciones entre el entorno físico y la tipología.

Existen tres componentes en la museología actual: la escala íntima del contacto personal y privado con los objetos (contenido) de colección del museo; la experiencia espacial interna (continente); y, finalmente, la imagen pública del edificio y su situación como tal, un elemento dominante, ya que es la generadora de una composición urbana particular. (Plazola Cisneros, 1977, p. 341).

Uno de los principales puntos de toda institución museística lo constituyen las perfectas condiciones de exhibición al público de sus obras.

Cuando se organiza una sala de exposiciones deben valorarse distintos factores ambientales que pueden deteriorar las obras (contaminación, humedad, excesiva luminosidad, temperatura), así como la posible curiosidad del público que ha obligado a la instalación de vitrinas y cordones de separación que marcan una separación entre el observador y el objeto y evitan cualquier daño o sustracción. El enorme valor de lo expuesto ha llevado a establecer avanzados sistemas de seguridad. Todas estas medidas de protección no deben impedir en ningún momento, por otra parte, la perfecta visibilidad del material museístico.

El creciente interés de los museos por integrarse a la sociedad y explotar sus posibilidades educativas impulsó. la creación de un lenguaje propio, en el que los objetos ya no aparecieran aislados, sino acompañados de distintos documentos e innovadores pro-gresos técnicos (fotografías, paneles, audiovisuales, etcétera).

Ello debe ir unido, por supuesto, a una organización racional del espacio, luminosidad suficiente y una serie de señalizaciones y textos explicativos, que sirvan de orientación al público.

Las más innovadoras tendencias museológicas tienden a convertir al espectador en un ente activo que puede ver, hacer y tocar.

Este nuevo concepto representa estrategias de planificación basadas en un conocimiento analítico y físico de las condiciones sociales del ambiente, así como un inventario sistemático de los materiales existentes y una clara evaluación de los medios disponibles tanto en lo que se refiere a los recursos humanos como logísticos. (Plazola Cisneros, 1977, p. 341). 


\section{Museografía:}

Según el Plazola, la museografía es el elemento central en la proyección y creación de un museo, ya que conecta a la forma material edificada con las sensaciones del usuario.

La museografía es una actividad artística, cuyo dominio supone un poder creador, aparte de cultura e inventiva visuales y de conocimientos históricos y teóricos-artísticos.

En ella se considera que el museo debe ser una unidad viva y un instrumento para la popularización de la cultura, que el museo debe salir al encuentro del público, convirtiéndose en centro dinámico de la vida de la comunidad.

la museografía significa clasificar obras, adquirirlas, conservarlas y exhibirlas; su misión principal es formar parte activa de la cultura de un país determinado.

Es un arte que se desarrolla con el fin de exaltar los valores artísticos y educar la sensibilidad y la imaginación del espectador para que esté en condiciones de disfrutar y recrear el arte. Así, la museografía convierte el legado artístico en participación popular.

La museografía, por medio de los recursos estéticos, debe crear plataformas valorativas para confrontar al espectador con la obra de arte y posibilitar la vivencia artística, plenamente. (Plazola Cisneros, 1977, p. 342) Es condicionante del proyecto arquitectónico ya que hay una relación íntima entre el espacio construido y la recreación del mismo a través de los recursos museográficos

El hecho museográfico se da en el objeto que un hombre confronta; este objeto es significativo de una realidad que puede ser pasada o presente, o que es un estimulante para crear otras experiencias para el futuro. Hay en este hecho vivencias educativas, intelectuales y emocionales.

En la museografía interactúan dos lenguajes: el que se da mediante la comunicación sucesiva de signos que debe ser armónica y de fácil percepción, y el lenguaje del espacio desatado por la imagen del objeto.

\section{Diseño del proyecto}

El proceso de diseño museográfico, según el autor, consta de tres partes esenciales: arquitectura, museografía y curaduría. 
Diagrama 3.2

Proceso museográfico, movimientos, y planeación

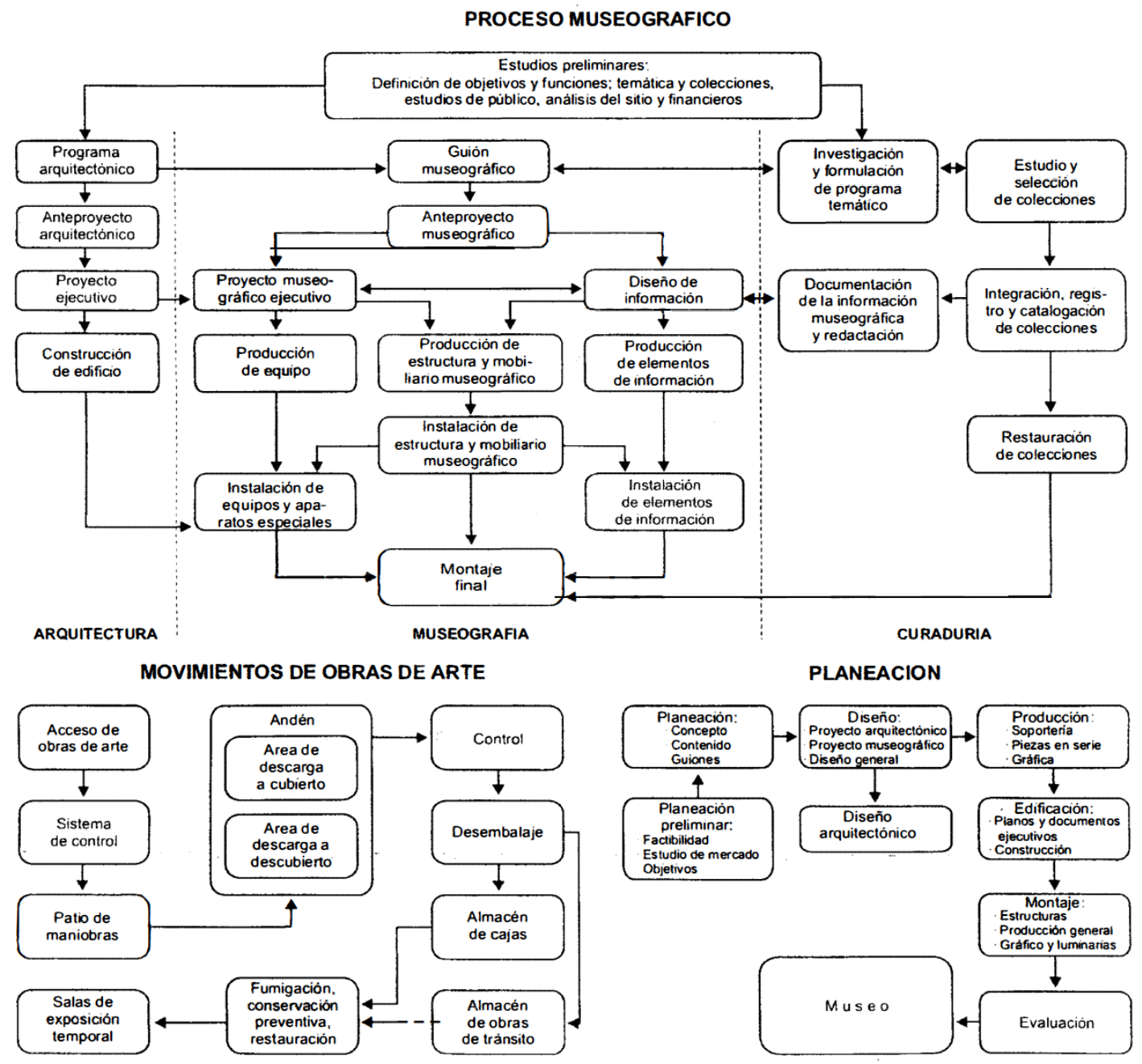

Nota: División por arquitectura, museografía y planeación

Fuente: Plazola Cisneros, 1977. p.324

El diseño trabajo realizado por el museógrafo, quien debe tener conocimientos completos de Historia Universal, Historia Nacional, Historia del Arte y de los estilos; conocimientos de diseño, comunicación, teoría del color, composición y circulación.

Para la producción hay que saber acerca de diseño de muebles y construcción en general de mobiliario en todos los materiales posibles.

El museógrafo es el encargado de la creación de las exposiciones de todo orden. 
Espacio y circulación. El espacio es el lugar donde se formaliza una muestra. La circulación es el resultado de la tensión entre lo expuesto y el espacio soporte, percibido por el visitante.

Muchas veces una muestra ha de ser visitada en un orden determinado, con el fin de poder proceder a una lectura adecuada del discurso que propone y conseguir la comprensión de la tesis que presenta. Entonces, es necesario proponer al visitante un itinerario de circulación que a menudo está condicionado por la propia disposición de las piezas y otros componentes.

No obstante, la dimensión del montaje o su complejidad, las características del edificio contenedor o la propia complejidad del tema expuesto hacen difícil, muchas veces, la realización de esta condición. En estas ocasiones, para hacer posible una lectura determinada o simplemente para mejorar las condi-ciones de visita del público, es necesario recurrir a un sistema de señales formalizado, que sea fácilmente interpretable e instalado en forma adecuada, con el fin de ofrecer a los visitantes la información pertinente.

Las circulaciones en un museo están configuradas por el guión museográfico que marca el recorrido correcto por las exposiciones. En el diseño de las circulaciones se debe prever el paso a las salas de exhibición o galerías desde las circulaciones destinadas al público en general.

La circulación depende de la forma del local y de los objetos de la exposición. Es importante que el diseño. de los recorridos no sea demasiado largo, para evitar el aburrimiento o el cansancio por parte de la audiencia.

El objeto y su situación. La presentación de objetos, sea dentro o fuera de una exposición, se realiza en una situación concreta y con un sistema de referencia más o menos limitado y coherente. Así, cada objeto adquiere todo su significado si se muestra de acuerdo con la lógica del sistema del que depende. Un mismo objeto, no obstante, puede referirse a marcos de referencia diferentes, o a ámbitos de la cultura distintos, y será sólo la forma de mostrarse, la que hará que represente o evoque unos u otros conceptos.

En este sentido, se puede decir que los objetos que se muestran tienen su significado según la situación que reproducen.

Los requisitos para una buena exposición son: que los objetos exhibidos sean importantes; las colecciones deben estar arregladas de manera adecuada; todas las piezas se mostrarán 
con buena iluminación; todos los objetos deben estar protegidos contra los agentes destructores (luz natural, fuego, humedad, polvo, insectos, roedores, vandalismo y hurto); el diseño será flexible para permitir su crecimiento. (Plazola Cisneros, 1977. p. 343)

Diagrama 3.3

Diagrama general de museos

DIAGRAMA GENERAL

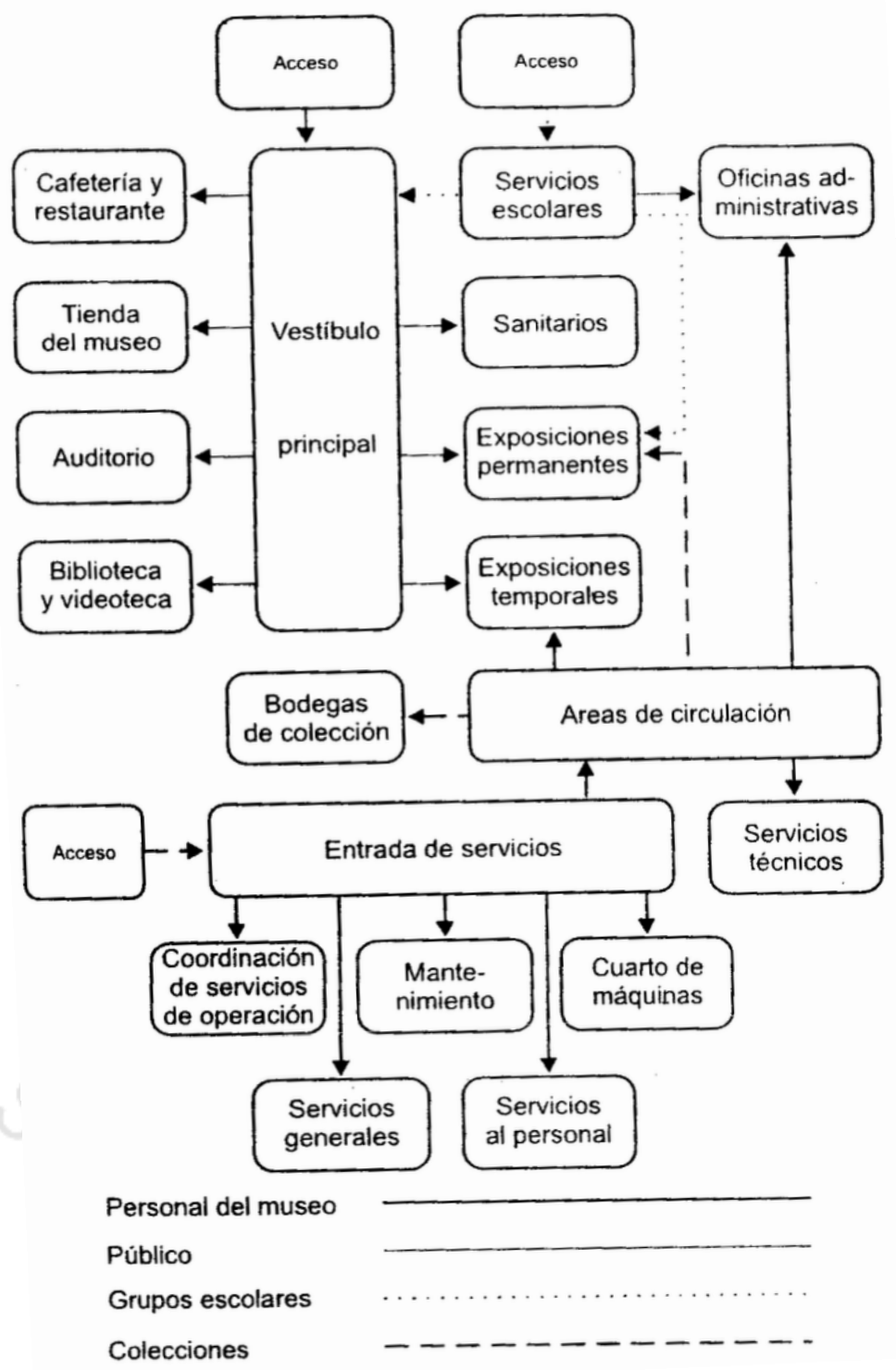

Nota: Flujos interiores de paquetes funcionales

Fuente: Plazola Cisneros, 1977. p.343 


\subsection{Glosario de terminología relevante}

Según el Reglamento Nacional de Edificaciones, se deben considerar las siguientes definiciones al momento de realizar una intervención en Bienes Culturales Inmuebles (Vásquez, 2014, p. 259):

Ambiente Monumental: Es el espacio (urbano o rural), conformado por los inmuebles homogéneos con valor monumental. También se denomina así al espacio que comprende a un inmueble monumental y a su respectiva área de apoyo monumental.

Ambiente Urbano Monumental: Son aquellos espacios públicos cuya fisonomía y elementos, por poseer valor urbanístico en conjunto, tales como escala, volumétrica, deben conservarse total o parcialmente.

Centro Histórico: Es aquel asentamiento humano vivo, fuertemente condicionado por una estructura física proveniente del pasado, reconocido como representativo de la evolución de un pueblo.

El Centro Histórico es la zona monumental más importante desde la cual se originó y desarrollo una ciudad. Las edificaciones en centros históricos y zonas urbanas monumentales pueden poseer valor monumental o de entorno.

Conjunto Monumental: Son aquellos grupos de construcciones, aisladas o reunidas, que, por razones de su arquitectura, unidad e integración al paisaje, tengan un valor histórico, científico o artístico.

Inmuebles de valor de entorno: Son aquellos inmuebles que carecen de valor monumental u obra nueva.

Inmuebles de valor monumental: Son aquellos inmuebles que sin haber sido declarados monumentos revisten valor arquitectónico o histórico declarados expresamente por el Instituto Nacional de Cultura.

Monumento: La noción de monumento abarca la creación arquitectónica aislada, así como el sitio urbano o rural que expresa el testimonio de una civilización determinada, de una evolución significativa, o de un acontecimiento histórico. Tal noción comprende no solamente las grandes creaciones sino también las obras modestas que, con el tiempo, han adquirido un significado cultural. 
Sitio Arqueológico: Todo lugar con evidencias de actividad social con presencia de elementos y contextos de carácter arqueológico histórico tanto en la superficie como subyacente.

Zonas Arqueológicas Monumentales: Son los conjuntos arqueológicos cuya magnitud los hace susceptibles de trato especial en lo que a investigación se refiere, pues su fisonomía debe conservarse por las siguientes razones:

a) Por poseer valor urbanístico de conjunto;

b) Por poseer valor documental histórico, artístico y/o un carácter singular; y

c) Por contener monumentos y/o ambientes urbano monumentales.

Zona Urbana Monumental: Son aquellos sectores o barrios de una ciudad cuya fisonomía debe conservarse por cualquiera de las razones siguientes:

a) Por poseer valor urbanístico de conjunto;

b) Por poseer valor documental histórico y/o artístico; y c) Porque en ellas se encuentra un número apreciable de monumentos o ambientes urbano monumentales.

\subsection{Instituciones afines}

\subsubsection{Ministerio de Cultura}

El ministerio de Cultura es un organismo del Poder Ejecutivo que tiene comptencia exclusiva y excluyente sobre todos los aspectos culturales del país. Posee atribuciones y funciones sobre las siguientes áreas programáticas (Ministerio de Vivienda, 2016) :

1. Patrimonio cultural de la nación, material e inmaterial

2. Creación cultural contemporánea y artes vivas

3. Gestión cultural e industrias culturales

4. Pluralidad étnica y cultural de la nación

\subsubsection{Ministerio de Vivienda (Reglamento Nacional de Edificaciones)}

Vivienda tiene como misión mejorar las condiciones de vida de la población peruana facilitando su acceso a una vivienda adecuada y a los servicios básicos como agua y saneamiento, propiciando el ordenamiento, crecimiento, conservación, mantenimiento y protección de los centros de población y sus áreas 
de influencia, fomentando la participación de las organizaciones de la sociedad civil y de la iniciativa e inversión privadas. (Ministerio de Vivienda, 2002)

El Reglamento Nacional de Edificaciones (RNE), elaborado por dicho ministerio, es un conjunto de normas de orden técnico que regula el diseño sobre habilitaciones urbanas y edificaciones. Además, juega un papel vital en que las reglas sean claras en bien de los habitantes, el medio ambiente y la propia edificación. ${ }^{19}$

\subsubsection{UNESCO}

La Organización de las Naciones Unidas por la Educación, Ciencia y la Cultura (UNESCO por sus siglas en inglés) fue creada en 1945 para cimentar la paz lograda luego de dos guerras mundiales a través de la solidaridad moral e intelectual de la humanidad. Entre las labores de la UNESCO, la que concierne a esta investigación es:

Que haya un entendimiento intercultural mediante la protección del patrimonio y el apoyo a la diversidad cultural. La UNESCO creó el concepto de 'Patrimonio Mundial' para proteger lugares de un valor universal excepcional. (United Nations Educational, Scientific and Cultural Organization, 2010)

\subsubsection{ICOMOS}

El Consejo Internacional de Monumentos y Sitios (ICOMOS por sus siglas en inglés) es una organización no gubernamental, creada en 1965 como resultado de la Carta de Venecia y ligada la UNESCO. Dicha institución se encarga de la conservación y la protección de monumentos, de conjuntos y de sitios de patrimonio cultural. Adicionalmente, promueve la teoría, la metodología y la puesta en valor de dichos monumentos. (International Council on Monuments and Sites, 2012).

\subsection{Normativa de intervención en el Centro de Lima}

\subsubsection{RNE}

Según el artículo 30 de la norma A-140 del Reglamento Nacional de Edificaciones:

Los proyectos de intervención en bienes culturales inmuebles, para ser sometidos a su aprobación deberán contener la siguiente información (Vásquez, 2014, p. 263):

\footnotetext{
19 Definición obtenida del Ingeniero Oscar Vásquez Bustamente, en su publicación Reglamento Nacional de Edificaciones (2014).
} 


\section{a) Estudio Histórico:}

- Planos anteriores

- Fotografías o grabados anteriores del inmueble - Documentos de propiedad.

\section{b) Levantamiento del estado actual:}

- Plano de las fachadas del perfil urbano de ambos frentes de la calle donde se ubica el inmueble.

- Fotografías del exterior y del interior del inmueble

- Planos de plantas, cortes y elevaciones. Indicación de materiales de pisos, techos y muros, reseñando su estado de conservación. Indicación de intervenciones efectuadas al inmueble.

- Planos de instalaciones eléctricas y sanitarias, indicando el estado de conservación.

- Memoria descriptiva de las funciones actuales y de los componentes formales.

\section{c) Zonificación:}

La zonificación define y limita lo que se puede hacer en el área a intervenir. Existen distintos tipos de zonas, con distintos alcances y atribuciones.

\subsubsection{Recomendaciones ICOMOS ${ }^{20}$}

Según el documento de "Los principios para el análisis, conservación, y restauración de las estructuras del patrimonio arquitectónico" ratificado en Zimbabwe en octubre de 2003:

Las estructuras del patrimonio arquitectónico, tanto por su naturaleza como por su historia (en lo que se refiere al material y a su ensamblaje), están sometidas a una serie de dificultades de diagnóstico y restauración, que limitan la aplicación de las disposiciones normativas y las pautas vigentes en el ámbito de la construcción. Ello hace tan deseable como necesario formular unas recomendaciones que garanticen la aplicación de unos métodos racionales de análisis y restauración, adecuados a cada contexto cultural. (14a Asamblea General del ICOMOS, 2003, pp. 1)

En este documento se detallan recomendaciones y sugerencias sobre la intervención y restauración de Monumentos Históricos (ver anexo n. 2)

\footnotetext{
20 ICOMOS: Concejo Internacional de Monumentos y Sitios
} 


\subsection{Conclusiones parciales}

A través de los años han existido distintas maneras de conservar, intervenir e inclusive reusar los edificios. Luego de haber pasado por varias experiencias, el consenso mundial se inclina por una intervención responsable, honesta con su origen y sobre todo que complemente la pieza arquitectónica original, que no la encubra ni imite, sino que colabore a crear un nuevo espacio que potencie la función del mismo.

Por otro lado, como hace evidente el proceso evolutivo de tipologías museológicas, en la actualidad se trata de interferir con la naturaleza lo menos posible, siempre dejándola como protagonista del conjunto. Lo mismo debe ocurrir en el planteamiento del diseño de la ampliación del Museo de Arte de Lima; el Parque de la Exposición, como pulmón verde de la ciudad debe ser recuperado. El nuevo edificio debería ser un Museo Paisaje. Adicionalmente, para poder realizar una intervención en el Centro de Lima se deben tener en cuenta las definiciones expuestas anteriormente y además recabar la información requerida para la presentación del proyecto. La normativa nacional y recomendaciones internacionales deben respetarse.

Asimismo, la propuesta debe responder a las teorías planteadas como más adecuadas para el proyecto en cuestión, y debe ser una pieza que complemente y ponga en valor el MALI. 


\section{CAPÍTULO IV: MARCO OPERATIVO}

En este capítulo nos concentraremos en el estudio de los casos análogos internacionales y nacionales para encontrar posibles características de diseño que se puedan utilizar como referencia para elaborar el proyecto de arquitectura de la ampliación del Museo de Arte de Lima.

Primero se analizarán casos de intervenciones puntuales de puesta en valor y adecuación al uso de edificios de valor histórico en el Perú.

Luego, entre los proyectos internacionales, se presentará información general, que incluirá planos, fotografías, porcentaje de áreas públicas y privadas, autor, ubicación y año de construcción. Las obras a tratar serán la ampliación de Louvre, el museo Kolumba, el museo Judío de Berlín y el Centro Cultural de la Moneda. En seguida, se hará un análisis comparativo a partir de las variables: función, contexto, forma, materialidad, usuario, programas, relación entre espacios públicos/privados, libres/ocupados, tecnología e impacto social.

\subsection{Supuesto básico de investigación}

La investigación de proyectos de intervención en edificios de interés patrimonial dentro de un contexto histórico, en donde también se incluya al MALI, es vital para la definición de ideas generales de diseño que el proyecto de ampliación de dicho museo. A continuación, se mencionan las variables que participarán:

$\rightarrow$ Variables independientes: las intervenciones análogas

$\rightarrow$ Variable interviniente: el contexto del histórico del Parque de la Exposición

$\rightarrow$ Variables dependientes: el programa arquitectónico resultante del análisis.

\subsection{Intervenciones locales}

Existen proyectos en el Perú cuyo objetivo inicial era similar al del proyecto de esta investigación: 


\subsubsection{Museo de Arte de Lima (1872)}

\section{Puesta en Valor}

En 1956 se elaboró un proyecto integral de restauración y puesta en valor del edificio, lo que contribuyó a que en 1961 se entregará la primera etapa y se pueda abrir el museo finalmente al público (Museo de Arte de Lima, 2016).

Figura 4.1

Fachada norte del MALI en los años 60

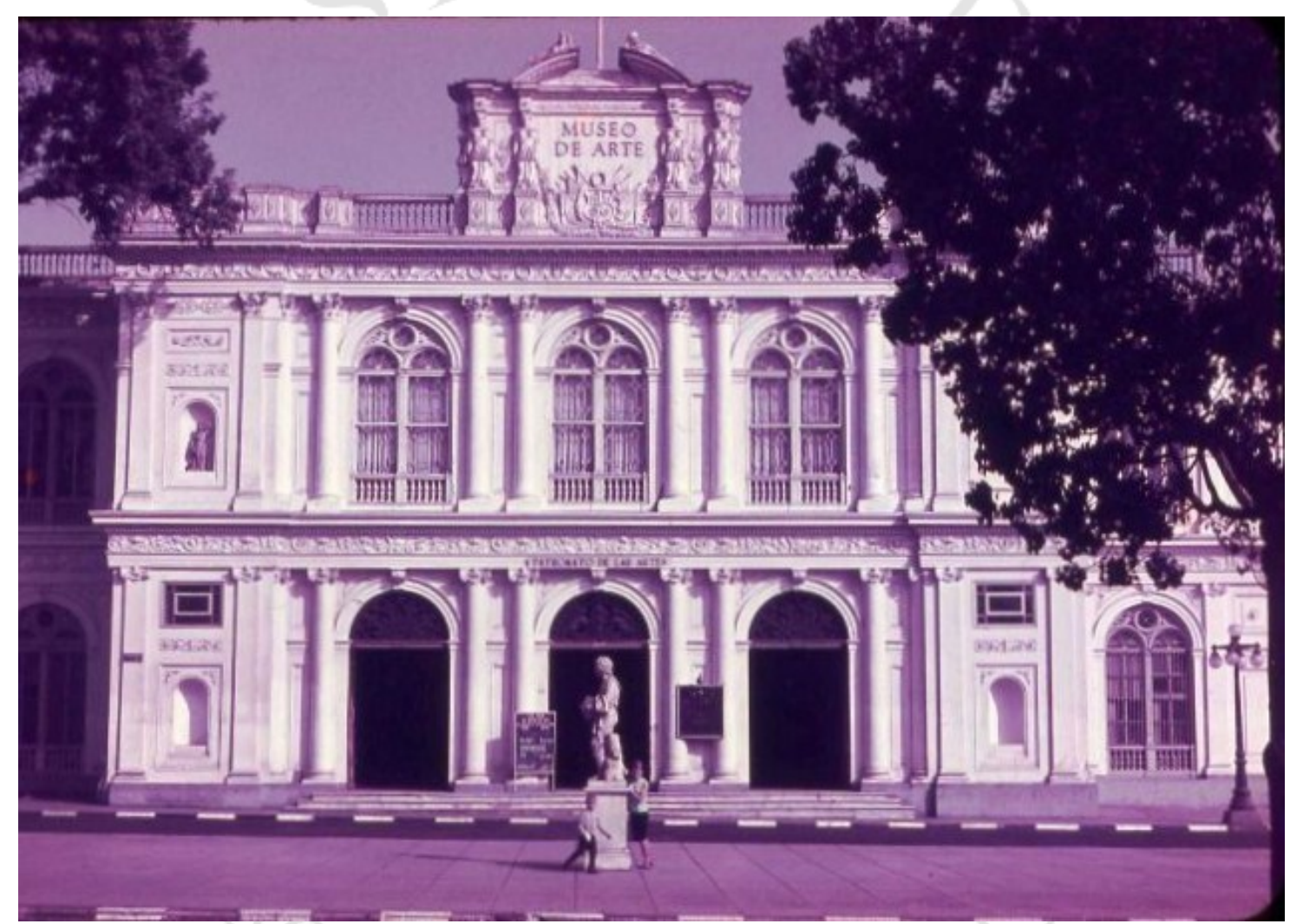

Fuente: Museo de Arte de Lima, 2016. Archivo.

\section{Adecuación al uso}

Hacia finales de la década de los 90 se interviene un espacio al lado del museo, en la esquina de la Av. Paseo Colón y Wilson. El Arq. Ortiz de Zevallos fue el encargado del diseño en el que se generó un espacio hundido con talleres educativos y una especie de anfiteatro. La obra se entregó finalmente en el año 2000. 
Figura 4.2

Plaza hundida frente a la fachada oeste del MALI

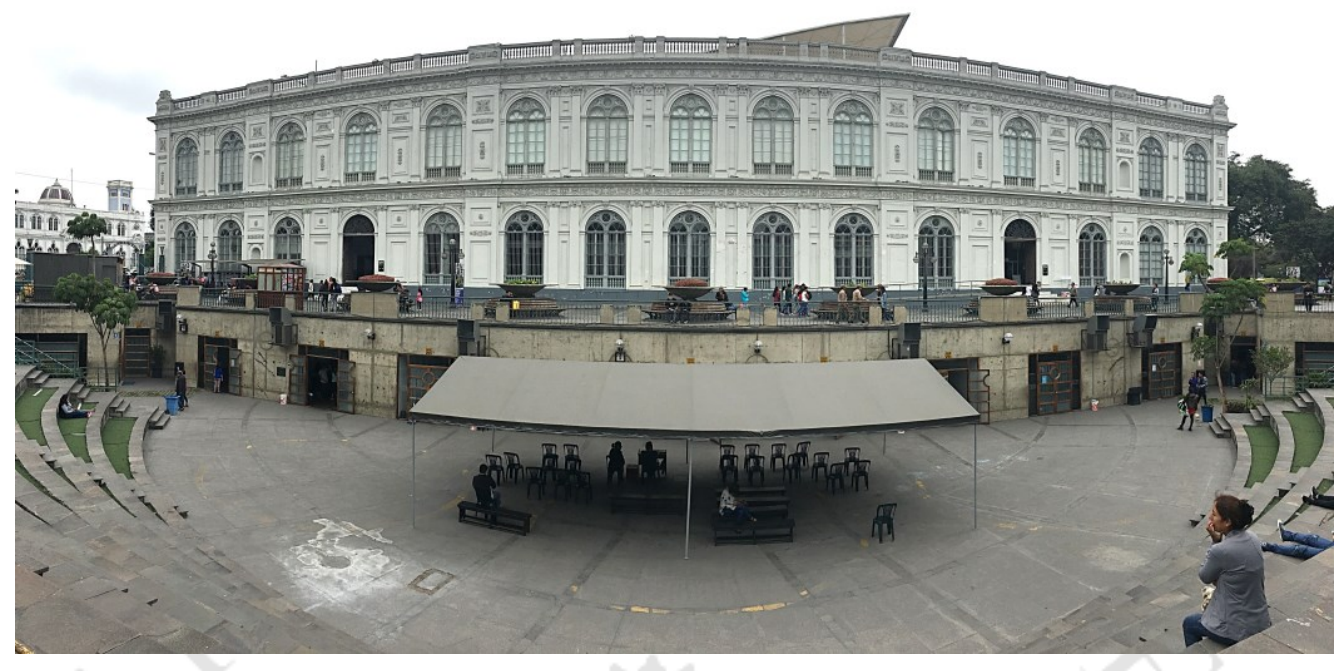

Nota: Imagen panorámica de autor de ingreso a talleres subterráneos a través de anfiteatro hundido.

Fuente: Elaboración propia, 2017

En el año 2010, y en el área antiguamente designada para exposiciones temporales, se instala un auditorio diseñado por el Arq. Emilio Soyer ${ }^{21}$. Este recinto cuenta en la actualidad con los últimos avances de iluminación, proyección y acústica.

Figura 4.3

Anfiteatro interior

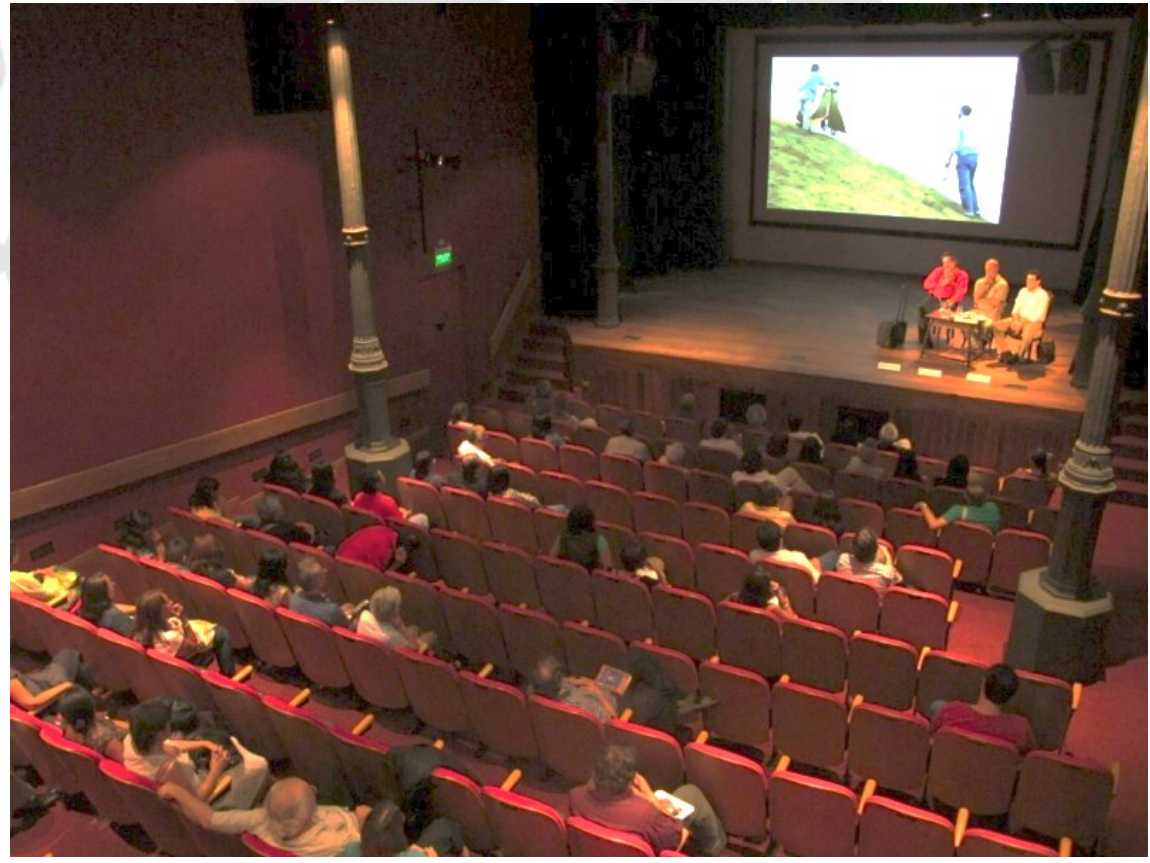

Fuente: Museo de Arte de Lima, 2016. Archivo.

\footnotetext{
${ }^{21}$ Emilio Soyer: arquitecto peruano representante del modernismo nacional (Lima, 28 de octubre 1936).
} 
En la actualidad, el segundo piso está aún siendo restaurado para volver a exhibir su colección permanente.

\subsubsection{Museo Convento de Santo Domingo - Qorikancha (Cusco) (siglo XVI)}

\section{Adecuación al uso}

En la época precolombina, este fue el mayor templo de toda la nación Inca. Luego de la conquista española, Juan Pizarro, hermano de Francisco Pizarro, dona al morir el templo a los dominicos, quienes deciden levantar un convento sobre el edificio existente. En este caso, la intervención fue sumamente invasiva, y se perdieron varios muros y todo el techado original; incluso se taparon los muros de piedra con yeso para ocultar cualquier rastro de sus antiguos ocupantes. Se dio prioridad al uso de la orden religiosa que iba a ocupar el espacio sin tomar en cuenta el valor patrimonial del edificio original.

\section{Puesta en valor}

Ya en el siglo XX y con la ayuda del $\mathrm{INC}^{22}$, luego del terremoto de Cusco de 1950, se buscó restaurar el Qorikancha por completo. Se descubrieron varios muros incas que habían estado cubiertos por muchos años y se dejaron al descubierto, así como también se restauraron pinturas murales de la época colonial. Además, se hicieron intervenciones mínimas para así facilitar la visita y la circulación dentro del recinto. (Proyecto Koricancha, 2012). Hasta el día de hoy, el proyecto de restauración y mantenimiento está a cargo de la arquitecta Marisol Zumaeta Aurazo.

Se puede observar cómo se han generado coberturas metálicas con grandes vanos vidriados para proteger y preservar los muros incas. Además, se ha mantenido la configuración espacial de la ocupación española por el valor histórico de intervención que representa.

\footnotetext{
${ }^{22}$ Instituto Nacional de Cultural (actual Ministerio de Cultura).
} 
Figura 4.4

Interior del Qorikancha

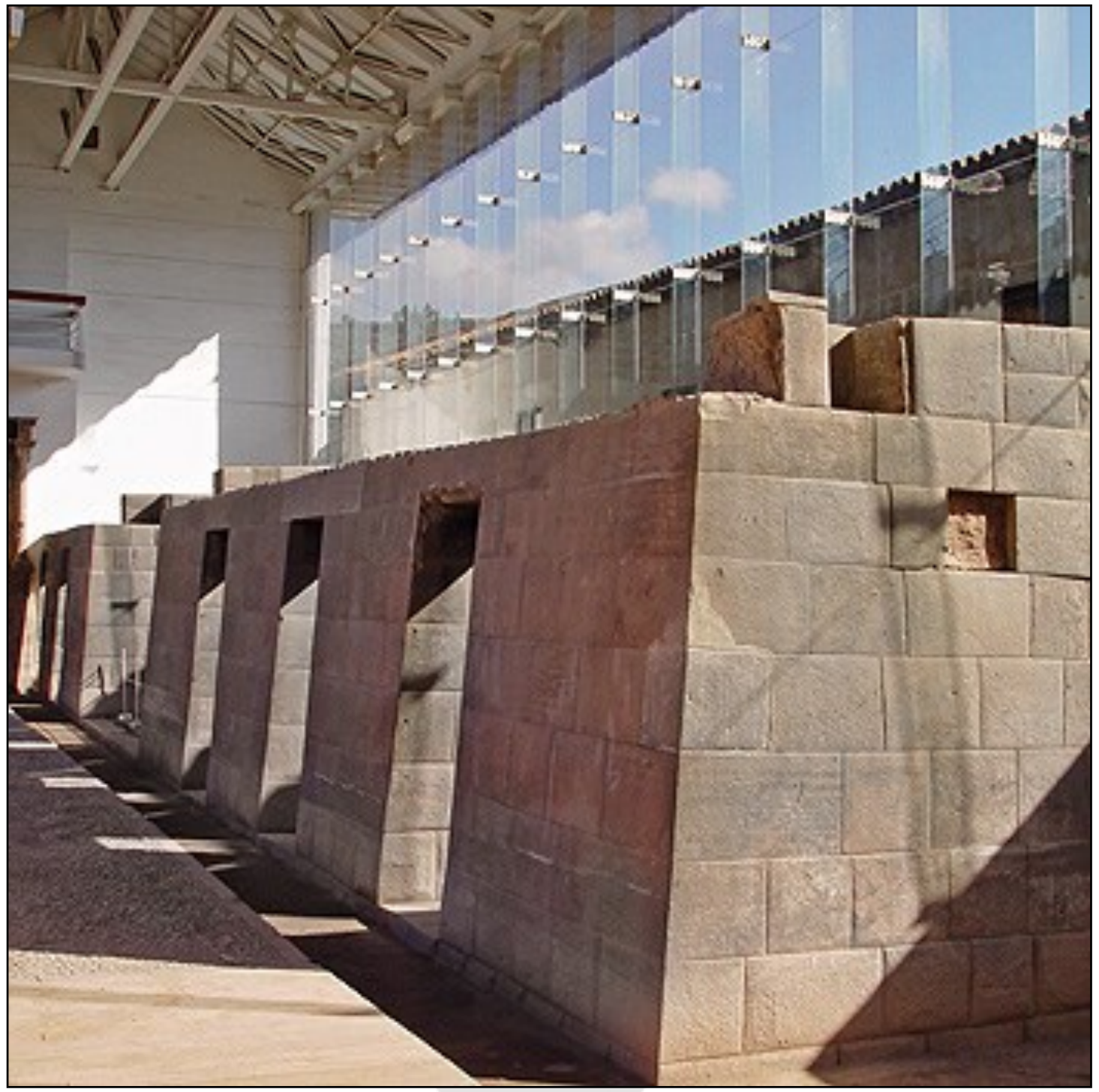

Nota: Foto del interior del museo en donde se observan los tres periodos arquitectónicos. Fuente: Portal Machu Picchu, 2012. Museo Convento de Santo Domingo.. Recuperado de https://goo.gl/Uxhchv

\subsubsection{Museo de Arte Precolombino (Cusco) (siglo XVII)}

\section{Puesta en valor}

Esta antigua casona, que durante el siglo XVII sirvió como convento de Santa Clara, fue adquirida por el Banco Continental en 1981 a los descendientes de Luis de Cabrera y la Cerda. En el 2002, y en esfuerzo conjunto con el Museo Larco, empiezan un proyecto de puesta en valor del edificio con el diseño de recuperación del arquitecto Samanez. Es así 
como en el 2003 se inaugura el Museo de Arte Precolombino con piezas de la Colección Larco.

Figura 4.5

Patio central con intervención de estructura metálica

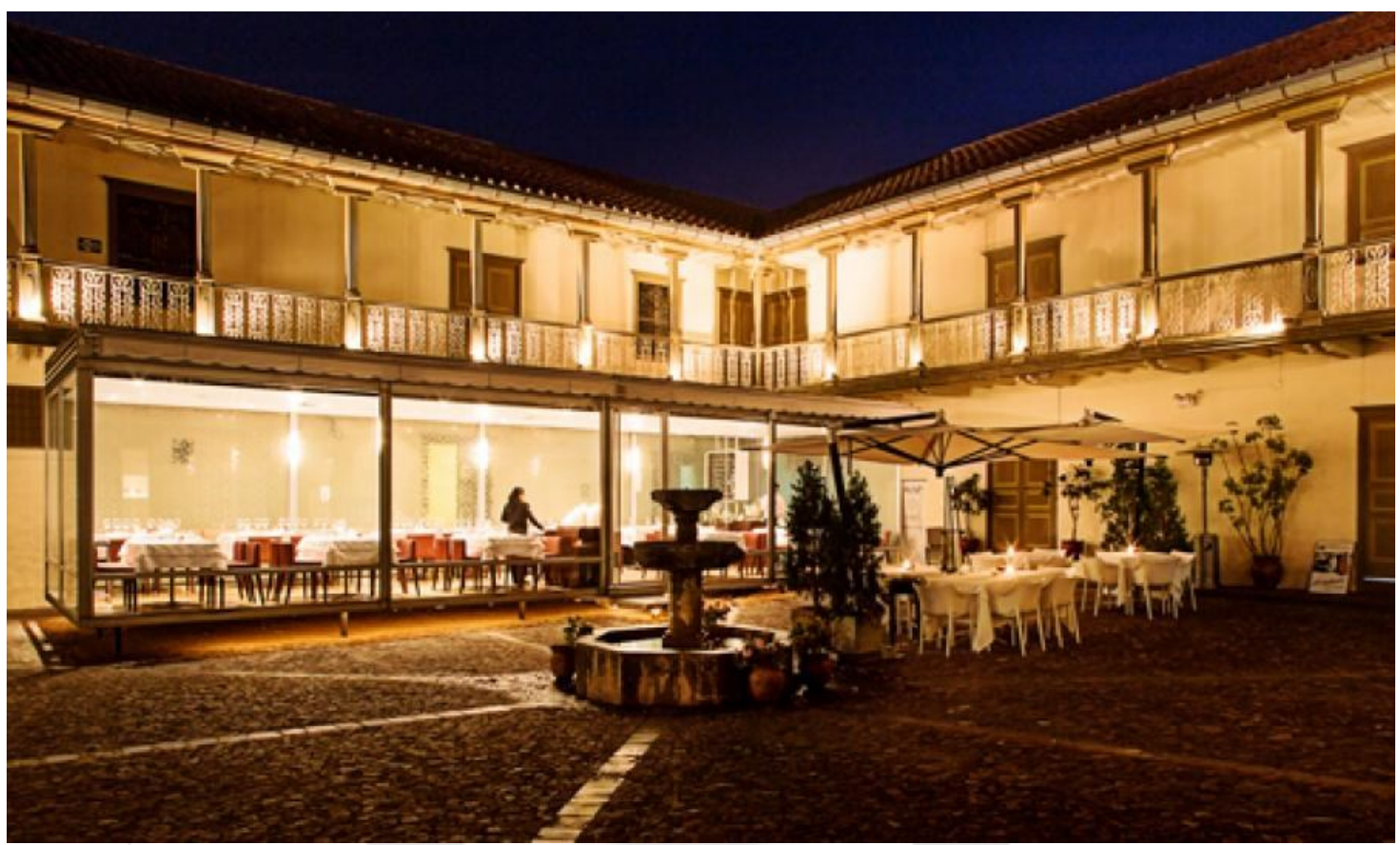

Fuente: In Bound Perú, 2015. Map Cafe. Recuperado de https://goo.gl/uNZuP7

\section{Adecuación al uso}

Si bien gran parte de la casa ha sido mantenida en su estado original, existe una intervención del Arq. Jordi Puig ${ }^{23}$ en el patio central a manera de terraza techada que se posa ligeramente sobre una estructura metálica. (Museo de Arte Precolombino, 2012). Esta extensión sirve para ampliar el espacio de la cafetería interior y así adecuar el lugar a las necesidades de los visitantes. Este volumen puede ser removido sin afectar el predio colonial. Se observa que el ritmo de las columnas guarda armonía con las columnas de la segunda planta del edificio. Por otro lado, la transparencia de esta intervención permite la visualización del interior del predio histórico sin ningún inconveniente.

A continuación, se analizarán 4 proyectos internacionales referidos al tema de investigación:

\footnotetext{
${ }^{23}$ Jordi Puig: arquitecto peruano nacido en Piura. Reconocido por numerosos proyectos comerciales y de vivienda.
} 


\subsection{Proyectos análogos}

\subsubsection{Museo Judío de Berlín}

Ubicación: Berlín, Alemania

Arquitecto: Libeskind

Año de intervención: 1992-1999

El Museo Judío de Berlín, originalmente albergado en el edificio contiguo del siglo XVIII de estilo barroco, es una muestra del deconstructivismo alemán. Está cubierto de placas de zinc y propone una simbiosis entre la arquitectura y el contenido. El diseño es llamado "between the lines"(entre líneas), y es en esta forma que la historia judía se va narrando por el cruce de dos ejes, que al unirse forman "voids" (vacíos). El arquitecto plasma la dicha narrativa de manera sensorial y reflexiva. (Museo Judío de Berlín, 2016).

El programa de la ampliación y renovación del Museo Judío de Berlín incluye:

- Salas de exhibición

- Talleres

- Salas de debate

- Salas temporales o multiusos.

- Espacios abiertos para la reflexión y meditación.

Tabla 4.1. Tipo de espacio y porcentaje

\begin{tabular}{|c|c|}
\hline Tipo de espacio & Porcentaje \\
\hline Público & 25 \\
\hline Semipúblico & 45 \\
\hline Privado & 30 \\
\hline
\end{tabular}

Nota: Tabla de tipos de espacio y porcentajes de espacios públicos, semipúblicos y privados.

Fuente: Elaboración propia, 2010

- Área libre: $65 \%$ de superficie original

- Área ocupada por proyecto: $35 \%$ de superficie original 


\section{Imágenes del proyecto:}

Figura 4.6

Sala de exhibición en la segunda planta

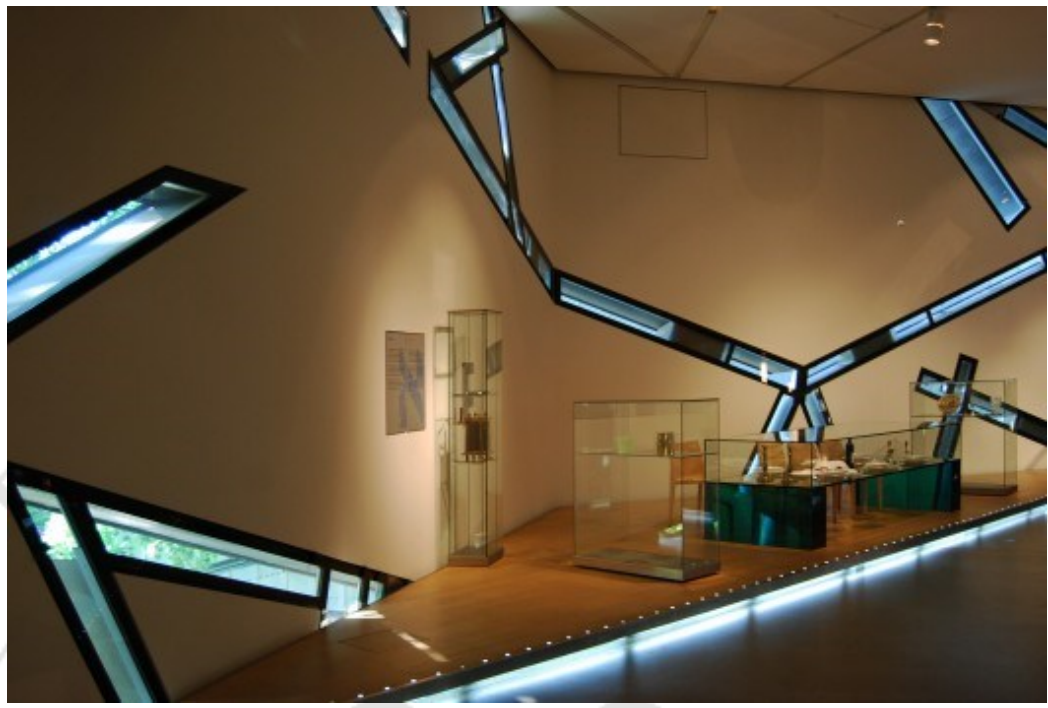

Nota: Imagén interior

Fuente: Archdaily, 2015. Museo Judio, Berlín / Daniel Libenskind.

Recuperado de https://goo.gl/rgUZ9p

Figura 4.7

Exterior y maqueta de proyecto

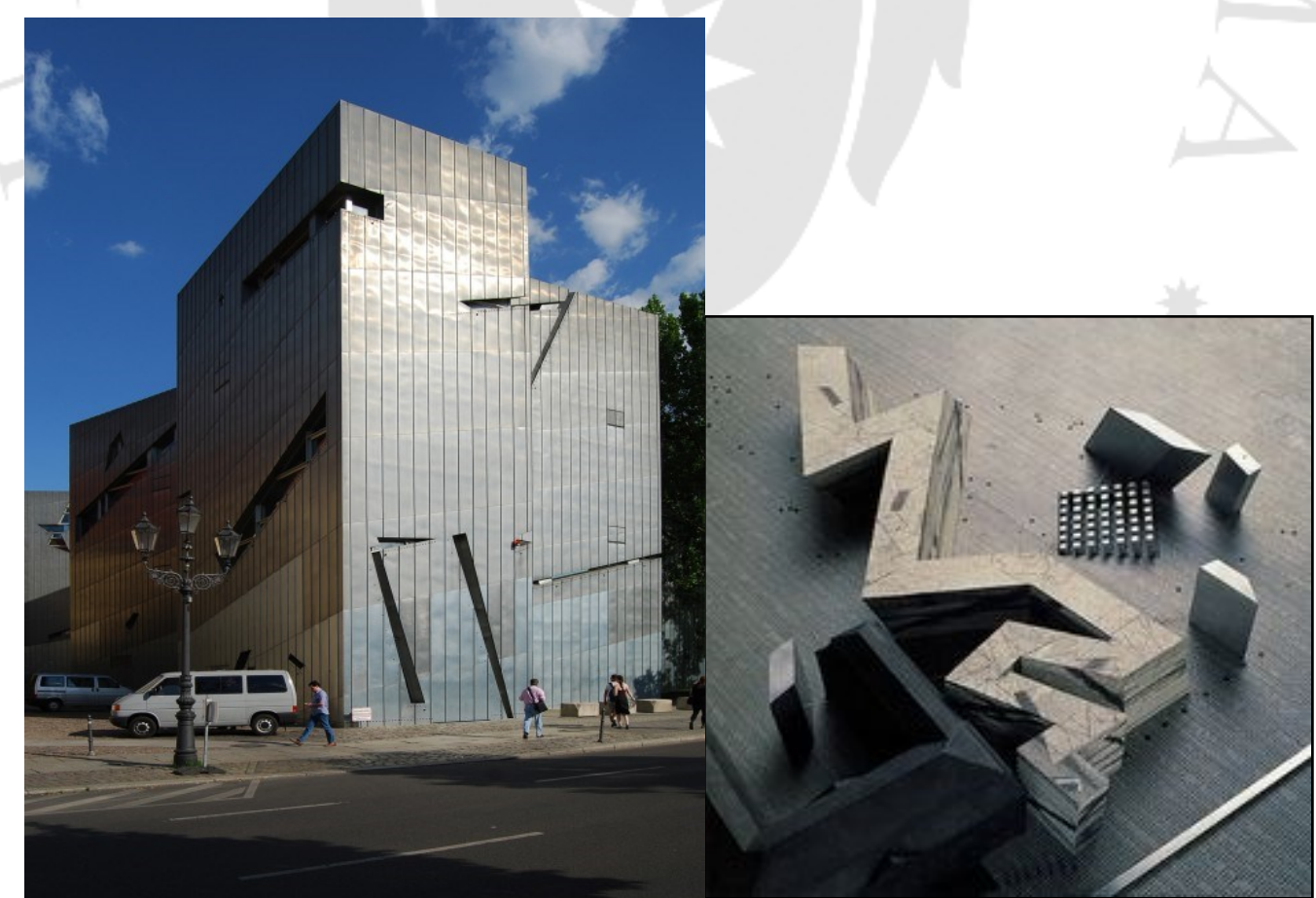

Nota: Imagen exterior y de modelo a escala

Fuente: Archdaily, 2015. Museo Judio, Berlín / Daniel Libenskind. Recuperado de

https://goo.gl/rgUZ9p 


\section{Plantas esquemáticas:}

Figura 4.8

Planta de primer piso

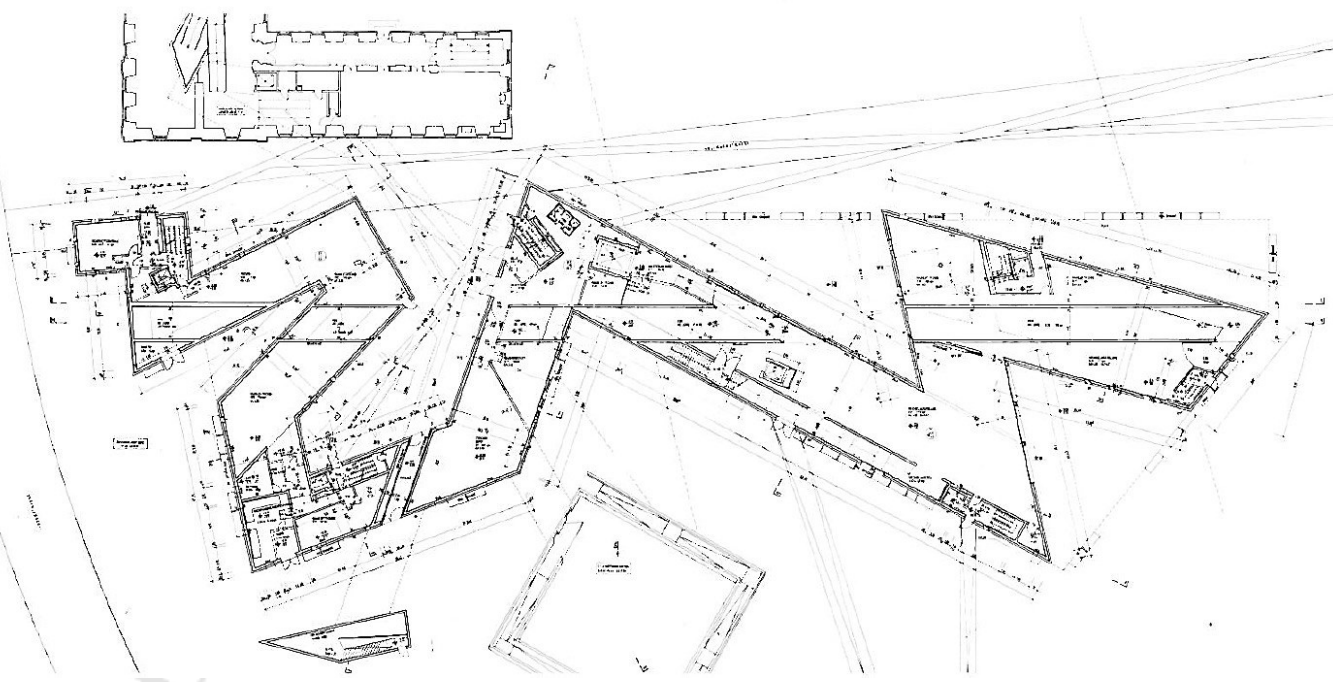

Nota: Planta esquemática

Fuente: Archi DIAP, 2014. Museo Judío de Berlín. Recuperado de https://goo.gl/3BT2X4

Figura 4.9

Planta de sótano

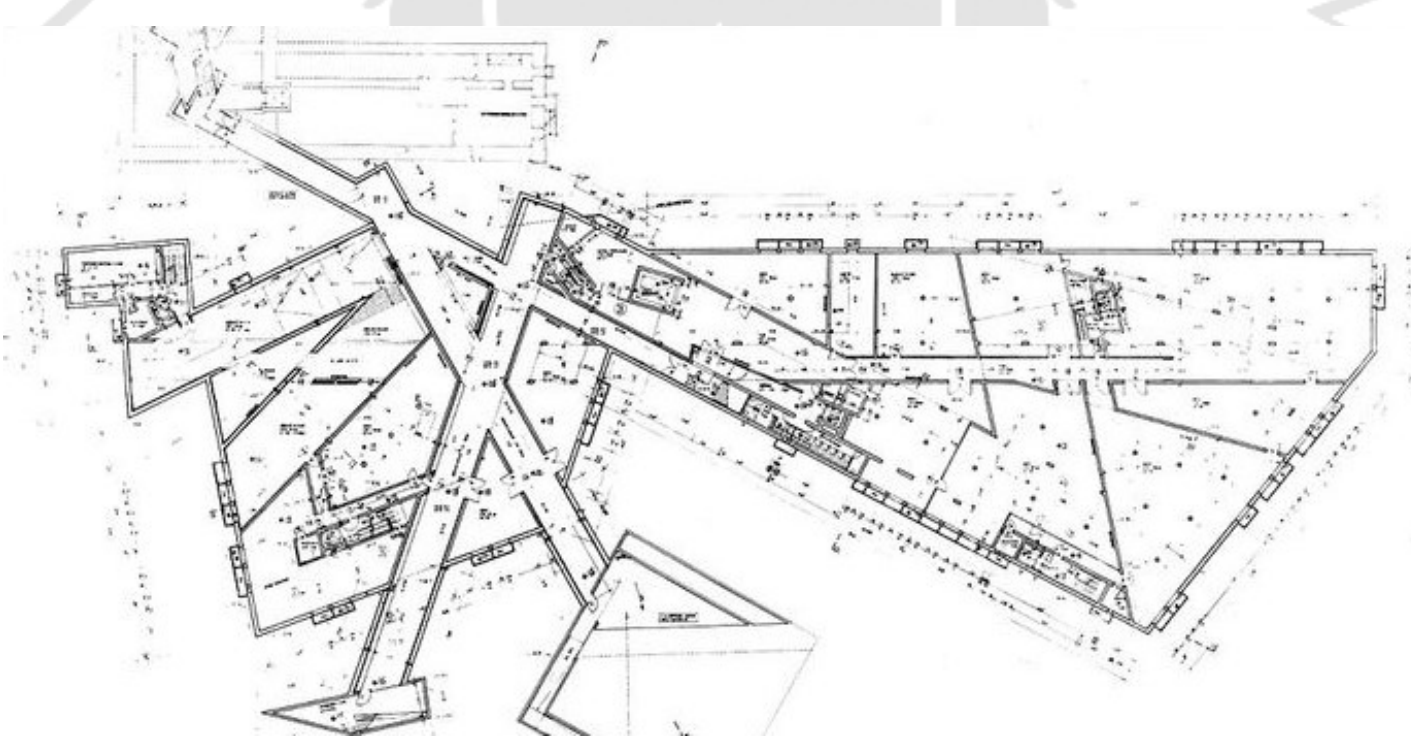

Nota: Planta esquemática

Fuente: Archi DIAP, 2014. Museo Judio de Berlin. Recuperado de https://goo.gl/3BT2X4 


\subsubsection{Museo Louvre}

Ubicación: Paris, Francia

Arquitecto: Ieoh Pei

Año de intervención: 1984-1989

Paris ha sido una ciudad de pirámides desde la época de Napoleón, que quedó fascinado con ellas desde sus travesías por Egipto. La pirámide de cristal propuesta por Pei hace alusión este periodo, y su ligereza estructural contrasta con la solidez del Palacio de Louvre. Esta es únicamente la punta del iceberg, ya que el proyecto incluyó la creación de un gran nivel subterráneo. (The Guardian, 2010)

El programa de la amplación y renovación del Museo Louvre incluye:

- Salas de exhibición

- Salas temporales o multiusos.

- Tiendas

- Cafeterías

- Espacios abiertos para la ciudad / restauración de la plaza

- Depósitos y oficinas

Tabla 4.2. Tipo de espacio y porcentaje

\begin{tabular}{|c|c|}
\hline Tipo de espacio & Porcentaje \\
\hline Público & 50 \\
\hline Semipúblico & 30 \\
\hline Privado & 25 \\
\hline
\end{tabular}

Nota: Tabla de tipos de espacio y porcentajes de espacios públicos, semipúblicos y privados.

Fuente: Elaboración propia, 2015

- Área libre: $70 \%$ de superficie original

- Área ocupada por proyecto: $30 \%$ de superficie original 


\section{Imágenes del proyecto}

Figura 4.10

Fachada nocturna

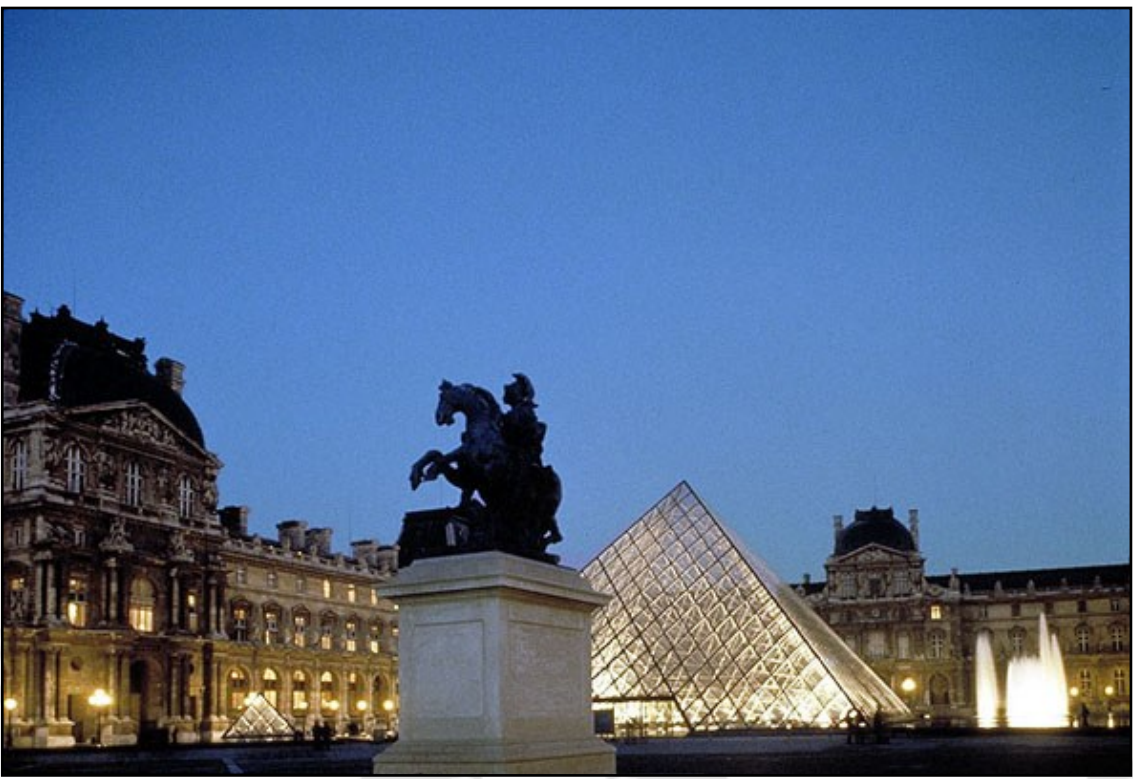

Nota: Exteriores del museo por la noche

Fuente: Moleskin Arquitectónico, 2009. I'm Pei y el Museo del Louvre. Recuperado de https://goo.gl/ciJtn5

Figura 4.11

Hall principal

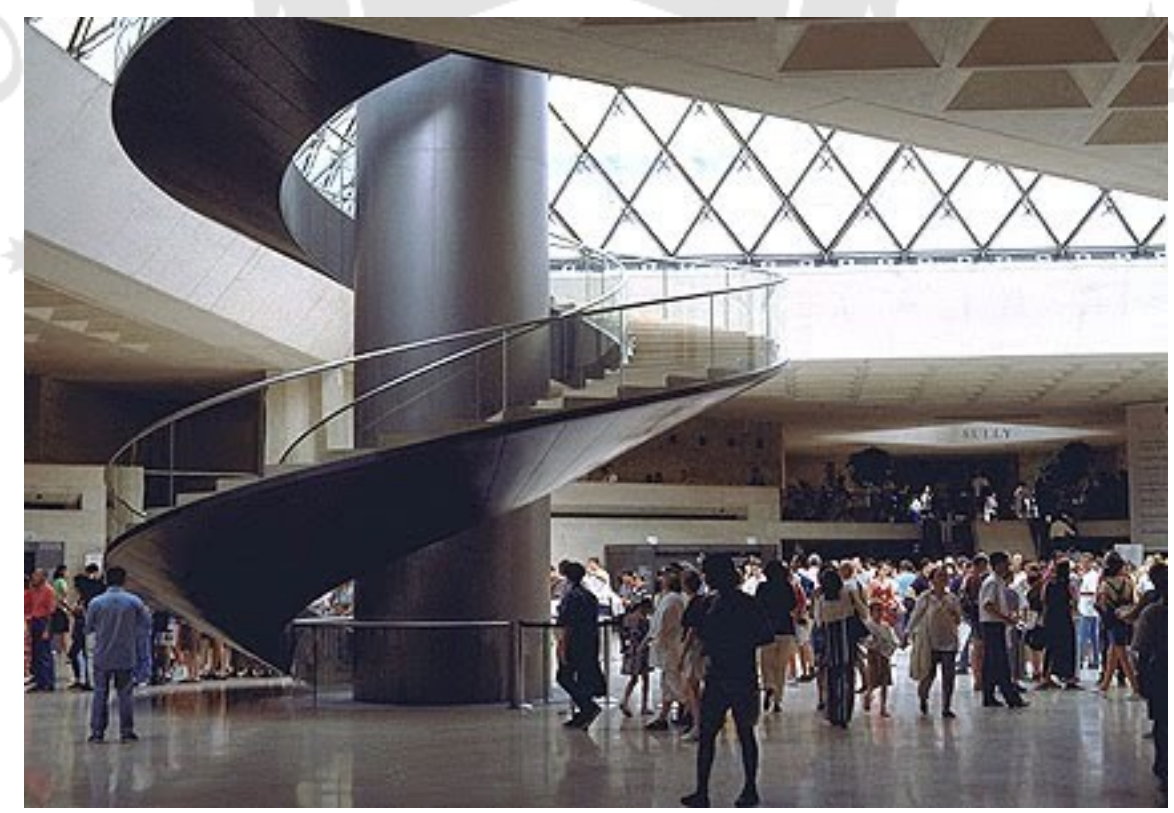

Nota: Interior durante el día del Hall Principal

Fuente: Moleskin Arquitectónico, 2009. I’m Pei y el Museo del Louvre. Recuperado de https://goo.gl/ciJtn5 


\section{Plantas esquemáticas}

Figura 4.12

Primer piso del museo Louvre

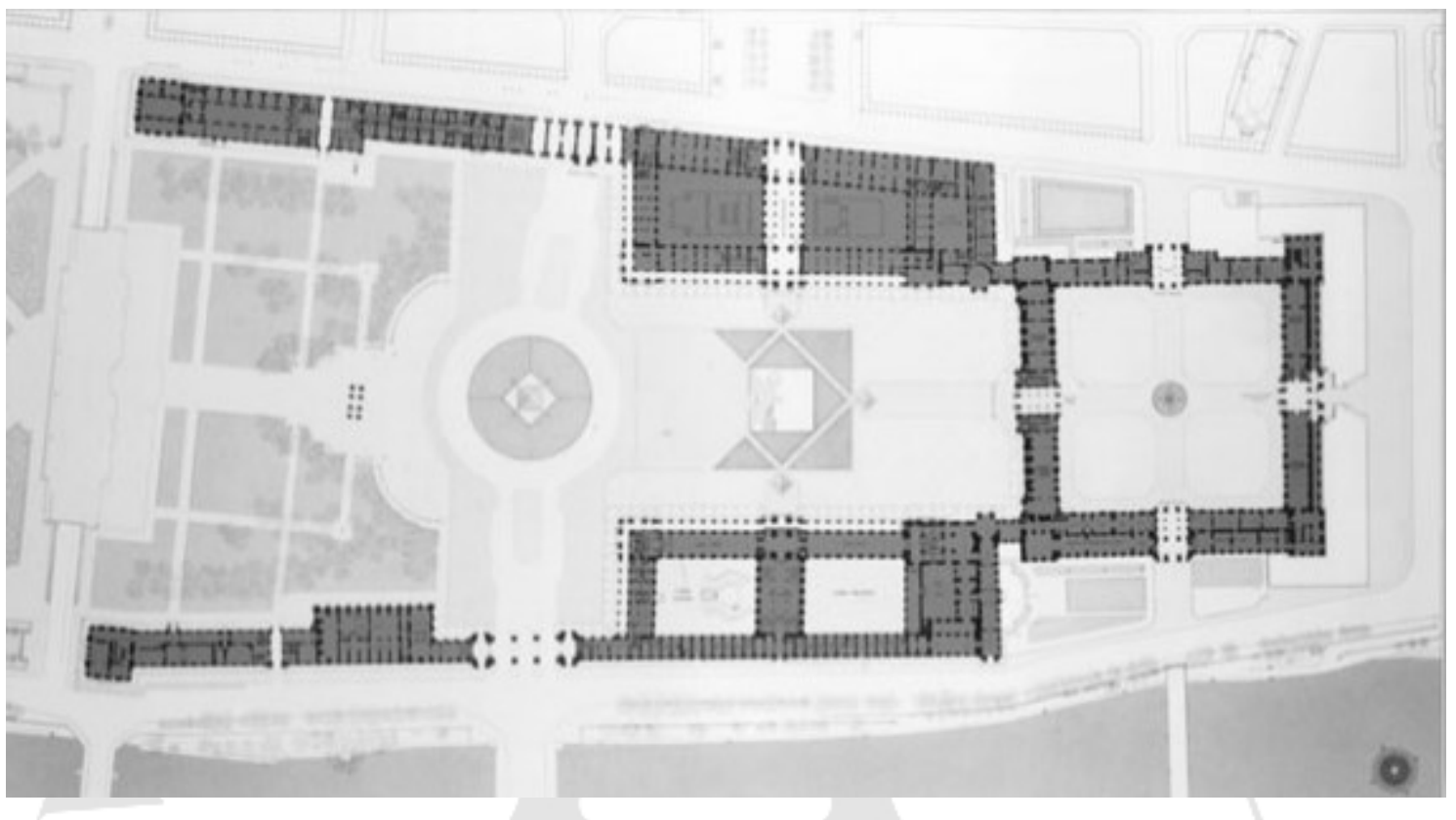

Nota: Planta esquemática

Fuente: Moleskin Arquitectónico, 2009. I'm Pei y el Museo del Louvre. Recuperado de https://goo.gl/ciJtn5

Figura 4.13

Primer sótano del museo Louvre

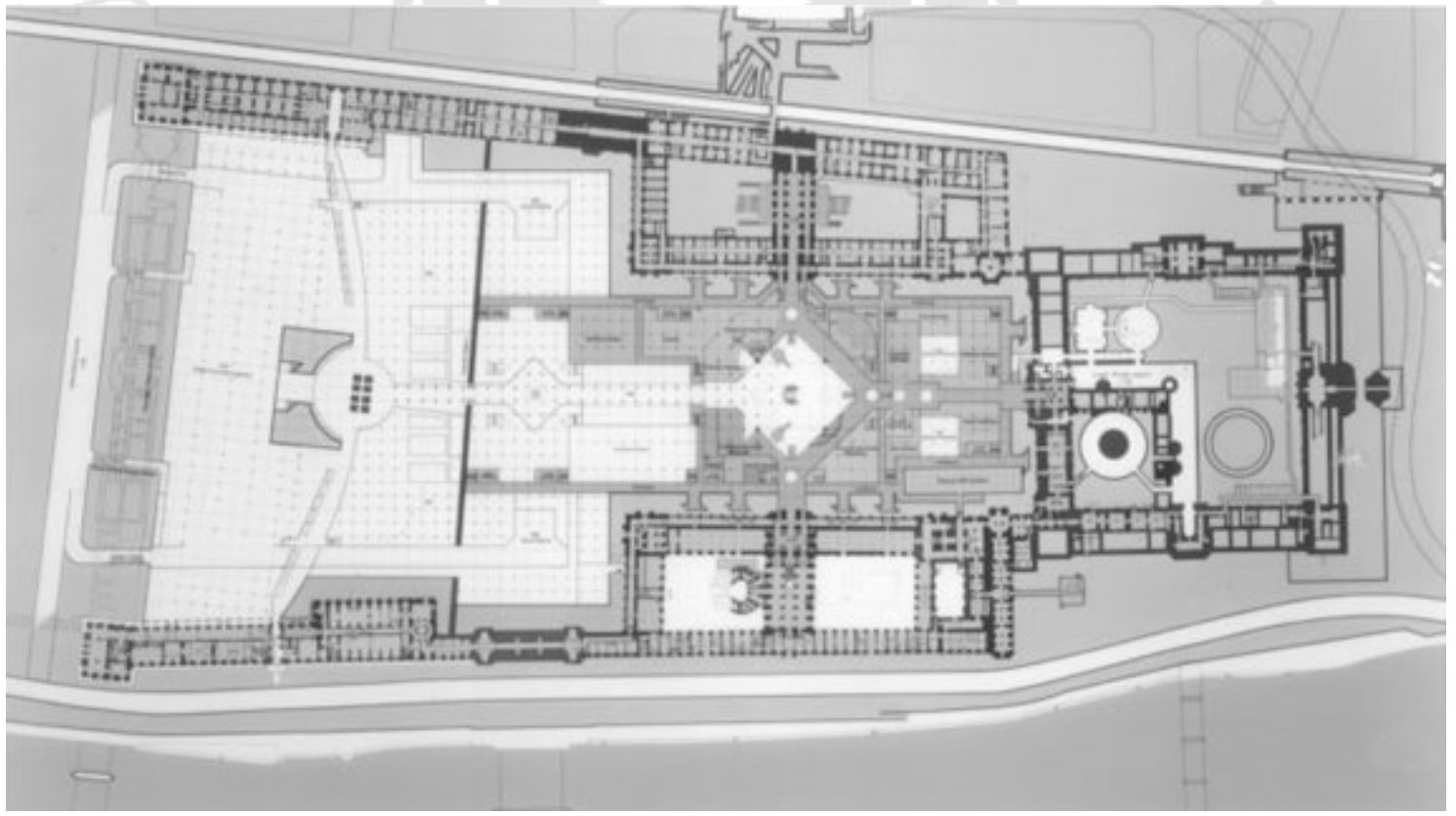

Nota: Planta esquemática

Fuente: Moleskin Arquitectónico, 2009. I'm Pei y el Museo del Louvre. Recuperado de https://goo.gl/ciJtn5 


\section{Cortes esquemáticos}

Figura 4.14

Corte transveral del proyecto de Pei

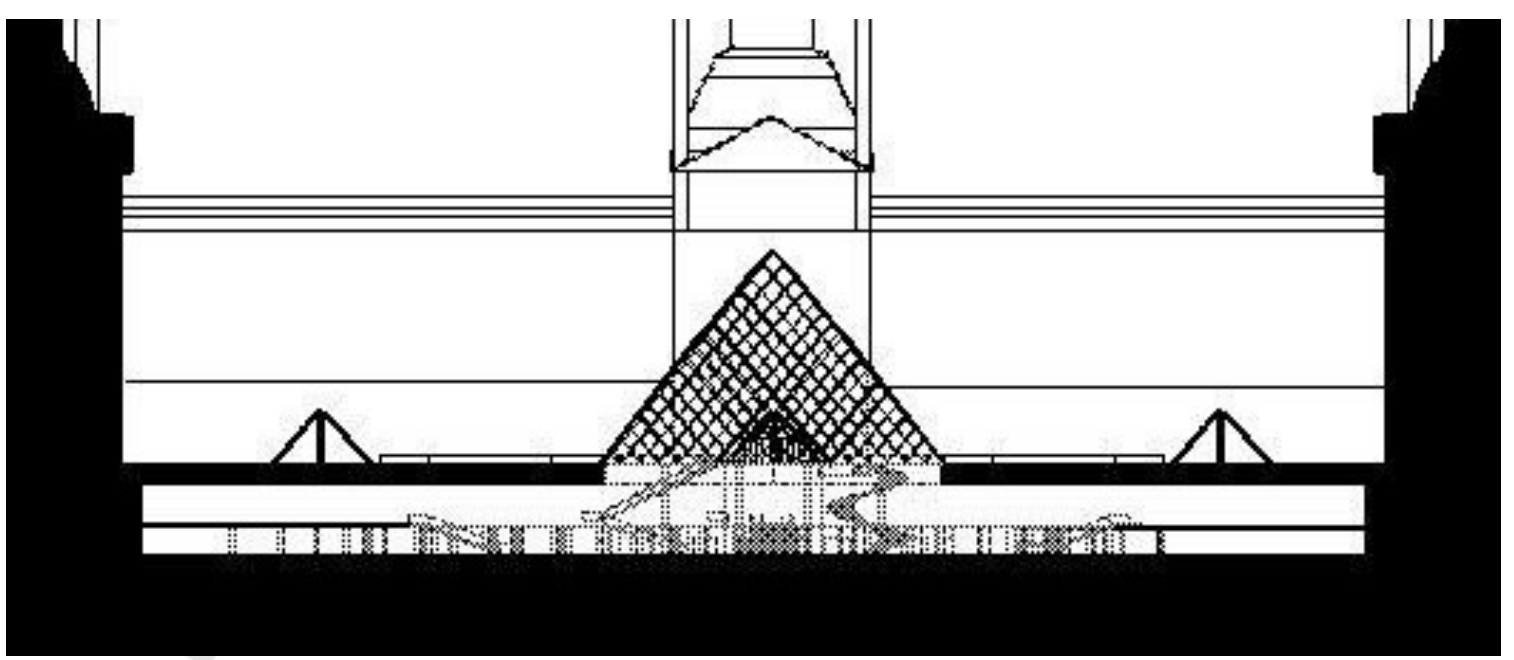

Nota: Corte de pirámide y acceso - Esquema

Fuente: Moleskin Arquitectónico, 2009. I'm Pei y el Museo del Louvre. Recuperado de https://goo.gl/ciJtn5

Figura 4.15

Corte longitudinal del proyecto

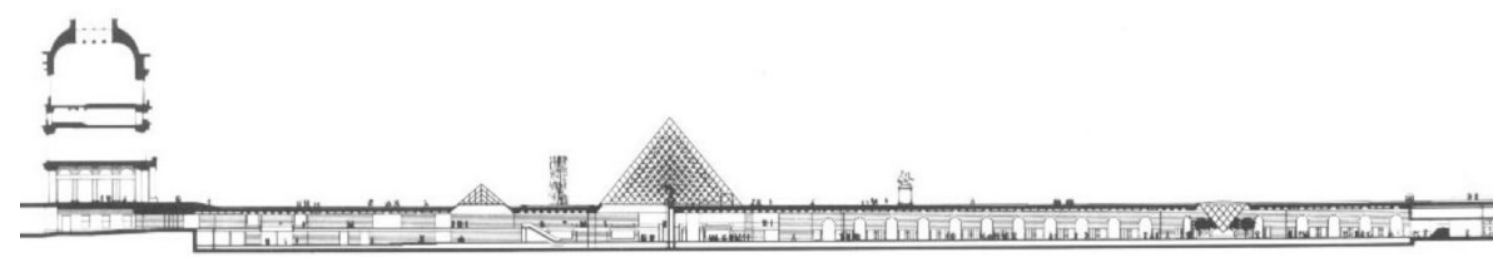

Nota: Corte de longitudinal esquemático del proyecto completo de amplación.

Fuente: Moleskin Arquitectónico, 2009. I'm Pei y el Museo del Louvre. Recuperado de https://goo.gl/ciJtn5 


\subsubsection{Museo Kolumba}

Ubicación: Colonia, Alemania

Arquitecto: Peter Zumthor

Año de intervención: 2003-2007

Ubicado en Colonia, una de las ciudades que se vio más afectadas tras la segunda guerra, este museo aloja antiguas e importantes colecciones de arte pertenecientes al arquidiócesis católica. (Archdaily, 2010. Peter Zumthor: Recuperación del Museo Kolumba)

En 1950, las ruinas de esta antigua iglesia románica fueron intervenidas por Gottfried Bohn y se empezó a utilizar como una capilla cuyo nombre sería Nuestra Señora de las Ruinas. En 1989 la arquidiócesis de Colonia tomó el control de la Sociedad de Arte Cristiano y decidió mudar las piezas en exhibición a un nuevo museo que sería inaugurado en el 2007.

El proyecto son conjunto de volúmenes ortogonales que se posan sobre el antiguo edificio. A pesar de que a nivel formal existen diferencias, la materialidad y porosidad de ciertas paredes del proyecto permiten que haya armonía entre ambos edificios. El programa de intervención y puesta en valor del Museo Kolumba incluye:

- Salas de exhibición

- Salas temporales o multiusos.

- Tiendas

- Depósitos y oficinas.

Tabla 4.3. Tipo de espacio y porcentaje

\begin{tabular}{|c|c|}
\hline Tipo de espacio & Porcentaje \\
\hline Público & 20 \\
\hline Semipúblico & 55 \\
\hline Privado & 25 \\
\hline
\end{tabular}

Nota: Tabla de tipos de espacio y porcentajes de espacios públicos, semipúblicos y privados.

Fuente: Elaboración propia, 2015

- Área libre: $40 \%$ de superficie original

- Área ocupada por proyecto: $60 \%$ de superficie original 


\section{Imágenes del proyecto}

Figura 4.16

Fachada exterior del Museo Kolumba

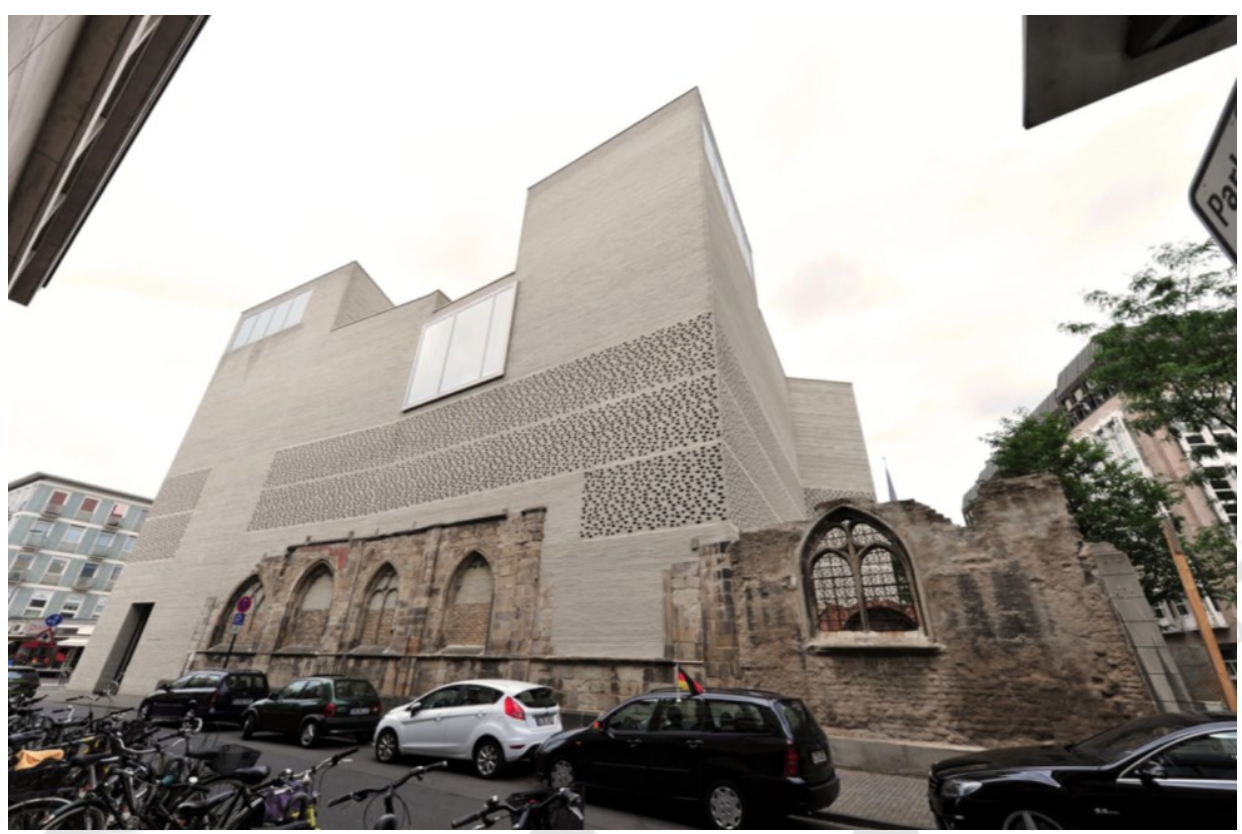

Nota: Vista exterior del Museo

Fuente: Archdaily, 2010. Peter Zumthor: Recuperación del Museo Kolumba. Recuperado de https://goo.gl/rgUZ9p

Figura 4.17

Vista interior desde el segundo piso del Museo Kolumba

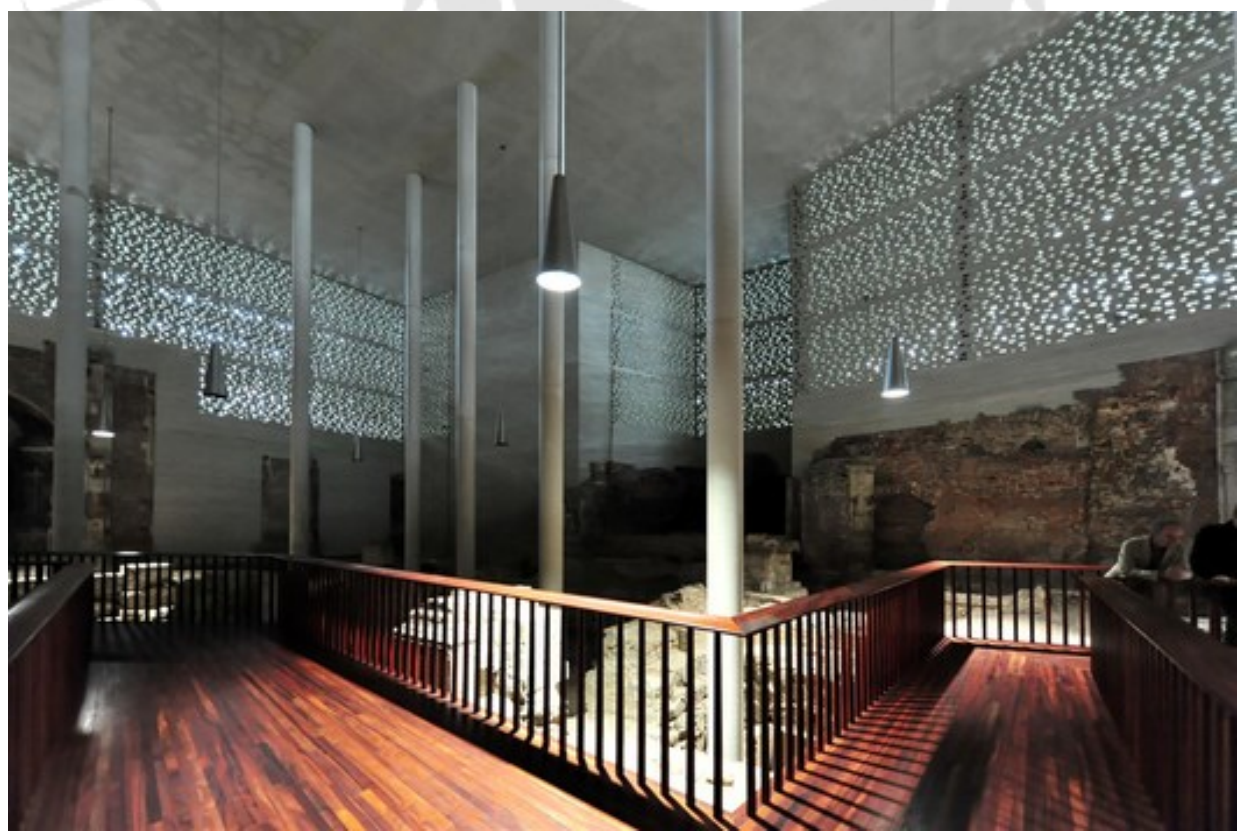

Nota: Vista interior desde el segundo piso

Fuente: Archdaily, 2010. Peter Zumthor: Recuperación del Museo Kolumba. Recuperado de https://goo.gl/rgUZ9p 


\section{Planos esquemáticos}

Figura 4.18. Primera planta del Museo Kolumba

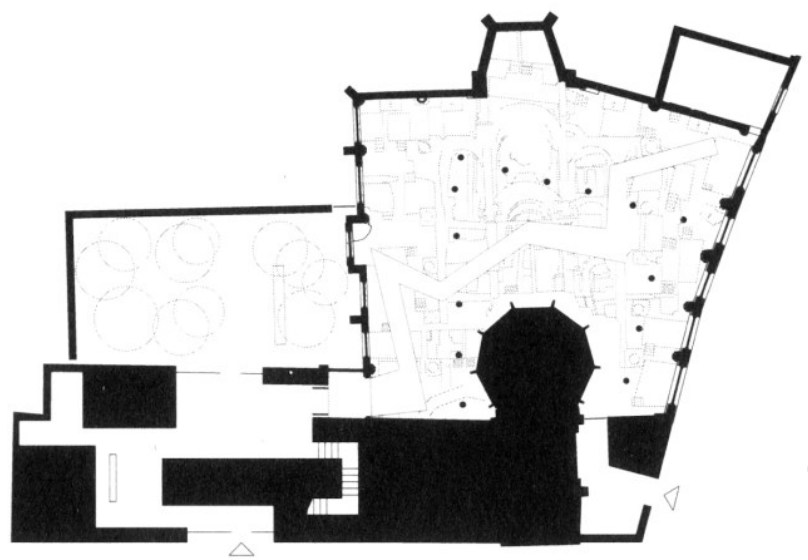

Fuente: Originals, 2015. Kolumba Museum Plan. Recuperado de https://goo.gl/6yc2Ea

Figura 4.19. Segunda planta del Museo Kolumba

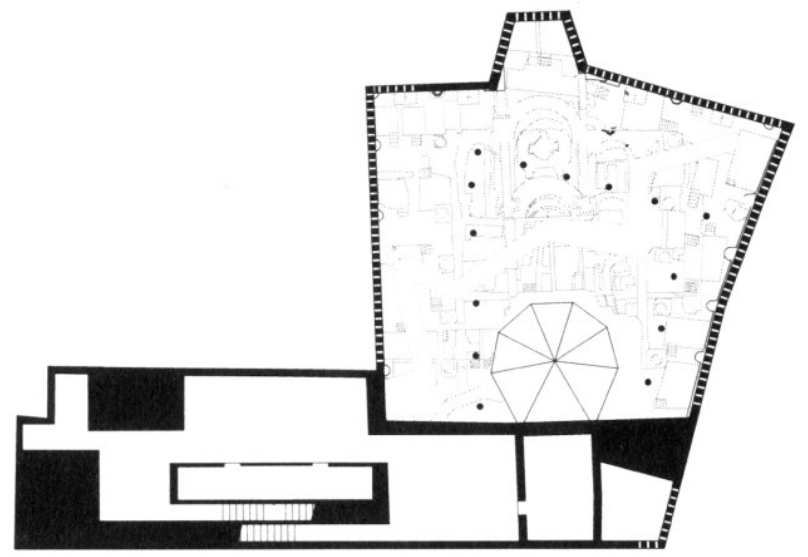

Fuente: Originals, 2015. Kolumba Museum Plan. Recuperado de https://goo.gl/6yc2Ea

Figura 4.20. Tercera planta del Museo Kolumba.

En celeste, las partes privadas.

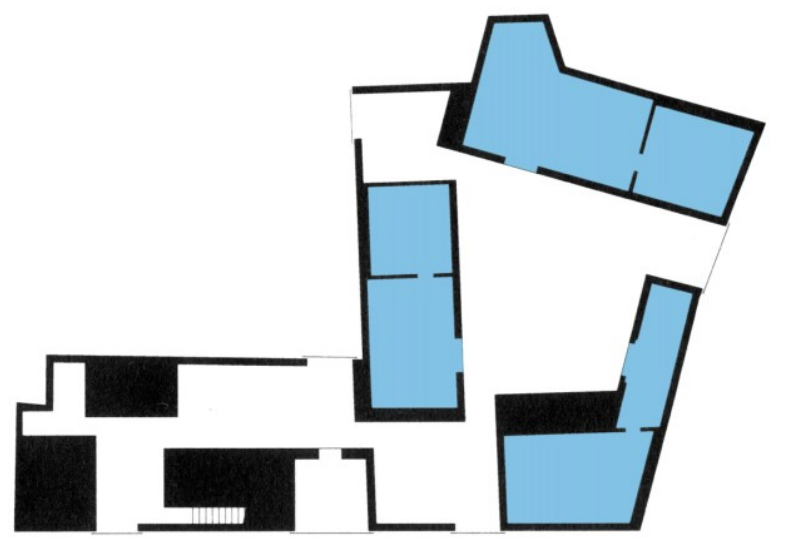

Fuente: Originals, 2015. Kolumba Museum Plan. Recuperado de https://goo.gl/6yc2Ea 


\subsubsection{Centro Cultural de La Moneda}

Ubicación: Santiago de Chile, Chile

Arquitecto: Undurraga Devés Arquitectos

Año de intervención: 2005

El proyecto, diseñado por Undurraga Devés, busca articular espacios públicos solemnes del casco administrativo de la ciudad a otro sistema macro de ejes propuesto como intervención mayor. Se propone reunir actividades que actualmente están dispersas, acoger y reunir diversos actos ciudadanos. (Archdaily, 2006)

La Plaza de la Ciudadania nace en el 2005 como una de las etapas para conmemorar el bicentenario de la independencia de Chile, sobre un antiguo terreno que servía de estacionamiento de autos al lado dell Palacio de la Moneda, sede del poder ejecutivo. Formalmente, es una plaza hundida cubierta a la cual se accede a través rampas laterales. Además, para atenuar el efecto sólido del concreto, la composición general cuenta con piletas a ambos lados a nivel de superficie y caídas de agua en las entradas laterales.

El programa de intervención y proyecto de Centro Cultural de la Moneda incluye:

- Salas de exhibición

- Salas temporales o multiusos.

- Tiendas

- Depósitos y oficinas.

Tabla 4.4. Tipo de espacio y porcentaje

\begin{tabular}{|c|c|}
\hline Tipo de espacio & Porcentaje \\
\hline Público $/ /$ & 50 \\
\hline Semipúblico & 25 \\
\hline Privado & 25 \\
\hline
\end{tabular}

Nota: Tabla de tipos de espacio y porcentajes de espacios públicos, semipúblicos y privados.

Fuente: Elaboración propia, 2015

- Área libre: $100 \%$ en superficie

- Área ocupada por proyecto: $100 \%$ subterránea 
Figura 4.21

Vista exterior del Centro Cultural de la Moneda

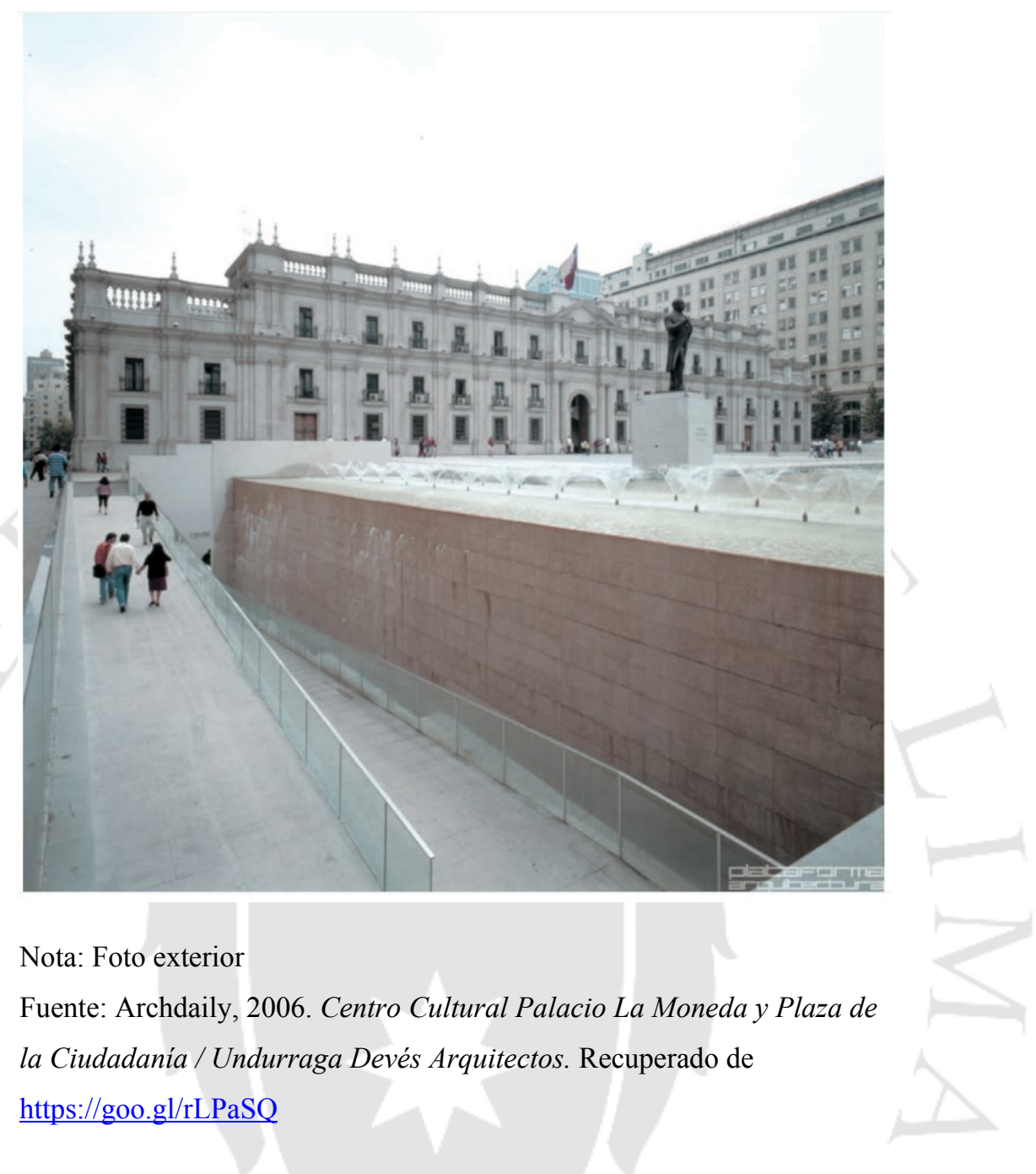

Figura 4.22

Corte A-A' del Centro Cultural de la Moneda

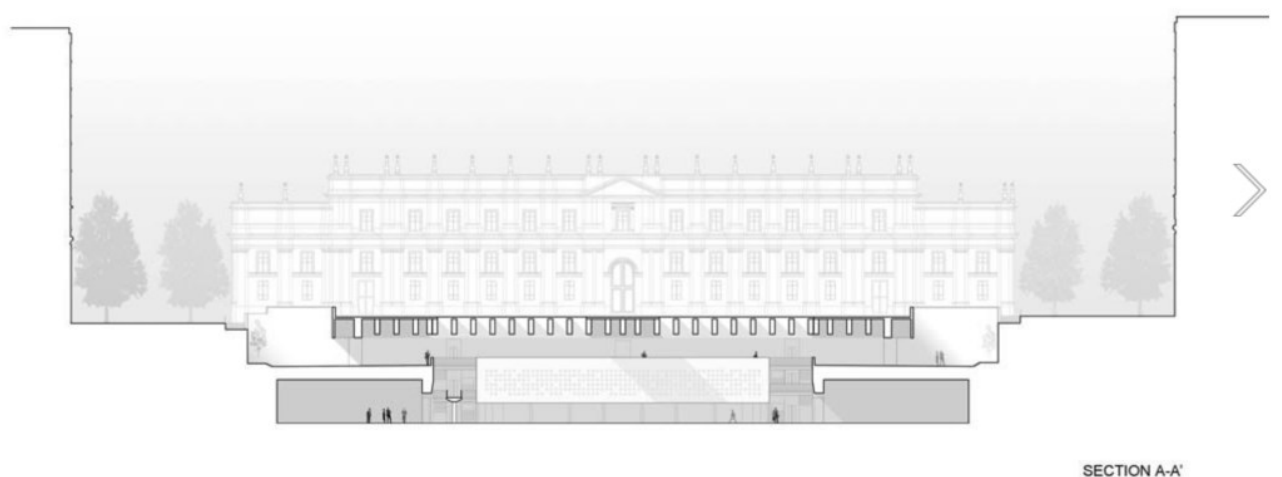

Nota: Corte esquemático

Fuente: Archdaily, 2006. Centro Cultural Palacio La Moneda y Plaza de la Ciudadanía I

Undurraga Devés Arquitectos. Recuperado de https://goo.gl/rLPaSQ 
Figura 4.23

Ingreso - Hall central

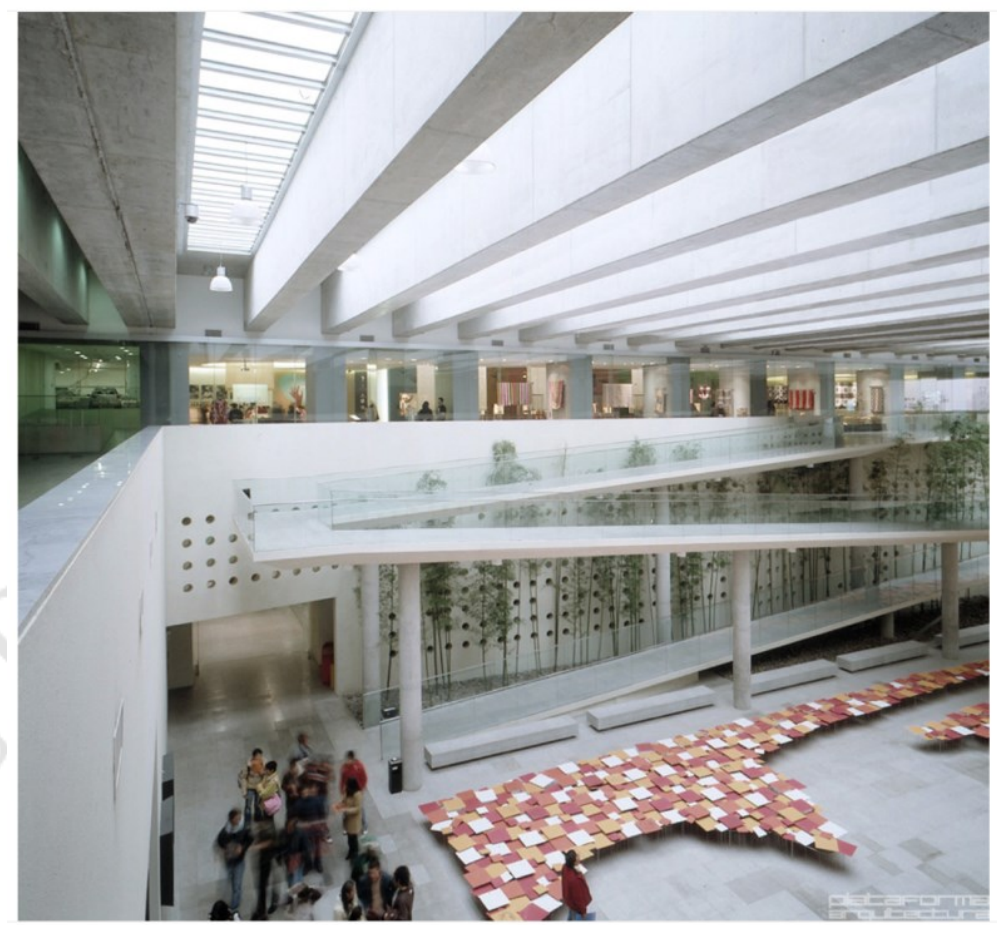

Nota: Foto de vista interior y hall de ingreso

Fuente: Archdaily, 2006. Centro Cultural Palacio La Moneda y Plaza

de la Ciudadanía / Undurraga Devés Arquitectos. Recuperado de

https://goo.gl/rLPaSQ

El proyecto se encuentra al sur de la fachada principal del Palacio de la Moneda, debajo del Patio de Honor.

Figura 4.24. Planta de nivel $+/-0.00 \mathrm{~m}$

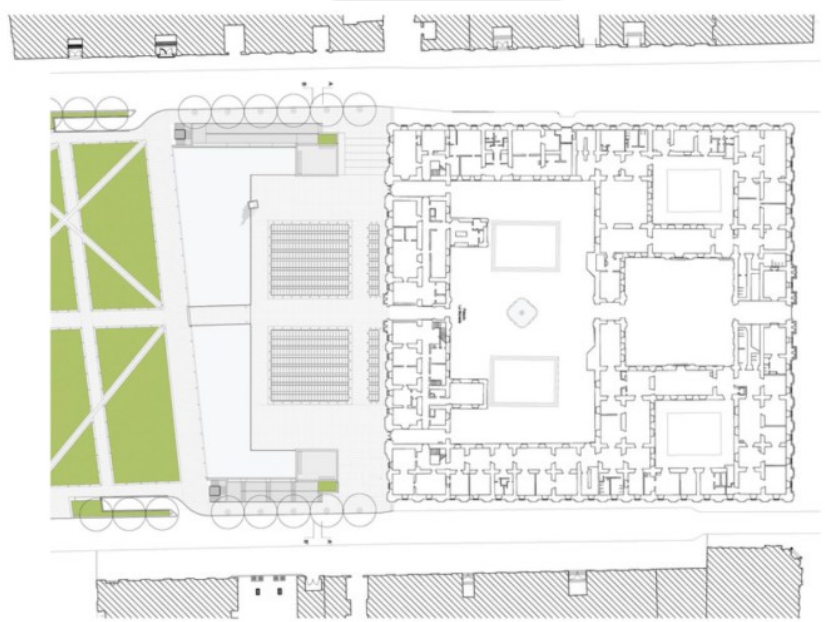

Nota: Planta esquemática de nivel calle con plaza y Palacio de la Moneda

Fuente: Archdaily, 2006. Centro Cultural Palacio La Moneda y Plaza de la Ciudadanía

/Undurraga Devés Arquitectos. Recuperado de https://goo.gl/rLPaSQ 
Figura 4.25. Sótano 1 esquemático del Centro Cultural de la Moneda

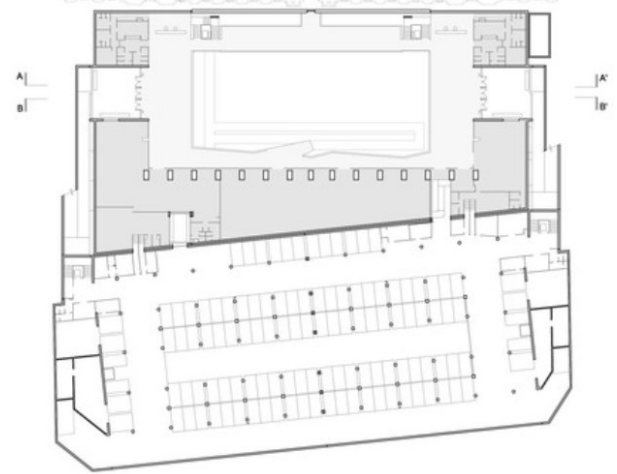

Fuente: Archdaily, 2006. Centro Cultural Palacio La Moneda y Plaza de la Ciudadanía / Undurraga Devés Arquitectos. Recuperado de https://goo.gl/rLPaSQ

Figura 4.26. Sótano 2 esquemático del Centro Cultural de la Moneda

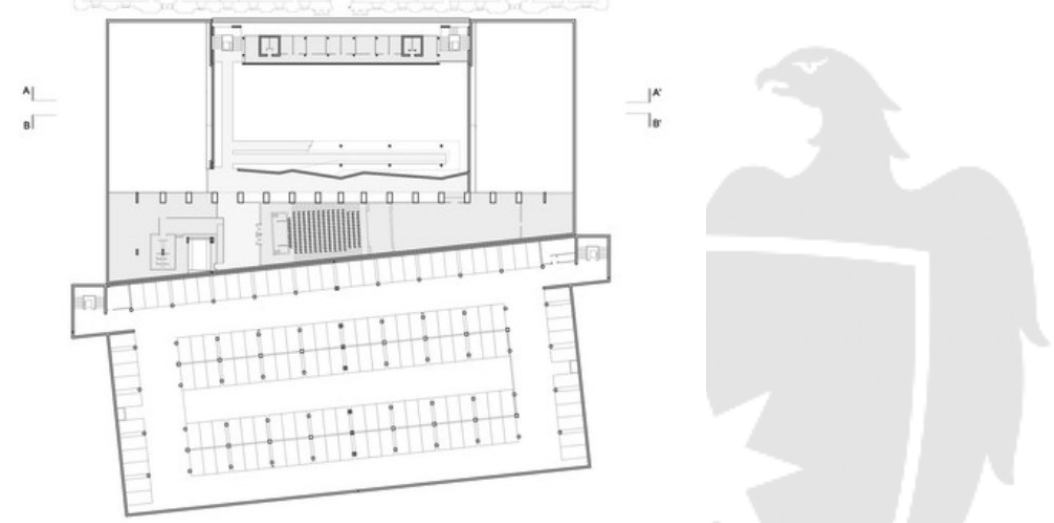

Fuente: Archdaily, 2006. Centro Cultural Palacio La Moneda y Plaza de la Ciudadanía / Undurraga Devés Arquitectos. Recuperado de https://goo.gl/rLPaSQ

Figura 4.27. Sótano 3 esquemático del Centro Cultural de la Moneda

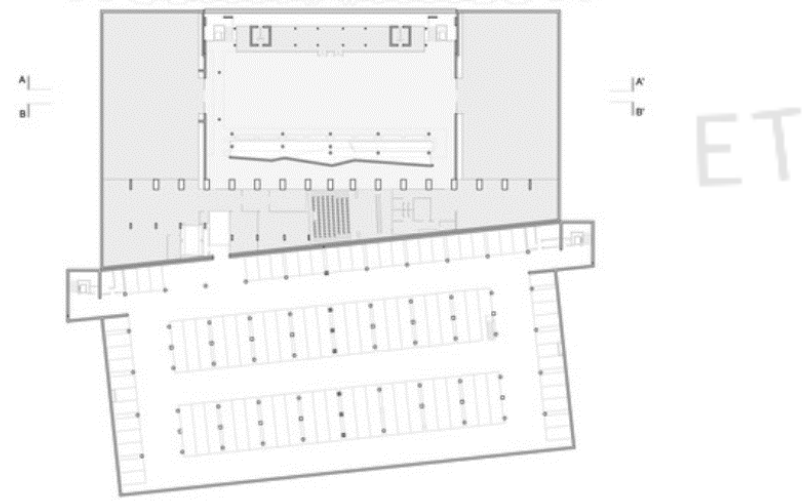

Fuente: Archdaily, 2006. Centro Cultural Palacio La Moneda y Plaza de la Ciudadanía / Undurraga Devés Arquitectos. Recuperado de https://goo.gl/rLPaSQ 


\subsection{Análisis comparativo de proyectos}

Se han definido 8 variables comparativas:

\subsubsection{Función}

La función primordial de todo museo es exhibir las piezas de museografía que alberga, además de servir de centro cultural y de sala(s) de exhibición temporal(es). En los tres primeros ejemplos, el Museo Judío de Berlín, el Louvre (pirámide de Pei) y el Museo de Kolumba, estas funciones se cumplen en distinta medida de acuerdo al espacio y la particularidad de la muestra presente en cada de estos edificios: en el primero se muestra una especie de "viaje de descubrimiento de la historia Judío-Alemana por 2000 años.", en el segundo, son exhibiciones históricas de "arte global" y en el tercero es una colección de arte "antiguo religioso y contemporáneo" europeo. Todos presentan circulaciones lineales, aunque pueden ser recorridos de manera libre también. En el Centro Cultural de la Moneda, sus salas temporales se encargan de difundir la identidad y la cultural de Chile.

El aforo varía de acuerdo a la espacialidad de cada edificio.

\subsubsection{Contexto}

Todos los proyectos referenciales están localizados en contextos históricos antiguos de valor patrimonial, sin embargo, estos predios monumentales se encuentran o encontraban en distintas condiciones.

Figura 4.28

Emplazamiento del Museo Judío de Berlín

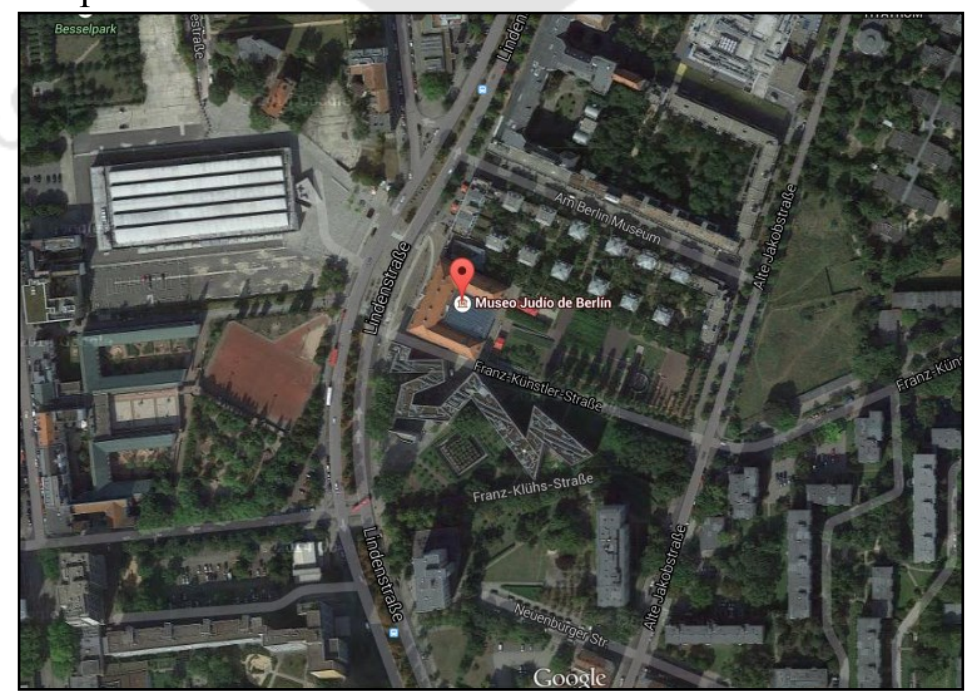

Fuente: Google Maps, 2015. Emplazamiento del Museo Judio de Berlín. Recuperado de https://goo.gl/vO4Db3 
En el caso de del Museo Judío, la intervención de Libenskind se anexa al edificio antiguo y es completamente honesto respecto a su naturaleza contemporánea. De hecho, logra cierta armonía y se convierte en una especie de escultura en el paisaje del área. Este complejo cultural se localiza en un suburbio semiurbano.

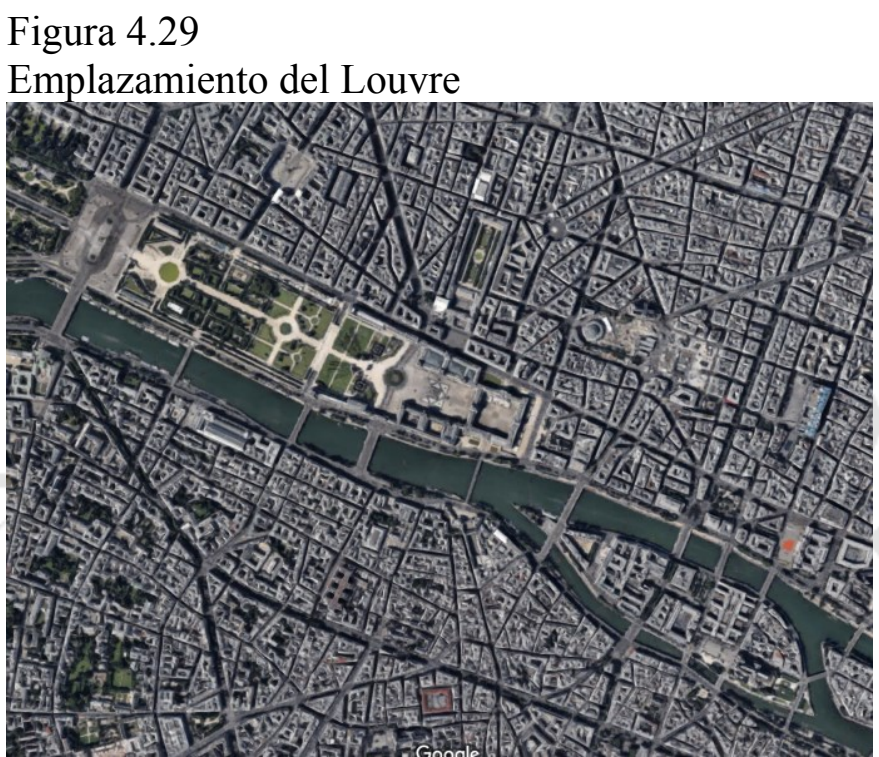

Fuente: Google Maps, 2015. Emplazamiento del Museo Louvre. Recuperado de https://goo.gl/dfVAK2

De la misma manera, el Museo del Louvre y la intervención piramidal de Pei a manera de Hall de reunión e ingreso son otro ejemplo de la adecuación al uso de un espacio que antes era simplemente una explanada vacía que servía de cubierta para los pasajes subterráneos del otrora palacio. En este ejemplo también existe una armonía por contraste (la cual fue muy polémica en un inicio), y además el material utilizado no puede ser más transparente respecto a su origen: vidrio.

Figura 4.30

Emplazamiento del Museo de Kolumba

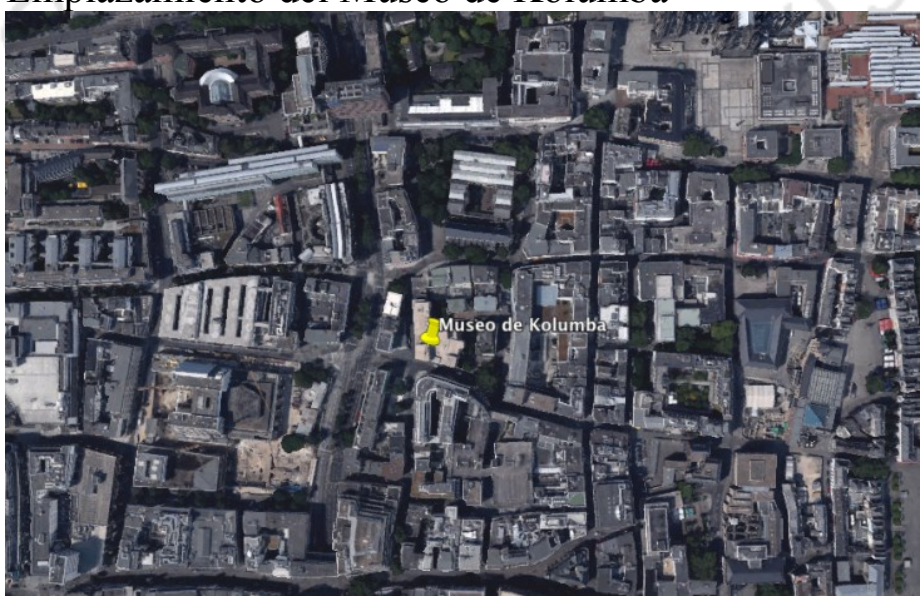

Fuente: Google Maps, 2015. Emplazamiento del Museo Kolumba. Recuperado de https://goo.gl/V4rCaI 
En el caso particular del Museo de Kolumba, el contexto inmediato eran las ruinas de una antigua iglesia destruida por bombardeos, lo que llevo a los encargados del proyecto a recuperar lo que era posible del edificio antes de cualquier intervención. Asimismo, Zumthor, a la hora de intervenir el edificio y generar este nuevo volumen que se posa sobre el antiguo edificio, tuvo en cuenta la materialidad original del predio y propuso el uso de colores y texturas que que armonizaran con el entorno. El uso del ladrillo y la porosidad de la nueva ampliación respetan la monumentalidad del lugar.

Figura 4.31

Emplazamiento del Centro Cultural del Palacio de la Moneda

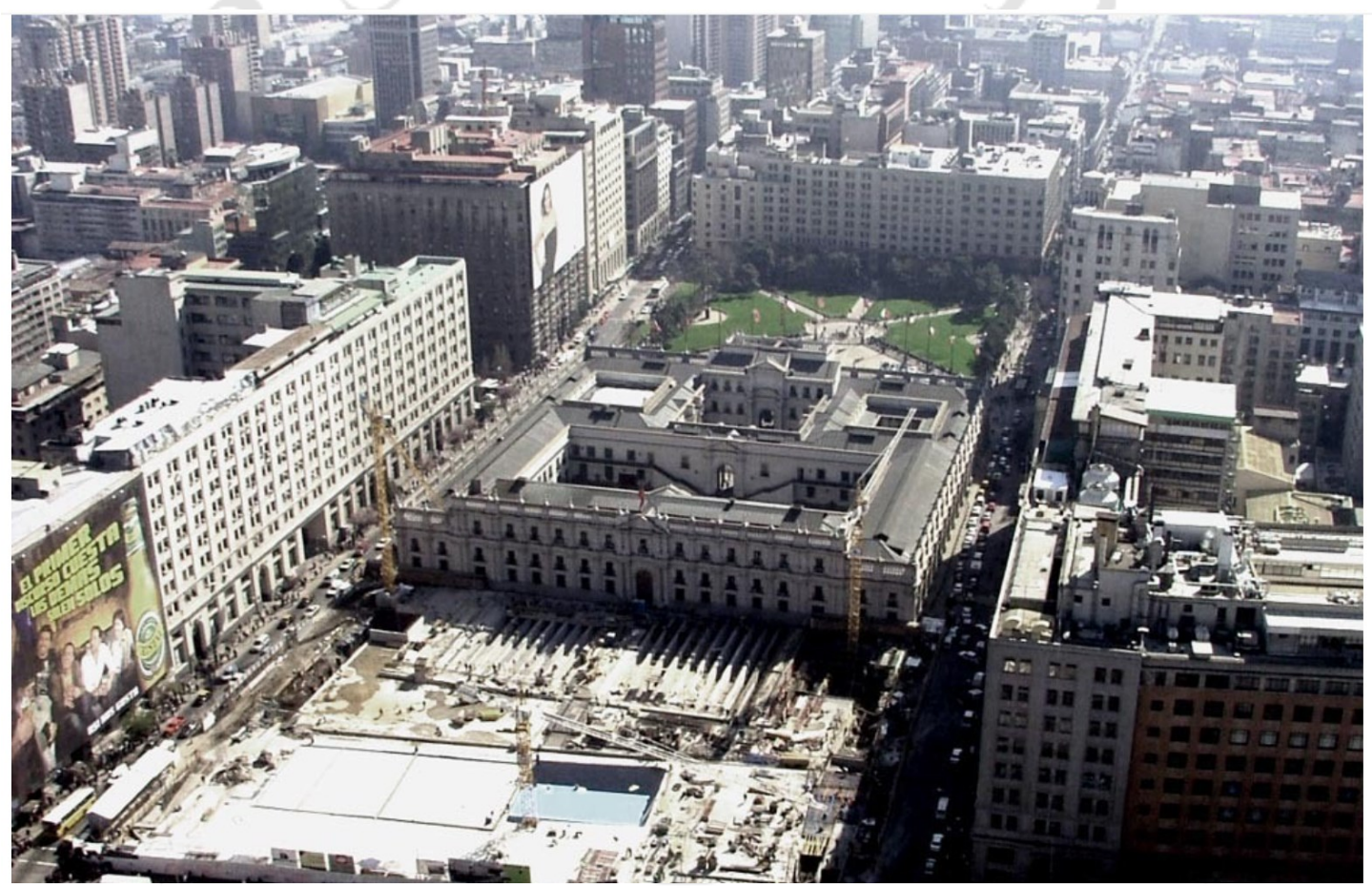

Nota: Emplazamiento del Centro Cultural de la Moneda durante su construcción

Fuente: Archdaily, 2006. Centro Cultural Palacio La Moneda y Plaza de la Ciudadanía / Undurraga

Devés Arquitectos. Recuperado de https://goo.gl/rLPaSQ

El Centro Cultural de la Moneda se encuentra el Centro Histórico de Santiago de Chile, cuyo contexto inmediato data de principios del siglo XX, ya que fue remodelado por el centenario de la independencia chilena. Los edificios que circundan la plaza son de carácter modernista, con detalles neoclásicos.

\subsubsection{Forma}

En todos los proyectos, la intervención a nivel formal varía bastante, ya que se adapta al contexto y a la función que cada muestra en particular debe cumplir. Sin embargo, se 
puede afirmar que el desplazamiento dentro de estos volúmenes es libre y cruzado (horizontal y verticalmente) en los tres últimos casos mostrados. En el caso particular del Museo de Berlín, la circulación es únicamente lineal y en un sentido, ya que todo el edificio pretende generar sensaciones a manera que se vaya avanzando dentro de la muestra, como se si estuviese escuchando una historia.

En la siguiente gráfica se muestra el flujo de personas por el recorrido museográfico de los museos analizados.

Figura 4.32

Comparación de área de influencia y recorridos

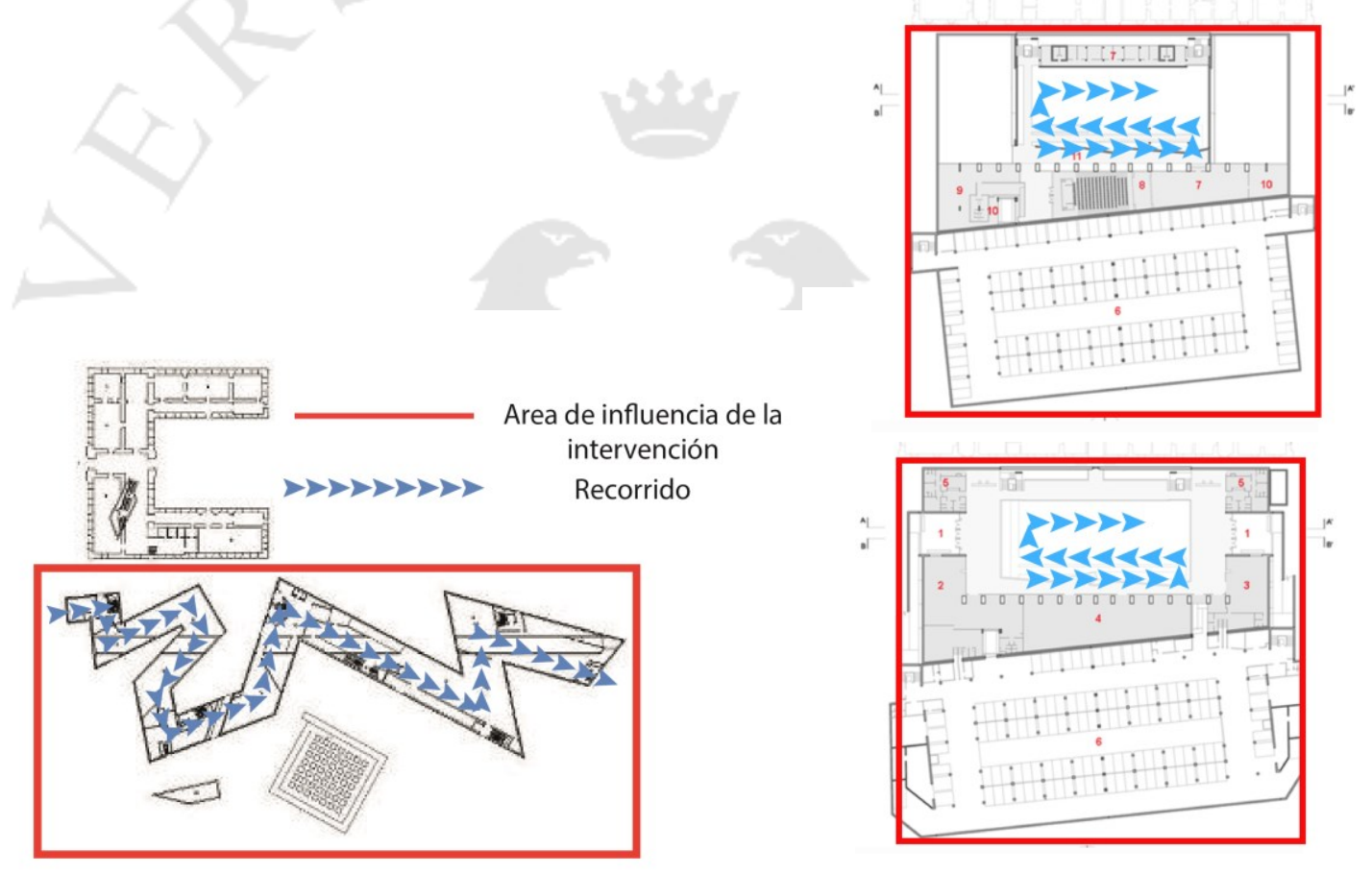

Museo Judío de Berlín

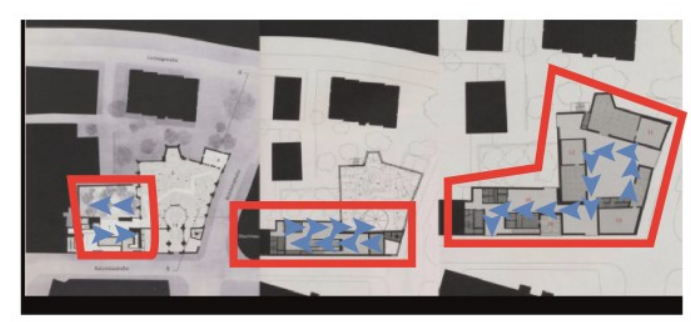

Museo Kolumba
Centro Cultural de la Moneda

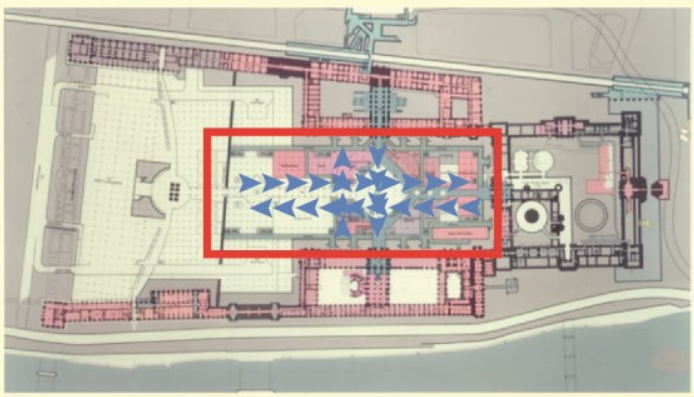

Museo Louvre

Nota: Comparación de distintas áreas de influencia y recorrrido de los 4 casos análogos presentados.

Fuente: Elaboración propia, 2016 


\subsubsection{Materialidad}

El Museo del Louvre tiene intervenciones de vidrio con estructura metálica. La transparencia del material evita que el edificio de interés monumental sea tapado, pero a su vez logra crear una ilusión visual de contención ortogonal (ej. La pirámide, los rectángulos).

En el caso del Museo Judío de Berlín, el edificio nuevo está hecho completamente de concreto armado y con recubrimiento de sistema de aluminio compuesto. Este edificio no busca ocultarse, sino destacar y contrastar.

El Museo de Kolumba es muy particular en términos de materialidad, ya a diferencia de los ejemplos anteriores, los materiales de ambos edificios (el antiguo y el nuevo) se tocan en un punto; sin embargo, y a pesar de este contraste visual, el arquitecto trato de imitar de alguna manera con el color y la textura las paredes originales. De esta manera logra no distanciarse tanto del monumento, y crea así una tensión cromática entre este y el volumen que interviene.

En el caso de Centro Cultural de la Moneda, la materialidad es concreto armado expuesto y detalles de seguridad (barandas, parapetos) en vidrio. Además, la iluminación del espacio se da por entradas cenitales vidriadas en el techo.

\subsubsection{Usuario}

En lo que respecta al Museo del Louvre y el Museo de Kolumba, ambos están dirigidos a un público en busca de arte, histórico y contemporáneo, de importancia e impacto global. El usuario es puede ser una persona adulta como niños, y también personas con discapacidades físicas ya que ambos predios han sido preparados para recibirlos.

Para el Museo Judío de Berlín, el usuario es una persona ávida de entender y compenetrarse con la cultura judía y su presencia en Europa. La intervención de Libenskind es un juego de visuales y sensaciones y emociones, por lo que está más orientada a adultos cultivados más que a niños.

El Centro Cultural de la Moneda tiene como principal usuario a los turistas, nacionales e internacionales, que vienen a visitar Santiago de Chile. Este edificio también es visitado por estudiantes y personas interesadas en la historia de la ciudad. 


\subsubsection{Comparación de Programas}

Las diferencias importantes entre los programas están en las tablas comparativas al finalizar esta sección. A continuación, se muestran los programas de los cuatro proyectos.

Diagrama 4.1

Comparación de programas
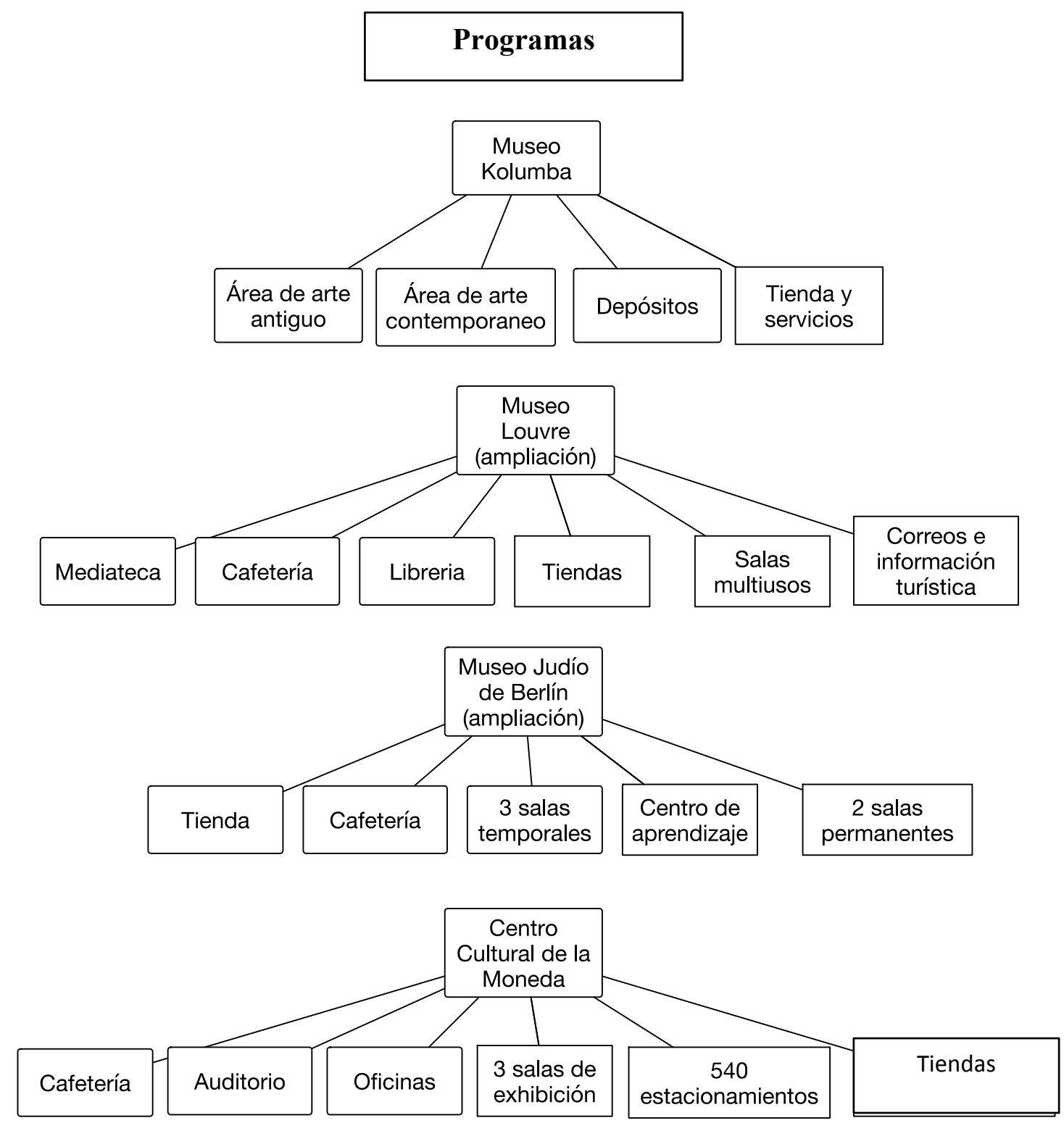

Nota: Comparación de los programas de los 4 proyectos análogos estudiados.

Fuente: Elaboración propia, 2016 


\subsubsection{Usos públicos y privados}

Museo Judío de Berlín:

Área libre : $65 \%$

Área ocupada: $35 \%$

Relación entre espacios: El ingreso es a través del espacio semi-púplico como control (el edificio antiguo). Luego, el usuario se conecta a una plaza central para luego volver a entrar un espacio semipúblico recientemente construido (el edificio nuevo). Finalmente, el recorrido termina en un espacio público al aire libre.

Las áreas privadas y administrativas están en el edificio antiguo, por lo que no aparecen en las figuras mostradas.

\section{Figura 4.33}

Esquema de áreas públicas y semipúblicas del Museo Judío de Berlín
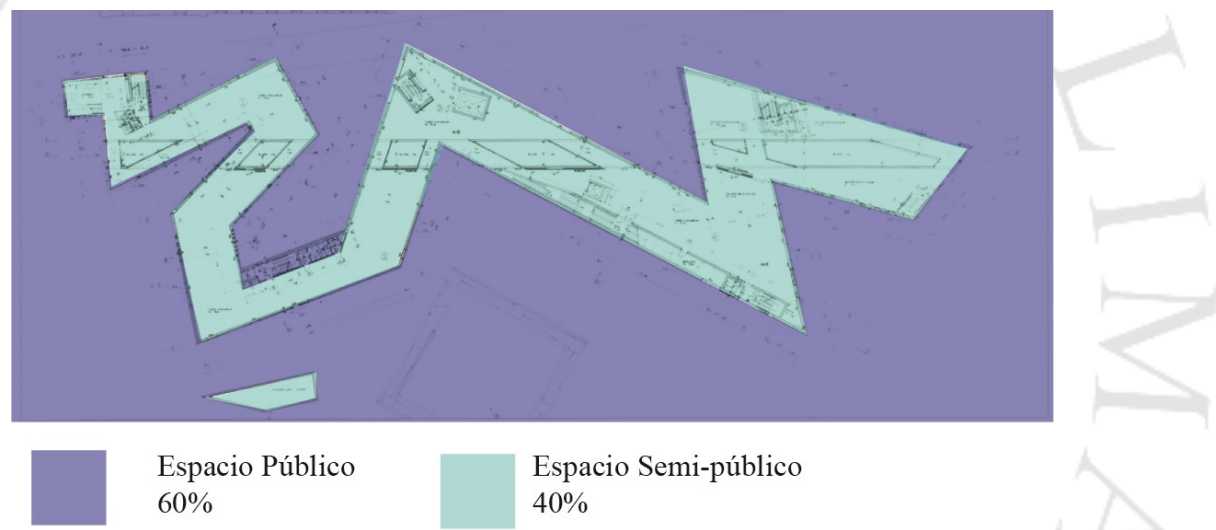

Espacio Semi-público $40 \%$

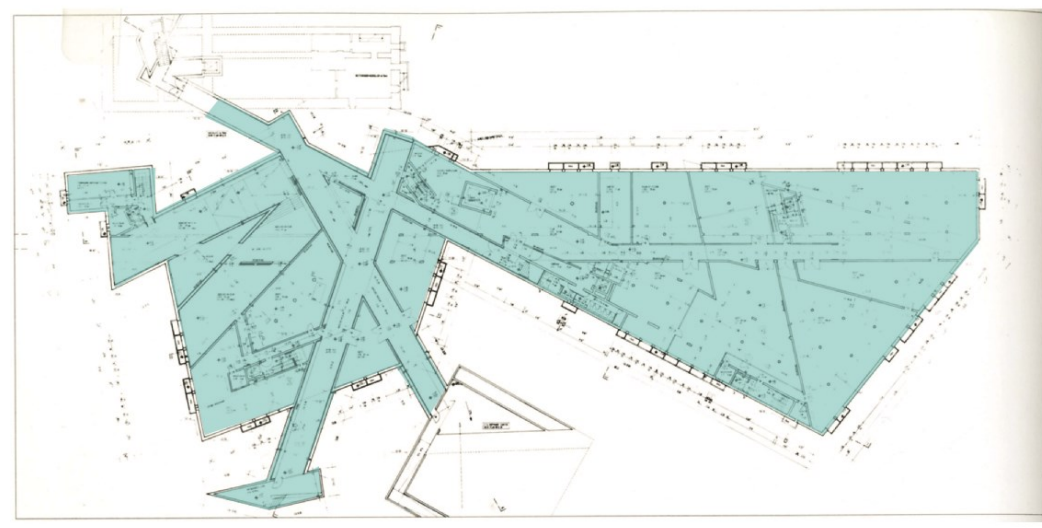

Espacio Semi-público $100 \%$

Nota: Plantas del Museo Judío de Berlín donde se evidencia el porcentaje de tipo de espacio. Fuente: Adaptado de Archi DIAP, 2014. Museo Judío de Berlín. Recuperado de https://goo.gl/3BT2X4 
Museo del Louvre (ampliación de Pei):

Área libre: $70 \%$

Área ocupada por proyecto: $30 \%$

Relación entre espacios: El edificio original encierra un gran patio central público. Toda la primera planta es semipública con control de accesos, al igual que la intervención subterránea. El recorrido es libre, aunque existe una circulación lineal sugerida. Existe una sección privada administrativa en la segunda planta del edificio antiguo.

Figura 4.34

Esquema de planta de nivel 1 - Museo del Louvre

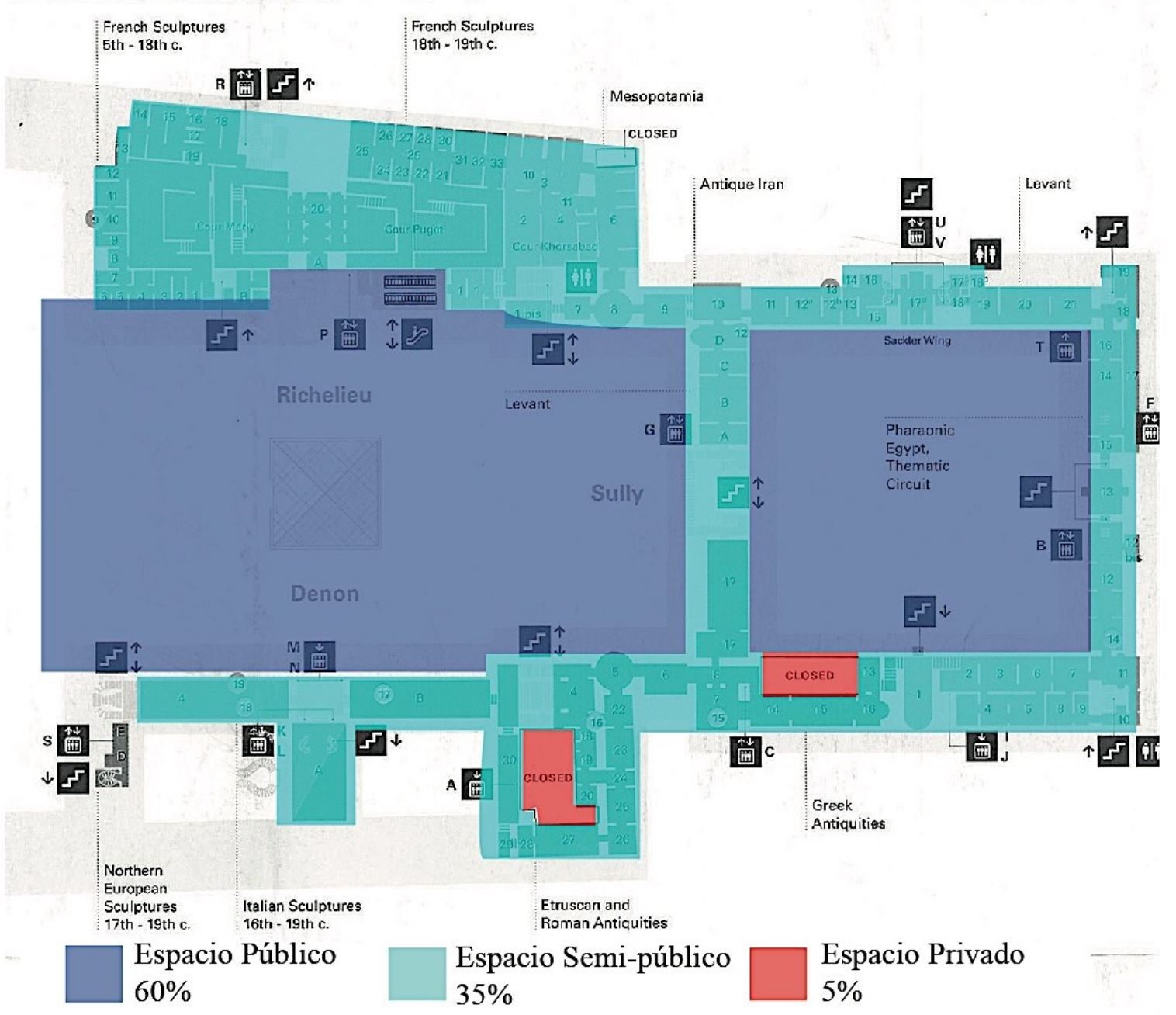

Nota: Plantas del Louvre donde se evidencia el porcentaje de tipo de espacio.

Fuente: Adaptado de Moleskin Arquitectónico, 2009. I'm Pei y el Museo del Louvre. Recuperado de https://goo.gl/ciJtn5 
Figura 4.35

Esquema de sótano 1 - Museo del Louvre

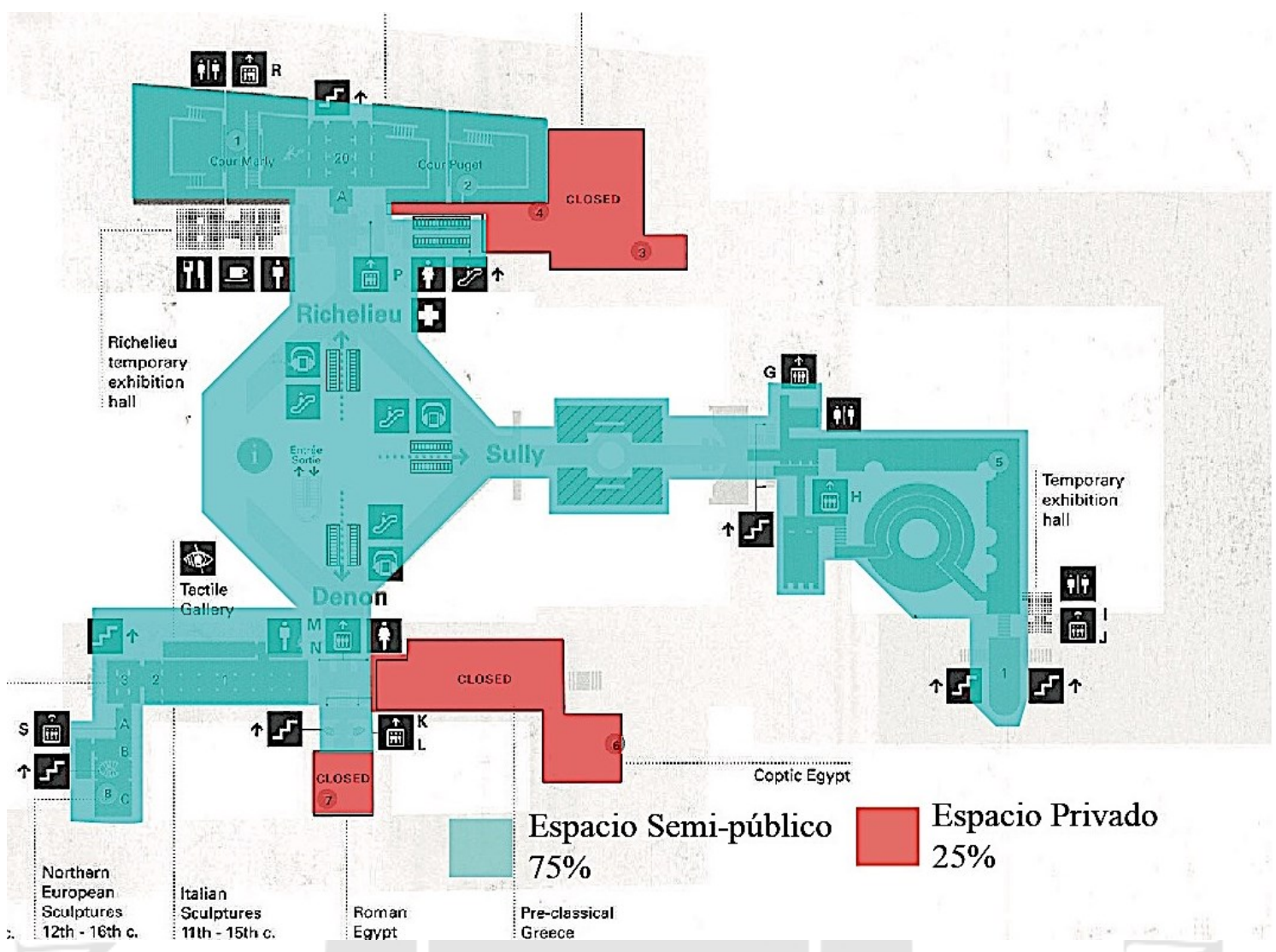

Nota: Plantas del Louvre donde se evidencia el porcentaje de tipo de espacio.

Fuente: Adaptado de Moleskin Arquitectónico, 2009. I'm Pei y el Museo del Louvre. Recuperado de https://goo.gl/ciJtn5

Museo de Kolumba:

Área libre: 60\%

Área ocupada por proyecto: $40 \%$

Relación entre espacios: Las tres plantas del edificio están abiertas al público y la circulación es lineal dentro de un circuito establecido. La principal función de los ambientes es expositiva y contemplativa. 
Figura 4.36

Plantas esquemáticas del museo de Kolumba

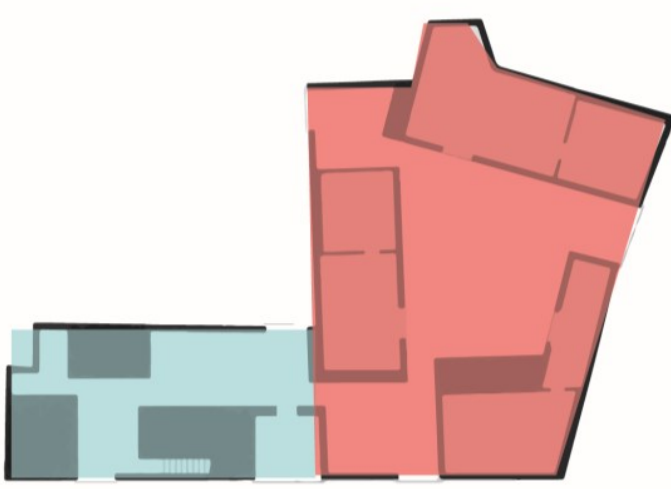

Tercer piso

Espacio semi-público

$40 \%$

Espacio privado

$60 \%$

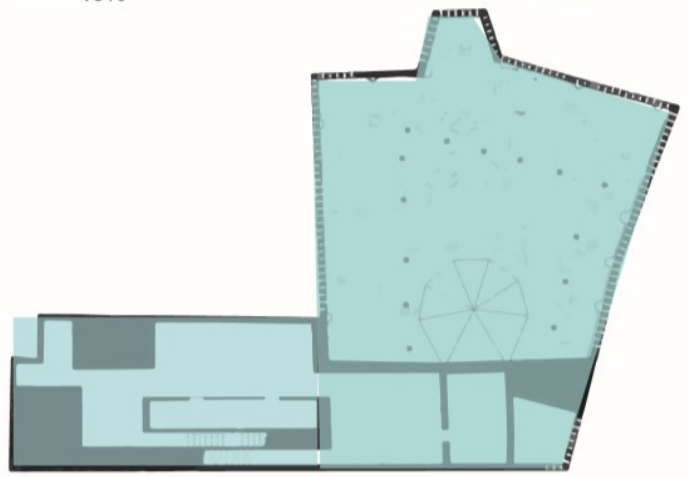

Segundo piso

Espacio semi-público $100 \%$

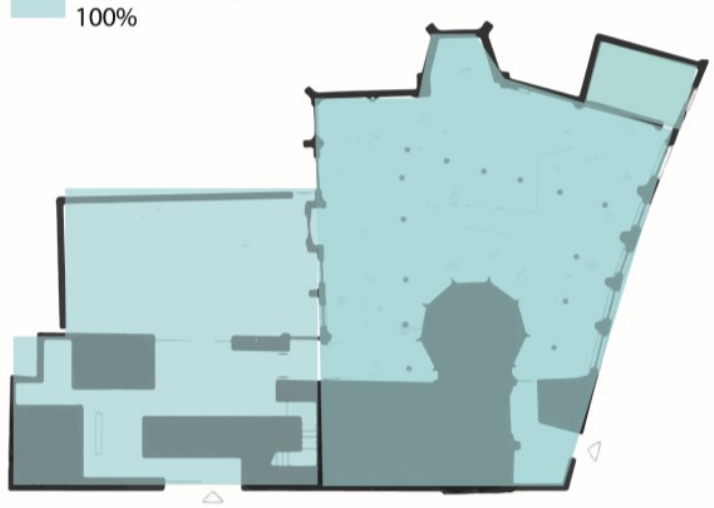

Primer piso

Espacio semi-público

$100 \%$

Nota: Plantas del Museo Kolumba donde se evidencia el porcentaje de tipo de espacio.

Fuente: Adaptado de Originals, 2015. Kolumba Museum Plan. Recuperado de https://goo.gl/6yc2Ea 
Centro Cultural de la Moneda:

Área libre en superficie: $100 \%$

Área ocupada subterránea: $100 \%$

Relación entre espacios: el espacio público central articula los demás espacios y sirve de ingreso y salida para los visitantes. Este espacio esta circundado por rampas de ingreso y tiendas alrededor que acompañando el descenso del usuario hacia los otros espacios interiores.

Figura 4.37

Esquemas primer sótano de Centro Cultural de la Moneda

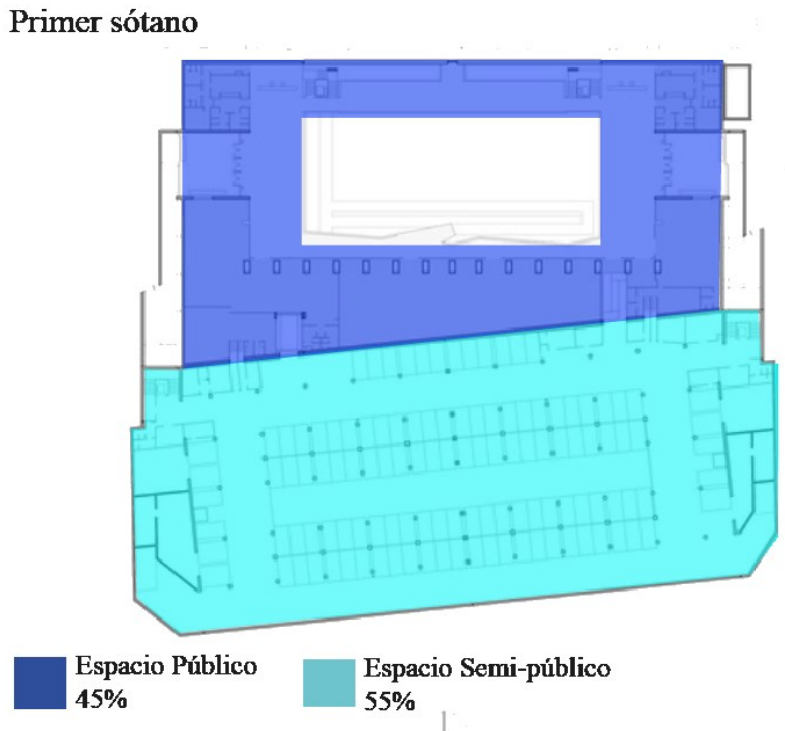

Nota: Sótano 1 del Centro Cultural de la Moneda donde se evidencia el porcentaje de tipo de espacio. Fuente: Adaptado de Archdaily, 2006. Centro Cultural Palacio La Moneda y Plaza de la Ciudadanía / Undurraga Devés Arquitectos. Recuperado de https://goo.gl/rLPaSQ 


\section{Figura 4.38}

Esquema de segundo sótano del Centro Cultural de la Moneda

\section{Segundo sótano}

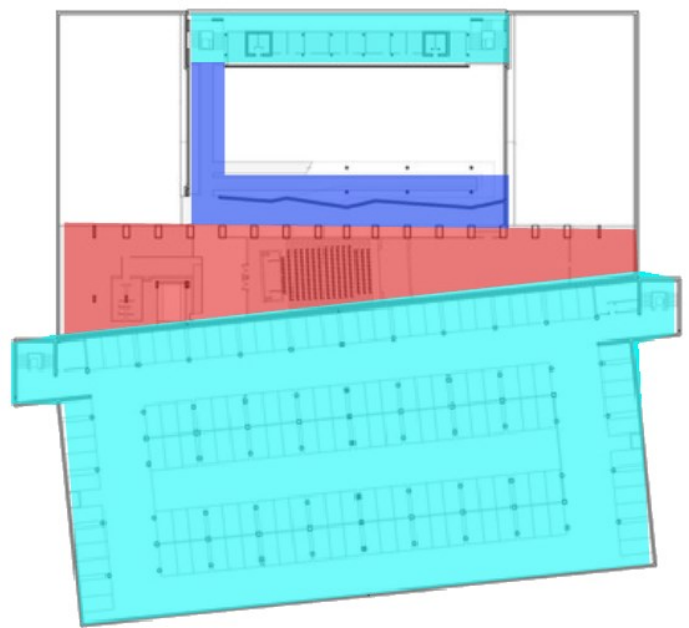

Espacio Público

$15 \%$

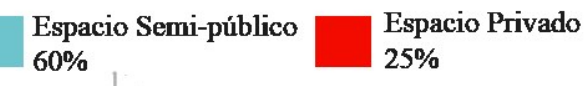

Nota: Sótano 2 del Centro Cultural de la Moneda donde se evidencia el porcentaje de tipo de espacio.

Fuente: Adaptado de Archdaily, 2006. Centro Cultural Palacio La Moneda y Plaza de la Ciudadanía / Undurraga Devés Arquitectos. Recuperado de https://goo.gl/rLPaSQ

\section{Figura 4.39}

Esquema de tercer sótano del Centro Cultural de la Moneda

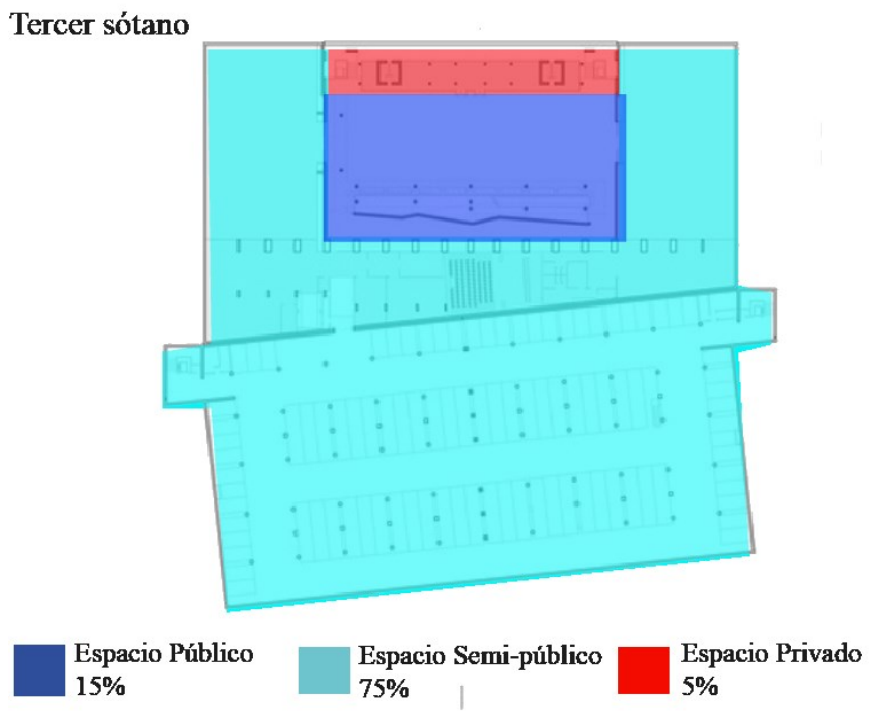

Nota: Sótano 3 del Centro Cultural de la Moneda donde se evidencia el porcentaje de tipo de espacio. Fuente: Adaptado de Archdaily, 2006. Centro Cultural Palacio La Moneda y Plaza de la Ciudadanía / Undurraga Devés Arquitectos. Recuperado de https://goo.gl/rLPaSQ 


\subsubsection{Tecnología}

Los museos mencionados, son en su mayoría, obra nueva, y usan métodos constructivos convencionales modernos. Sin embargo, el Museo de Kolumba tiene como característica que está construido sobre el edificio antiguo preexistente, por lo evidencia un trabajo muy delicado de intervención y un uso de tecnología constructiva particular.

Figura 4.40

Fachada del Museo de Kolumna

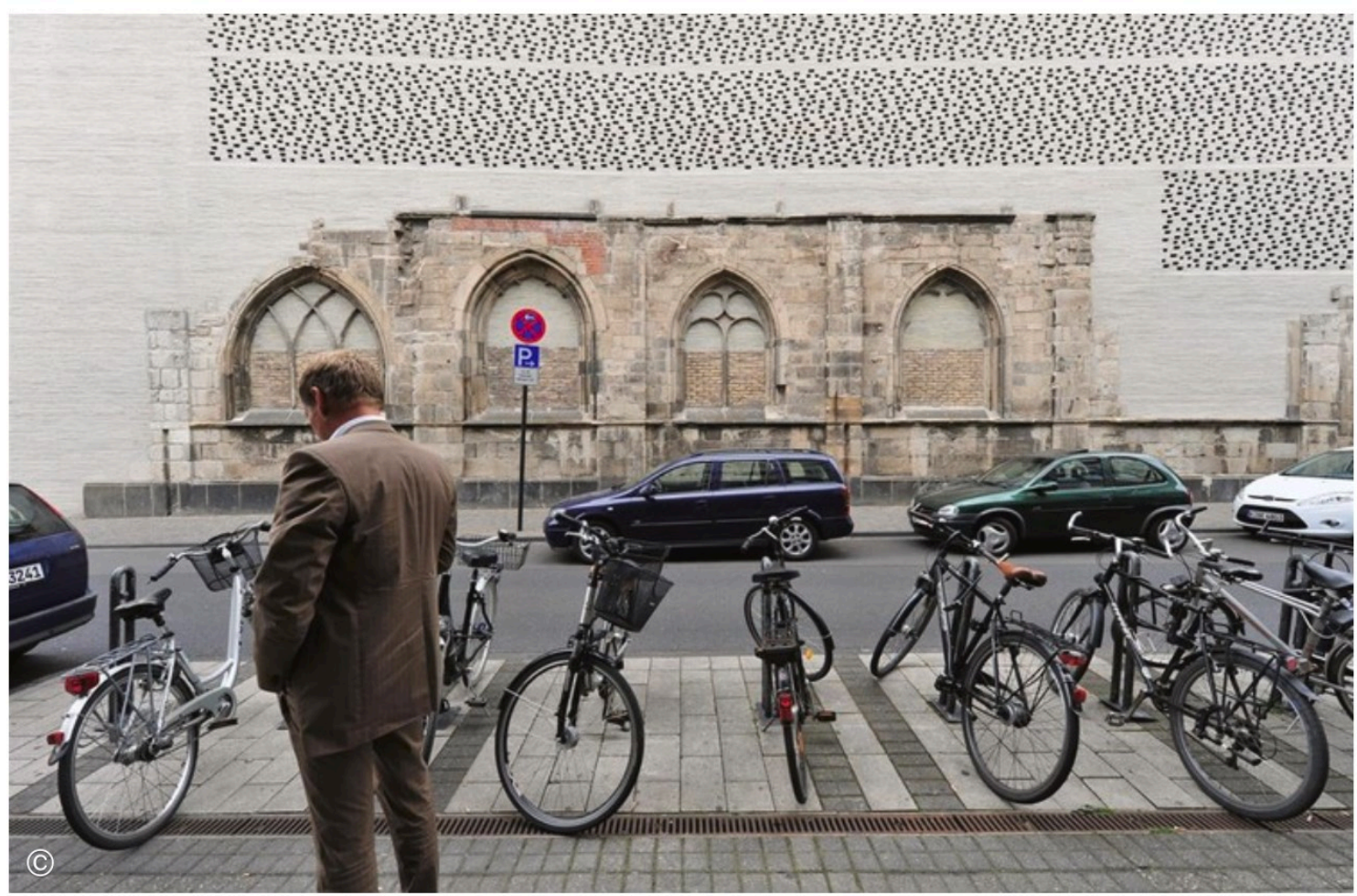

Nota: Vista exterior desde la calle de enfrente del museo.

Fuente: Archdaily, 2010. Peter Zumthor: Recuperación del Museo Kolumba. Recuperado de https://goo.gl/4YCF3H

La técnica constructiva para dicho proyecto son placas de concreto, con perforaciones por secciones para darle ligereza visual. El casco de concreto actúa como una protección externa que cubre toda la estructura antigua a manera de caparazón. Se sostiene únicamente por columnas similares a pilotes. 
Figura 4.41

Detalle esquemáticode pilotes del Museo de Kolumba

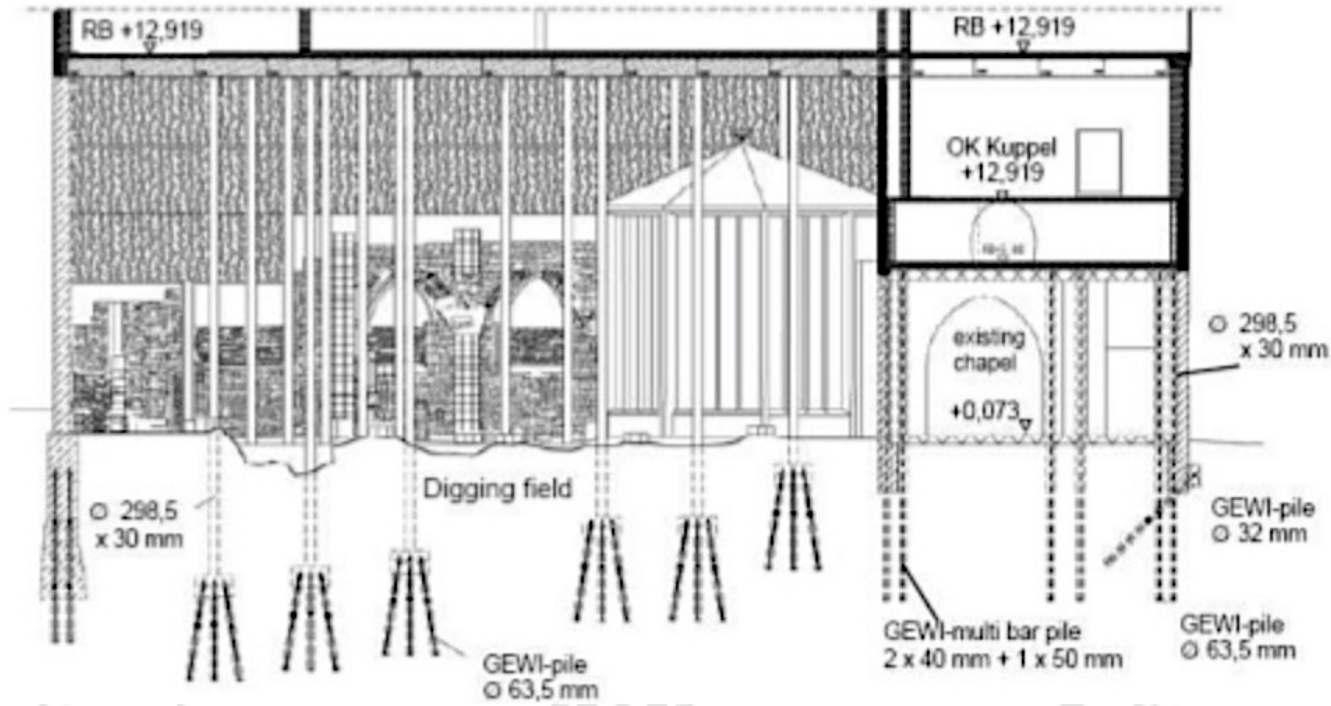

Nota: Esquema interior en corte del museo y su cimentación

Fuente: Senthil, 2014. Presentación del Museo Kolumba. Recuperado de https://goo.gl/L3nkz1

Por otro lado, el Museo del Louvre, usa la tecnología conocida como arañas de acero y cables de acero.

Figura 4.42

Detalle de araña en encuentro perpendicular
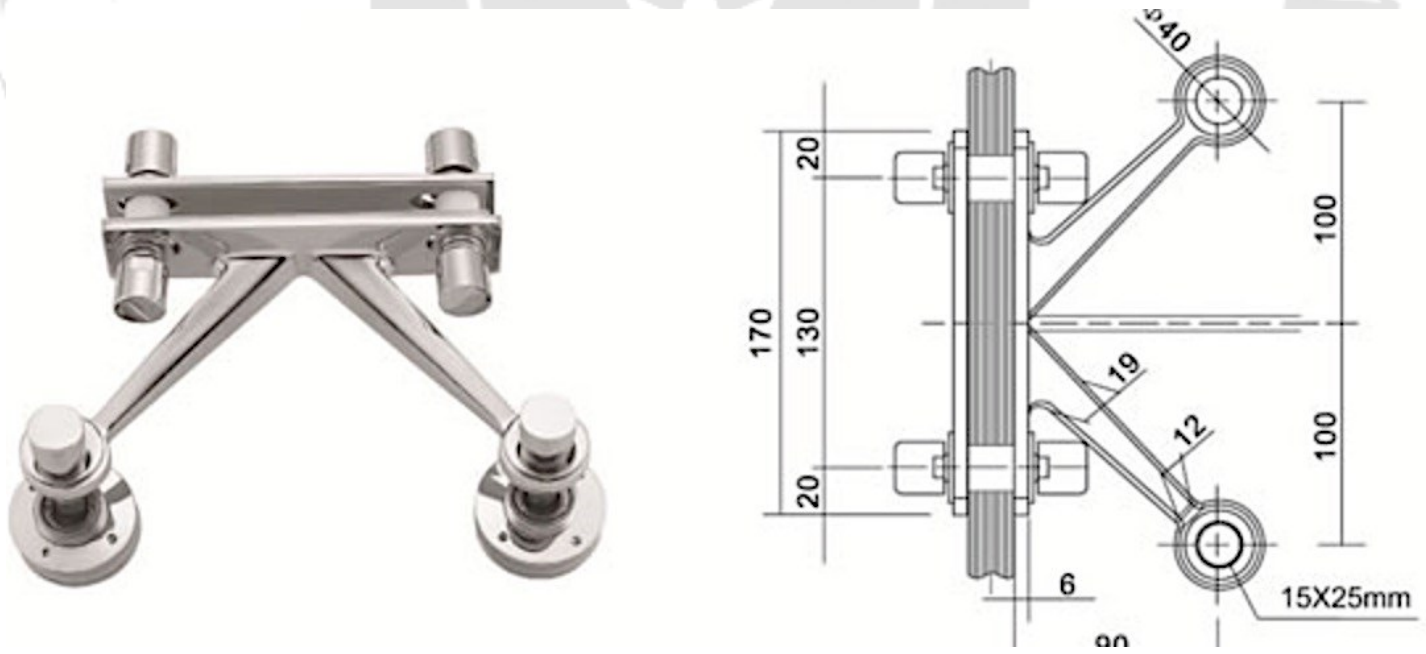

Nota: Detalle en imagen digital y plano de sección de araña de encuentro perpendicular

Fuente: CY Industry Ltd, 2007. Arañas de acero. Recuperado de https://goo.gl/RC55P6 
Figura 4.43.

Detalle de araña de acero simple

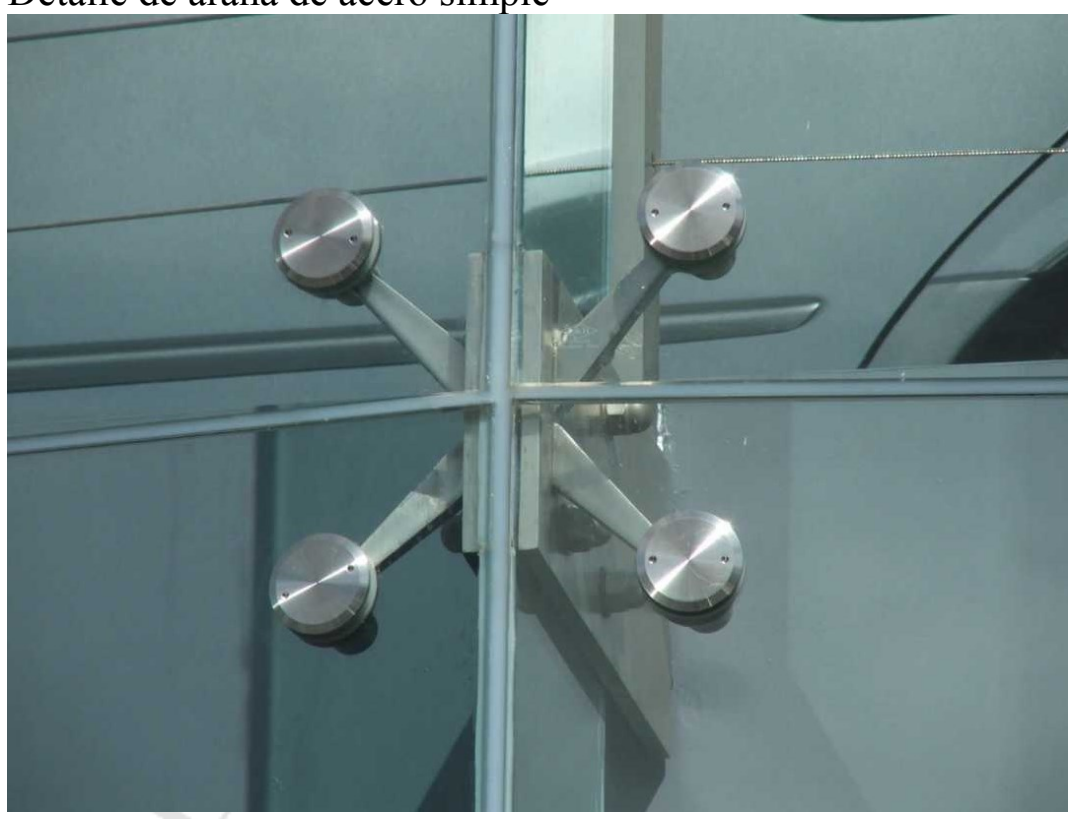

Nota: Imagen de araña simple colocada para sostener 4 secciones de vidrio distintas.

Fuente: Dongying Zhengda Metal Product Co. Ltd., 2016. Arañas de soporte metálico. Recuperado de https://goo.gl/LxZs6S

Figura 4.44.

Vista de las arañas y cables de acero

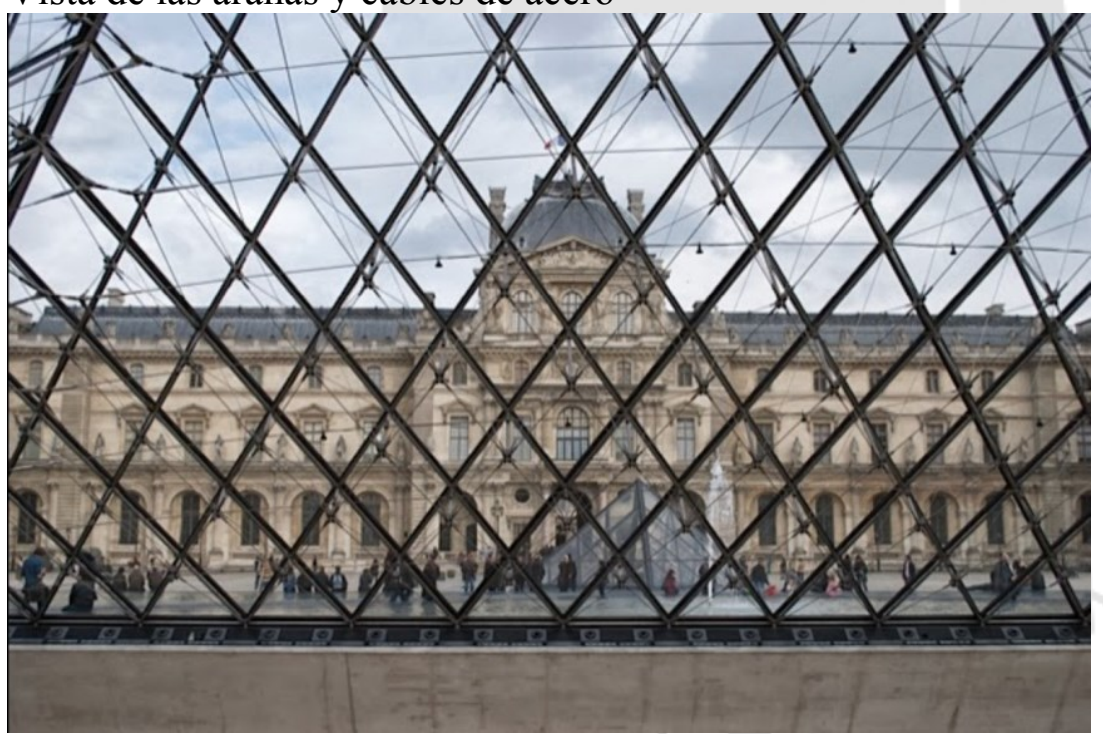

Nota: Imagen de interior de la piramide donde se observan las arañas de acero y cables que la sostienen.

Fuente: History Undressed, 2013. The Louvre. Recuperado de https://goo.gl/IZdzkq

El Centro Cultural de la Moneda, así como el Museo Judío de Berlín utilizan una combinación de concreto con acero, para generar luces largas de vidriadas. Además, en la obra de Undurraga, el uso de rampas únicamente sostenidas por esbeltas columnas es esencial para permitir dar el efecto de ligereza de deseado por el proyectista. 
Figura 4.45

Axonometría de niveles de vigas principales

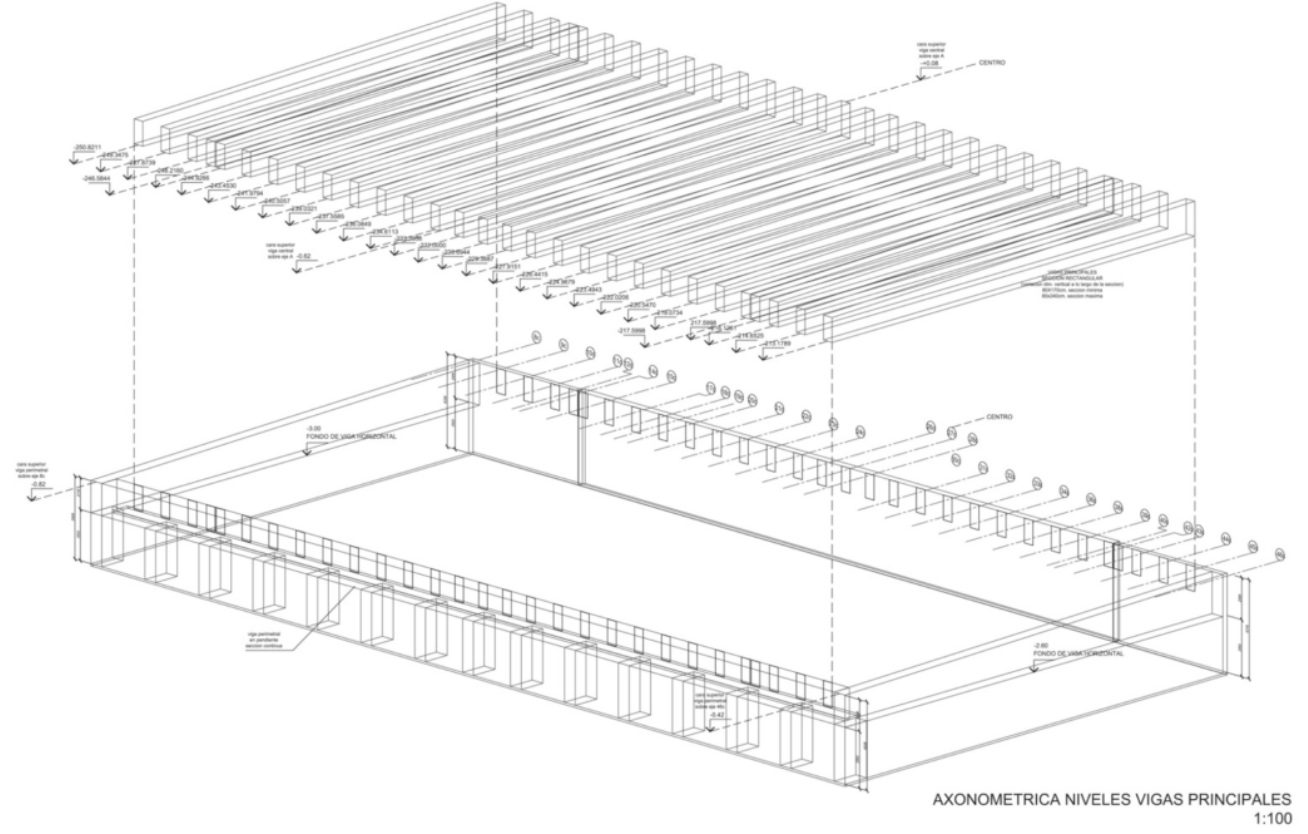

Nota: Axonometría explotada de los niveles de vigas principales debajo de la plaza de la Ciudadanía Fuente: Archdaily, 2006. Centro Cultural Palacio La Moneda y Plaza de la Ciudadanía / Undurraga Devés Arquitectos. Recuperado de https://goo.gl/rLPaSQ

Por otro lado, el museo Judío utiliza paredes de alucobon y zinc para generar las sensaciones deseadas, como recogimiento y melancolía, en cada ambiente.

Figura 4.46

Sección de rampas

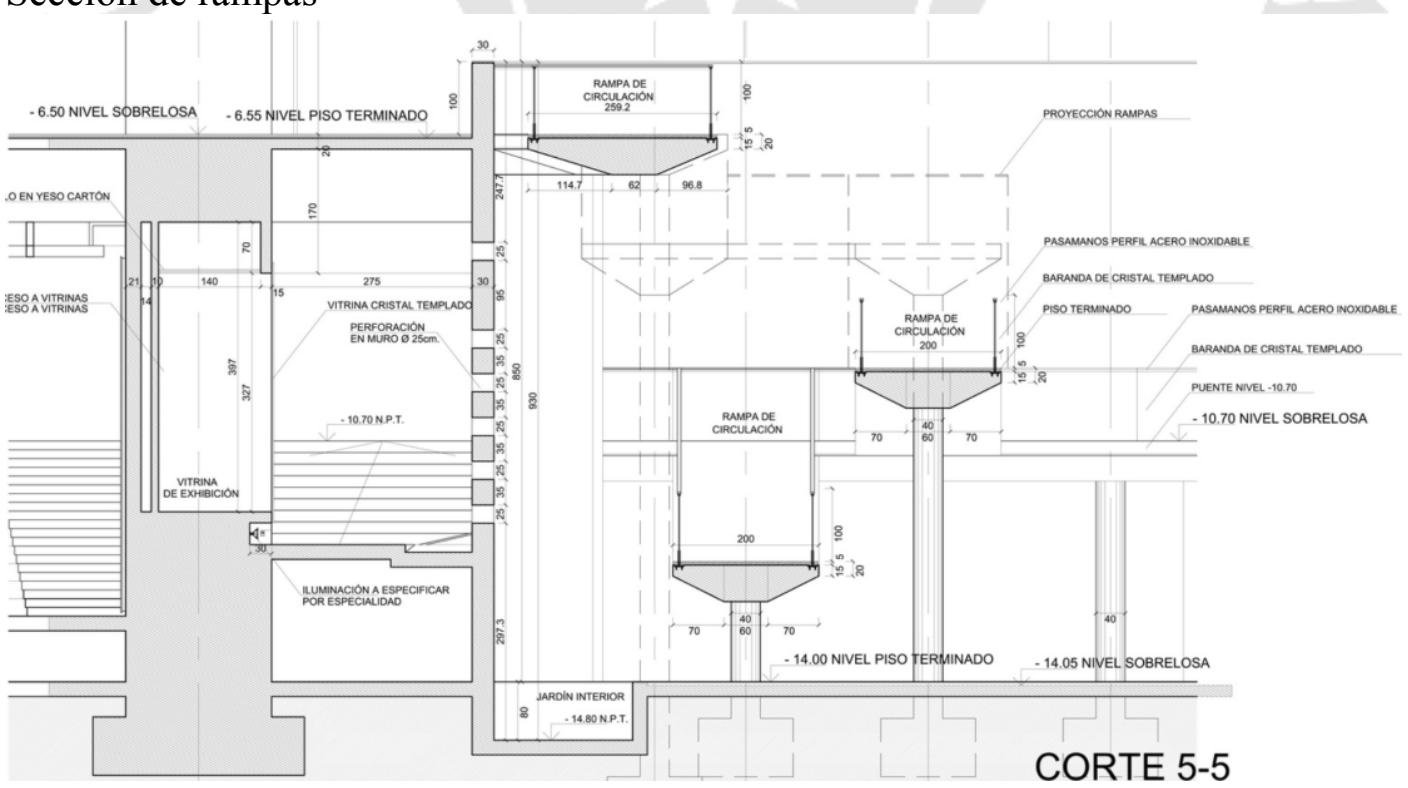

Nota: Sección de rampas de ingreso debajo de la plaza de la Ciudadanía

Fuente: Archdaily, 2006. Centro Cultural Palacio La Moneda y Plaza de la Ciudadanía / Undurraga Devés Arquitectos. Recuperado de https://goo.gl/rLPaSQ 
Figura 4.47

Escaleras interiores
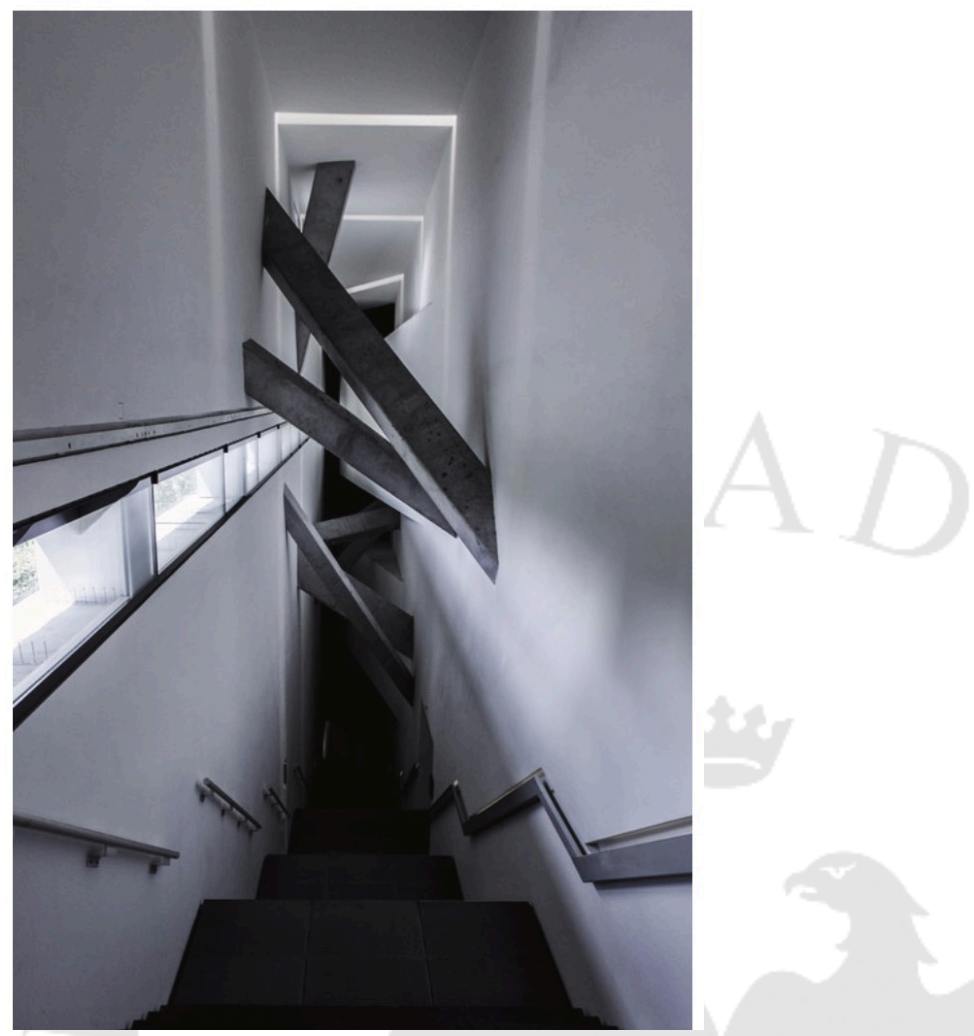

Nota: Barras de alucobón atraviesan de lado a lado las paredes de concreto del Museo Judío de Berlín

Fuente: Archdaily, 2015. Museo Judio, Berlín / Daniel Libenskind. Recuperado de https://goo.gl/CySooe

Figura 4.48

Sala de exhibición en segundo piso

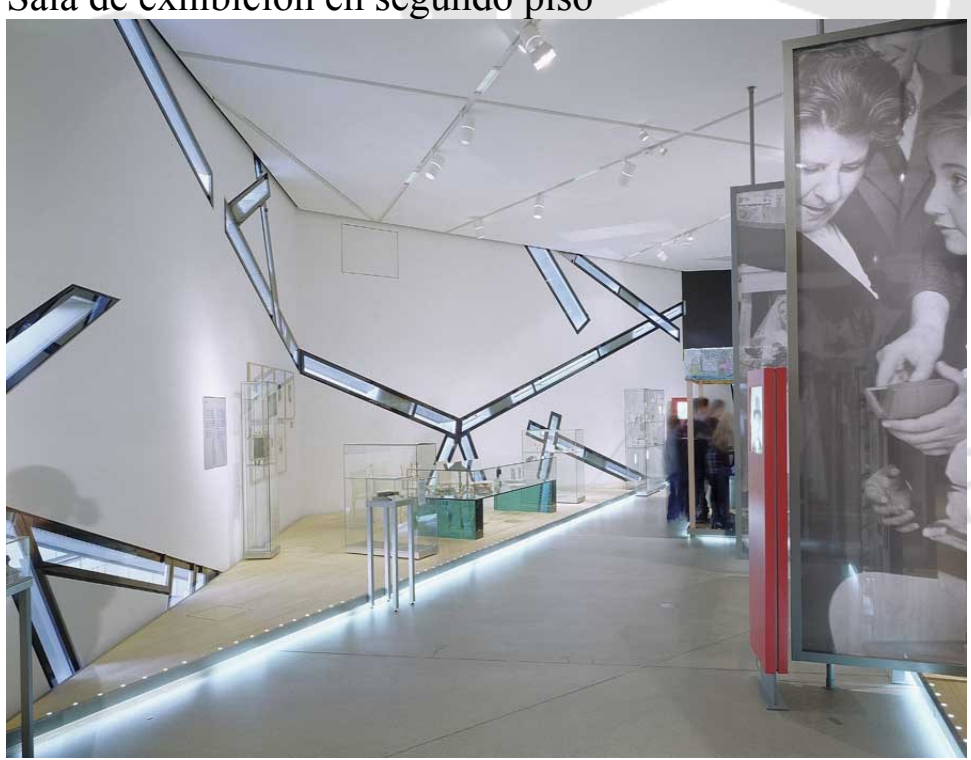

Nota: Interior de la sala de exhibición del museo recubierta en alucobón

Fuente: Archdaily, 2015. Museo Judio, Berlin / Daniel Libenskind. Recuperado de https://goo.gl/CySooe 


\subsubsection{Impacto social}

El radio de impacto de todos los proyectos estudiados es metropolitano; sin embargo, por la calidad del proyecto, el reconocimiento del arquitecto, y por las colecciones que albergan, han llegado a adquirir fama mundial.

En el caso del Museo de Kolumba, por ejemplo, cumple con la función de regenerar de un edifico antiguo que se encontraba en estado de abandono, y lo pone en valor. Además, crea un espacio de encuentro a través de la recuperación de la memoria histórica de la comunidad.

Así también, el Museo Judío de Berlín cumple la doble función de espacio expositivo, y a la vez de reflexión y meditación por medio de los distintos ambientes ordenados a lo largo del circuito. También es un lugar para recordar y vivir el duelo de las generaciones pérdidas durante la guerra.

Por otro lado, la pirámide de Pei en el patio Museo Louvre sirve como activador social y comercial, y marca el principal ingreso al recorrido. Dicha intervención ha tenido tal impacto en la memoria colectiva francesa que actualmente es imposible concebir el Louvre sin su pirámide.

Por último, el Centro Cultural de la Moneda, busca recuperar un espacio que era usado como estacionamiento de trabajadores del gobierno. Así, logra crear gran actividad cultural bajo el nivel de la calle, a través de salas de exhibición, auditorio y tiendas. Lamentablemente, el piso de vidrio sobre toda la estructura no permite tránsito, por lo que la nueva plaza generada frente al Palacio de la Moneda permanece con un uso muy limitado. 
Tabla 4.5

Comparación de proyectos de referencia - Museo Judío de Berlín

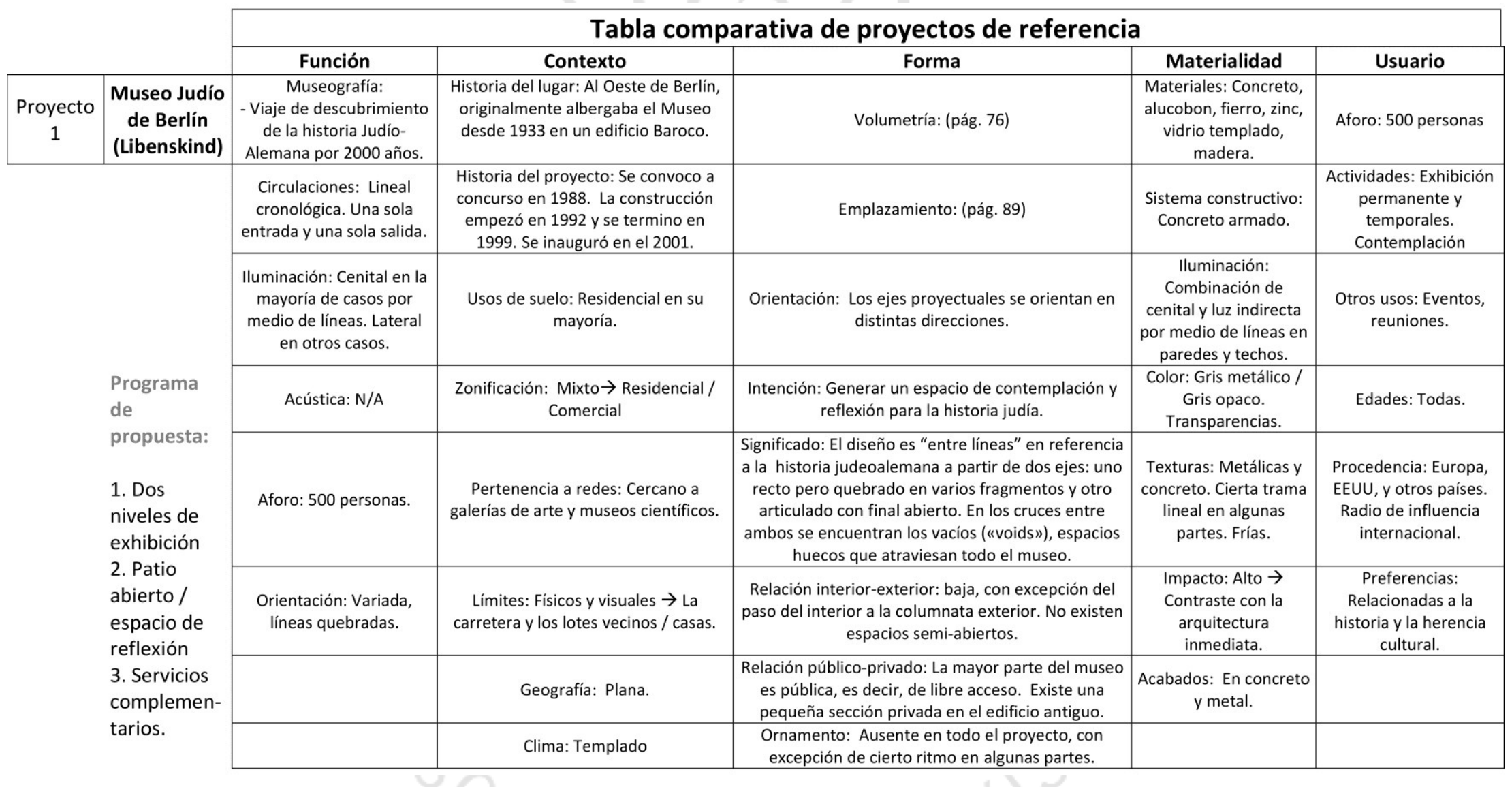

Nota: Descripción de función, contexto, forma, materialidad y usuario del Museo Judío de Berlín

Fuente: Elaboración propia, 2017 
Tabla 4.6

Comparación de proyectos de referencia - Museo de Louvre (ampliación de Pei)

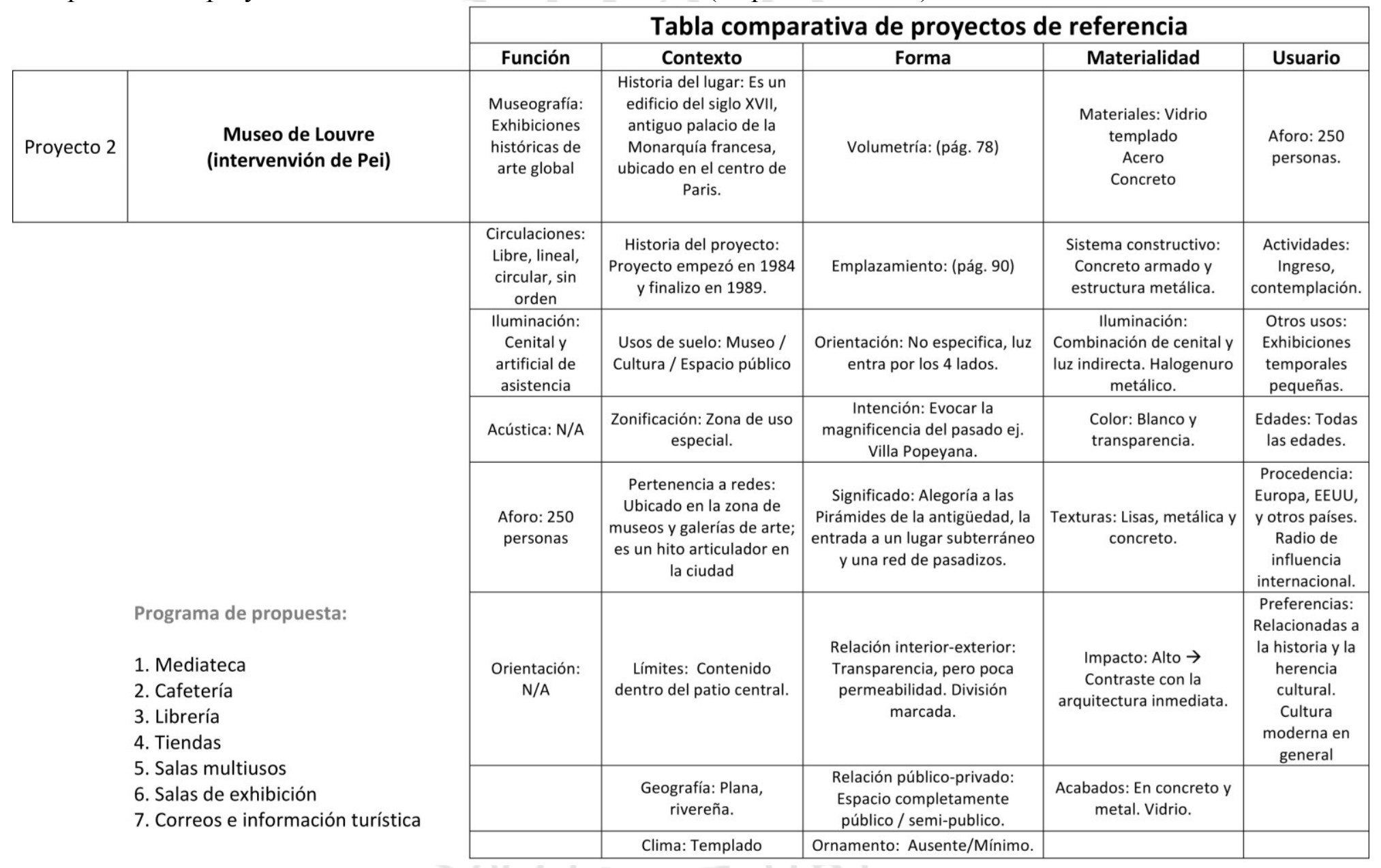

Nota: Descripción de función, contexto, forma, materialidad y usuario del Museo de Louvre

Fuente: Elaboración propia, 2017 
Tabla 4.7

Comparación de proyectos de referencia - Museo de Kolumba

\begin{tabular}{|c|c|c|c|c|c|c|}
\hline \multirow[b]{3}{*}{ Proyecto 3} & \multirow[b]{3}{*}{$\begin{array}{l}\text { Museo } \\
\text { Kolumba } \\
\text { (Zumthor) }\end{array}$} & \multicolumn{5}{|c|}{ Tabla comparativa de proyectos de referencia } \\
\hline & & Función & Contexto & Forma & Materialidad & Usuario \\
\hline & & $\begin{array}{l}\text { Museografía: Arte } \\
\text { antiguo religioso y } \\
\text { contemporáneo }\end{array}$ & $\begin{array}{c}\text { Historia del lugar: Localizado sobre } \\
\text { una antigua iglesia destruida } \\
\text { durante la segunda guerra } \\
\text { mundial. }\end{array}$ & Volumetría: (pág. 82) & $\begin{array}{l}\text { Materiales: Concreto } \\
\text { armado y ladrillo. }\end{array}$ & Aforo: 300 personas. \\
\hline & \multirow[b]{3}{*}{$\begin{array}{l}\text { Programa de } \\
\text { propuesta: }\end{array}$} & $\begin{array}{l}\text { Circulaciones: } \\
\text { Lineal, dividida en } \\
\text { tres pisos. }\end{array}$ & $\begin{array}{l}\text { Historia del proyecto: } \\
\text { Se construyo entre el } 2003 \text { y el } \\
2007 \text { como parte de la } \\
\text { recuperación del área. }\end{array}$ & Emplazamiento: (pág. 90) & $\begin{array}{l}\text { Sistema constructivo: } \\
\text { Concreto armado y plazas } \\
\text { / Muros de ladrillo. }\end{array}$ & $\begin{array}{l}\text { Actividades: } \\
\text { Exhibición } \\
\text { permanente y } \\
\text { temporales. } \\
\text { Contemplación }\end{array}$ \\
\hline & & $\begin{array}{l}\text { lluminación: A } \\
\text { través de patios y } \\
\text { jardines. Pequeños } \\
\text { agujeros en fachada. }\end{array}$ & Usos de suelo: Cultural / museo & Orientación: N/A & $\begin{array}{l}\text { lluminación: A través de } \\
\text { patios interiores. Lateral. }\end{array}$ & $\begin{array}{l}\text { Otros usos: Eventos } \\
\text { en auditorio. }\end{array}$ \\
\hline & & Acústica: N/A & $\begin{array}{l}\text { Zonificación: Zona de uso } \\
\text { especial. }\end{array}$ & $\begin{array}{l}\text { Intención: Fusionar las ruinas de una } \\
\text { iglesia católica destruida con una } \\
\text { arquitectura moderna, sobria, } \\
\text { minimalista y altamente sensible al tema } \\
\text { que acoge: el arte religioso. }\end{array}$ & Color: Blanco y gris. & $\begin{array}{l}\text { Edades: Adultos en sL } \\
\text { mayoría. }\end{array}$ \\
\hline & \multirow{4}{*}{$\begin{array}{l}\text { 1. Tienda } \\
\text { 2. Cafetería } \\
\text { 3. } 3 \text { salas } \\
\text { temporales } \\
\text { 4. Centro de } \\
\text { aprendizaje } \\
\text { 5. } 2 \text { salas } \\
\text { permanentes }\end{array}$} & Aforo: 300 personas & $\begin{array}{l}\text { Pertenencia a redes: en zona } \\
\text { histórica de museos. }\end{array}$ & $\begin{array}{l}\text { Significado: La continuidad y contraste } \\
\text { entre lo antiguo y lo nuevo. }\end{array}$ & $\begin{array}{l}\text { Texturas: Liso y en otras } \\
\text { partes irregular. }\end{array}$ & $\begin{array}{l}\text { Procedencia: Locales } \\
\text { y Europeos. Radio de } \\
\text { influencia regional. }\end{array}$ \\
\hline & & Orientación: N/A. & Límites: físicos, alrededor del lote. & $\begin{array}{l}\text { Relación interior-exterior: Ligera } \\
\text { permeabilidad, al exterior; sin embargo } \\
\text { gran permeabilidad }\end{array}$ & $\begin{array}{l}\text { Impacto: Alto } \rightarrow \\
\text { Contraste y equilibrio con } \\
\text { la arquitectura inmediata. }\end{array}$ & $\begin{array}{l}\text { Preferencias: Arte } \\
\text { contemporáneo y } \\
\text { antiguo histórico. } \\
\text { Interés por el } \\
\text { patrimonio. }\end{array}$ \\
\hline & & & Geografía: Plana & $\begin{array}{l}\text { Relación público-privado: Espacio publico } \\
\text { con sala semipúblicas. }\end{array}$ & $\begin{array}{l}\text { Acabados: Sencillos, } \\
\text { detalles en cemento. }\end{array}$ & \\
\hline & & & Clima: Templado. & $\begin{array}{l}\text { Ornamento: Decoración propia de las } \\
\text { muestras. }\end{array}$ & & \\
\hline
\end{tabular}

Nota: Descripción de función, contexto, forma, materialidad y usuario del Museo de Kolumba

Fuente: Elaboración propia, 2017 
Tabla 4.8

Comparación de proyectos de referencia - Centro Cultural de La Moneda

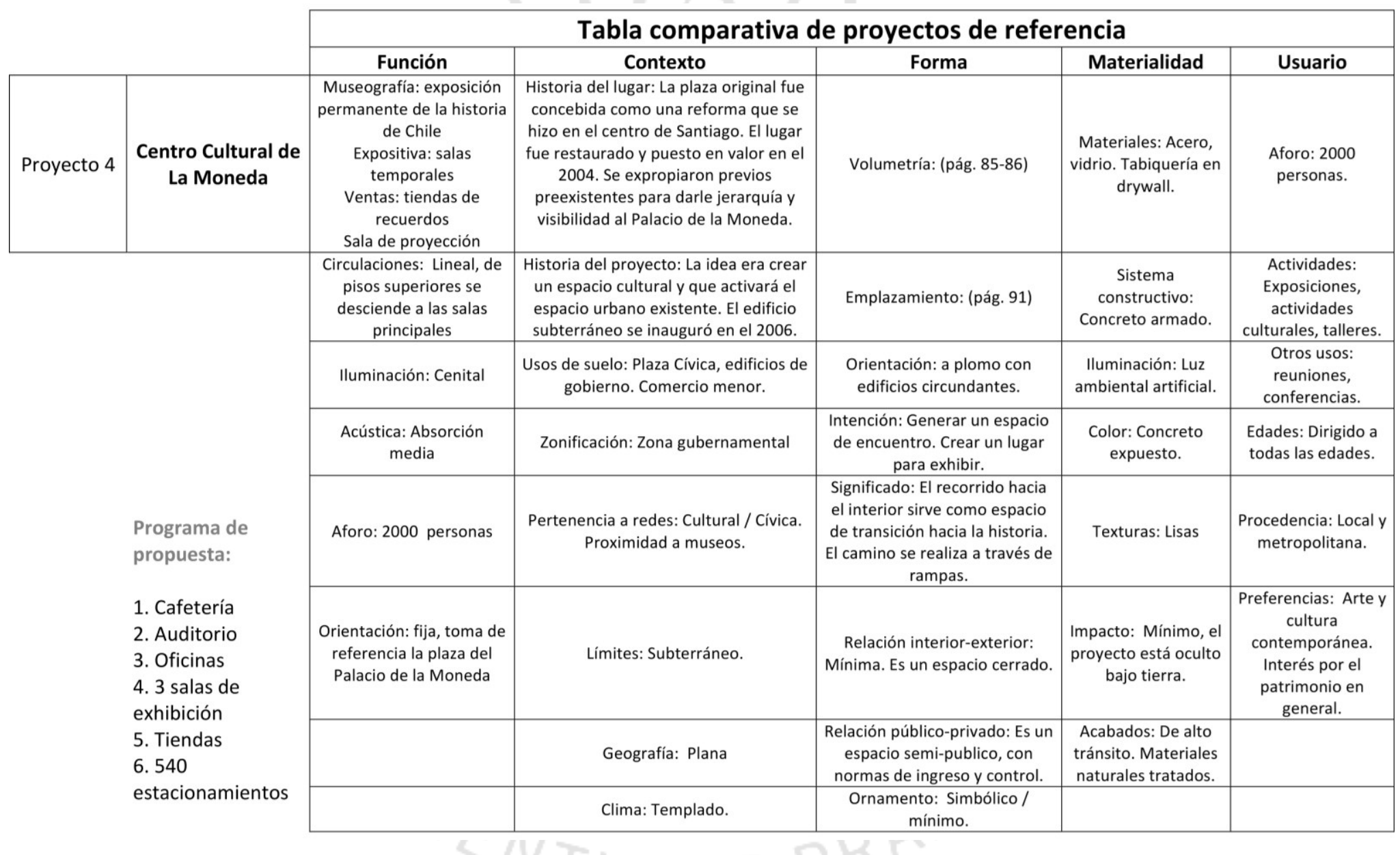

Nota: Descripción de función, contexto, forma, materialidad y usuario del Centro Cultural de la Moneda

Fuente: Elaboración propia, 2017 


\subsection{Conclusiones parciales}

Según Ruskin, "en la arquitectura, esta honestidad radica en la medida en que se manifiesten y logren los elementos esenciales de la construcción”. (Ruskin, 2006, pp. 105-113).

Ruskin postula 7 verdades o "lámparas" sobre la arquitectura:

- El sacrificio: el edificio debe mostrar el esfuerzo que tomó erigirse.

- La verdad: la estructura debe ser cumplir una función, al igual que la textura debe reflejar el origen del material.

- El poder: la capacidad de un edificio de ser querido y recordado con suavidad, o en su defecto, respetado y ajeno.

- La belleza: sólo el arquitecto a través de la abstracción y la proporción será capaz de crear algo bello.

- La vida: los detalles del edificio deben ser útiles, deben funcionar en conjunto para que sumen a la vida.

- La humildad y la obediencia: no debe intervenir un edificio sin tomar en cuenta lo ya iniciado por otro. Se debe respetar la historia del predio.

- La memoria: la arquitectura es el medio más poderoso para transmitir cultura, ya que el resto de artes pueden ser contenidos dentro de edificios u olvidados en el tiempo. La arquitectura es la creadora de ellos, en consecuencia, la edificadora de ciudades para la posteridad.

Si se analizan los referentes propuestos bajo estos criterios, se puede observar que solo uno de ellos falla con cumplir con "honestidad” su labor: el Museo Judío de Berlín. Este edificio (la intervención de Libenskind) es una especie de caja en forma de relámpago que contiene un programa y espacios plásticos que en realidad no son lo que son; sirven únicamente para transmitirle al visitante las sensaciones que el arquitecto pensó. Dicho ello, ¿es importante la "honestidad" al estilo de Ruskin en los museos? En la actualidad, bajo la visión de arquitectos (Kuon, 2015) y conservadores entendidos en el tema de la museografía, lo más importante en un museo es el "programa de necesidades", y se debe hacer todo lo posible para conseguir cubrirlas; de ser necesario, ocultar la realidad y crear una fantasía emocional y tangible.

Entonces, la pregunta debe ser: ¿qué tanto está dispuesto a hacer el profesional para alcanzar su objetivo?; esto ya queda a total criterio y conocimiento del grupo de personas e instituciones responsables de la intervención. Empero, lo más importante siempre será respetar (de manera crítica) la memoria de un edificio, que no está en un ladrillo o en una columna; está en la calidad espacial y sensorial del monumento, esa es su esencia. 


\section{CAPÍTULO V: MARCO CONTEXTUAL}

\subsection{El lugar y su contexto}

\subsubsection{LOCUS \& GENIUS LOCI:}

Según Aldo Rossi, “todas las formas urbanas son capaces de incorporar funciones si es que son alterados o modificados de alguna manera" (Rossi, 1995, p. 77). En es caso, se busca transformar este espacio muerto y separado de la ciudad en una plaza abierta hacia la comunidad que sirva para recuperar la esquina en la que se encuentra y que sufre de altos índices de contaminación visual y auditiva, además de delincuencia.

Este nuevo espacio que albergará salas de exhibición busca dinamizar y activar su entorno, por lo que un aspecto fundamental será la creación de una plaza a nivel de suelo obligue al edificio a hundirse y así no competir con el Museo en sí. Todo el programa se desarrollará en un nivel subterraneo para mantener el "espíritu del lugar" que está relacionado con historía e identidad que están en riesgo de perderse.

El lugar elegido para la ampliación del MALI es único y concentra la memoría de uno de los lugares más emblemáticos del centro histórico. Las condiciones y cualidades patrimoniales de este espacio deben ser conservadas.

\subsubsection{CONTEXTO:}

Según Caniggia y Maffei, existe una "relación espontánea codificada entre el ambiente y la obra de cada individuo, a través de la colectividad" (Norberg-Schulz, 1975, p. 7). En otras palabras, los edificios circundantes y el mismo MALI son reflejo de un contexto; asimismo el estado actual del lugar a intervenir también es el resultado la precaría situación en el que se encuentra.

Por ello, para poder tomar decisiones de diseño se tomará muy en cuenta el contexto histórico de este espacio; desde los edificios hasta la materialidad y vegetación local. Está ampliación debe reflejar la relación entre el todo (la ciudad) y sus partes (los edificios).

\subsection{Situación actual}

En la actualidad existen 338 museos en el Perú, de los cuales 45 se encuentran en Lima, 37 públicos y 8 privados. (Ministerio de Cultura, 2012). El museo más importante y 
visitado por turistas nacionales e internacionales a la fecha es el Museo de Arte de Lima, con un record de 21000 visitantes en siete días por fiestas patria. (Gerencia MALI, 2016)

Por otro lado, según el INEI ${ }^{24}$, el Museo Nacional de Arqueología del Perú es el museo público más visitado anualmente, con más de 150000 asistentes en el 2011. (Instituto Nacional de Estadística e Informática, 2014).

A pesar de contar con estas cifras relativamente alentadoras, la situación de los museos es precaria, ya que muy pocos cuentan con una gestión adecuada o con el dinero para poder llevar a cabo las políticas y programas culturales que todo museo debe tener por sugerencia de la guía de la UNESCO ${ }^{25}$. Además, están muy lejos de llegar al millón de visitantes como la mayoría de museos importantes del Mundo.

Es así que el MALI, con el propósito de atraer más personas, empezó un proceso de recuperación y renovación de sus espacios en el año 2010 a través del plan $\mathrm{COPESCO}^{26}$ El proyecto se dividió en dos etapas, una que incluía el primer piso y la recuperación de $6000 \mathrm{~m}^{2}$ con la implementación de nuevas salas de exposición, talleres y una cafetería totalmente renovada. La segunda etapa está actualmente en obra e incluye el montaje definitivo de la muestra permanente del museo que incluye arte precolombino, colonial y republicano de gran valor histórico. Los trabajos fueron concluidos a fin del 2015. (Museo de Arte de Lima, 2016)

\subsubsection{Intervenciones y situación del Parque de la Exposición}

El Museo de Arte de Lima, construido en 1872, se encuentra en un jardín histórico de gran importancia patrimonial para la ciudad: El Parque de la Exposición. Este espacio urbano ha sido intervenido en varias ocasiones; la primera 1898, con la construcción del Paseo Colón, que pasa hasta el día de hoy frente a la fachada norte del edificio. (Joffré, 2007). En 1921, cuando distintas legiones internacionales residentes en Lima donaron piezas de arquitectura y esculturas que fueron colocadas en distintas partes del parque.

Luego, en los años 50's y 70's se ampliación las vías circundantes a este espacio ${ }^{27}$, lo que resultó en la mutilación y la fragmentación del mismo. (Canziani, 2014)

\footnotetext{
${ }^{24}$ INEI: Instituto Nacional de Estadística e Informática del Perú

${ }^{25}$ La Organización de las Naciones Unidas para la Educación, la Ciencia y la Cultura se fundó el 16 de noviembre de 1945. Su objetivo es la observancia de los derechos humanos, el respeto mutuo y la reducción de la pobreza.

${ }^{26}$ COPESCO: Plan de Cooperación Especial por Convocatorias, es un plan del Gobierno Peruano por el cual canaliza fondos internacionales destinados a la Cultura y la protección del Patrimonio.

${ }^{27}$ La avenida Alfonso Ugarte, 28 de julio y la Avenida Colón fueron ampliadas, separando al Parque de la Exposición del Parque del Museo Italiano por el Norte, y del Campo de Marte por el Sur. Además, la posterior construcción de la vía expresa del Paseo de la República termino por aislar al parque de distritos como la Victoria y Breña.
} 
Figura 5.1

Ampliación de la Av. Wilson en los años 50

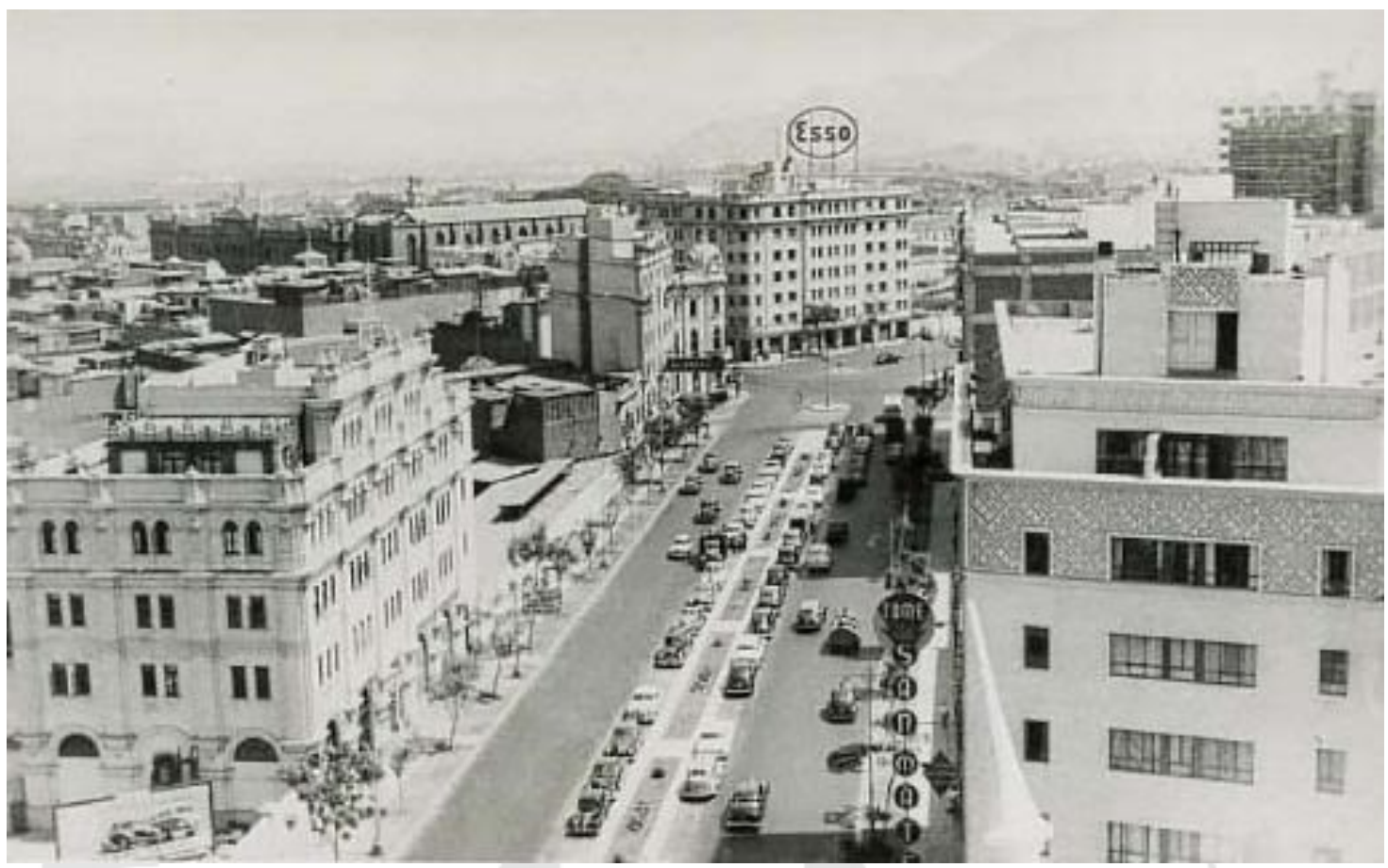

Fuente: Historia y Cultura Peruana, 2009. Como fue Lima. Recuperado de https://goo.gl/FNyXE3

Figura 5.2

Construcción de la vía expresa de Paseo de la República (primer tramo)

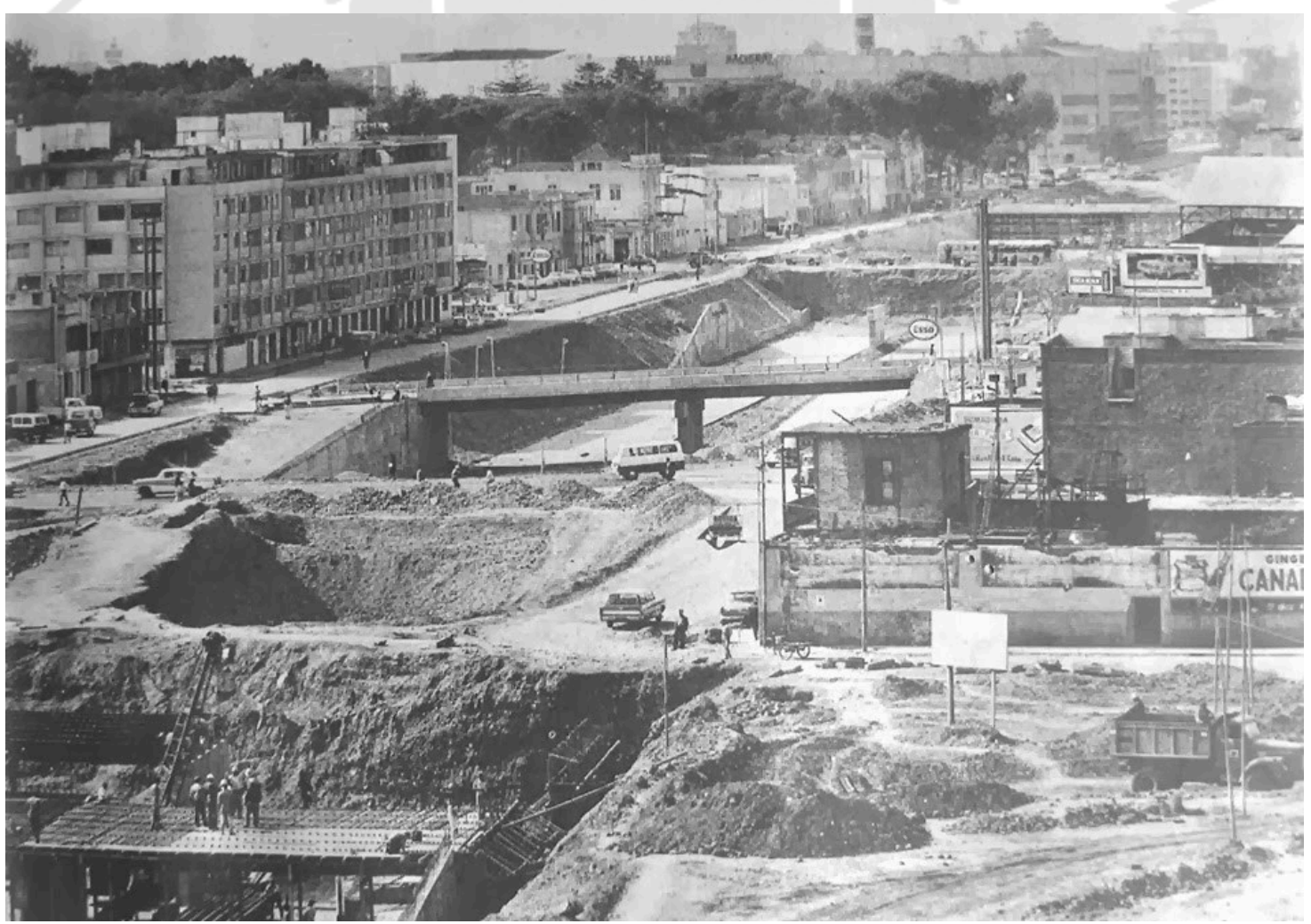

Fuente: Via Expresa Sur, 2014. Historia. Recuperado de http://www.viaexpresasur.pe/historia 
Finalmente, a fines de los 90's, el arquitecto Ortiz de Zevallos fue el encargado de la remodelación del parque. Se implementaron cafeterías, un anfiteatro al aire libre junto a la antigua "cabaña" y un espacio hundido donde se ubican talleres al frente de la fachada oeste del MALI. Este proyecto buscaba recuperar el parque, y rescatarlo del abandono que en el que se encontraba después de los años de terrorismo; lamentablemente, no lo ha conseguido y este espacio urbano aún sigue deteriorado y es usado para fines ajenos a su naturaleza patrimonial.

Figura 5.3

Vista del Parque de la Exposición desde el Museo Metropolitano

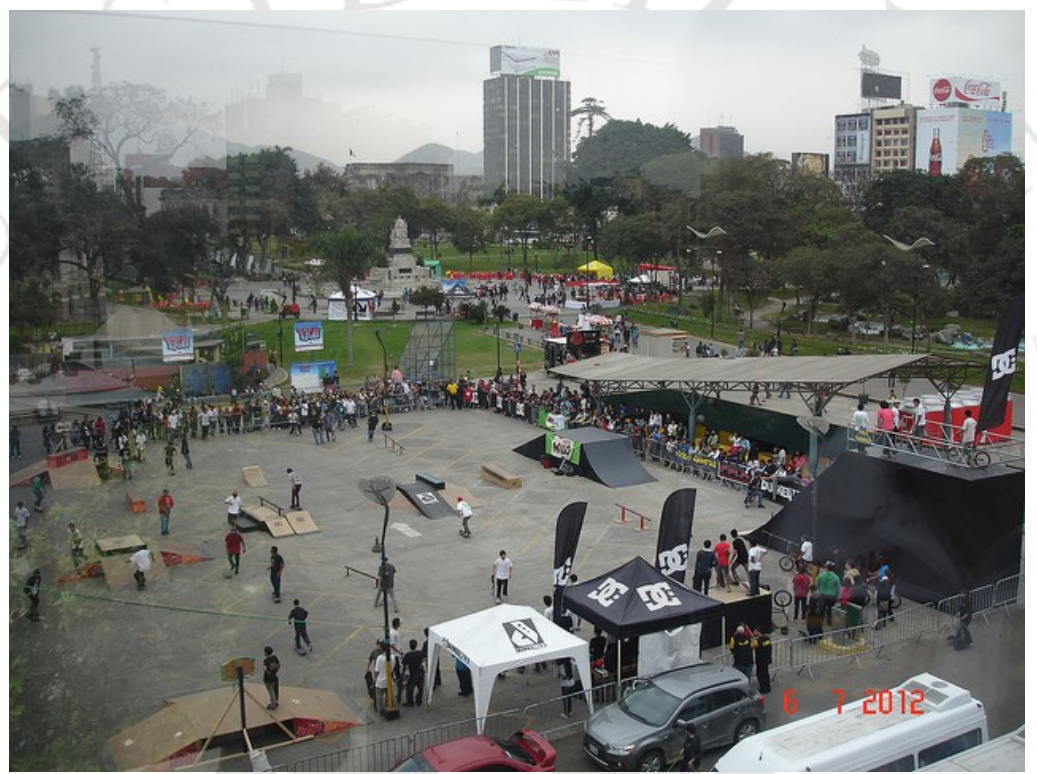

Fuente: Stucchi, 2012. Lima Parque de la Exposición. Recuperado de https://goo.gl/xp9K6y

Figura 5.4

Vista de lago japonés y anfiteatro del Parque de la Exposición

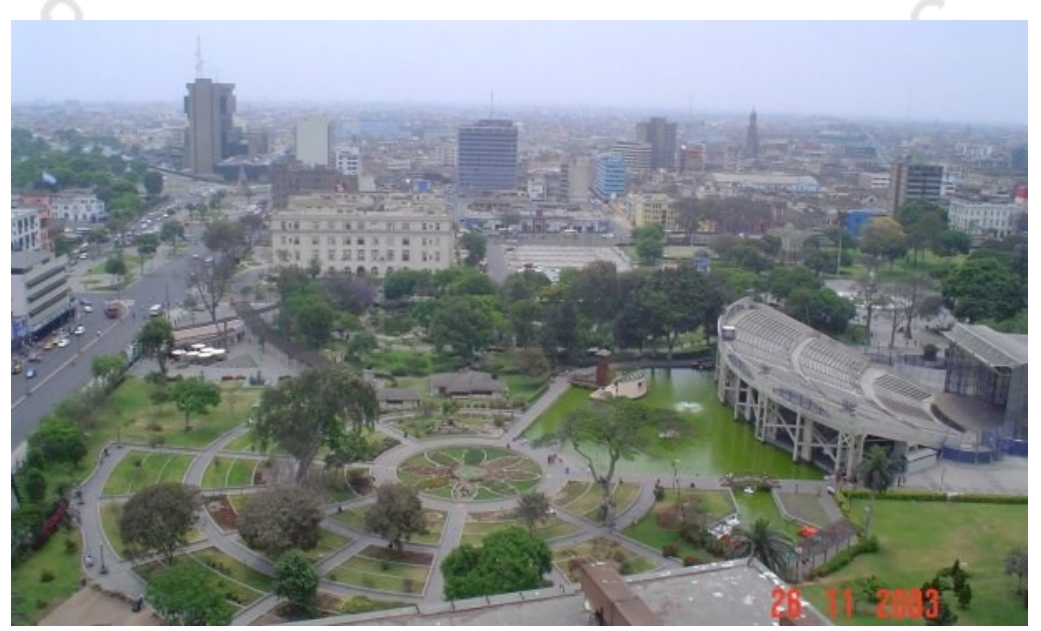

Fuente: Viajes y turismo, 2014. Las mejores fotos de Lima. Recuperado de https://goo.gl/hQxygV 


\subsection{Análisis del edificio}

\subsubsection{Museo de Arte de Lima (MALI)}

Se encuentra en el 125 de Paseo Colón, en Lima, dentro del Parque de la Exposición. El edificio construido en 1872 que alberga al museo, es uno de los ejemplos más bellos de la arquitectura ecléctica de la ciudad.

\section{Contexto}

\section{$\underline{\text { Historia }}$}

En 1954 se funda el Patronato de las Artes, cuyo objetivo fue el de promover la cultura y de darle a la ciudad un museo de arte, cosa que se obtiene en 1956 cuando el alcalde de aquel periodo otorga al patronato el Palacio de la Exposición, edificio que fue construido con fines expositivos entre los años 1870 y 1872.

Las labores de implementación y restauración del inmueble empezaron el mismo año en que fue entregado el inmueble, para luego ser inaugurado en 1956.

En 1961, las familias Prado y Peña Prado hacen entrega al museo de la colección "Memoria Prado". El presidente Manuel Prado Ugarteche inaugura las salas de exposición permanente 3,000 años de arte en el Perú, en la segunda planta del Palacio de la Exposición.

La remodelación del primer piso del museo y construcción del auditorio y biblioteca concluyen en 1986.

\section{Zonificación y uso de suelos}

El inmueble del museo pertenece a la zonificación de Uso especiales (gris), referida a actividades de gobierno, locales religiosos, cultura, entre otros.

La zonificación del entorno cruzando la Av. Inca Garcilaso de la Vega, corresponde a Zona de Tratamiento (naranja) por encontrarse en el centro histórico de Lima. Las zonas de color verde indican Zonas de Recreación Pública, en este caso el Parque de la Exposición. 
Figura 5.5

Zonificación del museo y alrededores

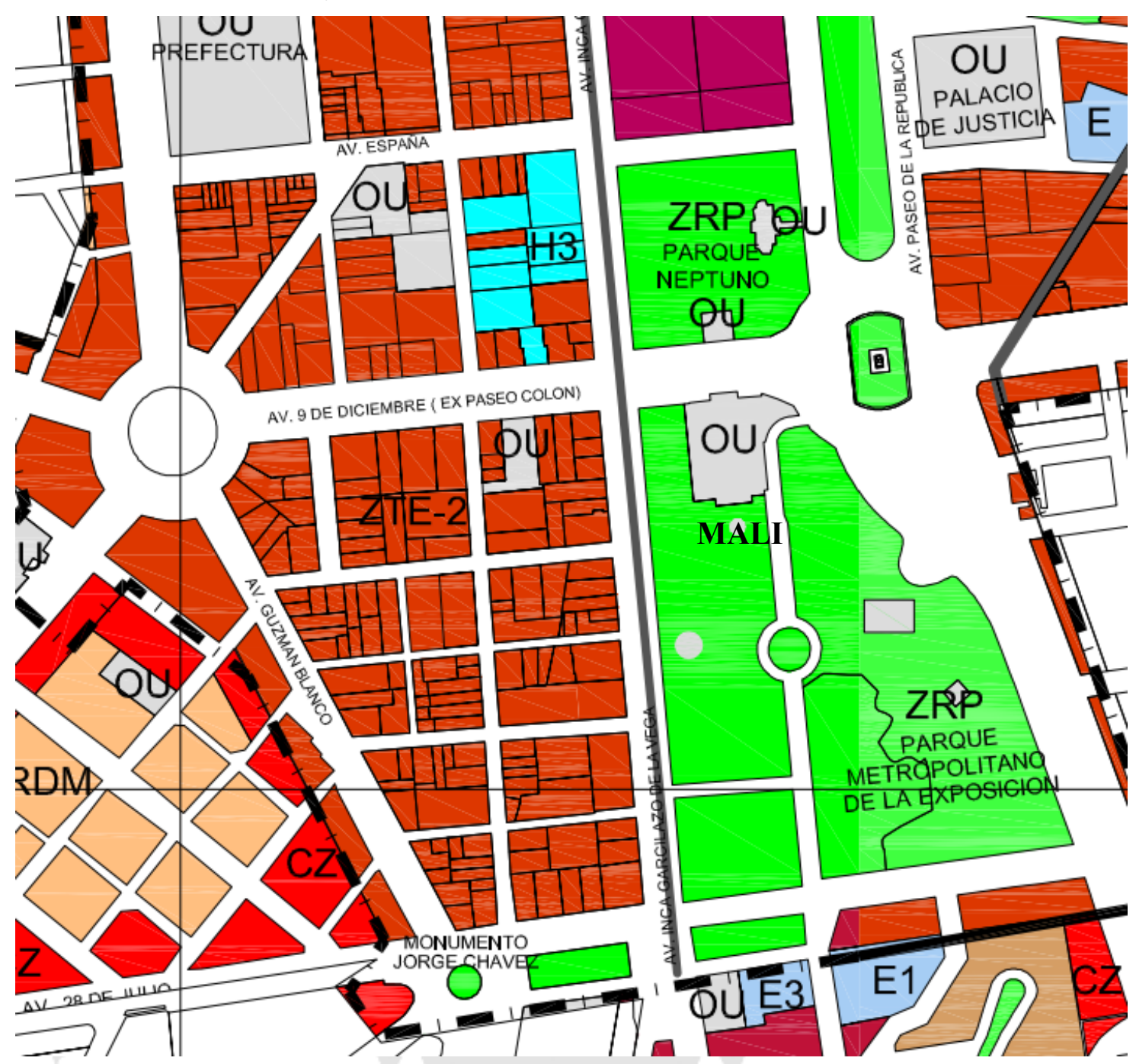

Nota: El Museo de Arte de Lima se ve como Otros Usos.

Fuente: Ministerio de Vivienda, 2007. Observatorio - 2 Zonificación del Cercado de Lima. Recuperado de https://goo.gl/XnombY

$\underline{\text { Accesos y límites }}$

El ingreso peatonal es a través Av. 28 de Julio (rojo) o Av. Paseo Colón (magenta). El ingreso vehicular y estacionamiento se ubica en la Av. 28 de Julio. 
Figura 5.6

Vías y límites de Parque de la Exposición

Leyenda:

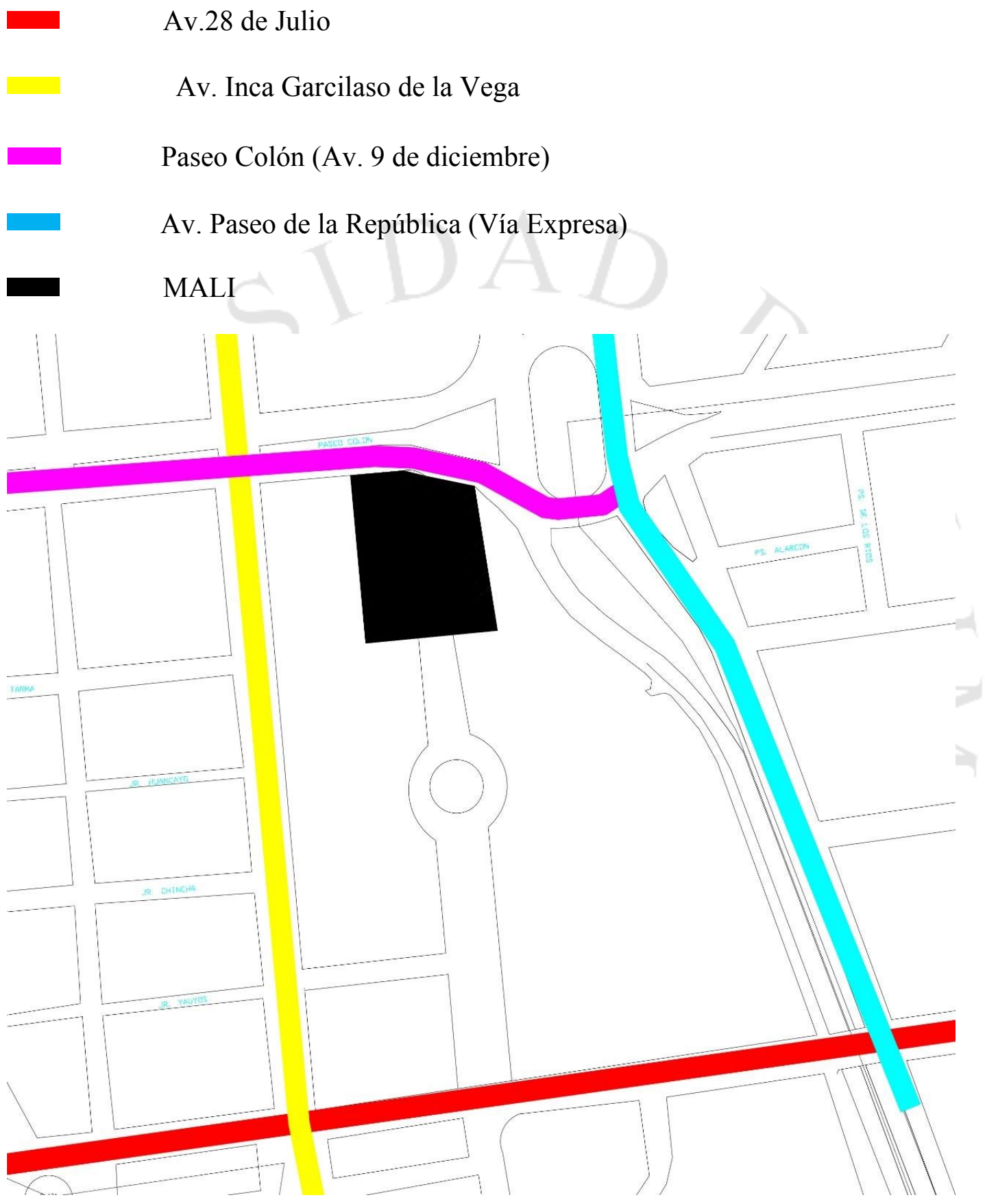

Escala: $1 / 5000$

Fuente: Elaboración propia, 2015

(1) 


\section{Función}

\section{$\underline{\text { Puesta museográfica }}$}

- Colección del primer nivel:

Salas de exposiciones temporales, con servicios complementarios como cafetería, baños y talleres. Además, las oficinas, depósitos y el auditorio del museo se encuentran también en este nivel.

- Colección del segundo nivel:

- Arte prehispánico, arte colonial, arte republicano, arte moderno y contemporáneo Figura 5.7

Axonometría de programa actual del MALI

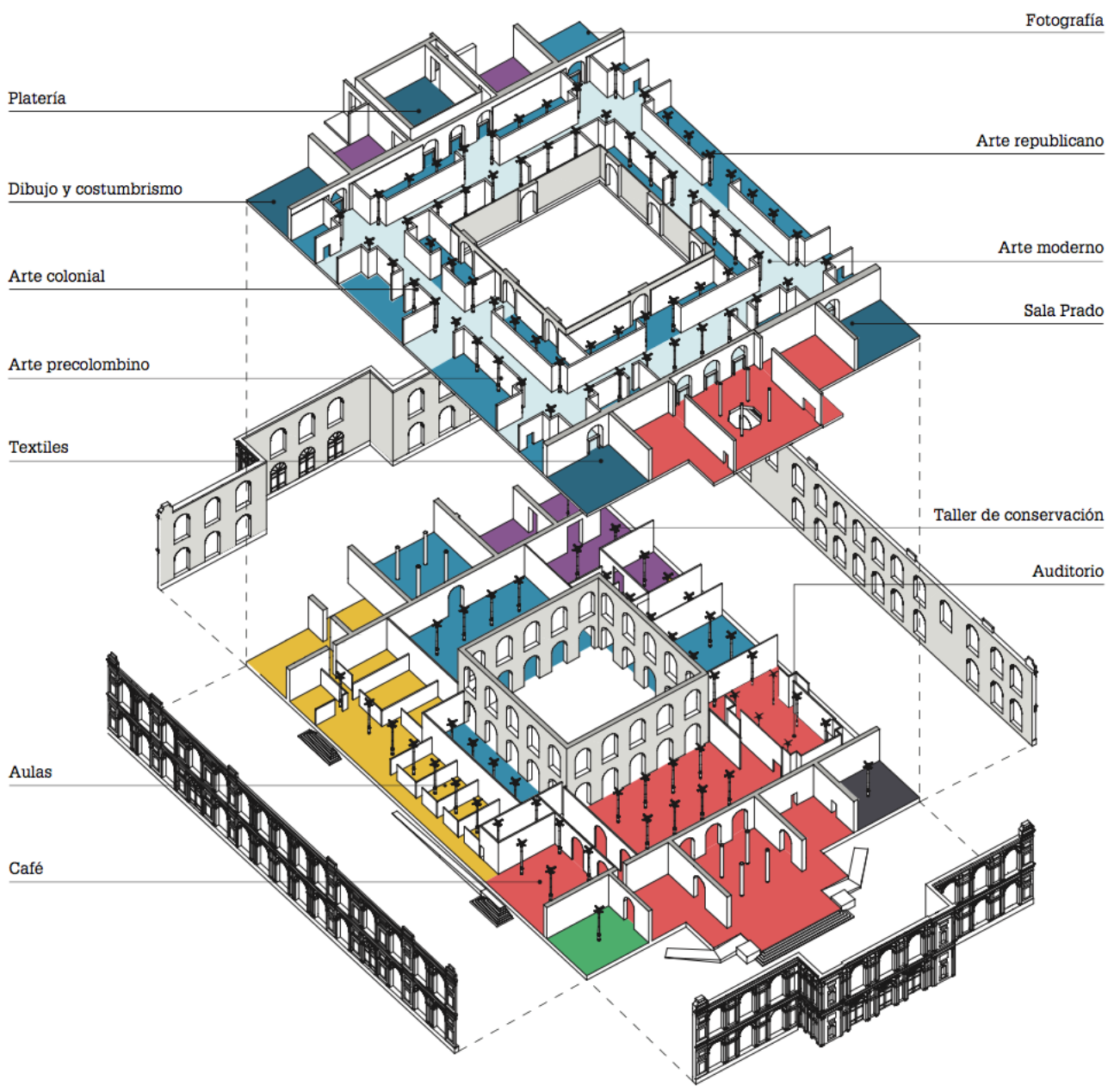




\section{Circulaciones}

Figura 5.8

Plano de circulación de la primera planta

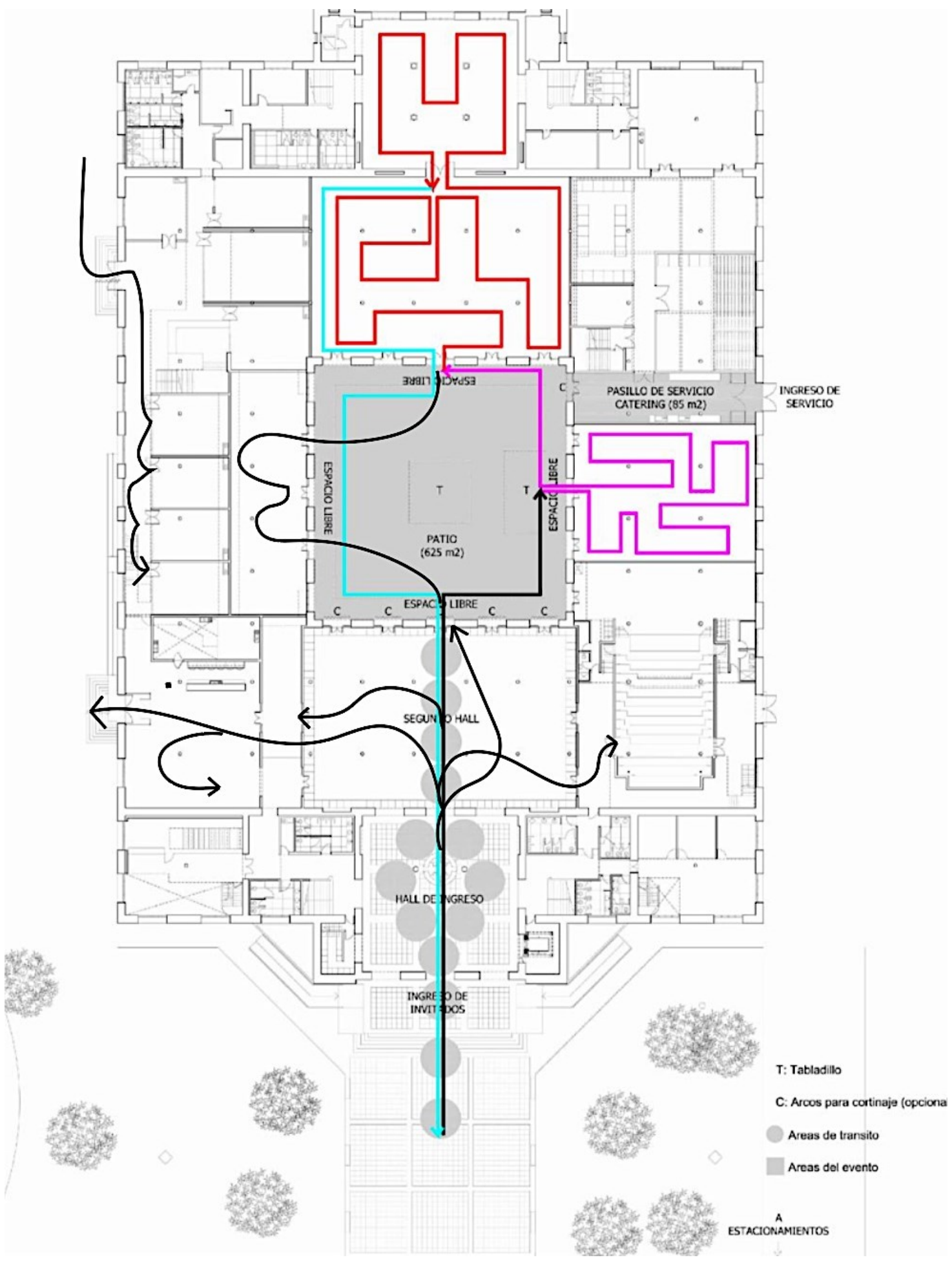

Nota: Escala 1/750

Fuente: Adaptado de Archivo MALI, 2015. 
La línea negra indica el ingreso hacia el museo a través del hall y el patio, el cual lleva a la sala 1 cuyo recorrido está representado por la línea de color magenta. La tabiquería interior genera un recorrido contemplativo lógico. Luego, se procede a ingresar a la sala 2 como se muestra con la línea roja. El recorrido finaliza y el usuario sale por la ruta en celeste.

Otras actividades

El MALI ofrece una gran cantidad de talleres al público en general entre los que se encuentran danzas de diferentes tipos, teatro, pintura, artes marciales entre otros. Existe un área subterránea frente a la fachada oeste del museo donde se encuentran aulas y unas graderías que sirven de anfiteatro al aire libre. Otras sucursales pedagógicas se encuentran en los distritos de La Molina y de forma temporal en Los Olivos, Pueblo Libre y Villa El Salvador.

El museo también sirve para eventos al aire libre en el anfiteatro lateral, y su patio central es rentado para matrimonios y eventos corporativos.

Figura 5.9

Talleres educativos

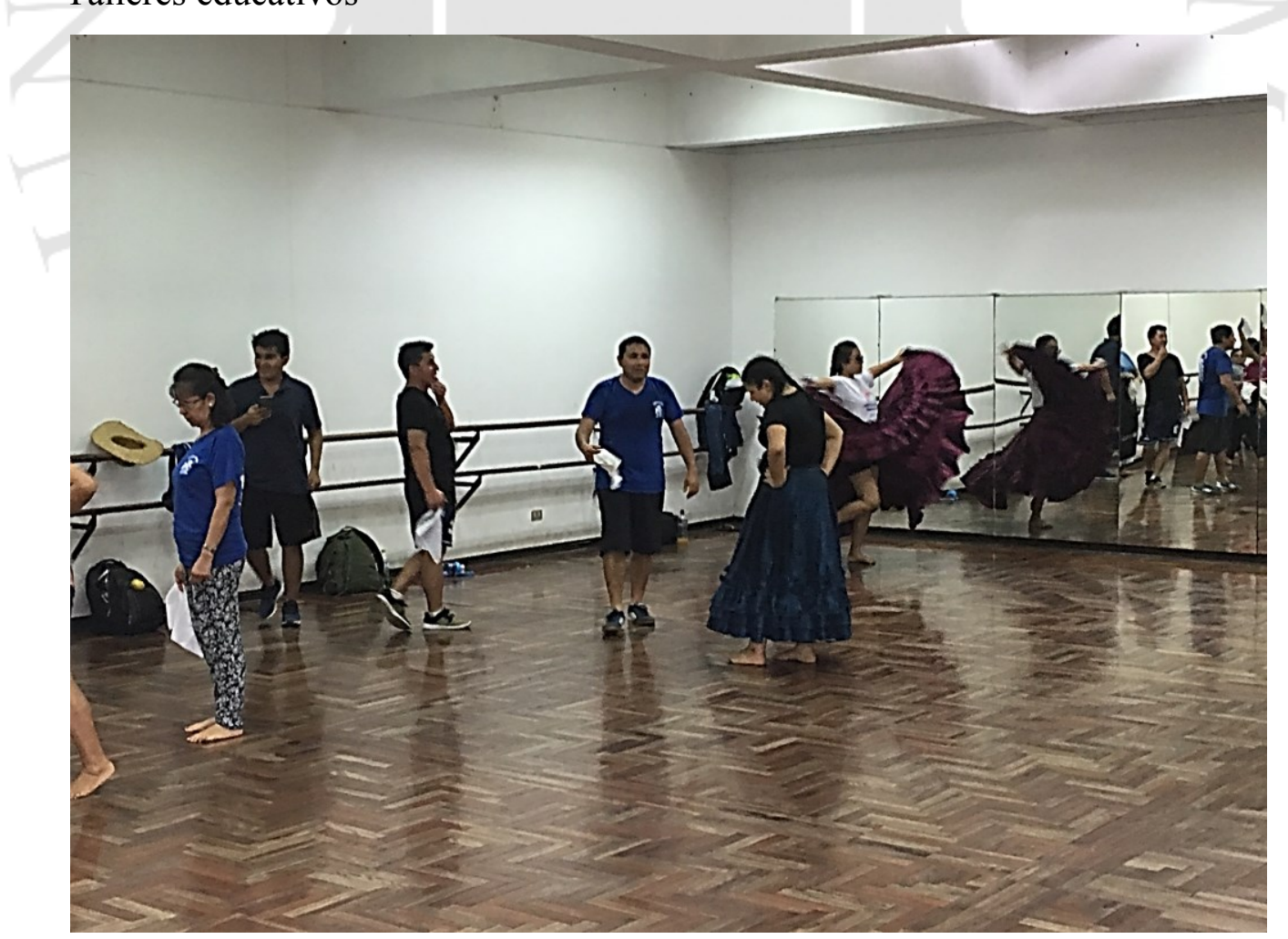

Nota: Taller de marinera, danza típica de la costa peruana.

Fuente: Elaboración propia, 2017 
Figura 5.10

Vista de anfiteatro

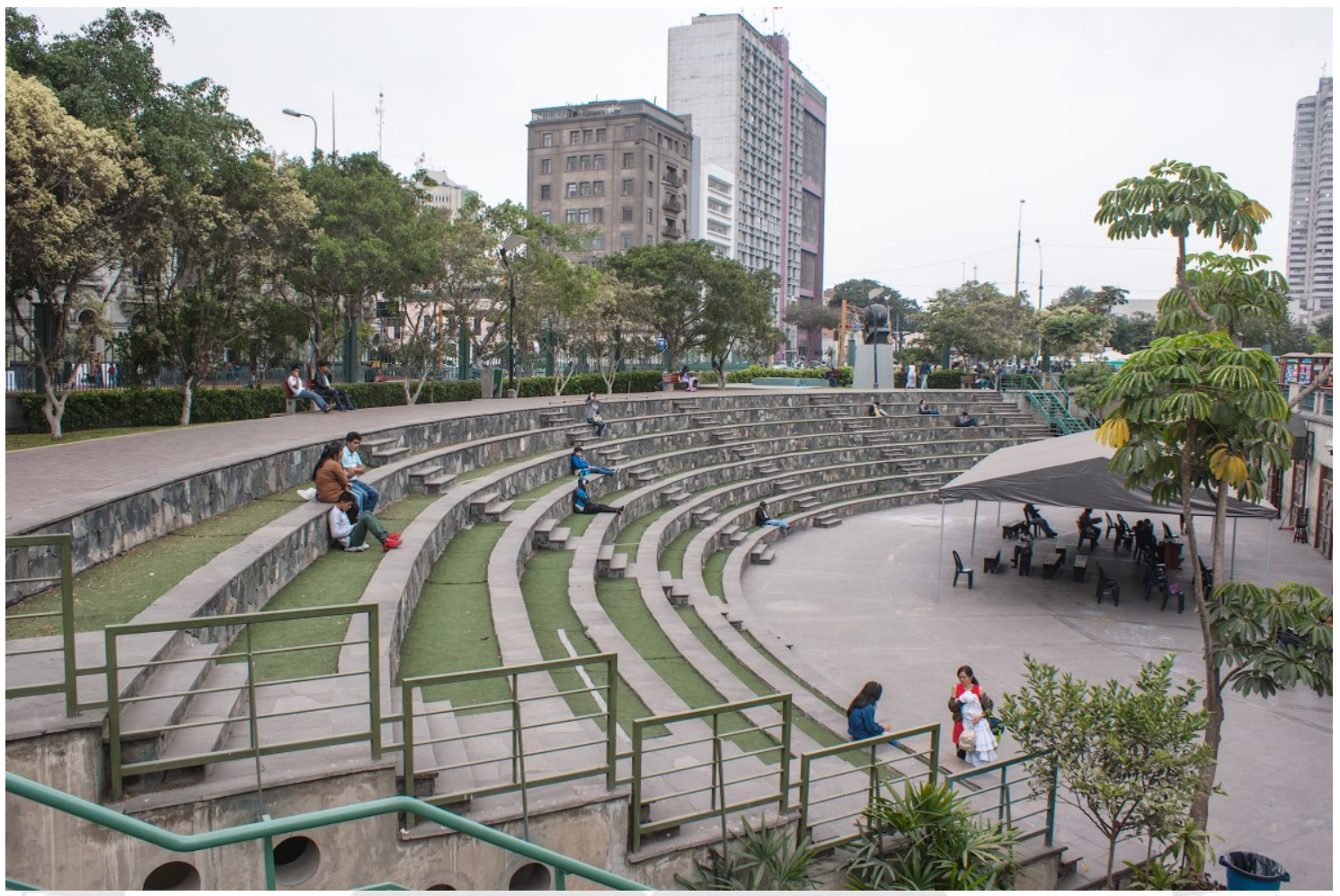

Fuente: Elaboración propia, 2017.

Figura 5.11

Vista del patio central

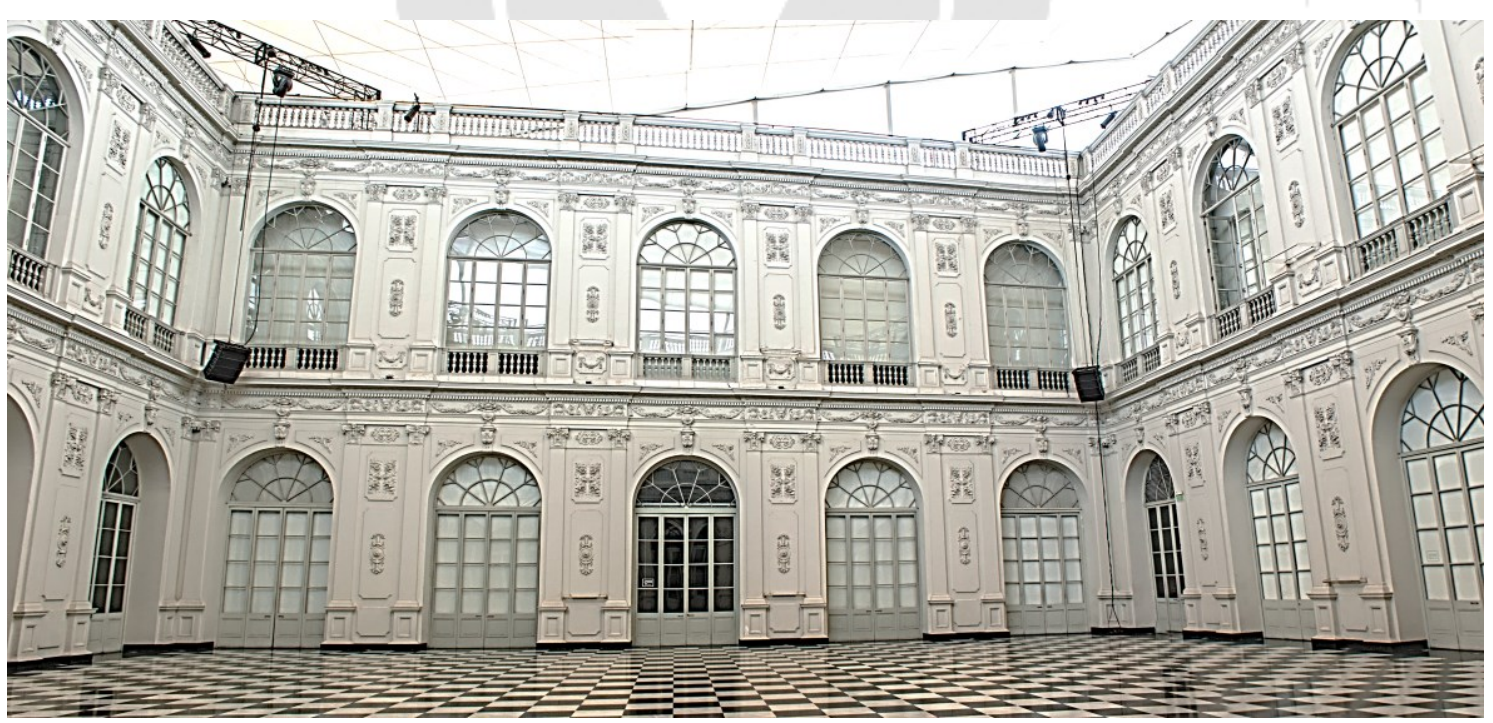

Fuente: Elaboración propia, 2017.

Dentro de la agenda cultural del museo, se encuentran: proyecciones de películas de temas referidos a la historia del Perú, conferencias y conciertos en el auditorio. Para el público infantil se realizan por las tardes los sábados de "Cuenta Cuentos". 
Por otro lado, el MALI cuenta con una Escuela Superior de Formación Artística (Escuela Superior MALI), destinada a formar, actualizar y capacitar profesionalmente a artistas, gestores culturales y profesores comprometidos con el desarrollo y mejoramiento de la educación, el arte y la cultura. (MALI, 2013)

\section{Forma}

Volumetría y emplazamiento

El museo es un volumen ortogonal de dos niveles. Tiene una proporción simétrica de sur a norte, así como de este a oeste: las fachadas se repiten en los lados que son opuestos.

El parque realza las características del inmueble, aislándolo del exterior a través de una plaza frente a la fachada sur que permite que el museo se vuelva un elemento de remate del recorrido del parque.

El contraste de dinámicas dentro y al exterior del parque es dramático. La Av. Paseo Colón y la Av. Wilson sufren serios problemas de contaminación visual, auditiva y de gases tóxicos; a esto se suma el deterioro natural del patrimonio edificado.

Figura 5.12

Fachada sur del MALI

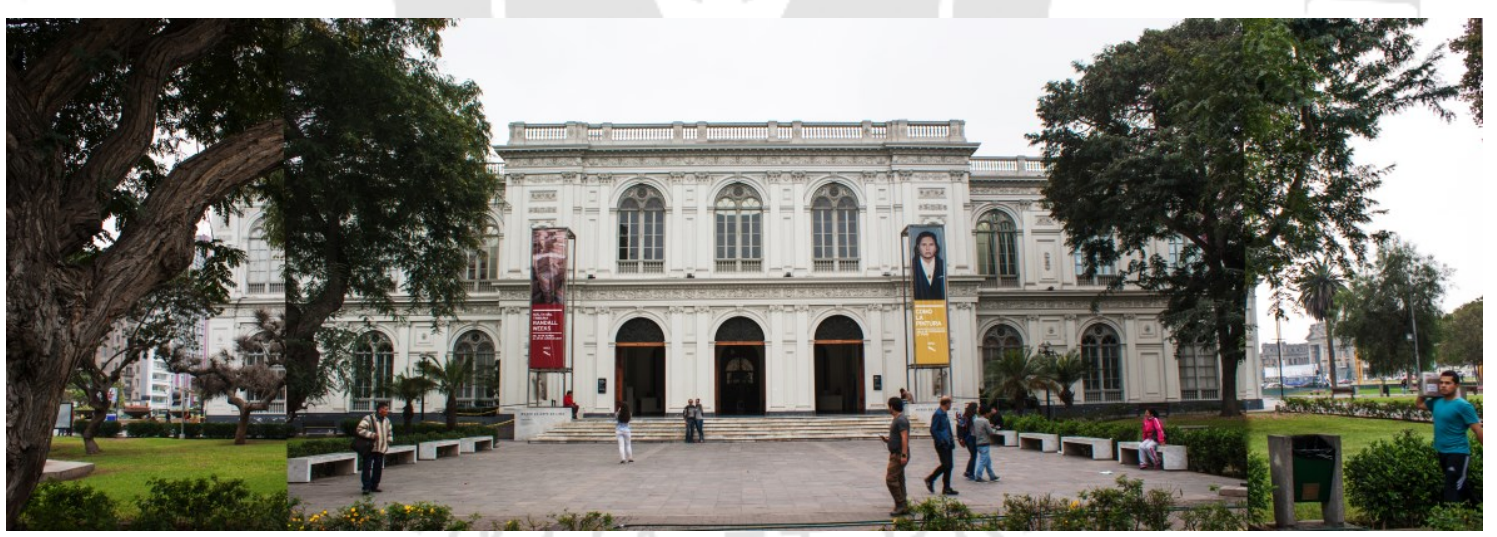

Nota: Fotomontaje elaborado a base de múltiples imágenes tomadas por el autor.

Fuente: Elaboración propia, 2017 
Figura 5.13

Fachada norte del MALI

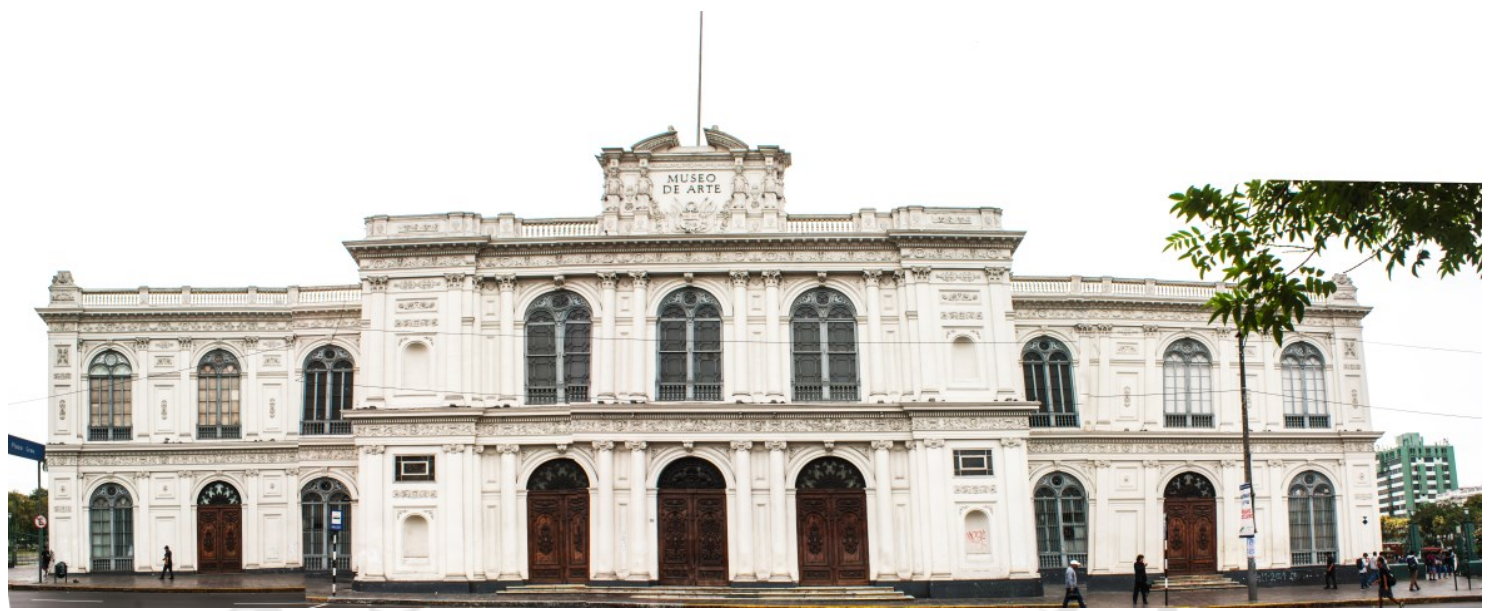

Nota: Fotomontaje elaborado a base de múltiples imágenes tomadas por el autor.

Fuente: Elaboración propia, 2017

El Palacio de la Exposición es un claro ejemplo de la arquitectura ecléctica limeña que combina el neorenacentista, estilos muy difundidos para la época. Se observa que las fachadas están compuestas por grandes ventanales de doble altura y dos accesos para el este y oeste; las fachadas sur y norte tienen sólo un acceso. El primer piso cuenta con un zócalo elevado, cuerpo de adobe en todo el perímetro con panelería de yeso y remate al finalizar las ventanas; el mismo ritmo se repite en el segundo piso. Ambas plantas tienen columnas metálicas a manera de planta libre.

Figura 5.14

Elevación sur y elevación oeste
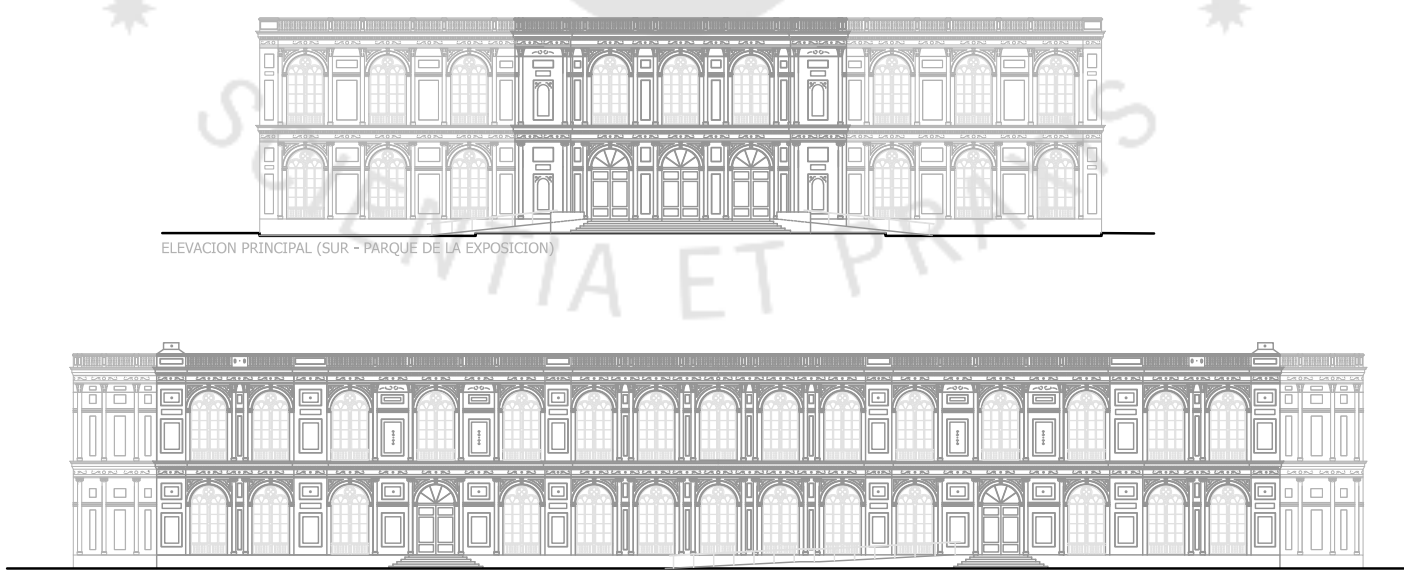

Fuente: Archivo MALI, 2015. 
Figura 5.15

Vista general del área a intervenir

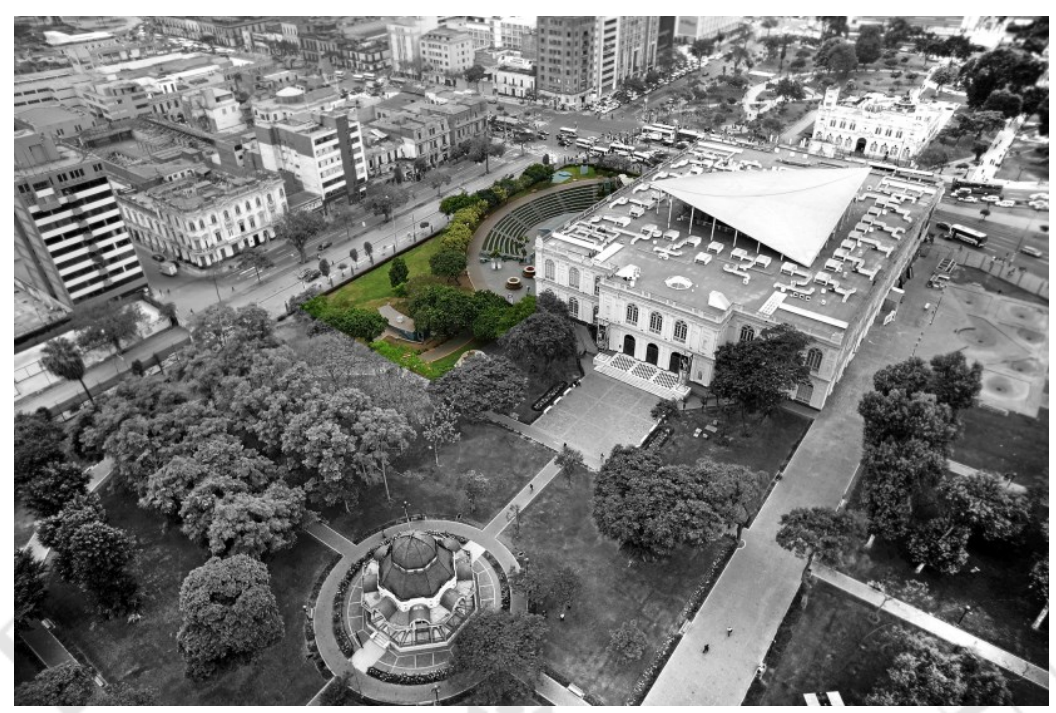

Fuente: Archivo MALI, 2015

El área a intervenir es de $3500 \mathrm{~m}^{2}$ (de la explanada oeste) y el área total construida de Patrimonio del Museo de Arte de Lima es $6000 \mathrm{~m}^{2}$. Por otro lado, el área total del Parque de la Exposición es de $30000 \mathrm{~m}^{2}$.

\section{Materialidad}

Materiales

- Columnas metálicas de $5 \mathrm{~m}$ de alto por $18 \mathrm{~cm}$ de diámetro.

Figura 5.16

Detalle de columna metálica
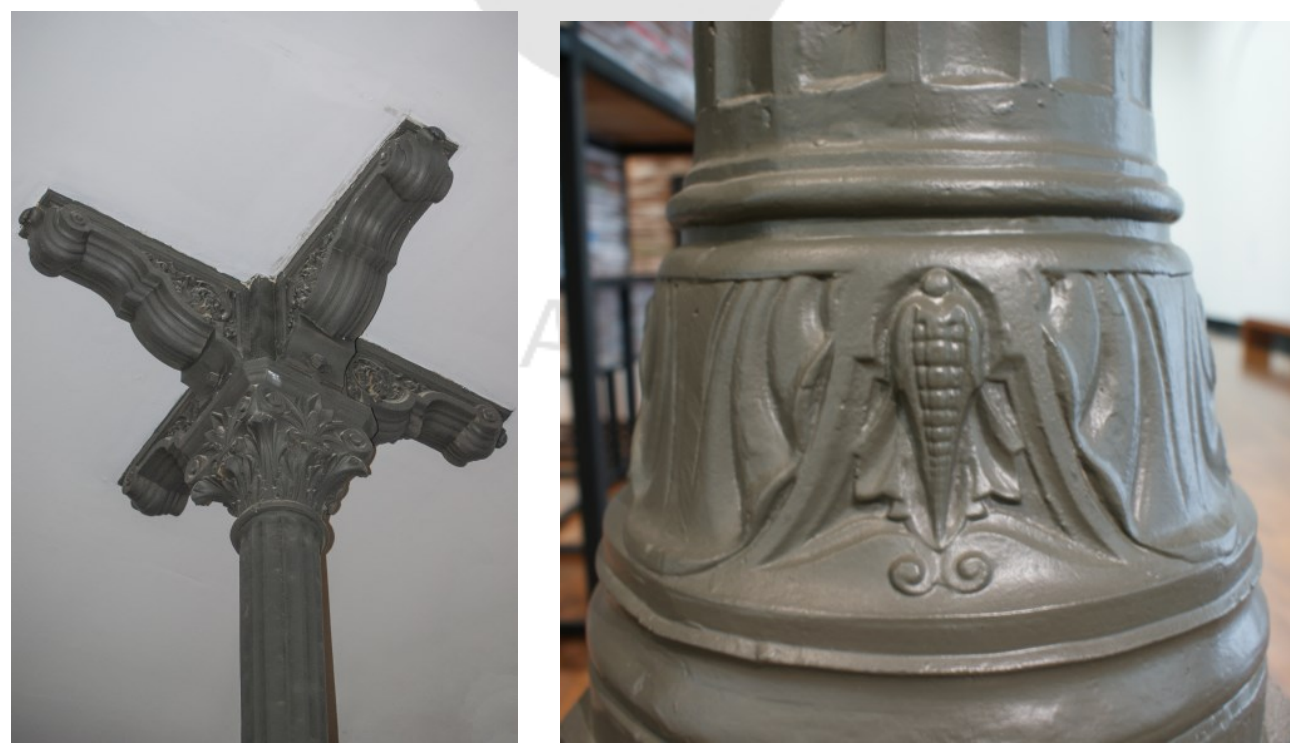

Nota: Capitel compuesto de columna metálica y base con motivos de maíz nativo.

Fuente: Elaboración propia, 2017 
- Muros de ladrillo pintado de blanco

- Pisos de cerámico, mármol negro y blanco, y madera parqué.

Figura 5.17

Tipos de pisos en el museo
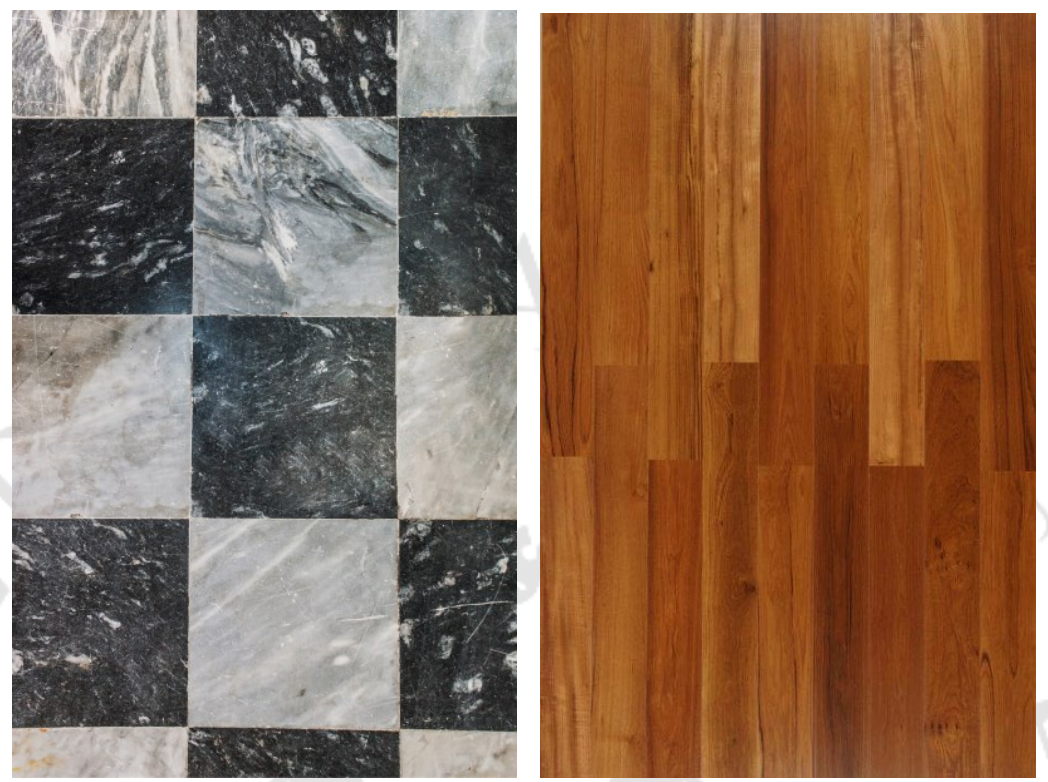

Nota: Piso en cuadricula de mármol de $30 \mathrm{~cm}$ por $30 \mathrm{~cm}$ para ambientes principales. Piso de madera de $7 \mathrm{~cm}$ por $40 \mathrm{~cm}$ para ambientes secundarios.

Fuente: Elaboración propia, 2017

\section{Usuario}

Edades: Predominan los visitantes de edad adulta.

Procedencia: Extranjeros y nacionales (escala sobre 10):

Tabla 5.1. Tipo de visitantes y cantidad

\begin{tabular}{|l|l|}
\hline \multicolumn{1}{|c|}{ Tipo de visitante } & \multicolumn{1}{c|}{ Grado de afluencia } \\
\hline Extranjero & 4 \\
\hline Local & 6 \\
\hline
\end{tabular}

Fuente: Instituto Nacional de Estadística e Informática, 2014. Indice temático: cultura. Recuperado de https://goo.gl/rQQ5c5

Tarifas (MALI, 2016. Visitanos):

Adultos desde S/ 6.00 a S/ 12.00 Estudiantes / mayores de 65 años / niños menores de 12 años $\mathrm{S} / 4.00$ Domingos populares $\mathrm{S} / 1.00$

Miembros del Programa Amigos del MALI (PAM) y alumnos MALI, Deutsche Bank Art Card, CINAM, Amigos do MAM - Río, Alumnos y docentes de la Universidad del 
Pacífico Ingreso gratuito.

Servicio de guía S/ 3.00 (por persona)

\section{Espacio}

Dimensiones, jerarquía e iluminación

Los halls del museo se imponen con su doble altura y amplitud, en ellos se realizan diversas exposiciones temporales, así como su alquiler junto con el patio para diferentes eventos externos al museo.

El patio por su ubicación central funciona como elemento organizador de las salas que lo circundan y otorga gran iluminación al local en general.

Respecto a la iluminación de las salas, es totalmente controlada a través de cerramientos en las ventanas y luz puntual artificial en el interior.

\section{Confort}

La sensación de confort dentro de las salas del museo es alta, sin embargo, la falta de lugares para sentarse y contemplar hace que el usuario no permanezca tanto tiempo como podría dentro de las exhibiciones.

Por otro lado, el patio central, a pesar de ser el ambiente integrador de todo el edificio, sirve principalmente como lugar de circulación durante el día; sólo existen actividades esporádicas, relacionadas con pequeños talleres para niños o publicidad de marcas. 


\subsection{Análisis de contexto}

\subsubsection{Vientos y asoleamiento}

\section{Lámina 5.1}

Vientos y asoleamiento
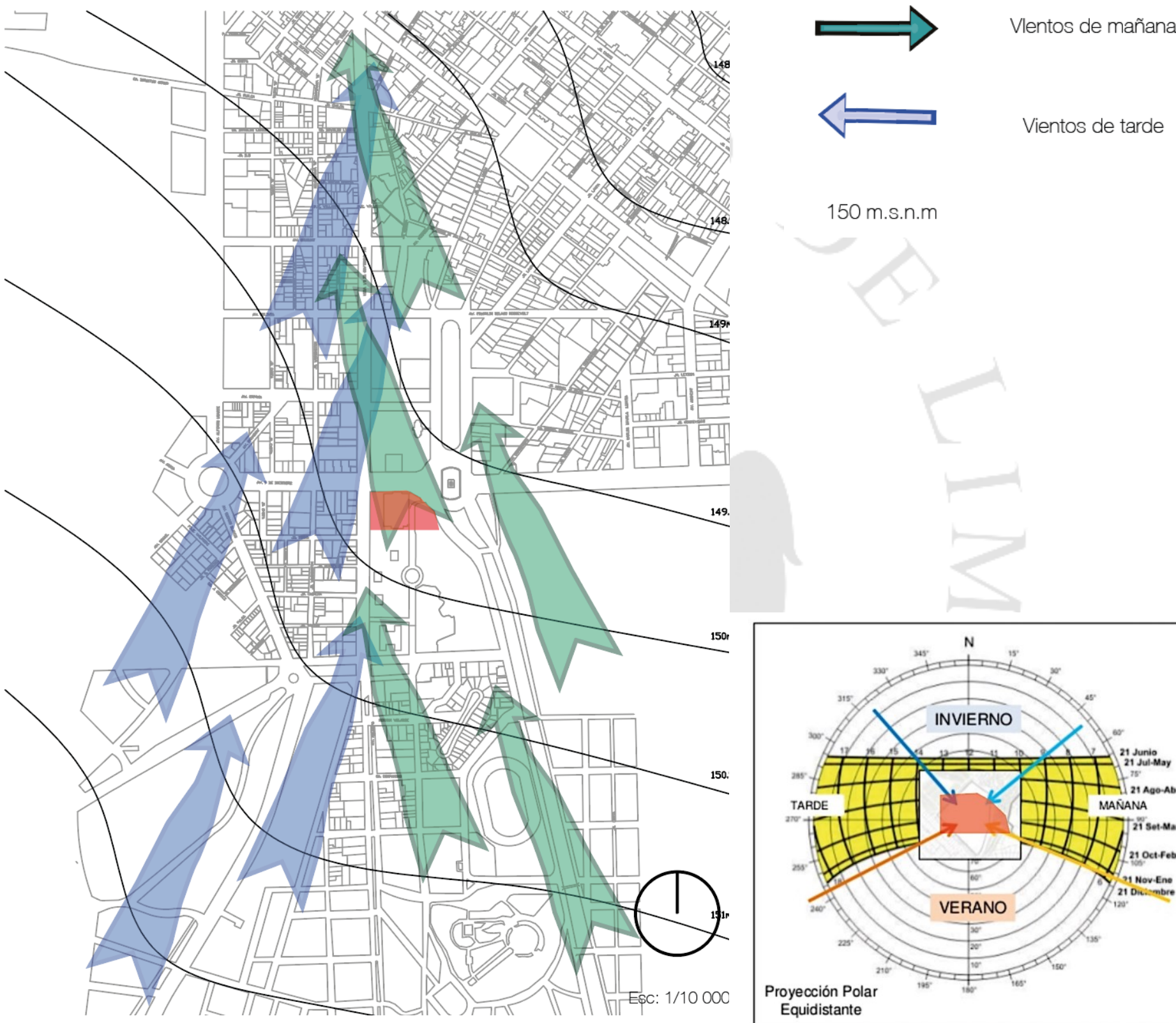

150 m.s.n.m

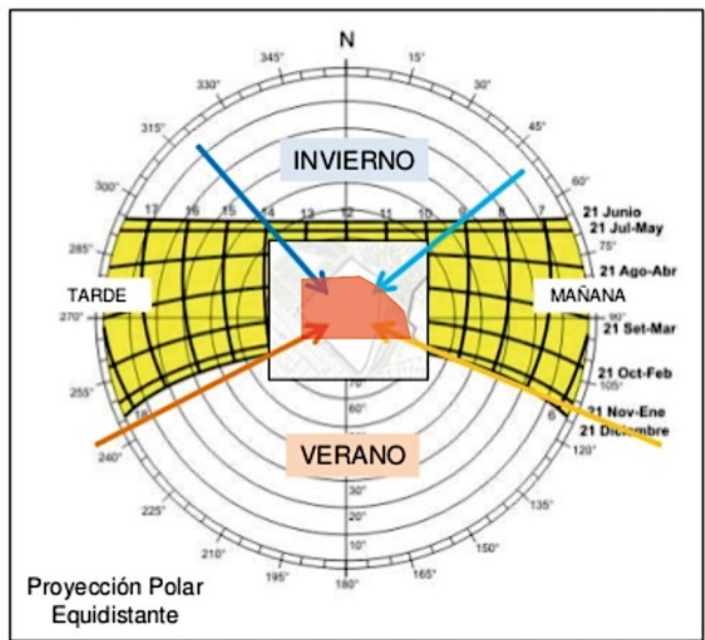

Nota: Los vientos vienen del sur. Las fachadas más prolongadas del MALI están en los lados este y oeste.

Fuente: Elaboración propia, 2015. 


\subsubsection{Sistema de áreas libres}

Lámina 5.2

Sistema de áreas libres

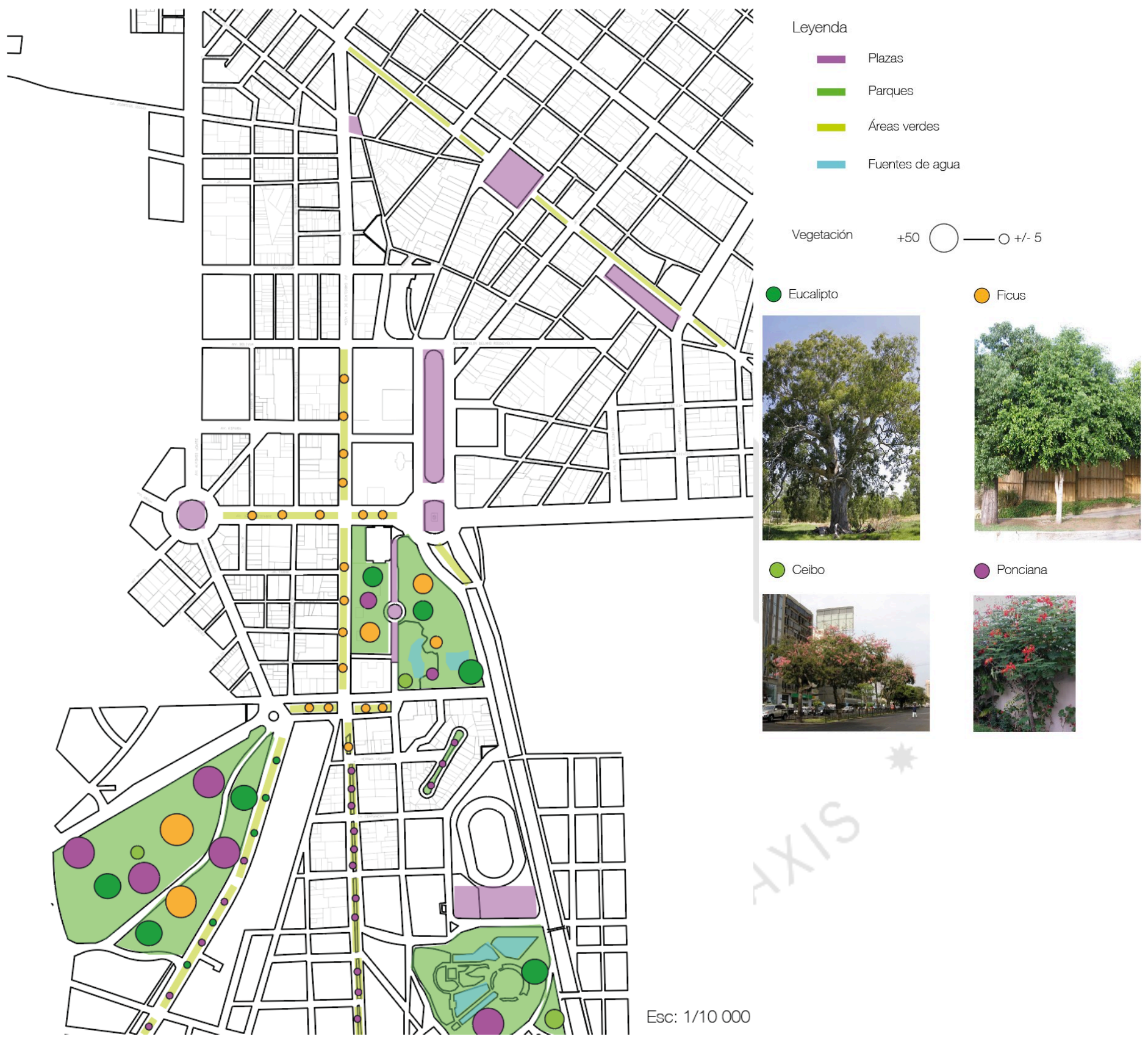

Nota: Árboles y arbustos nativos. Fuente de imágenes 1 a 4: Monografías, 2014. Árboles y arbustos de Lima. Recuperado de https://goo.gl/IMBqGR

Fuente: Elaboración propia, 2017. 


\subsubsection{Sistema de cuerpos edificados}

Lámina 5.3

Sistema de cuerpos edificados

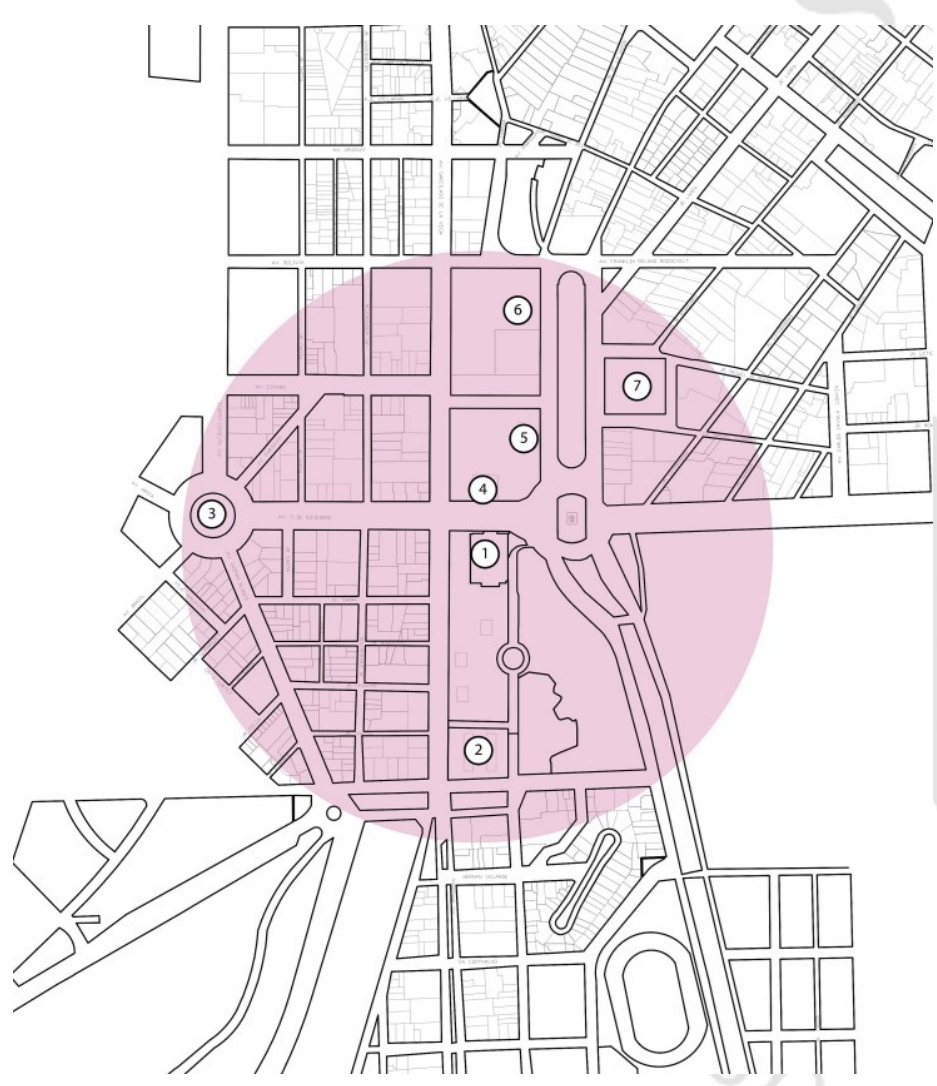

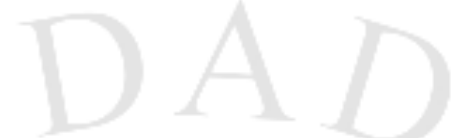

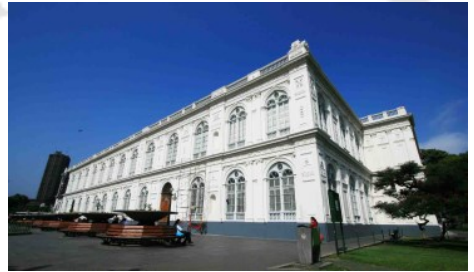

1. Museo de Arte de Lima - Estilo ecléctico

- Uso expositivo

- Importancia por su rol como primer

Palacio de la Exposición de 1876.

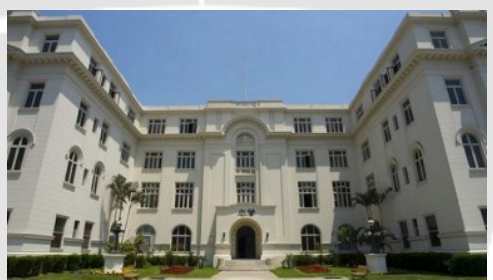

2. Museo Metropolitano

- Estilo neoclásico

- Uso expositivo

- Importancia por su rol como edificio

de gobierno desde 1929.

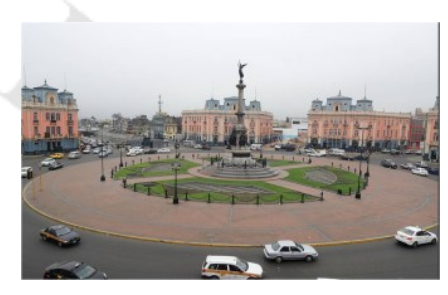

3. Plaza 2 de mayo

- Estilo académico francés

- Uso mixto

- Importancia por su aporte estético

y urbano a la ciudad en expansión a

principios de siglo XX.

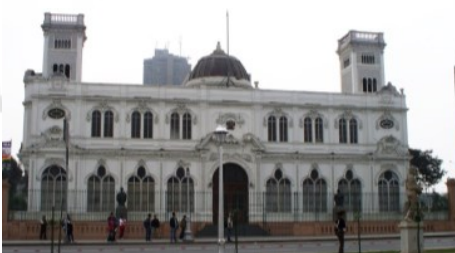

4. Museo Militar

- Estilo académico francés

- Uso expositivo

- Importancia por su rol como

aporte arquitectónico y de hito

en Paseo Colón.

Nota: Escala de plano 1/10 000. Vistas de edificios

Fuente de imágenes 1 a 7: Google Maps, 2013. Ubicaciones de monumentos en el Centro Histórico. Recuperado de https://goo.gl/jYDOvW

Fuente: Elaboración propia, 2015.

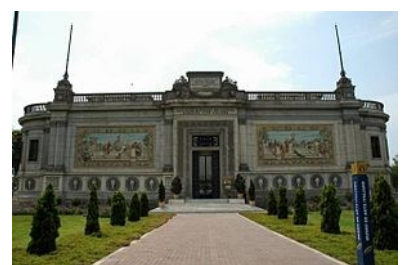

5. Museo Italiano

- Estilo neorenacentista

- Uso expositivo

- Importancia por ser símbolo de la legión italiana residente en el Perú y por su colección privada de obras de arte.

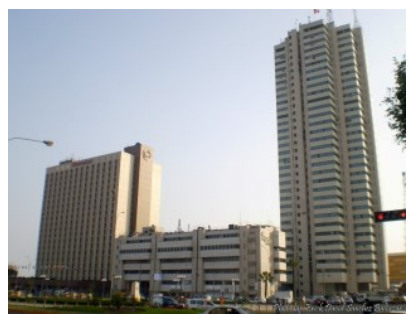

\section{Centro Cívico}

- Estilo brutalista moderno

- Uso mixto

- Importancia por ser símbolo

del brutalismo peruano.

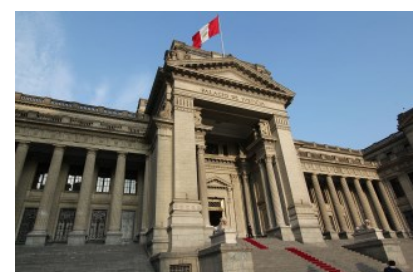

7. Palacio de Justicia

- Estilo neobarroco.

- Uso gubernamental

- Edificio construido inspirado

en el Palacio de Justicia

Bruselas. 


\subsubsection{Sistema de llenos y vacíos}

Lámina 5.4

Sistema de llenos y vacíos

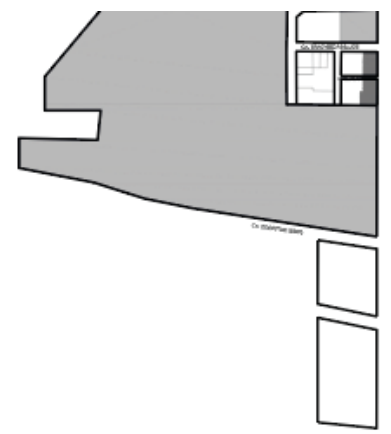

La zona analizada es exclusivamente el Cercado de Lima, los distritos colindantes aparecen en blanco.

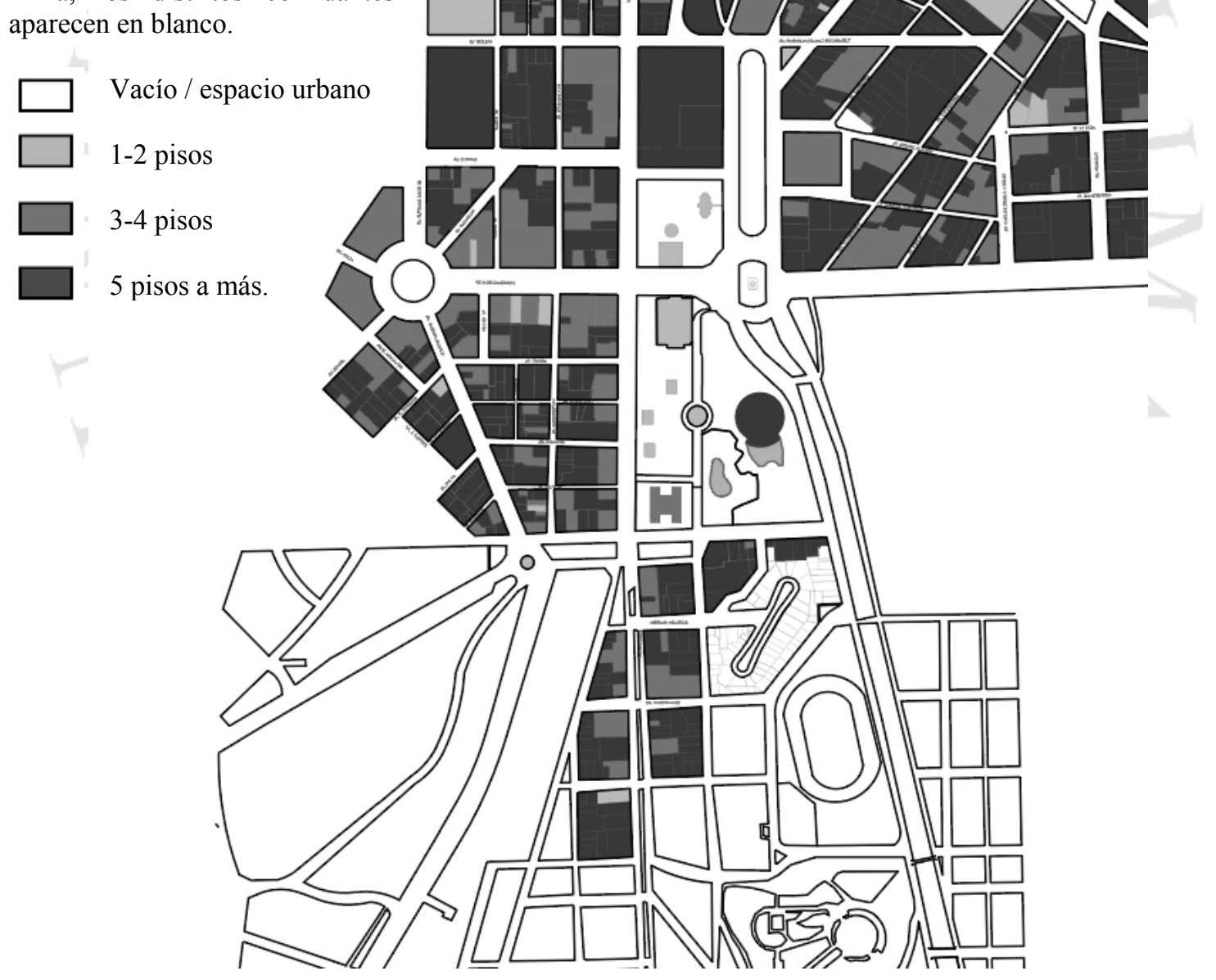

Fuente: Elaboración propia, 2015 


\subsubsection{Barrios y bordes}

Lámina 5.5

Barrios y bordes

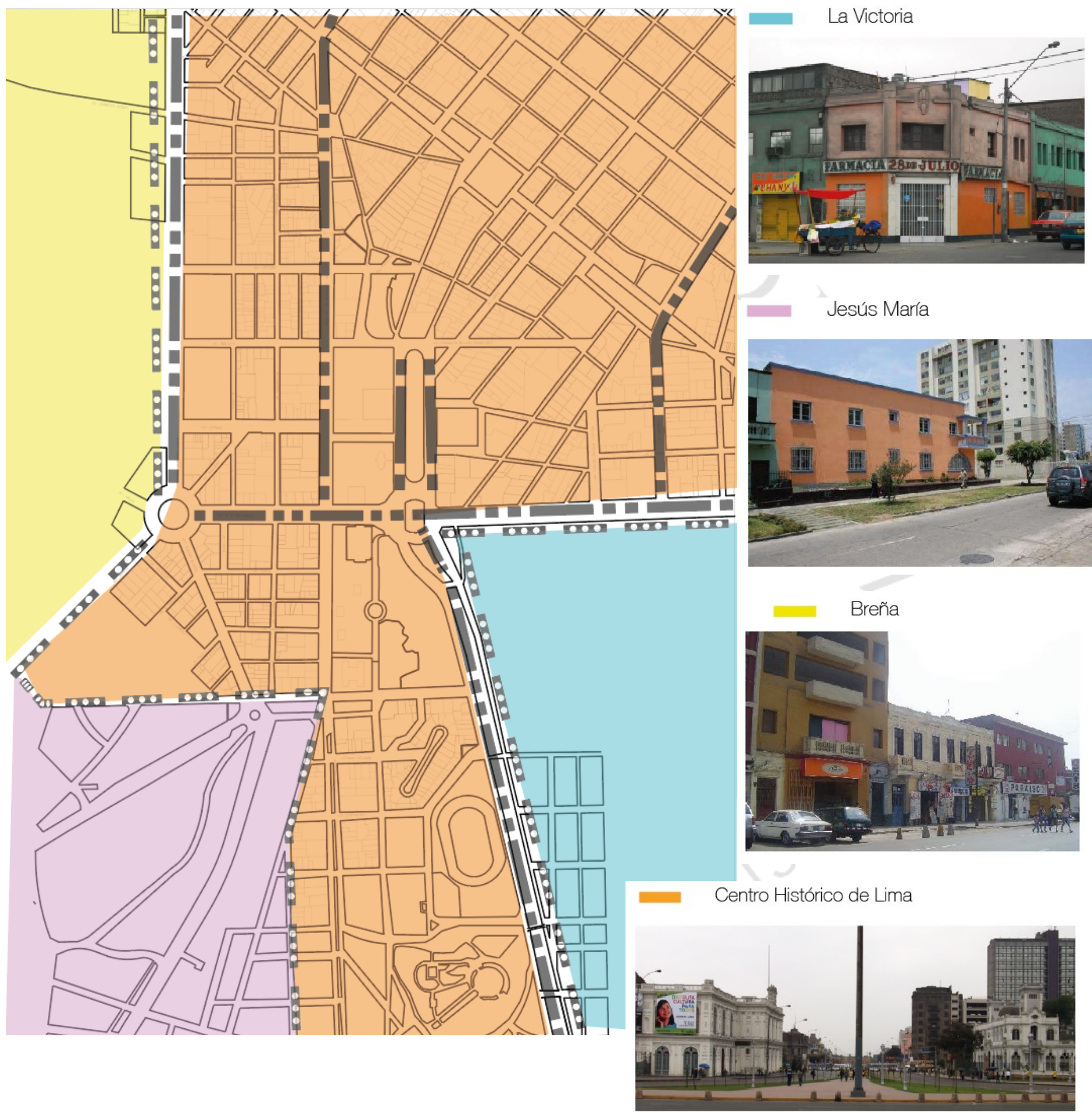

Vista de barrios.

Fuente de imágenes 1 a 4: Google Maps, 2015. Ubicaciones de barrios cirdundantes de Lince, Jesus María, Breña y el Centro Histórico. Recuperado de https://goo.gl/jYDOvW

Fuente: Elaboración propia, 2015 


\subsubsection{Hitos, nodos y sendas}

Lámina 5.6

Hitos, nodos y sendas

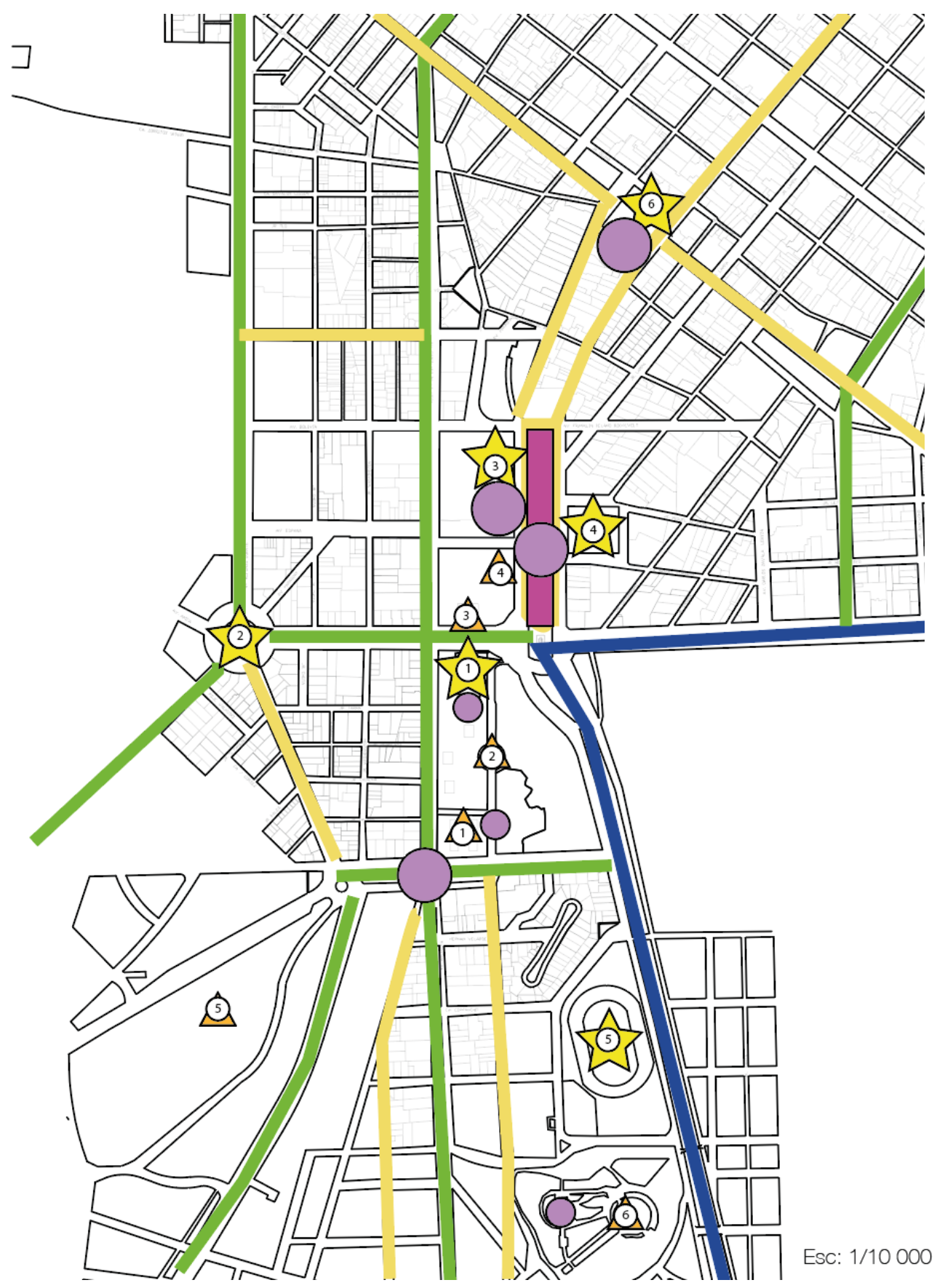

Leyenda

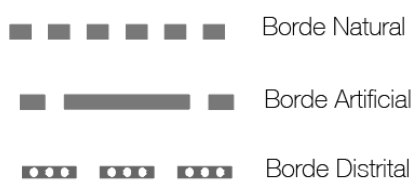

Leyenda

Via Expresa

Senda principal

Senda secundaria

$\{$ Hitos visuales metropolitanos

(1) Museo de Arte de Lima

(2) Plaza 2 de mayo

(3) Centro Cívico

(4) Palacio de Justicia

(5) Estadio nacional

(6) Plaza San Martín

$\triangle$ Hitos visuales locales

(1) Museo Metropolitano

(2) Fuente China

(3) Museo Militar

(4) Museo de Arte Italiano

(5) Campo de Marte

(6) Parque de la Reserva

Hitos espaciales

Estación central subterránea

Nodos principales

Nodos secundarios

Fuente: Elaboración propia, 2015 


\subsubsection{Flujos - Personas}

Lámina 5.7

Flujos - Personas

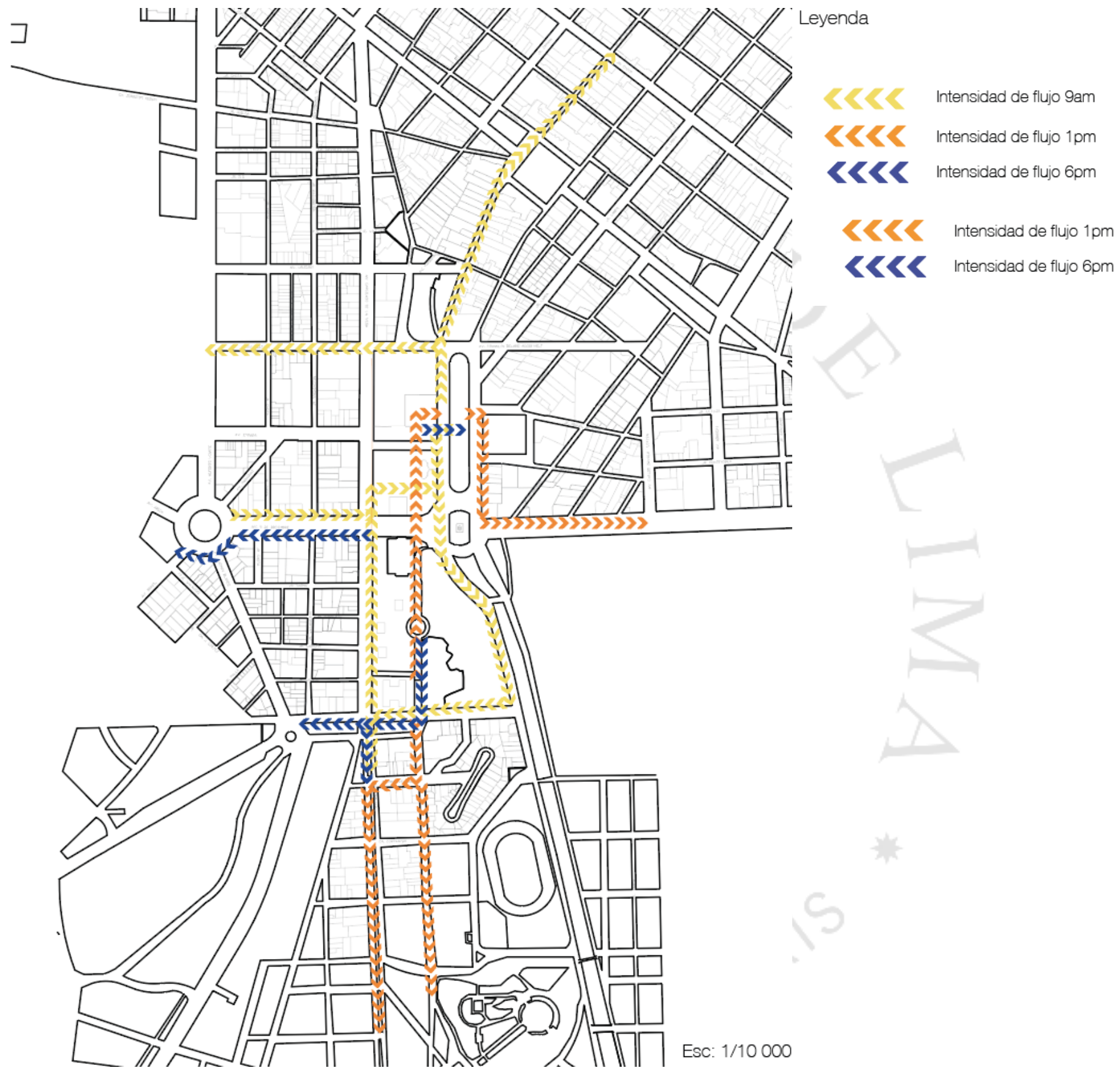

Fuente: Elaboración propia, 2015 


\subsubsection{Flujos - Vehiculos}

Lámina 5.8

Flujos - Vehículos

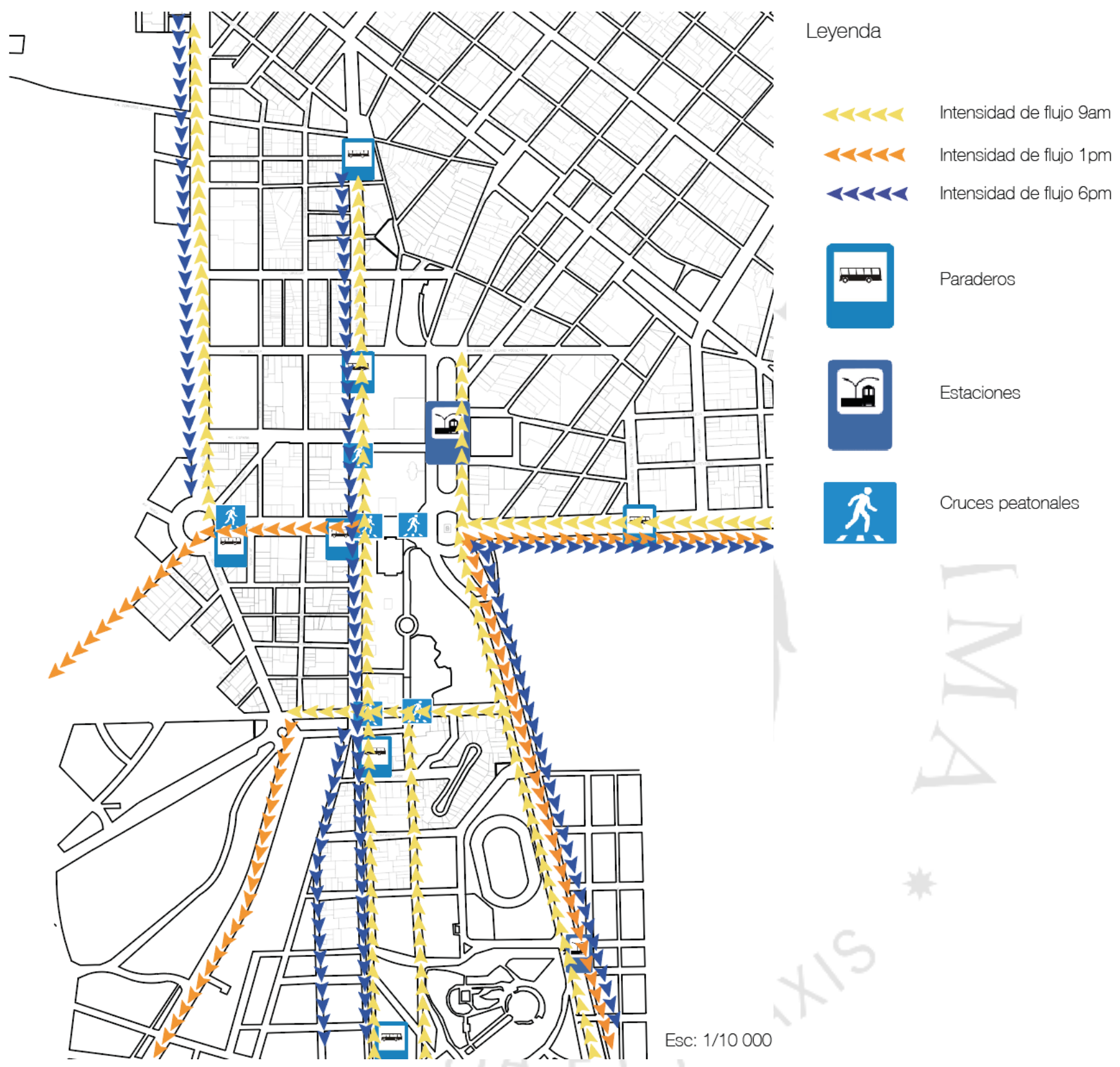

Fuente: Elaboración propia, 2015 


\subsubsection{Valor Monumental}

Lámina 5.9

Valor Monumental
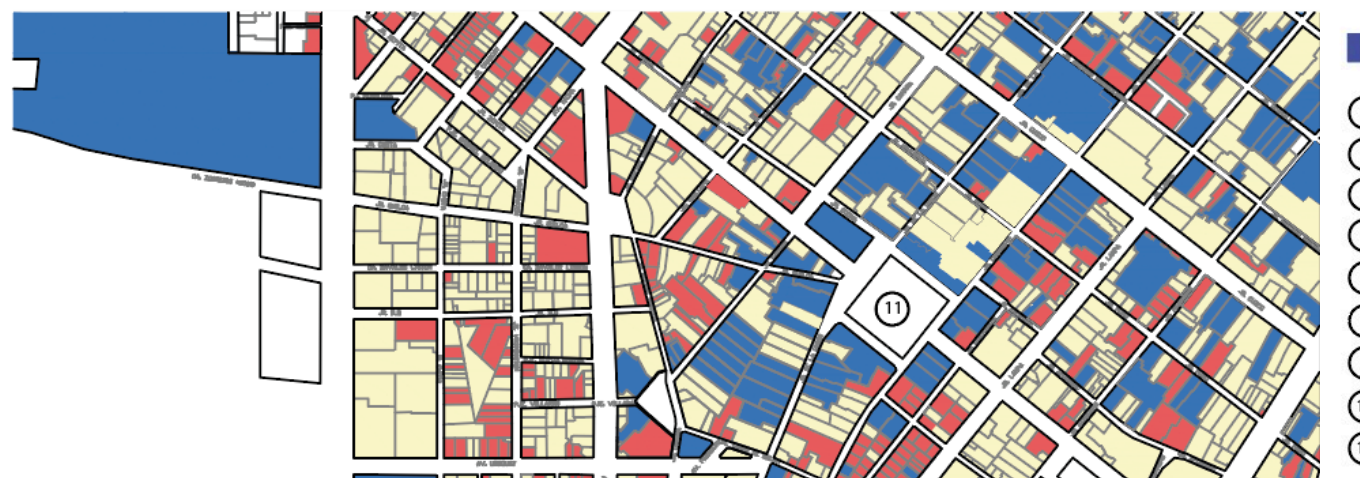

Monumento histórico

(1) Museo de Arte de Lima

(2) Fuente China

(3) Museo Metropolitano

(4) Museo Militar

(6) Museo de Arte Italiano

(7) Palacio de Justicia

(9) Edificio Rimac

(10) Plaza 2 de mayo

(11) Plaza San Martín
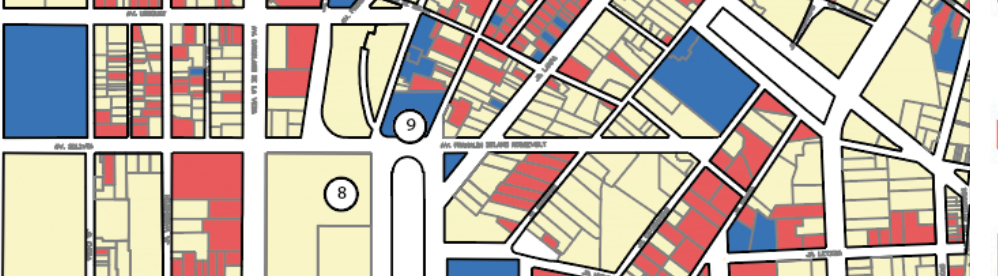

\section{Valor monumental \\ (5) Edificio Colón}
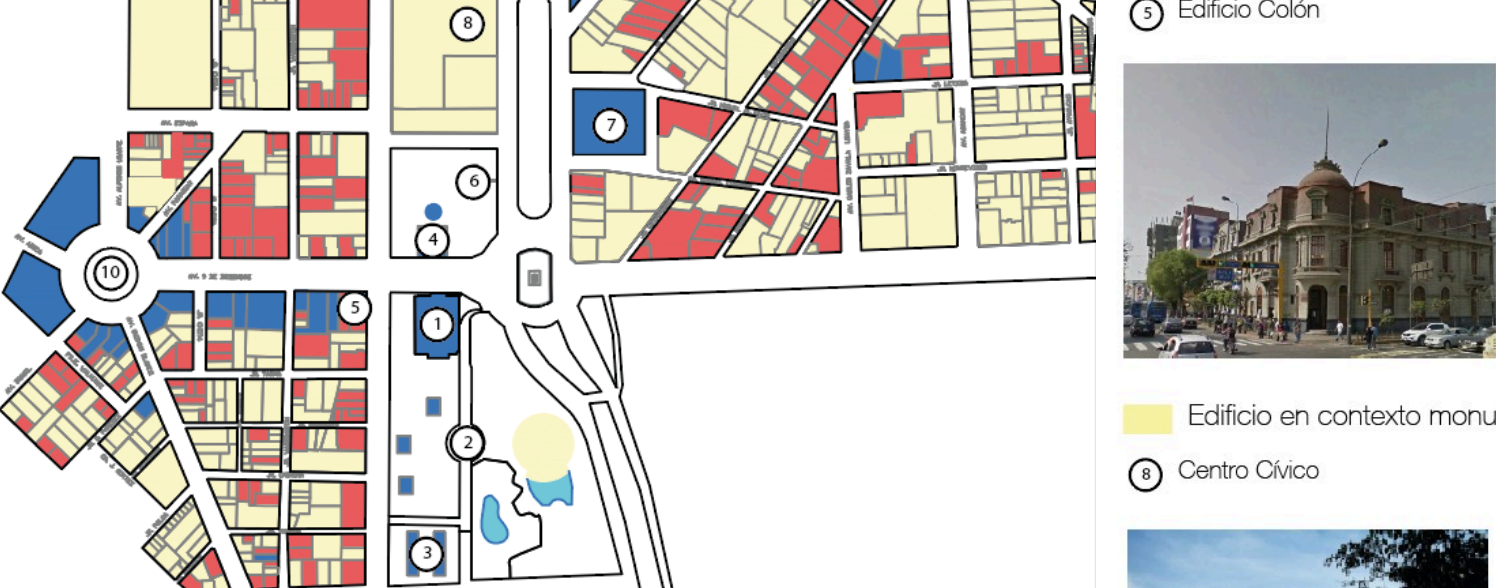
Edificio en contexto monumental
(8) Centro Cívico
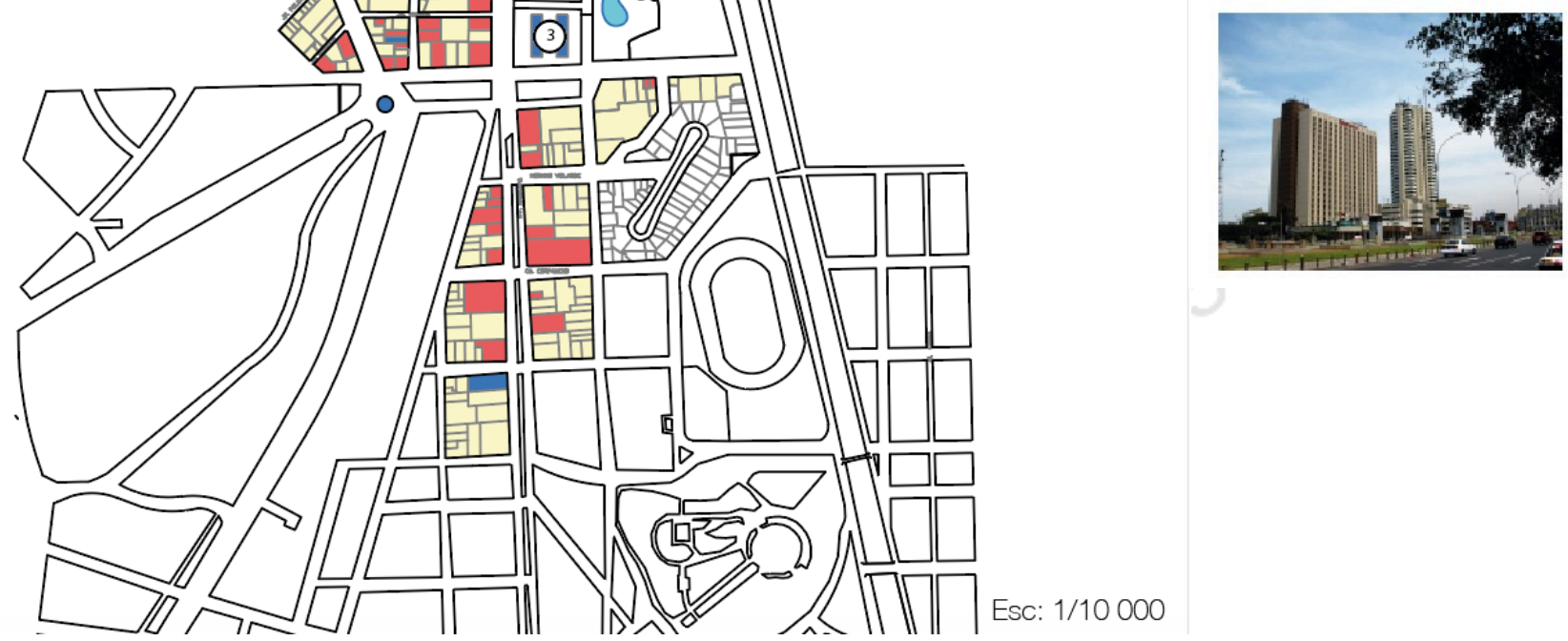

Vista de monumentos

Imágenes 1 y 2. Fuente: Google Maps, 2013. Ubicaciones de edificios de históricos, de valor monumental y en contexto monumental. Recuperado de https://goo.gl/jYDOvW

Fuente: Elaboración propia, 2015 


\subsubsection{Zonificación}

Lámina 5.10

Zonificación

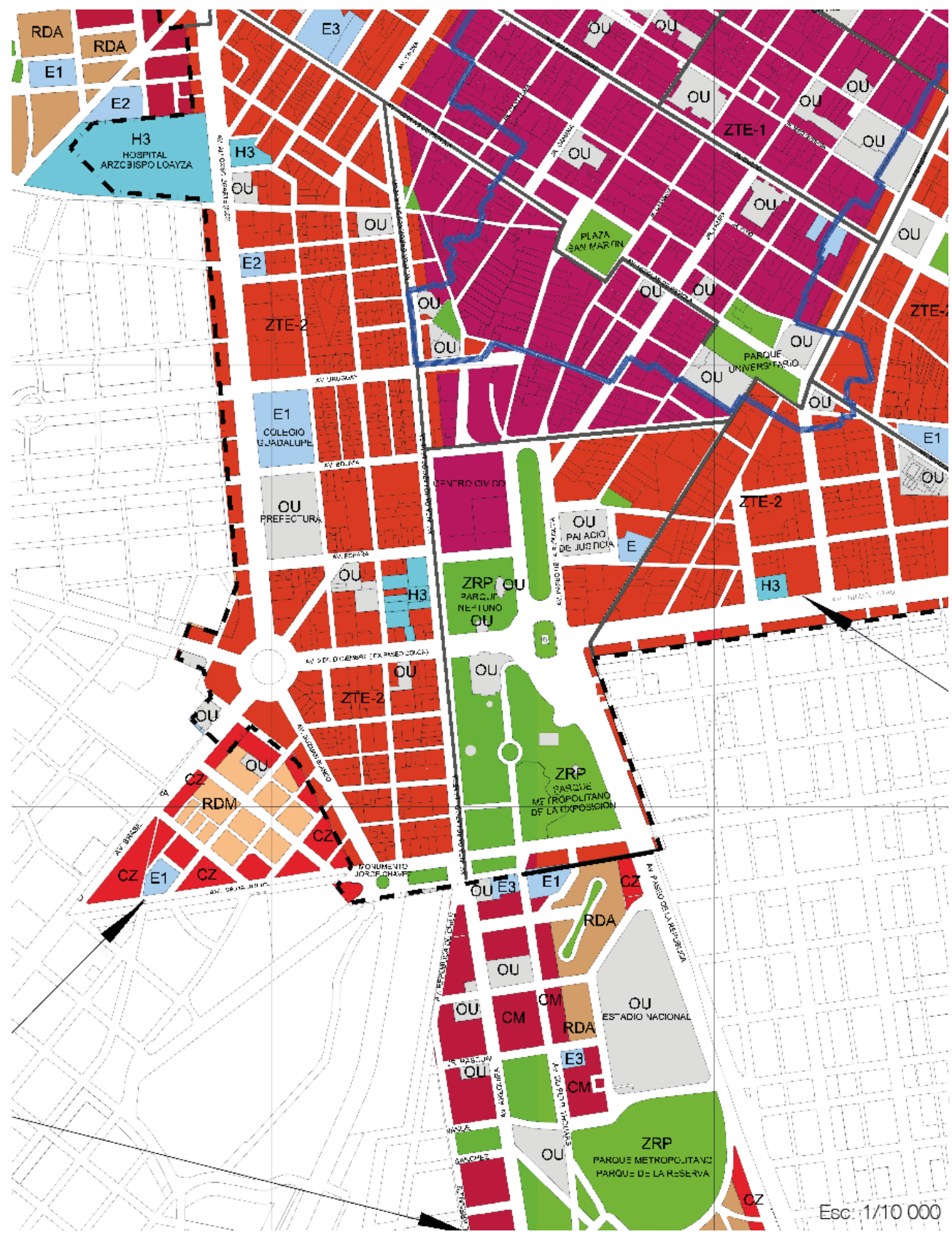

Leyenda

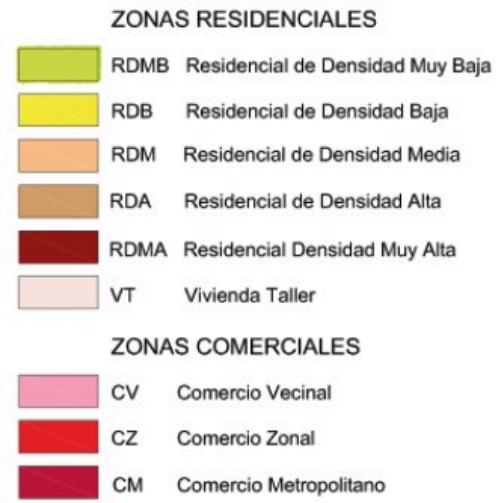

ZONAS INDUSTRIALES

I1 Industria Elemental y Complementaria

12 Industria Liviana

13 Gran Industria

$14 \quad$ Industria Pesada Básica

ZONAS DE EQUIPAMIENTO

E1 Educación Básica

E2 Educación Superior Tecnológica

E3 Educación Superior Universitaria

H2 Centro de Salud

H3 Hospital General

H4 Hospital Especializado

\section{CENTRO HISTORICO DE LIMA}

ZTE-1 Zona de Tratamiento Especial 1

ZTE-2 Zona de Tratameinto Especial 2

ZTE-3 Zona de Tratamiento Especial 3

ZRP Zona de Recreación Pública

OU Usos Especiales

ZRE Zona de Reglamentación Especial

fiphipi Reserva Intercambio Vial

- - - Limite de Area de Tratamiento Normativo Diferenciado

- Patrimonio Cultural de la Humanidad

Nota: El Museo de Arte de Lima es un edificio de Uso Especial, dentro de una zona de recreación pública, que a su vez está dentro de una zona de tratamiento especial.

Fuente: Instituto Metropolitano para la Planificación, 2014. Planos de zonificación de Lima Metropolitana y Ordenanza de Aprobación. Recuperado de https://goo.gl/24dVNA 


\subsubsection{Parámetros urbanísticos}

Lámina 5.11

Parámetros urbanísticos

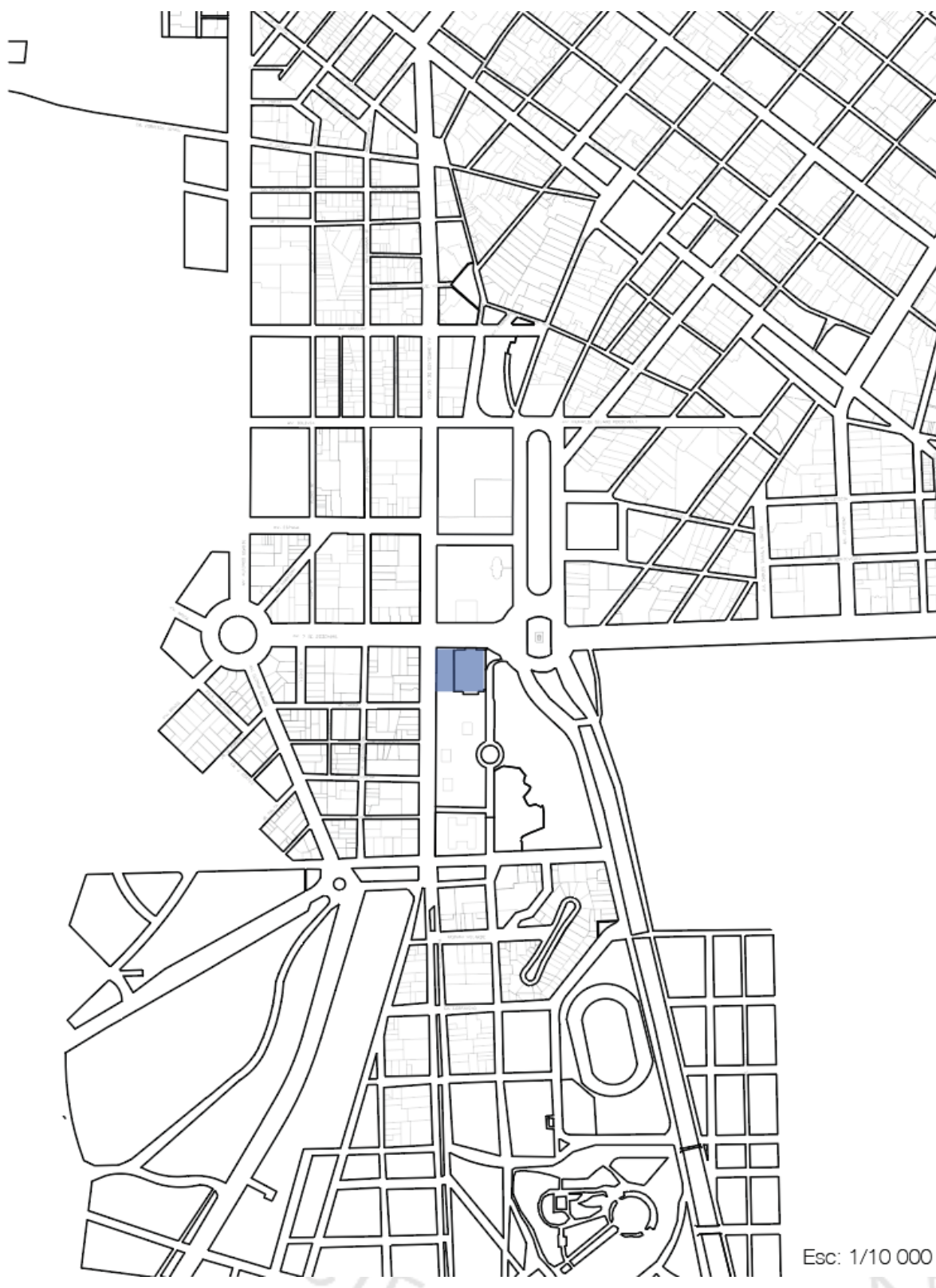

Parámetros generales:

Ubicación: Paseo Colón 125,

Cercado de Lima

Área de lote (Museo): 6000m2

Área de lote (Plaza): 2800m2

Área construida: $12000 \mathrm{~m} 2$

Altura de precio: $15.5 \mathrm{~m}$

Zonificación: Otros usos

Altura permitida: según contexto

Área libre: según contexto

Según la ordenanza MML No 893:

Artículo 4.- Zona de

Recreación Pública (ZRP)

Disponer que las áreas calificadas como Zonas de Recreación Pública (ZRP) (...) dentro del Centro Histórico de Lima, conforman una unidad urbano paisajista y constituyen patrimonio recreativo, cultural y ambiental a ordenarse $\mathrm{y}$ acondicionarse mediante proyectos específicos, que consideren la consolidación de malecones, campos deportivos e infraestructura turística $\mathrm{y}$ cultural.

Artículo 6 Establecer que toda gestión que se realice ante la Municipalidad Metropolitana de Lima, en materia de obra pública o privada de edificación o demolición, que recaiga sobre bienes inmuebles, localizados en el territorio del Cercado de Lima, que hayan sido expresamente declarados Monumentos Históricos y/o tengan valor monumental y que constituyan Patrimonio Cultural de la Nación, se solicite previamente la opinión técnica del Instituto Nacional de Cultura.

Según la ordenanza MML No 946:

Establecer que para el caso de los predios colindantes con las fachadas a conservarse que han sido identificadas por el Instituto Nacional de Cultura y a las cuales se refiere el Artículo Tercero de la Resolución Directoral Nacional No 055-INC de fecha 27 de enero de 2004 y Plano DM-050-2002-INC; las nuevas edificaciones deberán considerar una integración arquitectónica y generar una adecuada armonía en el entorno urbano.

Fuente: Elaboración propia, 2015 


\subsubsection{Percepción}

Lámina 5.12

Percepción de terreno para ampliación
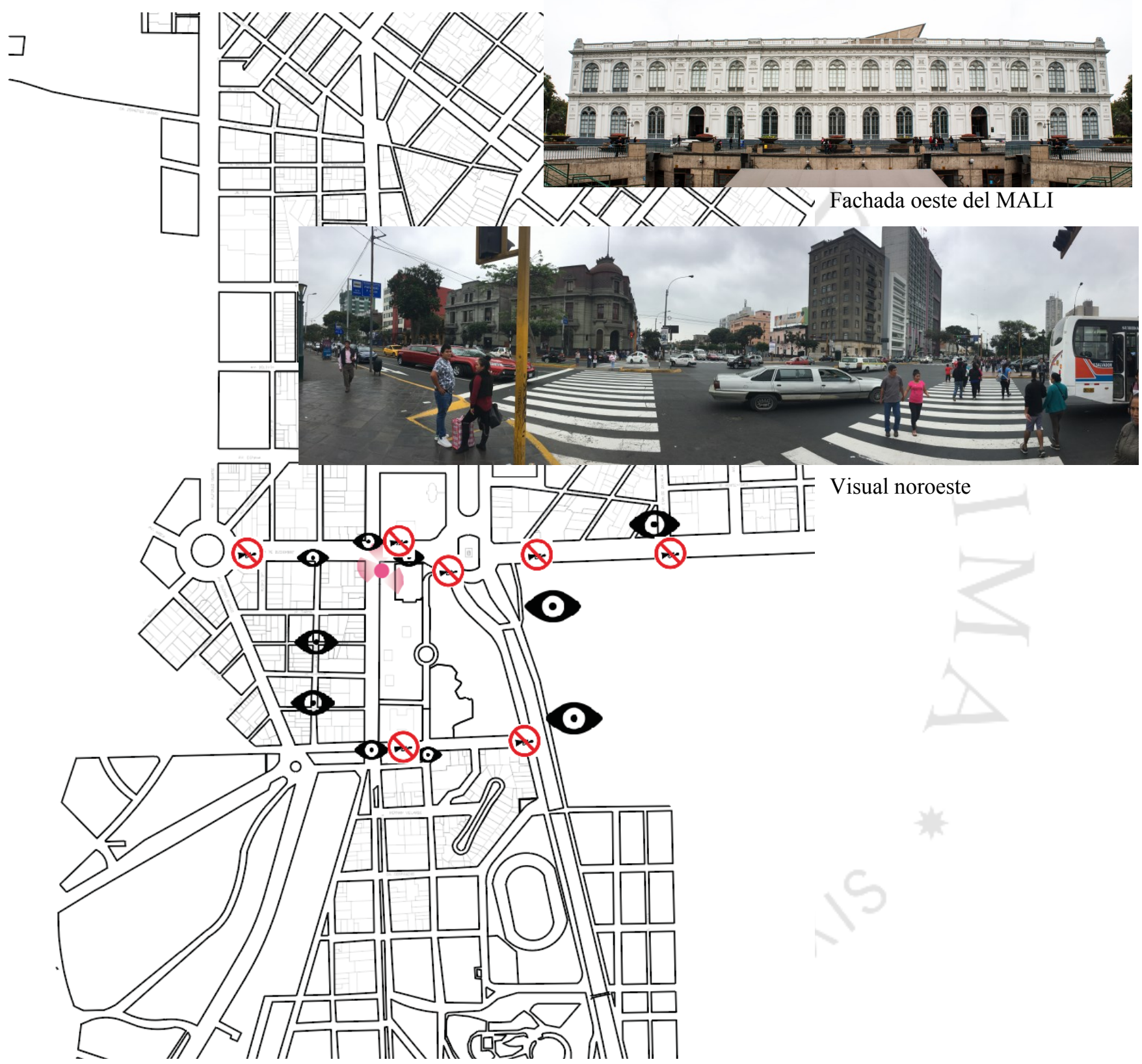

\footnotetext{
(-) Contaminación visual: avisos informales, edificios en mal estado, tráfico, polución Esc: 1/10 000

Due Contaminación auditiva: ruido de autos, comercio informal
}

Nota: Vistas desde la esquina noroeste del Parque de la Exposición

Fuente: Elaboración propia, 2017 


\subsubsection{Levantamiento fotográfico}

Lámina 5.13

Levantamiento fotográfico

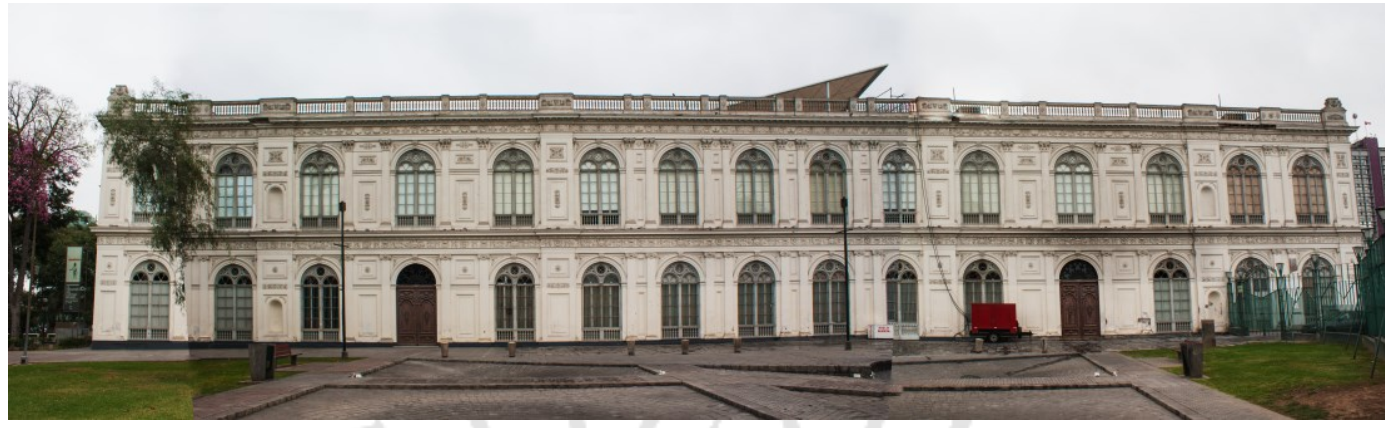

Fachada este
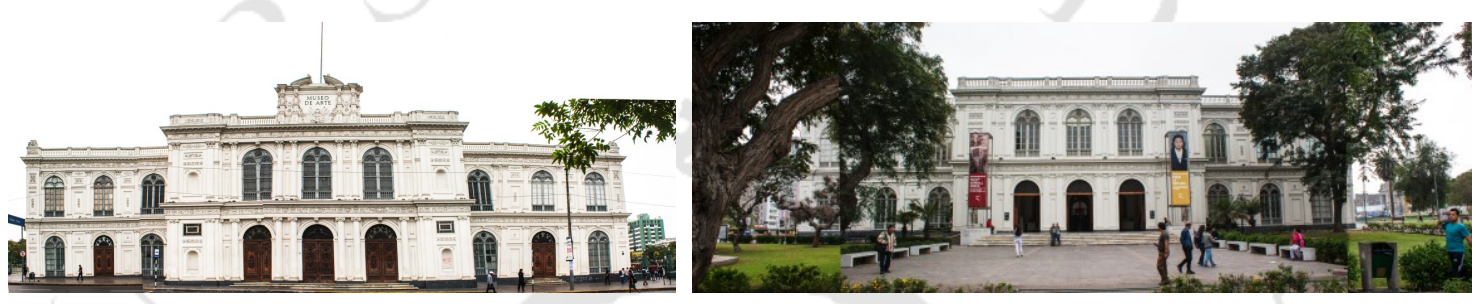

Fachada norte y sur

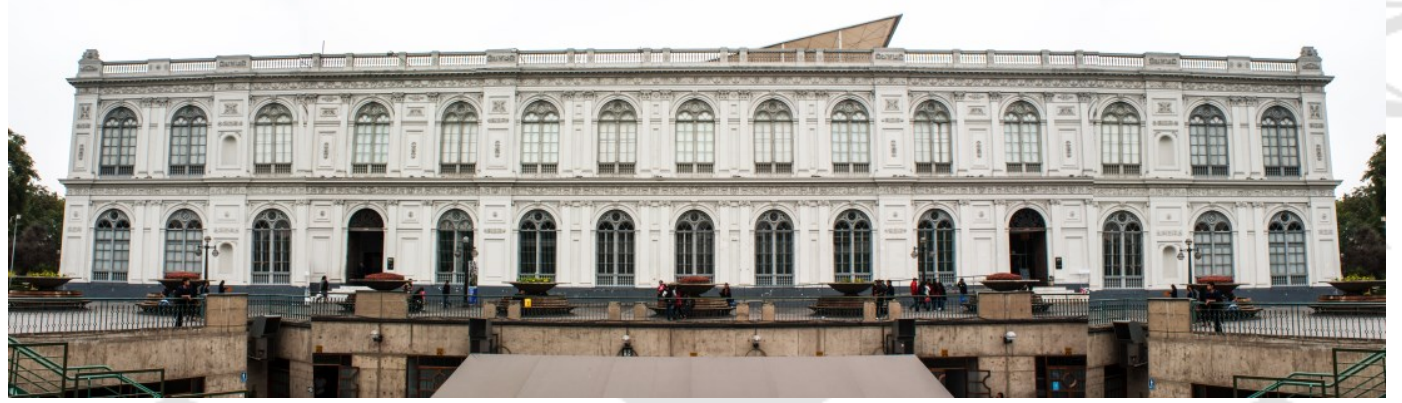

Fachada oeste

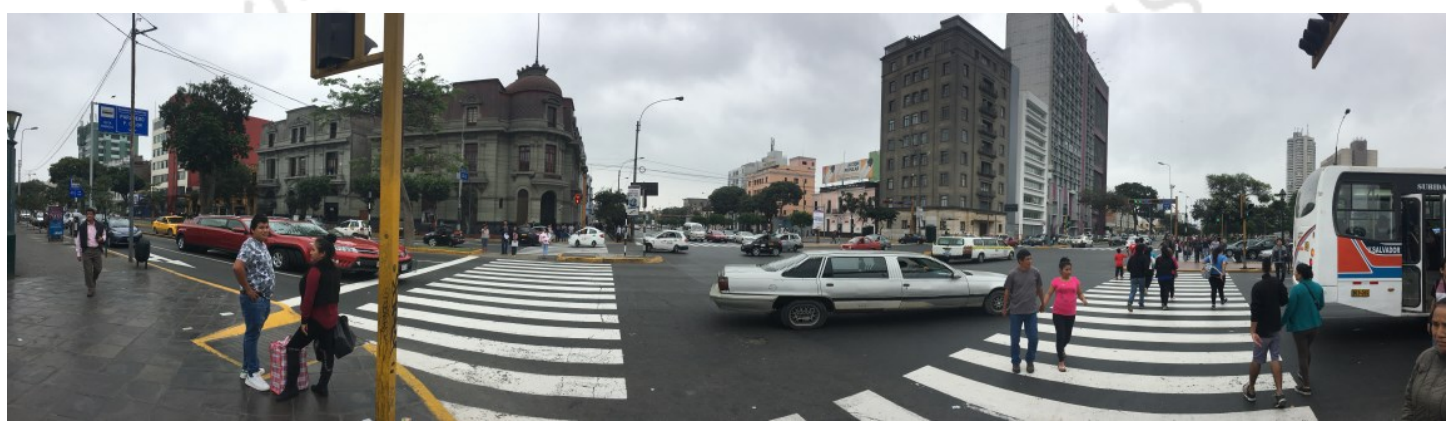

Vecinos inmediatos

Nota: Fotomontaje elaborado a base de múltiples imágenes tomadas por el autor en la zona a intervenir.

Fuente: Elaboración propia, 2017. 


\subsubsection{Potencialidades y limitaciones}

\section{Lámina 5.14}

Potencialidades y limitaciones
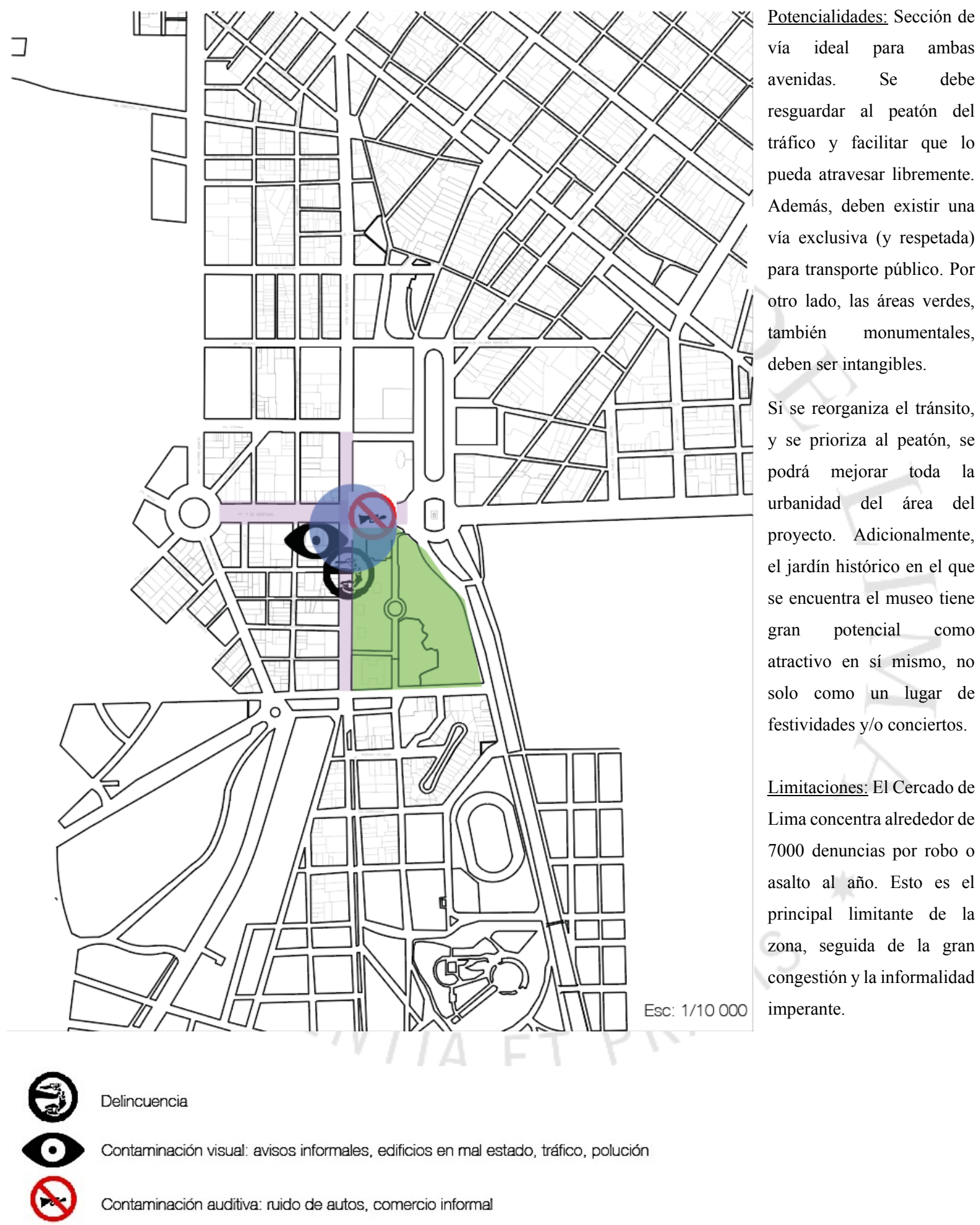

Fuente: Elaboración propia, 2015 


\subsection{Conclusiones parciales}

Luego del análisis del contexto monumental del Parque de la Exposición, y del edificio del Museo de Arte de Lima, podemos concluir los siguientes puntos:

En primer lugar, el Parque de la Exposición ha sufrido números cambios y mutilaciones en el tiempo, lo que debe llamar la atención sobre su recuperación y su devolución e integración a la ciudad. El proyecto de intervención y ampliación del Museo de Arte de Lima debe incluir un diseño que contemple también su relación con el parque.

En segundo lugar, existe una normativa nacional que debe respetarse y considerarse a la hora de hacer las modificaciones. Además, existen lineamientos generales de organismos internacionales que también deben tomarse en cuenta.

Entonces, luego de 20 años de haber empezado un proceso de remodelación (Museo de Arte de Lima, 2016), y considerando la intención del Museo de Arte de Lima de utilizar el espacio que le pertenece que da a la fachada oeste del edificio para su ampliación, se deben tomar en cuenta las siguientes consideraciones respecto al programa arquitectónico:

- La plaza donde se realizará la ampliación en forma de media luna hundida está siendo subutilizada; su intervención debe aumentar la capacidad expositiva y de talleres al menos al doble y poner en valor el contexto en el que se encuentra dentro del Parque de la Exposición.

- El edificio que es considerado Patrimonio Histórico de la Nación debe ser respetado en su totalidad, ya que además está siendo restaurado durante está gestión.

- Pese a esto, debe existir una conexión y un diálogo entre el edificio y la propuesta subterránea; puede ser física o visual.

- La principal función de este nuevo edificio será exhibir arte contemporáneo y albergar aulas (para aprox. 200 personas), esto debe ser reflejado en la forma y los materiales elegidos.

- Este edificio debe tener un impacto en el entorno inmediato, su función "educativa" no se limitará a su interior; debe de alguna manera producir algún tipo de sensación relacionada a la identidad de la ciudad al ser visto. 
- Por un tema de jerarquía y equilibrio con respecto al Parque de la Exposición, la intervención no debe ganar protagonismo al palacio.

- Parte de este edificio debe funcionar como espacio público, ya que, en esencia, se encuentra en la calle y debe invitar a los ciudadanos a entrar y ser visitado.

- El concepto arquitectónico debe evidenciar una reflexión sobre la cultura en la ciudad de Lima. Los materiales y estructura deben reflejar su propósito dentro lo posible.

\section{Posibles nuevos usos:}

El MALI en la actualidad tiene problemas tratando de ubicar el área administrativa ya que se encuentra en distintos ambientes en la sede principal. Además, los talleres ya no se dan abasto, y son la principal fuente de ingresos para el museo.

En consecuencia, la propuesta arquitectónica de ampliación contempla la implementación de:

- 10 talleres nuevos con capacidad de 12 personas cada uno.

- 2 oficinas para uso administrativo

- Depósitos de $1200 \mathrm{~m} 2$

- Un nuevo patio de comidas con distintas ofertas

- Un área de servicio que incluya talleres de capacitación técnica para el personal operativo.

- Sala central expositiva en planta baja de $1500 \mathrm{~m} 2$.

Este programa permitirá duplicar el número de asistentes y visitantes al MALI y llegar a cumplir la meta de los próximos dos años.

Adicionalmente, el programa incluye un estacionamiento para visitantes de eventos particulares en el museo. El Parque de la Exposición tiene un estacionamiento para visitantes en general y para administrativos del Museo. El nuevo estacionamiento también incluiría un montacargas.

El estacionamiento se comunicará con el museo a través de escaleras que llevan a al ingreso principal del museo por el exterior, para iniciar la visita por esa puerta. Luego el visitante puede elegir si lleva el circuito lineal o ingresa directamente a la ampliación subterránea a través de rampas que se encontrarían del lado de la fachada oeste. En este espacio se encontrará la colección de arte contemporáneo del MALI, que en la actualidad está en los depósitos de dicha institución. 


\section{CAPÍTULO VI: CONCLUSIONES FINALES}

\subsection{Conclusiones y consideraciones de diseño}

Para finalizar, luego de haber realizado el trabajo de investigación sobre intervenciones en edificios históricos en distintas regiones del mundo, haber analizado las teorías respecto al tema, y haber realizado observaciones al contexto inmediato del Museo de Arte de Lima, se llega a las siguientes conclusiones:

En primer lugar, el Museo de Arte de Lima se encuentra en un jardín de importancia cultural e histórica para el centro de la ciudad; que es además la entrada al casco antiguo y uno de los principales y pocos pulmones verdes de la zona, junto con el Campo de Marte y el Parque de la Reserva. Por ello, el proyecto de ampliación del MALI debe considerar las necesidades sociales de la comunidad local y también el impacto a nivel metropolitano que tendrá, a través de los estudios pertinentes del área. Asimismo, dicho proyecto debe servir para devolverle a la ciudad este espacio urbano que ha sido depredado con el tiempo, cuyo elemento principal integrador debe ser la propuesta arquitectónica para el museo

A través de los años han existido distintas maneras de conservar, intervenir e inclusive reusar los edificios. El consenso mundial se inclina por una intervención responsable, honesta con su origen y sobre todo que complemente la pieza arquitectónica original, que no la encubra ni imite, sino que colabore a crear un nuevo espacio que potencie la función del mismo.

Esta teoría sobre una intervención crítica está respaldada por organismos internaciones como la UNESCO e ICOMOS, además de compendios como resultados de convenciones en las que se van estableciendo nuevas y mejores maneras de tratar el patrimonio.

Según la normativa vigente para Bienes Culturales Inmuebles del Reglamento Nacional de Edificaciones del Perú, el Museo de Arte de Lima es Monumento Nacional, por lo que se deben de tener en cuenta todas las implicancias que esto acarrea en el momento de plantear el proyecto de ampliación. 
Asimismo, la propuesta debe responder a las necesidades urbanas, arquitectónicas y estéticas del contexto en el que se encuentran el edificio, así también la propuesta paisajística que se haga sobre el Parque de la Exposición.

En segundo lugar, según los referentes analizados, la propuesta para el Museo de Arte de Lima debe evitar competir con el edificio original, por lo que debe cuidar sus dimensiones, así como su forma y ubicación, por eso se sugiere que está última sea subterránea. Además, la diferencia entre ambos edificios debe ser evidente $\mathrm{y}$, sobretodo, se debe prescindir de falsos históricos.

En tercer lugar, si se toman en cuenta las conductas de la población limeña, solo una cuarta parte de las personas considera a los museos como parte de la oferta cultural de la ciudad. Sin embargo, en el caso en particular de este proyecto de ampliación se debe tomar en cuenta que está dentro de un parque monumental, el cual es considerado por más de la mitad de la población el espacio público ideal. Esta idea debe ser aprovechada como un elemento que ayude a crear una interdependencia entre el parque y el museo.

En cuarto lugar, ya que el Parque de la Exposición ha sufrido numerosos cambios y mutilaciones en el tiempo, debe llamar la atención sobre su recuperación y su devolución e integración a la ciudad. El proyecto de ampliación del Museo de Arte de Lima debe incluir un diseño que contemple también su relación con el parque y además la posibilidad de seguir cambiando en el tiempo; versátil y adaptativo a futuro.

En quinto y último lugar, y considerando lo expuesto en este documento, se deben tomar en las siguientes consideraciones de diseño generales para cualquier intervención arquitectónica a realizarse como parte del programa del proyecto de ampliación del Museo de Arte de Lima y puesta en valor del Parque de la Exposición. 


\section{CAPÍTULO VII: PROYECTO}

\subsection{Proyecto}

\subsubsection{Partido arquitectónico}

Como resultado de la investigación realizada en el marco teórico, y luego de considerar las distintas teorías y planteamientos respecto al tema propuesto, las cuatro estrategias que se utilizaron son: la alteración del paisaje a través de la intervención del nivel 0 (parque) por medio de un vacío central y su definición como elemento que integra y permite el ingreso de luz natural, la reinstauración ${ }^{28}$ del espacio público, hundiendo el programa debajo del nivel 0 y continuando el parque sobre ellos, la identificación de edificio y caminos históricos y su rol con los ingresos al nuevo edifico, y la definición de la rampa como elemento de transición entre el exterior y el interior. Estas estrategias son en gran medida las que definieron el diseño final del proyecto, que se superponen y relacionan entre sí: esta intervención no puede ser vista como una suma de partes, sino como un todo, ya que de esa integridad depende la experiencia multisensorial del usuario.

\section{Ilustración 7.1}

El vacío central

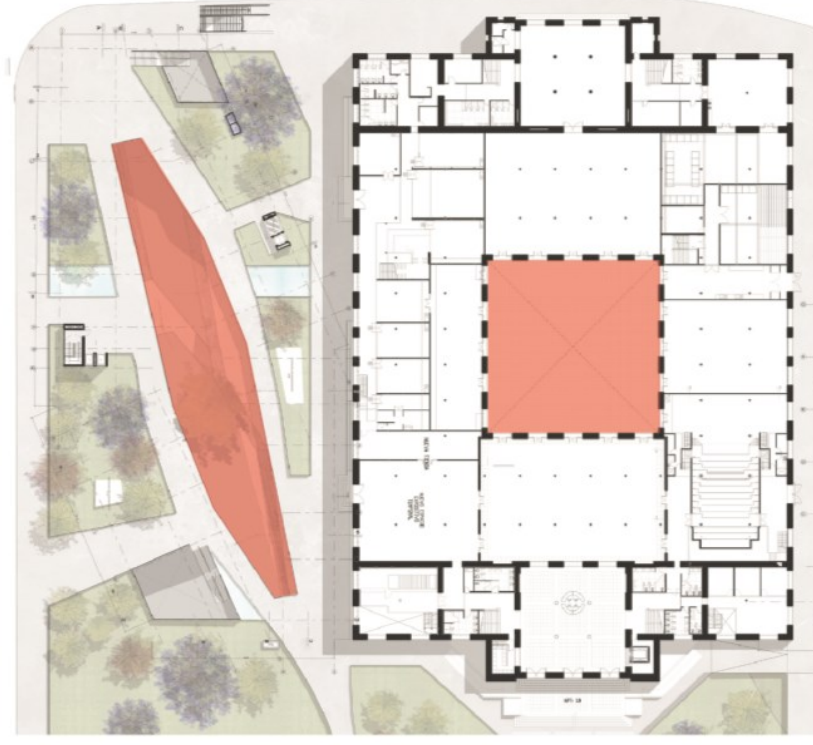

El vacío central: Los usos son agrupados a los lados este y oeste, y los servicios y circulaciones a los extremos norte y sur.

Fuente: Elaboración propia, 2017

\footnotetext{
${ }^{28}$ Reinstauracion: Acción y efecto de restaurar, restablecimiento (RAE, 2017).
} 
Ilustración 7.2.

Programa hundido

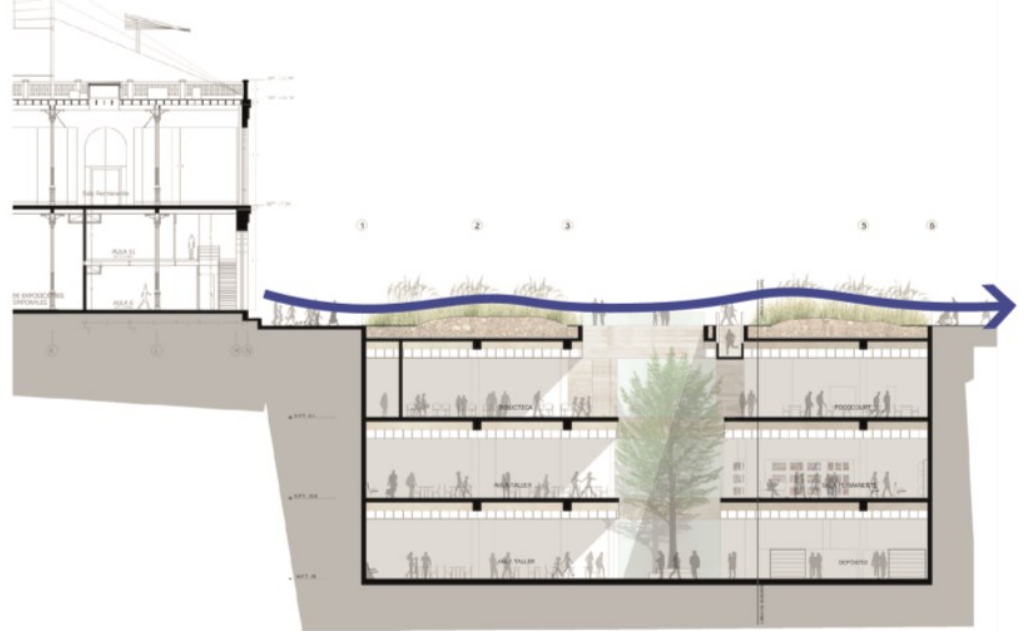

La reinstauración del espacio: El programa se hunde para generar una mayor área de uso público verde en el nivel superior, y así recuperar el carácter de jardín histórico del lugar.

Fuente: Elaboración propia, 2017

La identificación de edificio y caminos históricos: El vacío adquiere una forma diagonal para facilitar la continuación desde el parque, para lo cual se sirve de un camino curvo pre-existente. Este ingreso principal (1) también es el más cercano a la salida oeste de visitantes de MALI. Adicionalmente, existe otro ingreso secundario hacia el norte, próximo a la esquina de Av. Paseo Colón con Av. Wilson (2), y un acceso por medio de ascensores cercano a la última avenida mencionada.

Ilustración 7.3.

El camino

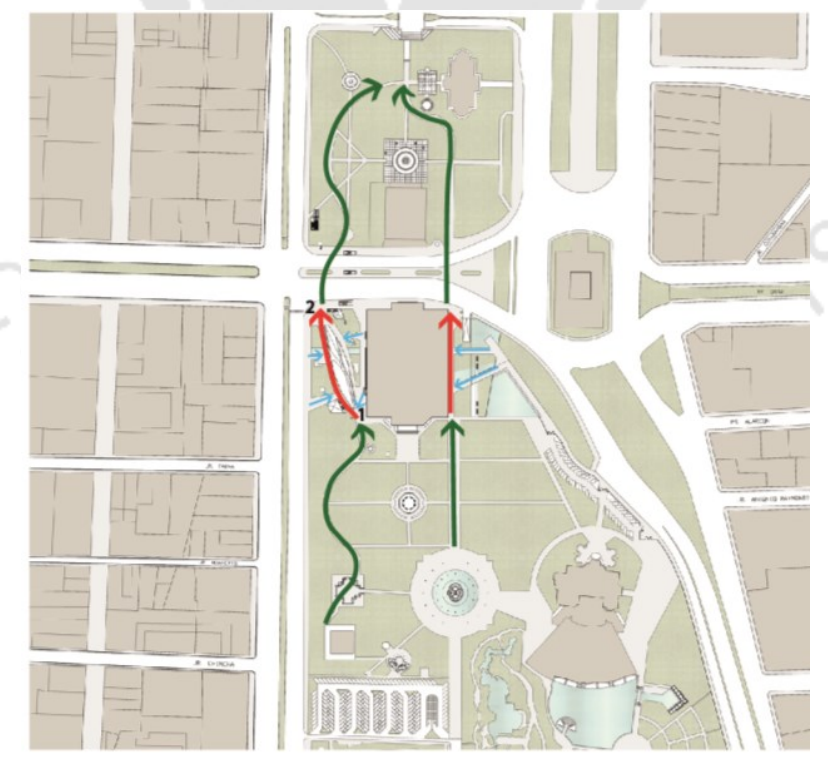

Fuente: Elaboración propia, 2017 
La transición entre el exterior y el interior: El usuario desciende hacia el nuevo edifício por una rampa que inicia por la esquina sureste del proyecto y lentamente va revolviéndose al interior del programa.

Ilustración 7.4.

La rampa

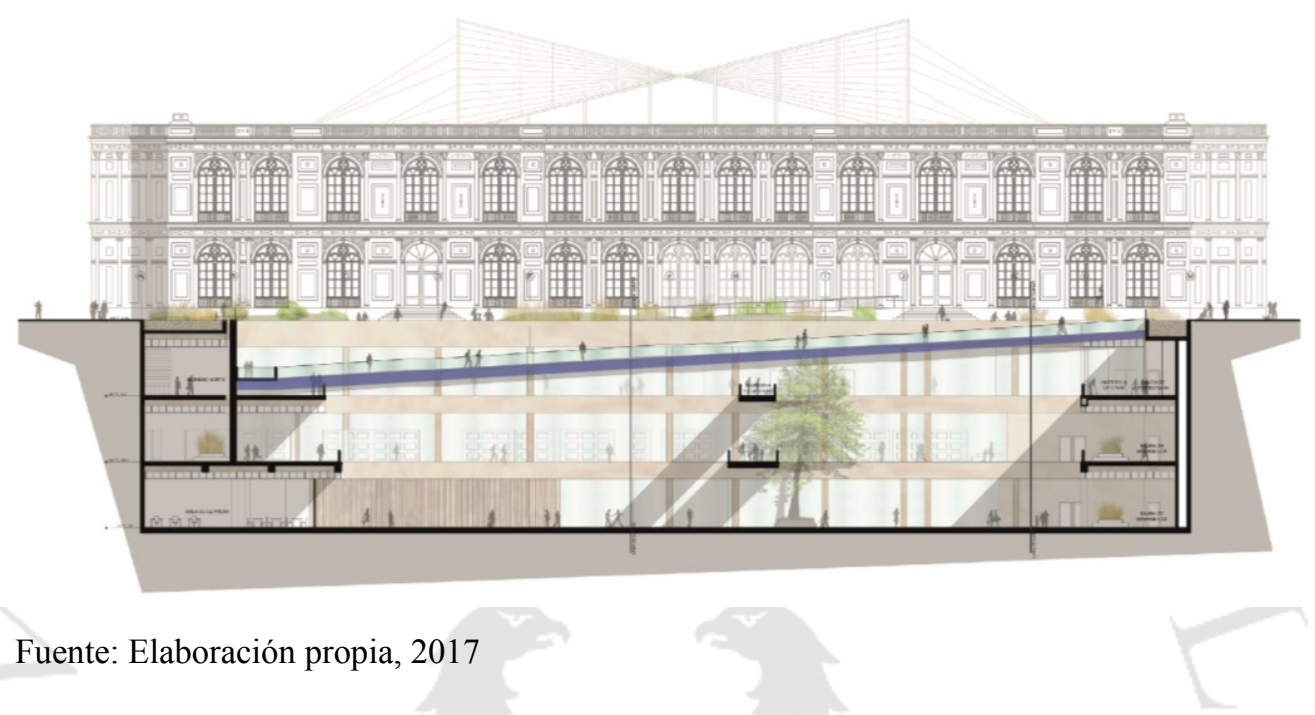

\subsubsection{La ciudad}

La ciudad de Lima carece de un espacio cultural de influencia metropolitana adecuado para la cantidad de personas que la habitan (alrededor de 10 millones según cifras del $\mathrm{INEI}^{29}$ ). Por lo tanto, uno de los objetivos principales del proyecto es convertirse referente de cultura e identidad en el corazón del Centro Histórico de la capital del Perú, ya que albergará, junto con el edificio declarado monumento, la colección más grande arte peruano en el mundo, comprendida entre la época precolombina hasta nuestros días. Adicionalmente, cabe mencionar que la línea 2 del metro de Lima tiene proyectada una estación justo al lado del Museo, por lo que la selección del terreno resulta ideal en términos de accesibilidad y afluencia de personas.

\subsubsection{El entorno - terreno}

El lugar seleccionado para el proyecto se encuentra en el Parque de la Exposición, el cual a su vez se ubica en el Centro Histórico de Lima. Dicho espacio público ha sufrido muchos cambios desde que fue planeado como área de esparcimiento en el siglo XIX. A pesar de ello, existen todavía los trazados originales de los caminos y parte de la vegetación aún se mantiene en pie. La intervención de este espacio tiene como objetivo

29 INEI: Instituto Nacional de Estadística e Informática 
devolver la memoria e identidad al lugar y privilegiar la integración entre los nuevos ingresos y los caminos originales, así como la del parque con el proyecto. La siguiente ilustración muestra cómo se busca continuar el parque: se circunda el edificio con la proyección de los caminos, y estos a su vez son arborizados.

\section{El jardín francés de la Exposición Universal}

Si se observan las imágenes de sus inicios, se ve que el terreno seleccionado estaba rodeado de caminos y senderos que formaban parte de una red integral de vías que recorrían todo el Parque de la Exposición ${ }^{30}$. El proyecto busca continuar este camino curvo e integrase al circuito.

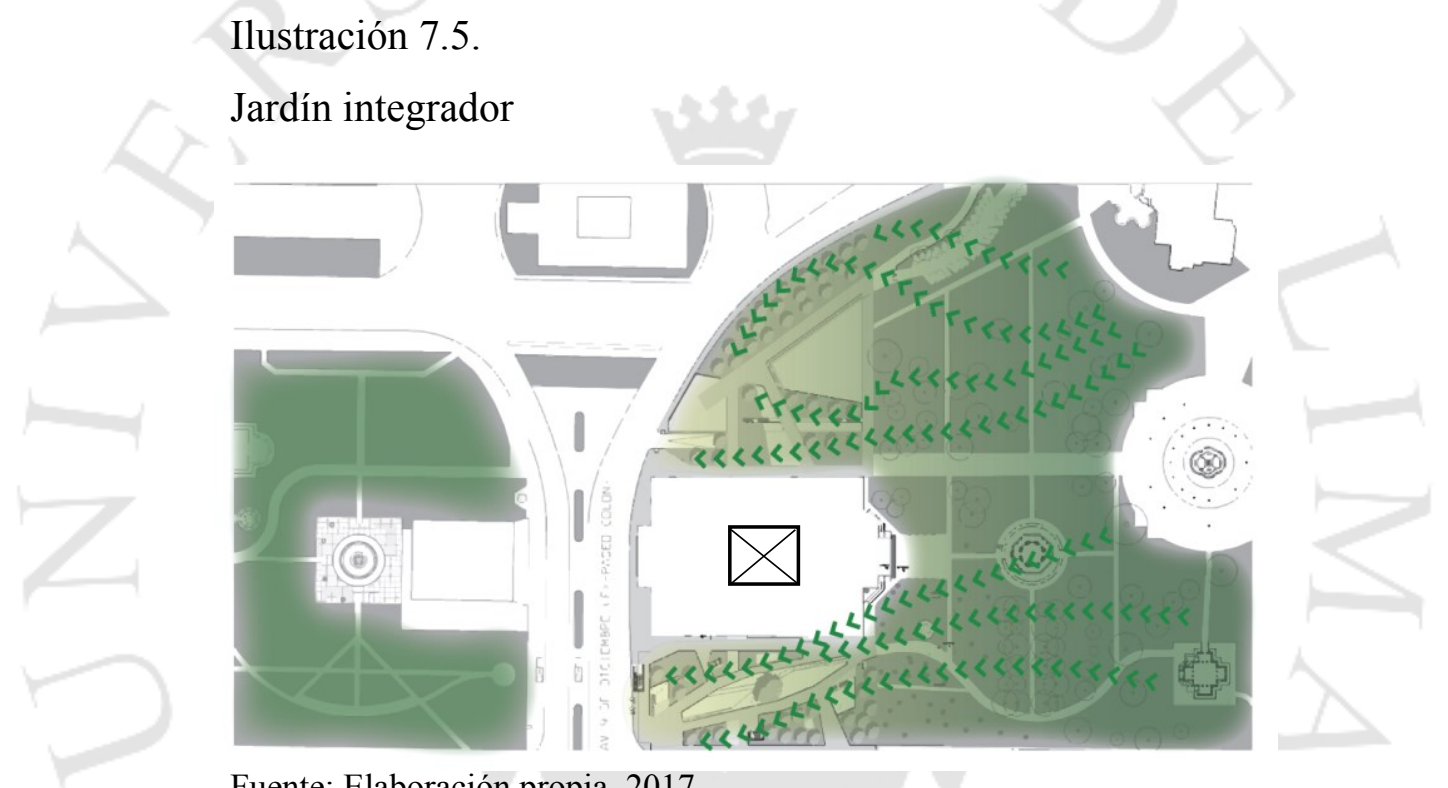

Fuente: Elaboración propia, 2017

En este plano de 1872, vemos la ubicación del Museo y sus jardines alrededor. También se observa que la Avenida 9 de diciembre (actual Paseo Colón), aún no existía, ya que recién se habían tumbado las murallas de Lima, y aún no se habían construido las nuevas vías que servirían para el crecimiento de la ciudad. Tampoco aparece la Avenida Leguía, ni República de Chile, lo que permitió, al menos por unos años, que el Parque de la Exposición estuviese conectado a otro gran parque (de estilo inglés, más rudimentario) que luego se conocería como campo de Marte, y que se vería también muy reducido por el avance de las urbanizaciones.

\footnotetext{
30 En el Marco Referencial se hace una reseña punctual del Parque de la Exposición, y su historia y carácter monumental.
} 
Figura 7.1

Imagen de los jardines del Parque de la Exposición, 1872

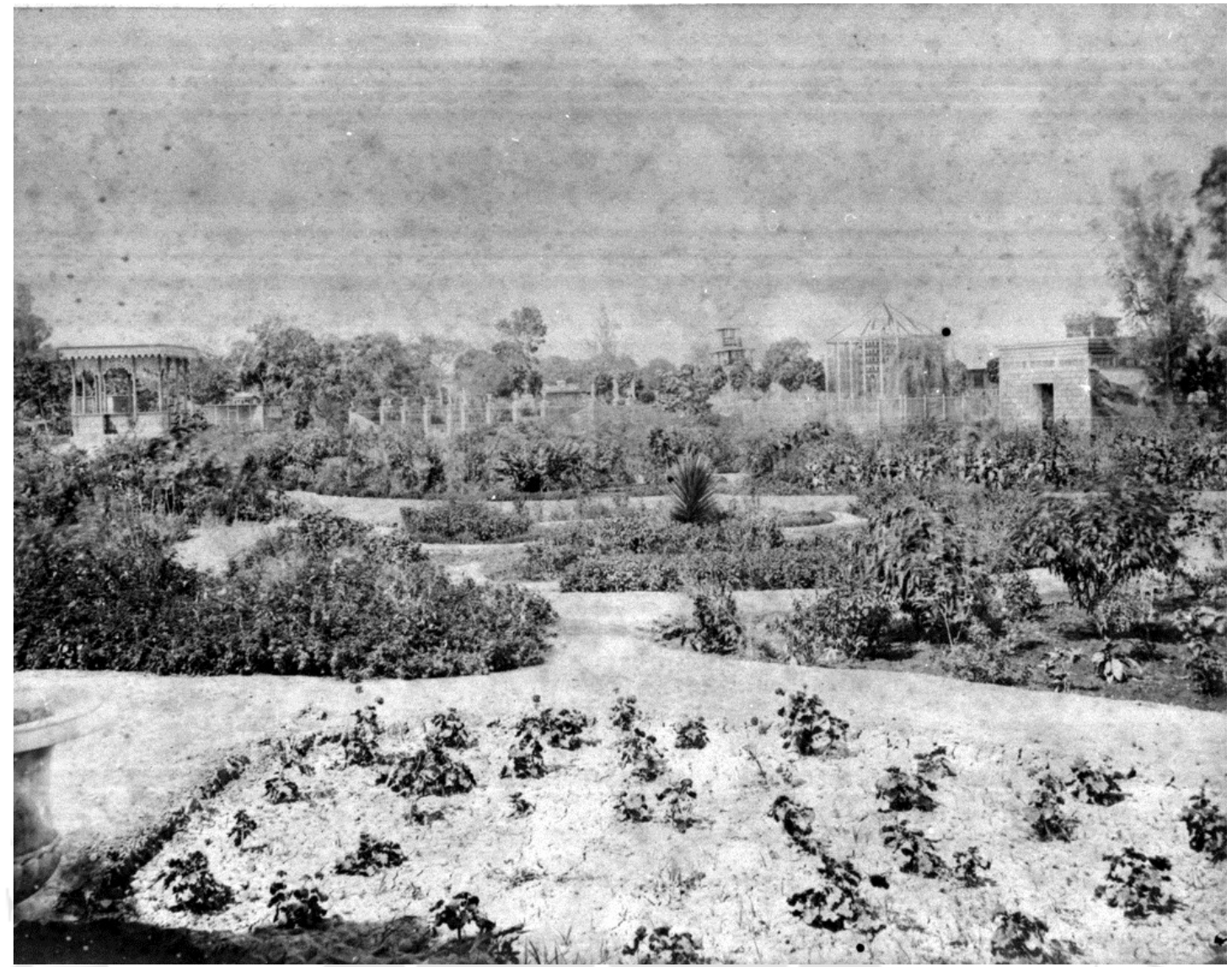

Nota: Imagén original de Estudio Hermanos Courret

Fuente: Archdaily, 2016. Clásicos de Arquitectura: Palacio de la Exposición /

Antonio Leonardi. Recuperado de https://goo.gl/ZZW4r9

Si se mira con detenimiento, puede verse al insipiente camino curvo que atraviesa el parque en dirección suroeste del museo, y que termina integrándose a la red de senderos de los jardines del Palacio de la Exposición.

En los años posteriores, se construirían nuevas avenidas, y el Parque de la Exposición definiría sus linderos y caminos. Parte del Campo de Marte se unió por un tiempo al Parque de la Exposición y fue finalmente divido del primero por la avenida 28 de julio. Esta sección fue también ordenada por medio de caminos y por la colocación de una fuente central, que luego sería adornada por una escultura donada por la colonia China en el Perú para el centenario de la independencia. En las siguientes imágenes se puede ver, que a pesar de que los jardines mantuvieron su carácter ortogonal francés, el antiguo camino curvo se mantuvo, y fue integrado totalmente al diseño de este espacio público. 
Figura 7.2.

Plano del Parque de la Exposición, 1904

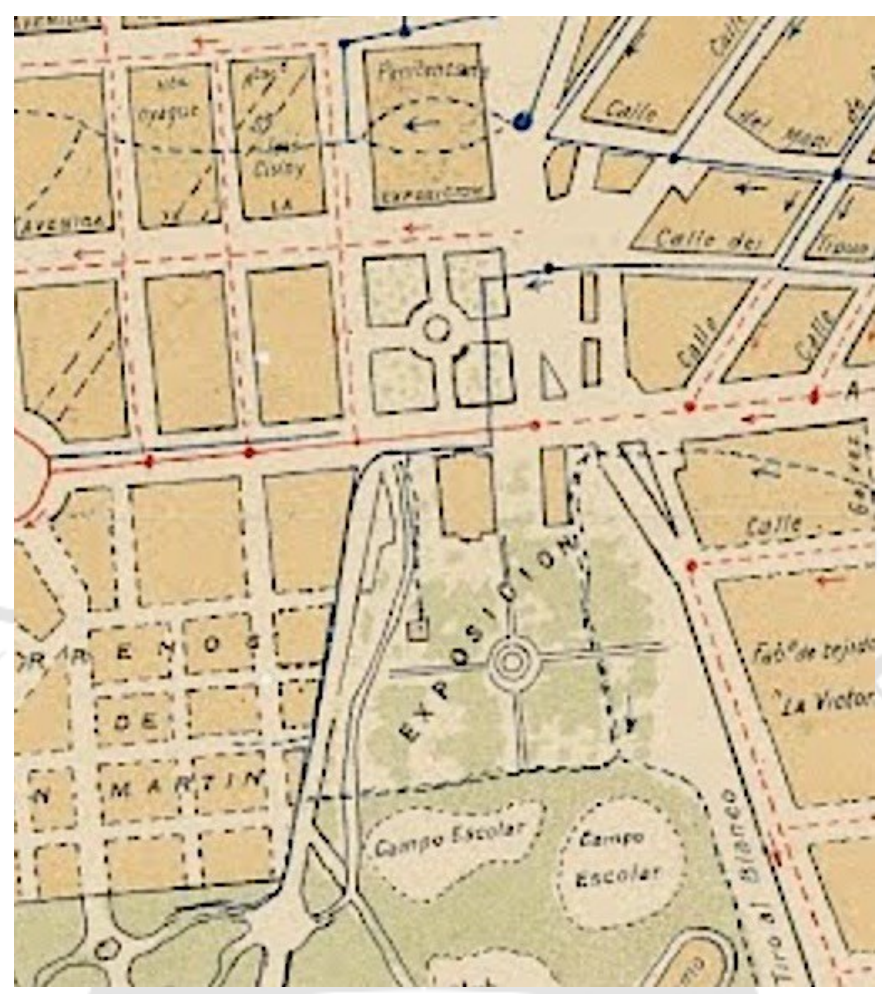

Nota: Los caminos se van definiendo. El camino curvo se parte por la Av. 9 de diciembre.

Fuente: Archivo Bromley y Barbagelata, 1940

Figura 7.3.

Fotografía aérea de la zona, circa 1930.

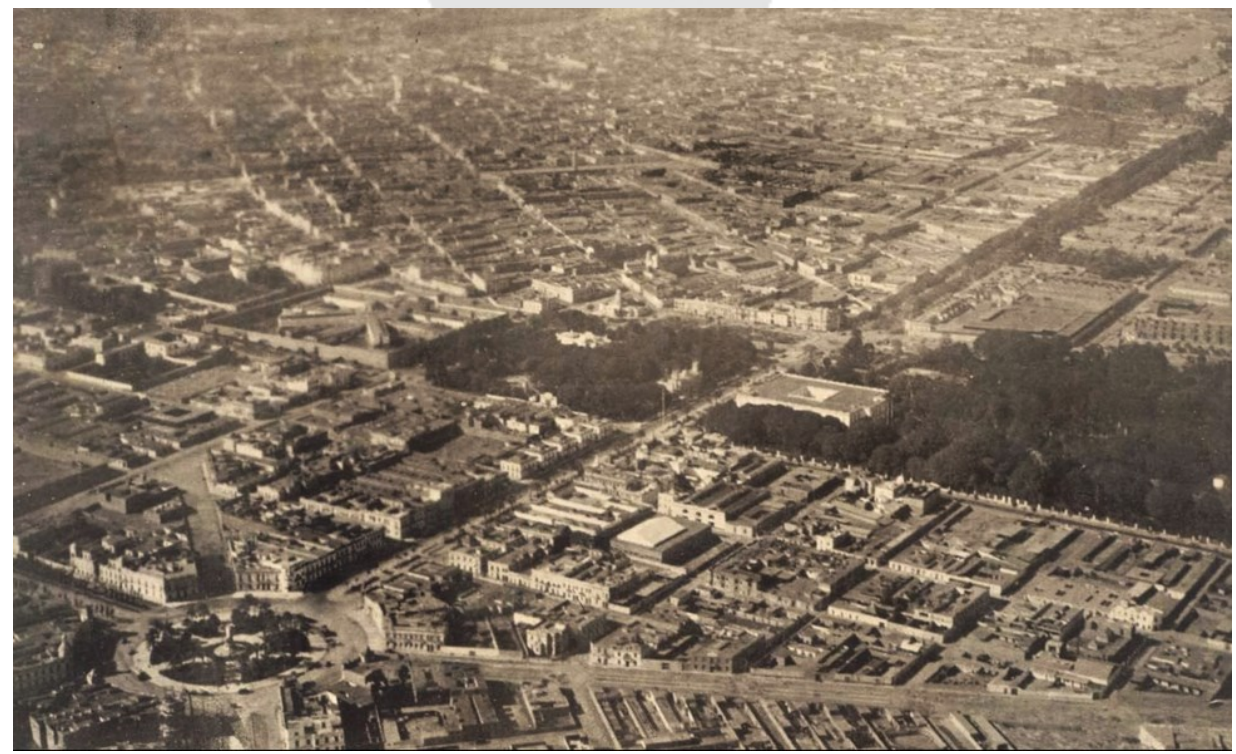

Fuente: Una Lima que se fue, 2010. Retrospectiva 214. Recuperado de https://goo.gl/5fxAF8 


\subsubsection{El usuario}

\section{El perfil del visitante}

El perfil del usuario del MALI y de la zona en cuestión, es variado, aunque se puede afirmar que es un público joven, activo económicamente y que se encuentra estudiando a la vez. Adicionalmente, el museo también cuenta con la visita de niños para los talleres que ofrece, así como la de sus padres o tutores a cargo.

También se recibe la visita de público extranjero, en un amplio rango de edades y nacionalidades, con distintas necesidades individuales.

Por lo tanto, adicionalmente a la ampliación de espacio expositivo con la creación del ala contemporánea, se colocarán aulas para 286 alumnos por turno, que sumados a los que actualmente asisten al edificio antiguo, superarán la proyección de más de 500 alumnos para el 2022. En los siguientes gráficos proporcionados por la Gerencia del MALI se pueden ver dichas proyecciones:

\section{Visitantes por día y proyección}

Tabla 7.1

Visitantes por día

\begin{tabular}{|l|}
\hline \multicolumn{1}{|c|}{ Visitantes por día } \\
\hline Promedio de visitantes por día: \\
Museo (exposiciones): 250 personas \\
Talleres: 200 \\
Total: 450 \\
\hline Proyección en 5 años: 500 personas en los \\
talleres +500 personas en museo $=1000$ \\
personas \\
Proyección en 10 años: 1000 personas en \\
los talleres +1000 personas en museo $=$ \\
2000 personas \\
\hline
\end{tabular}

Fuente: Gerencia MALI, 2016 
Tabla 7.2

Proyección de visitantes hacia el año 2027

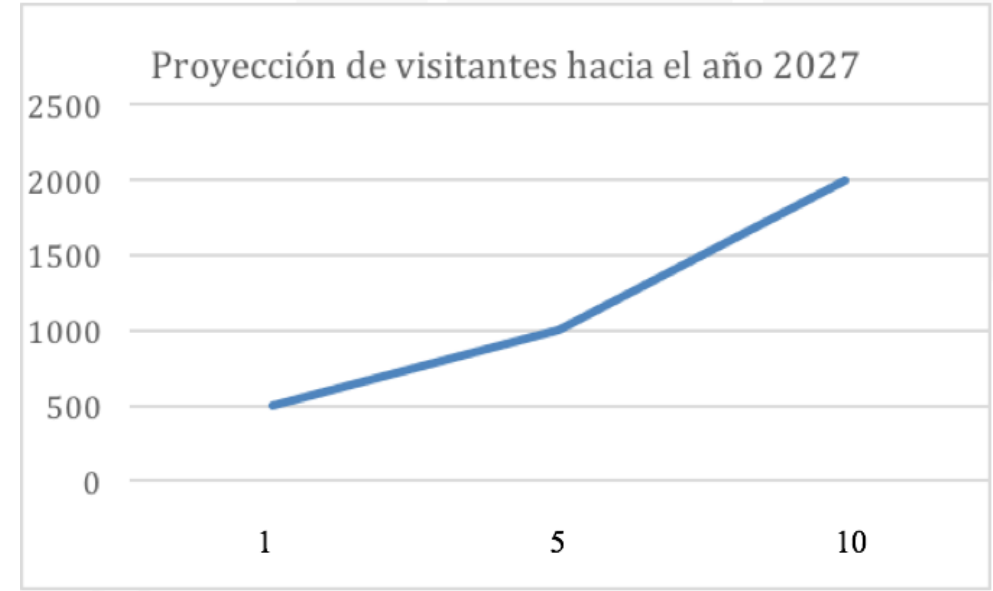

Fuente: Gerencia MALI, 2016

\section{El espacio para las obras en relación al usuario}

Asimismo, es necesario acotar que de las 30 obras de arte contemporáneo que se expondrán en esta ampliación, 12 ya han sido definidas. Basándose en las dimensiones de estas, se elaboró el siguiente gráfico que ilustra el espacio requerido por pieza:

En total, sumarán $1000 \mathrm{~m} 2$ aproximadamente de área expositiva permanente. Cada espacio por obra será de $33 \mathrm{~m} 2$, que incluyen la circulación y el lugar estancia para observar las piezas. Esto permitirá que haya hasta 22 personas por obra, considerando que cada una necesite $1.5 \mathrm{~m} 2$ de espacio individual para circular cómodamente.

Ilustración 7.6.

Área y circulación por pieza exhibida

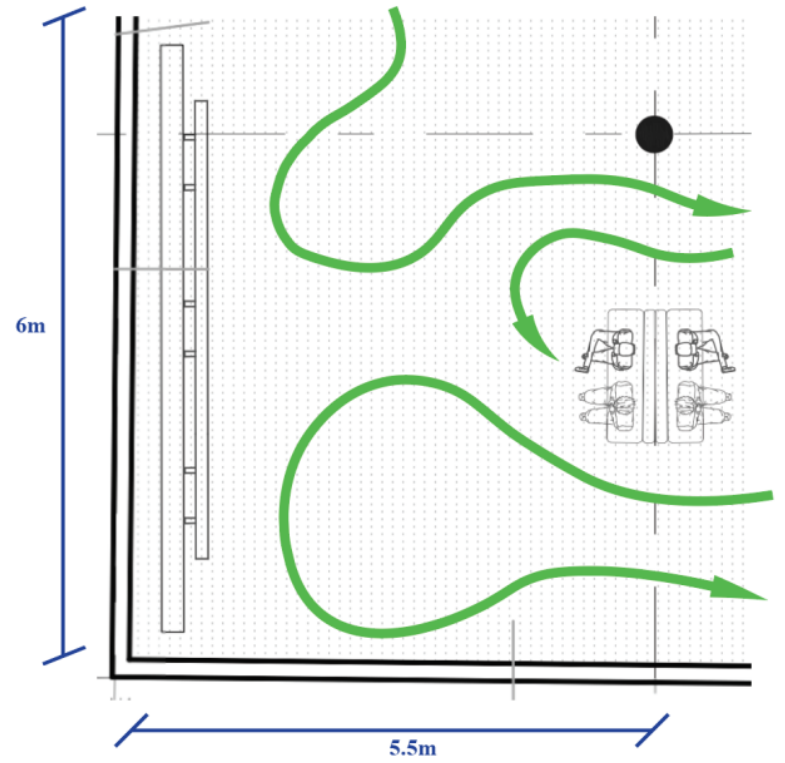

Nota: Área por pieza de arte $33 \mathrm{~m} 2$

Fuente: Elaboración propia, 2017 


\subsubsection{Cálculo de usuarios}

Para el cálculo de usuarios se utilizó la información producto del procesamiento de encuestas y proyecciones esperadas para los próximos 20 años proporcionados por la Gerencia del MALI:

Tabla 7.3.

Cálculo de usuarios

\begin{tabular}{|c|c|}
\hline EXPOSITIVO & 1161 PERSONAS \\
\hline Sala de exhibición permanente & 660 personas \\
\hline Sala de exhibición temporal & 330 personas \\
\hline Depósito general & 50 personas \\
\hline - Depósito de colecciones & 4 personas \\
\hline - Depósito de administración & 2 personas \\
\hline - Depósito de museografía & 4 personas \\
\hline - Taller de carpintería & 20 personas \\
\hline - Taller de mecánica y electrónica & 20 personas \\
\hline Recepción & 109 personas \\
\hline - Taquillas & 4 personas \\
\hline - Guardaropa & 5 personas \\
\hline - Circulación / ingreso / espera & 100 personas \\
\hline SSHH (dos modulos completos) & 12 personas \\
\hline - Caballeros & 6 personas \\
\hline - Damas & 6 personas \\
\hline COMERCIAL & 475 personas \\
\hline Patio de comidas & 463 personas \\
\hline - Cocina 1 & 5 personas \\
\hline - Cocina 2 & 5 personas \\
\hline - Barras & 3 personas \\
\hline - Área de comensales & 450 personas \\
\hline SSHH & 12 personas \\
\hline - Caballeros & 6 personas \\
\hline - Damas & 6 personas \\
\hline EDUCATIVO & 387 personas \\
\hline Aulas (11 aulas de 26 alumnos por turno) & 286 personas \\
\hline Biblioteca & 75 personas \\
\hline - Sala de lectura y referencia & 72 personas \\
\hline - Recepción & 4 personas \\
\hline - Almacén de libros & 2 personas \\
\hline Deposito académico & 2 personas \\
\hline Oficinas & 12 personas \\
\hline - Administrador & 1 personas \\
\hline - Coordinadores & 5 personas \\
\hline - Asistentes/secretarias & 6 personas \\
\hline SSHH (dos modulos completos) & 12 personas \\
\hline - Caballeros & 6 personas \\
\hline - Damas & 6 personas \\
\hline SERVICIOS Y SISTEMAS & 80 personas \\
\hline Talleres para trabajadores ( 2 de 30 alumnos) & 60 personas \\
\hline Cuarto de bombas & 2 personas \\
\hline Cuarto de tableros & 2 personas \\
\hline Generador eléctrico & 2 personas \\
\hline Cuarto de control y seguridad & 2 personas \\
\hline SSHH & 12 personas \\
\hline - Caballeros & 6 personas \\
\hline - Damas & 6 personas \\
\hline
\end{tabular}

Nota: Programa dividido por área expositiva, comercial, educativa, y servicios y sistemas, para un total de 2103 personas. Fuente: Elaboración propia, 2017 


\subsubsection{Programa general por áreas}

La siguiente tabla muestra el programa general por áreas del proyecto y el total de área construida techada. Se incluye también la circulación, y adicionalmente, se menciona la cantidad de área libre proyectada.

Tabla 7.4.

Programa general por áreas

\begin{tabular}{|c|c|}
\hline EXPOSITIVO & $2840 \mathrm{M} 2$ \\
\hline Sala de exhibición permanente & $1000 \mathrm{~m} 2$ \\
\hline Sala de exhibición temporal & $500 \mathrm{~m} 2$ \\
\hline Depósito general & $1030 \mathrm{~m} 2$ \\
\hline - Depósito de colecciones & $700 \mathrm{~m} 2$ \\
\hline - Depósito de administración & $50 \mathrm{~m} 2$ \\
\hline - Depósito de museografía & $200 \mathrm{~m} 2$ \\
\hline - Taller de carpintería & $50 \mathrm{~m} 2$ \\
\hline - Taller de mecánica y electrónica & $30 \mathrm{~m} 2$ \\
\hline Recepción & $250 \mathrm{~m} 2$ \\
\hline - Taquillas & $25 \mathrm{~m} 2$ \\
\hline - Guardaropa & $25 \mathrm{~m} 2$ \\
\hline - Circulación / ingreso / espera & $200 \mathrm{~m} 2$ \\
\hline SSHH (dos modulos completos) & $60 \mathrm{~m} 2$ \\
\hline - Caballeros & $30 \mathrm{~m} 2$ \\
\hline - Damas & $30 \mathrm{~m} 2$ \\
\hline COMERCIAL & $510 \mathrm{~m} 2$ \\
\hline Patio de comidas & $450 \mathrm{~m} 2$ \\
\hline - Cocina 1 & $35 \mathrm{~m} 2$ \\
\hline - Cocina 2 & $35 \mathrm{~m} 2$ \\
\hline - Barras & $30 \mathrm{~m} 2$ \\
\hline - Área de comensales & $350 \mathrm{~m} 2$ \\
\hline SSHH & $60 \mathrm{~m} 2$ \\
\hline - Caballeros & $30 \mathrm{~m} 2$ \\
\hline - Damas & $30 \mathrm{~m} 2$ \\
\hline EDUCATIVO & $1810 \mathrm{~m} 2$ \\
\hline Aulas ( 11 aulas de 26 alumnos por turno) & $1200 \mathrm{~m} 2$ \\
\hline Biblioteca & $390 \mathrm{~m} 2$ \\
\hline - Sala de lectura y referencia & $120 \mathrm{~m} 2$ \\
\hline - Recepción & $30 \mathrm{~m} 2$ \\
\hline - Almacén de libros & $240 \mathrm{~m} 2$ \\
\hline Deposito académico & $60 \mathrm{~m} 2$ \\
\hline Oficinas & $100 \mathrm{~m} 2$ \\
\hline - Administrador & $20 \mathrm{~m} 2$ \\
\hline - Coordinadores & $45 \mathrm{~m} 2$ \\
\hline - Asistentes/secretarias & $35 \mathrm{~m} 2$ \\
\hline SSHH (dos modulos completos) & $60 \mathrm{~m} 2$ \\
\hline - Caballeros & $30 \mathrm{~m} 2$ \\
\hline - Damas & $30 \mathrm{~m} 2$ \\
\hline SERVICIOS Y SISTEMAS & $265 \mathrm{~m} 2$ \\
\hline Talleres para trabajadores ( 2 de $\mathbf{3 0}$ alumnos) & $80 \mathrm{~m} 2$ \\
\hline Cuarto de bombas & $30 \mathrm{~m} 2$ \\
\hline Cuarto de tableros & $25 \mathrm{m2}$ \\
\hline Generador eléctrico & $45 \mathrm{~m} 2$ \\
\hline Cuarto de control y seguridad & $25 \mathrm{~m} 2$ \\
\hline SSHH & $60 \mathrm{m2}$ \\
\hline - Caballeros & $30 \mathrm{~m} 2$ \\
\hline - Damas & $30 \mathrm{~m} 2$ \\
\hline Circulación (15\%) & $831.75 \mathrm{m2}$ \\
\hline TOTAL DE ÁREA CONSTRUIDA TECHADA & $6376.75 \mathrm{~m} 2$ \\
\hline TOTAL DE ÁREA LIBRE & $819.65 \mathrm{m2}$ \\
\hline
\end{tabular}

Nota: Programa dividido por área expositiva, comercial, educativa, y servicios y sistemas. El área total construida es de $6376.75 \mathrm{~m} 2$

Fuente: Elaboración propia, 2017 


\subsubsection{Trazado por camino e ingresos}

El trazo diagonal del ingreso a través de la rampa del edifico obedece en primer lugar al camino original curvo que atravesaba esta zona del parque. También, se utilizó esa linea guía para generar la forma nuevo predio de tal manera que facilitará la conexión con los accesos existentes desde el MALI.

Ilustración 7.7.

Trazado de caminos e ingresos

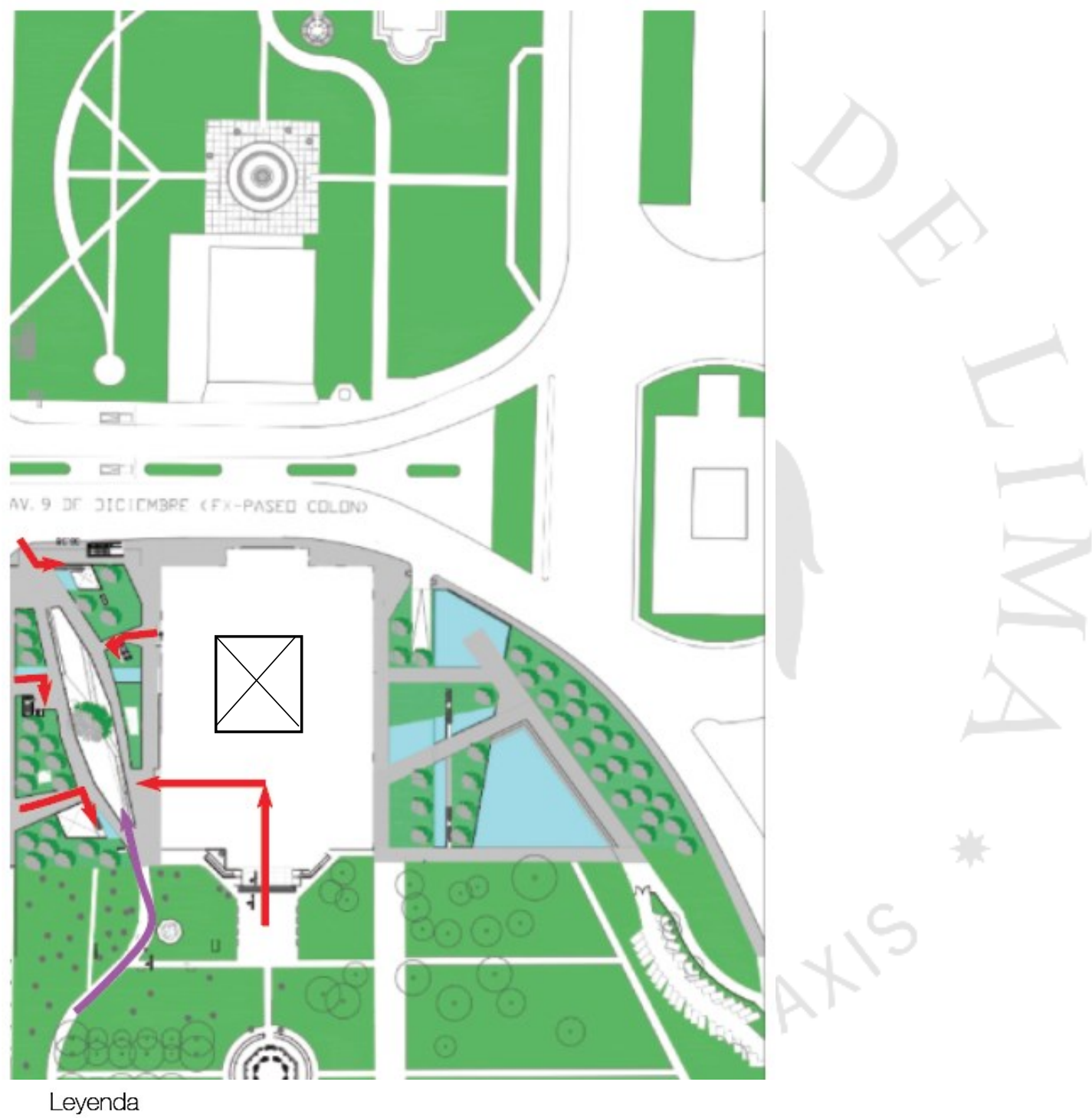

Las lineas de trazado obecen principalmente al camino original curvo que atravesaba esta zona del parque. Entonces, se utilizó esa linea gula para generar la forma del edificio de tal manera que facilitará la conexión con los accesos existentes.

\footnotetext{
$<$ Linea gula integrada con la trama de caminos Ingresos
}

Fuente: Elaboración propia, 2017 


\subsubsection{Activación por flujos de usuarios}

Ilustración 7.8.

Activación por flujos de usuarios

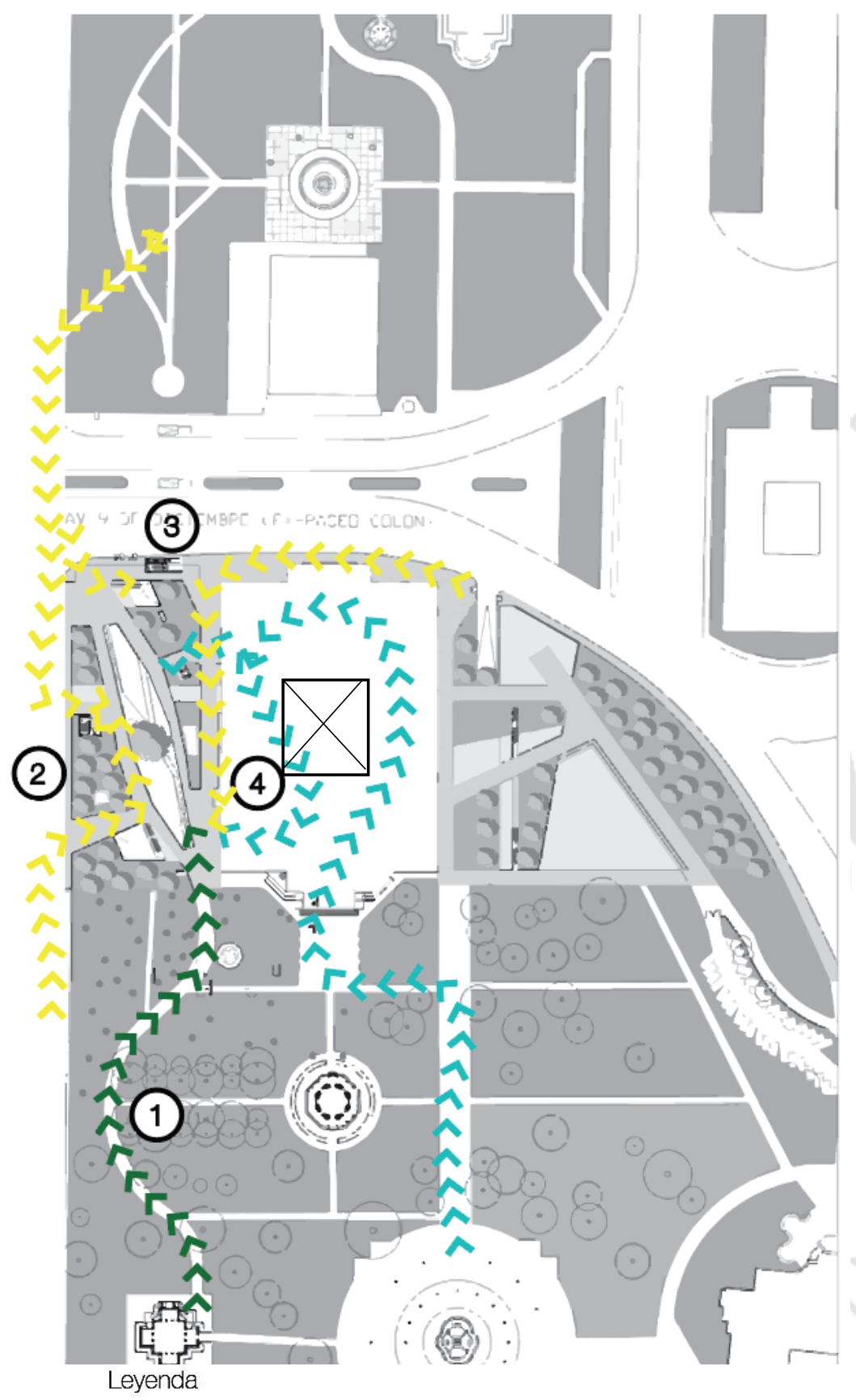

Luego de haberse realizado el trazado considerando el camino e ingresos, se procede mostrar los nuevos flujos de usuarios en la propuesta:

$<<1$. Desde el parque

$<<2$. Desde Wilson

$<<3$. Desde Pase Colón

$<<4$. Desde el MALI

Fuente: Elaboración propia, 2017 


\subsubsection{Paisaje y superficies}

Se han considerado materiales y vegetación local para asegurar un mantenimiento sostenible y adecuado en el tiempo. El gráfico (ver ilustración 7) la composición del piso de tierra donde ser ubicará la vegetación. La profundidad va desde $1.00 \mathrm{~m}$ a $1.20 \mathrm{~m}$ para la parte designada a arbole medianos.

\section{Ilustración 7.9}

Detalle de techo verde

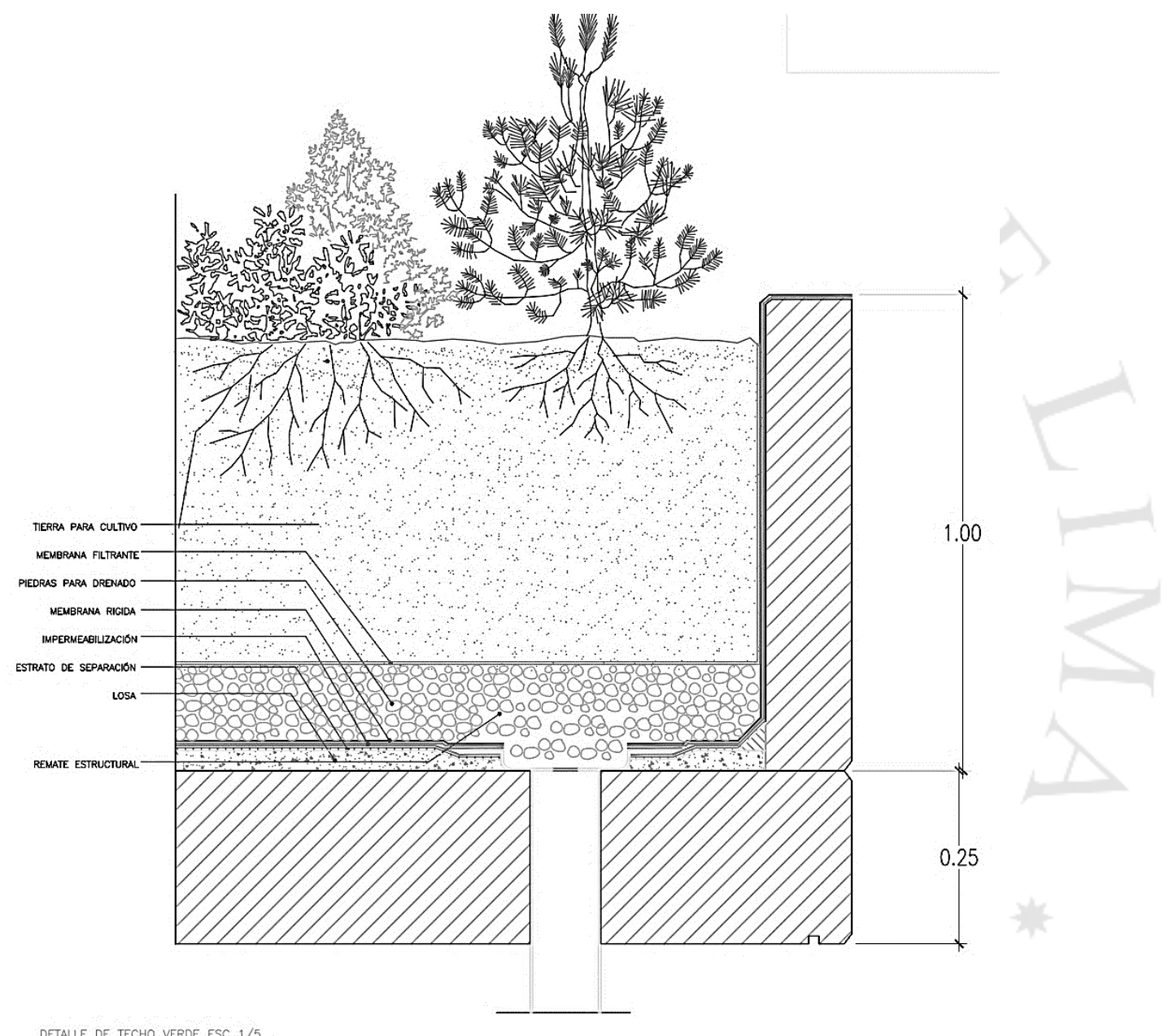

Fuente: Elaboración propia, 2017

\section{Materiales para superficies}

Se utiliza con adoquines para continuar los caminos, espejos de agua y plantas rastreras en las áreas verdes para cubrir las superficies. Los espacios verdes estarán delimitados por muros bajos de entre $30 \mathrm{~cm}$ a $40 \mathrm{~cm}$ de concreto. Adicionalmente, se proyectaron arbustos y árboles medianos de sombra de raíces superficiales. 
Paisaje verde e integradorEl usuario en la actualidad sólo utiliza la esquina de Paseo Colón con Wilson como lugar de paso y de paradero informal. El proyecto busca integrar esta intersección al parque, e invitar a los ciudadanos de a pie a que utilizan este nuevo espacio público, sin barreras, con actividades culturales, comerciales y priorizando el lugar del peatón sobre los autos y transporte público.

Figura 7.4.

Vista de la esquina de la Av. Wilson y Paseo Colón actualmente

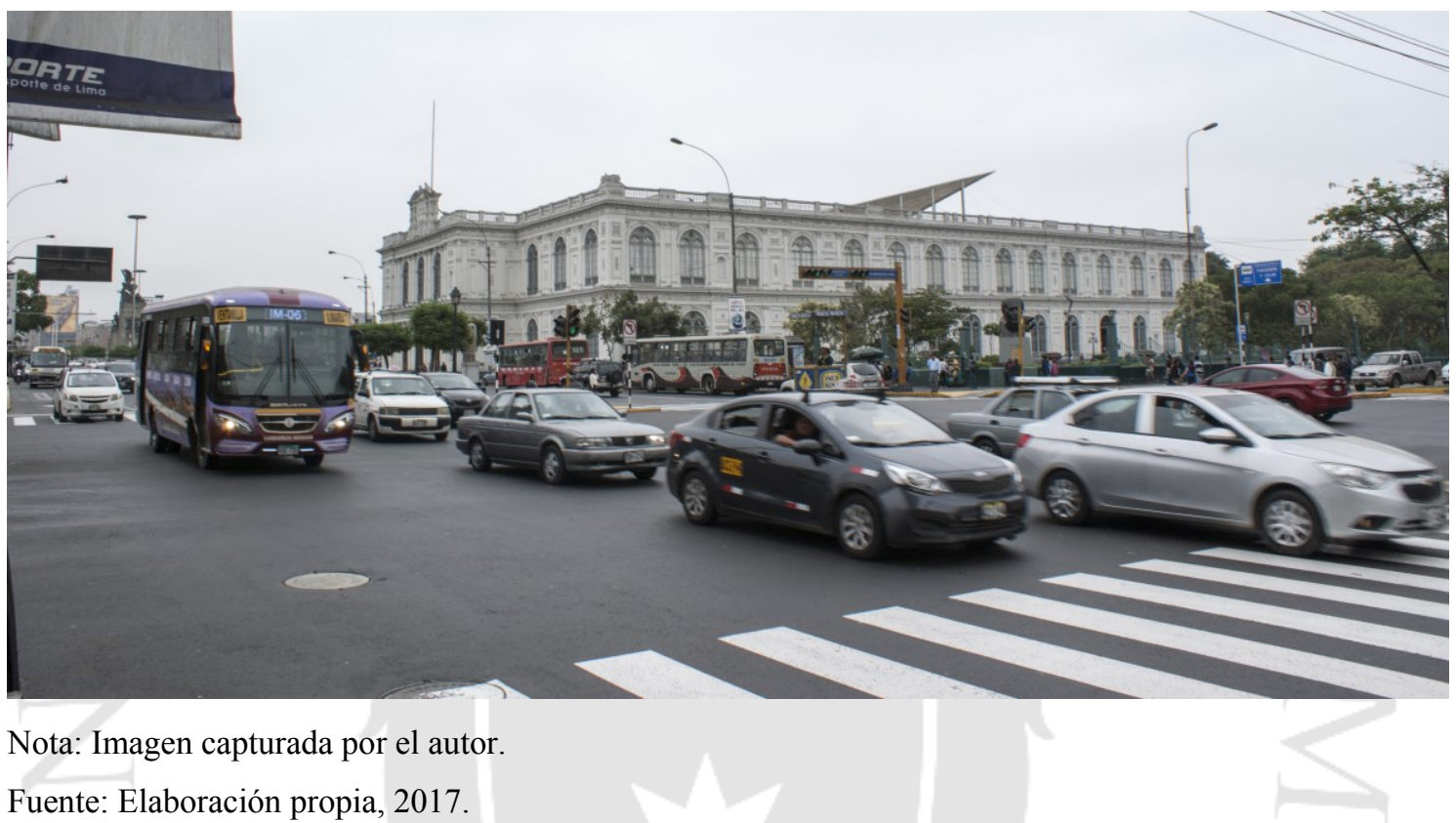

Por lo tanto, se ha diseñado un techo verde sobre todo el edificio nuevo. Este tendrá dos funciones principales:

1. Regenerar la esquina de Paseo Colón y Wilson, para así proveer a las personas con un espacio amable de estancia y paso, con sombra y adecuada circulación.

2. Sostener la topografía y permitir crecimiento normal de las plantas especialmente propuestas para este diseño de distintos niveles que a su vez servirá para integrar las salidas y cajas de ascensores al paisaje.

Ilustración 7.10

Corte de paisaje de nivel $+/-0.00$ de sección de parque con proyecto

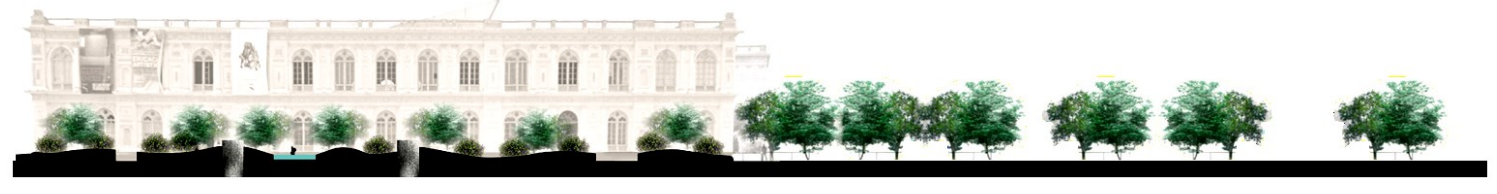

Fuente: Elaboración propia, 2017

En la ilustración 7.10 se observa como el proyecto integra y continua el Parque de la Exposición al contorno del MALI. 
Ilustración 7.11

Corte de paisaje de nivel +/- 0.00 de sección de ampliación del MALI

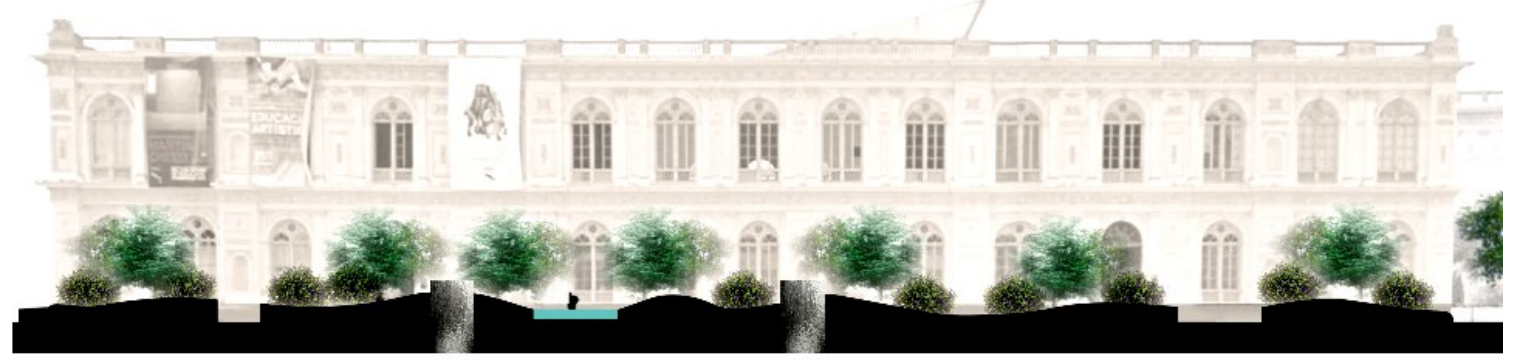

Fuente: Elaboración propia, 2017

La ilustración 7.11 muestra como las cajas de ascensores y accesos quedan prácticamente ocultos por las curvas de nivel y vegetación propuesta.

Las partes que este techo tendrá son las siguientes:

- Techo de concreto: parte de la estructura principal del edificio

- Geomembrana: protege a la estructura de la humedad.

- Celda de drenaje: lleva el agua de riego al desagüe designado únicamente para este propósito.

- Lamina geotextil: estructura rígida que protege al edificio de las raíces de las plantas.

- Tierra vegetal: tierra rica en proteínas para el crecimiento de las plantas.

- Vegetación: de acuerdo a diseño, rastreras y arbustos medianos que sigan la lógica de jardín propuesta.

En el gráfico siguiente se puede ver una sección isométrica de la propuesta de techo:

Figura 7.5

Isometría de techo verde

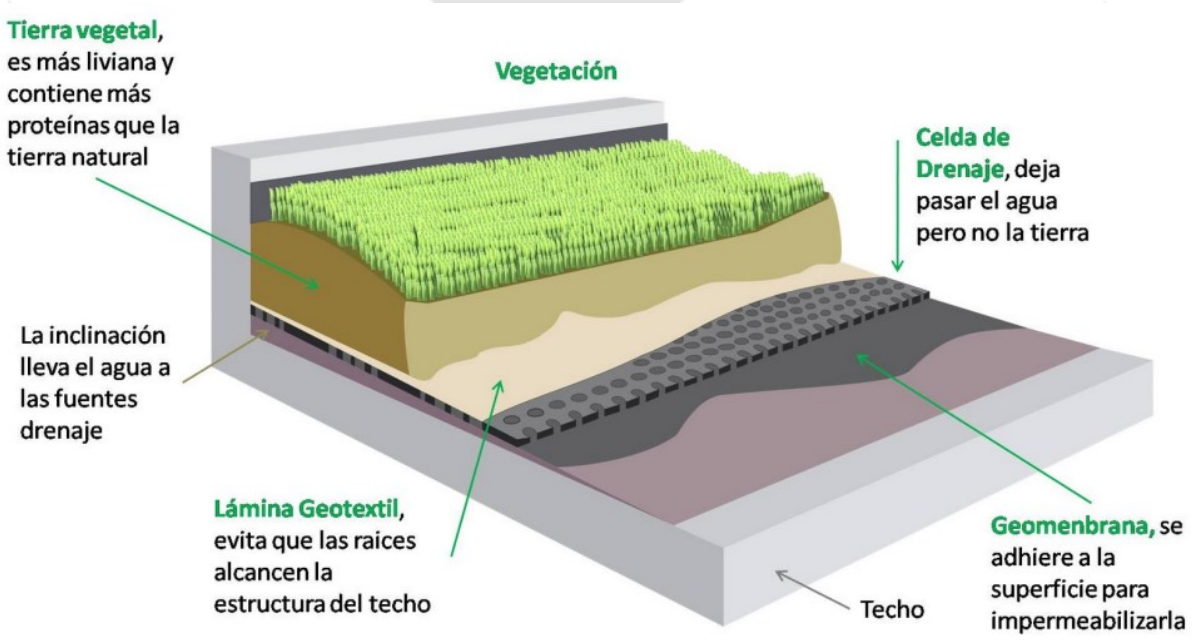

Fuente: Techos Verdes, 2011. Productos para techos verdes. Recuperado de https://goo.gl/cuwlp8 
El techo verde propuesto es de tipo intensivo, lo que implica que el grosor del mismo, en sus puntos más altos, debe ser de $1.20 \mathrm{~cm}$ y tener una capacidad de carga de una tonelada por m2; aquí se colocaran los siguientes árboles: jacaranda, hibiscus tiliaceus y lasgerstroemia indica. En las partes más bajas, puede llegar a medir entre $0.22 \mathrm{~m}$ y $0.32 \mathrm{~m}$, donde se colocarán plantas de menores dimensiones acordes a la capacidad de carga y grosor de la tierra (e.j. Croposma). Ver planos anexos para detalles constructivos y arbustos propuestos.

\section{Sostenibilidad}

El Parque de la Exposición, así como el Parque de la Reserva, tienen un riego por goteo centralizado conectado a un pozo natural, que ahorra hasta en un $80 \%$ del consumo si lo comparamos con el riego por inundación. Para preservar aún más el uso del agua, la propuesta incluye utilizar rastreras xerófilas (ver Plotplan adjunto).

El proceso de riego por goteo empieza llevando el agua hacia un sistema de filtros en dos etapas, para luego, una vez limpia (no potable), ser impulsada por bombeo hacía unos canales subterráneos ubicados a manera de grilla en el jardín o parque. Estos son permeables y permiten el paso lento del agua. El sistema utiliza un cronómetro para ir dosificando el agua de acuerdo al programa de riego y necesidades de las plantas.

\section{Figura 7.6}

Características del sistema de riego por goteo

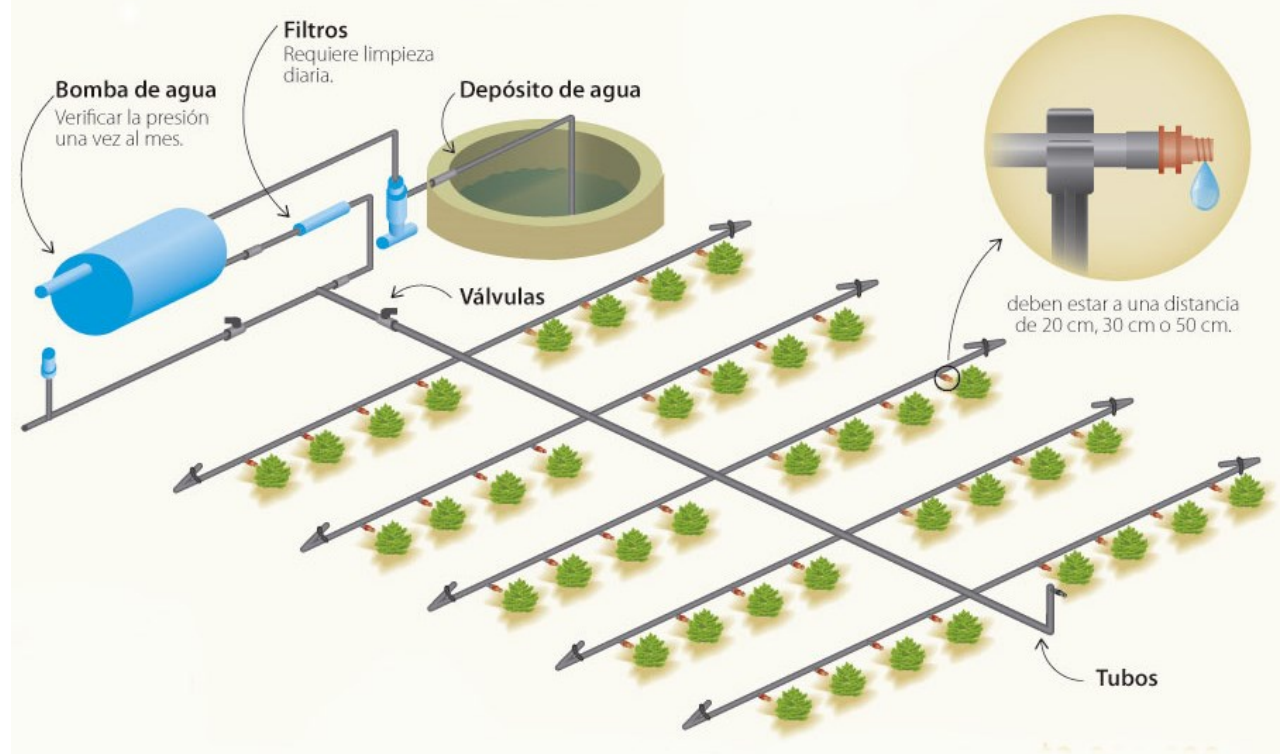

Fuente: Gestiriego, (s.f.). Componentes instalación riego por goteo. Recuperado de https://goo.gl/mXigdy 


\subsubsection{Cabida con zonificación de áreas por piso}

Ilustración 7.12

Cabida de áreas

\section{Cabida de zonificación}

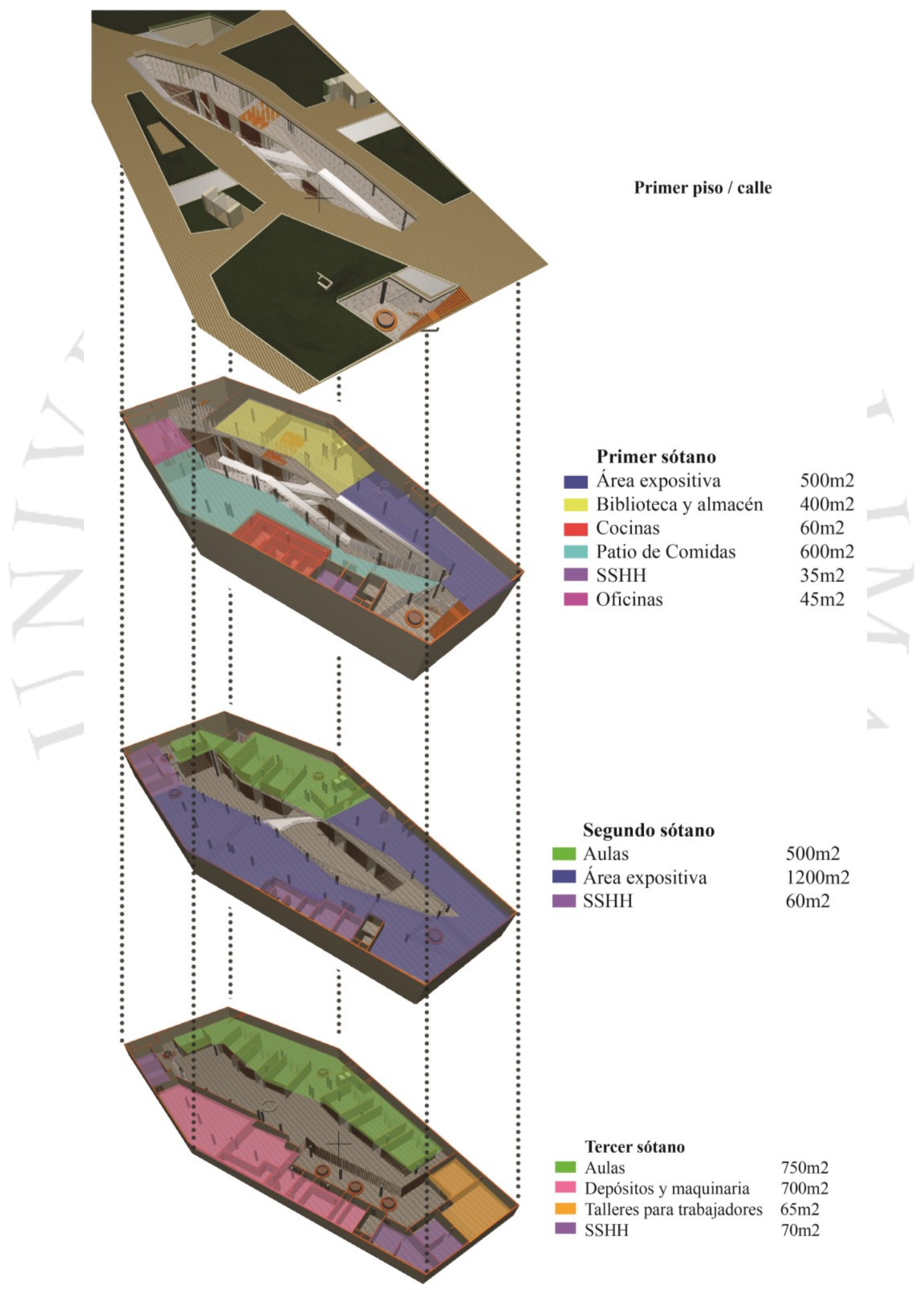

Fuente: Elaboración propia, 2017 


\subsubsection{Zonificación en corte}

En las siguientes láminas, se observa el proyecto en dos cortes longitudinales. El primer corte interior muestra que los espacios destinados al libre acceso, como el patio de comidas o las oficinas (matriculas) están más cerca de la superficie, mientras que los depósitos y aulas en los pisos inferiores. La sala expositiva permanente en medio integra ambos niveles al ser un ambiente de diáfano.

Ilustración 7.13

Corte esquemático longitudinal X

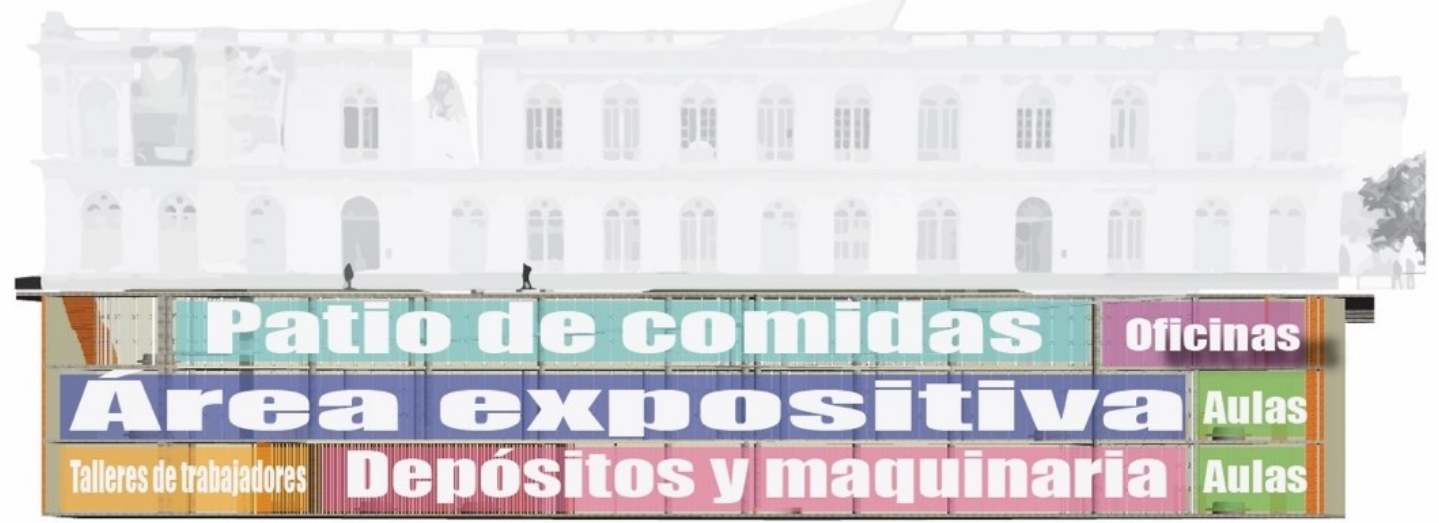

\section{Corte longitudinal $\mathbf{X}$}

Fuente: Elaboración propia, 2017

En el segundo corte, se ve la misma lógica que en la gráfica anterior. La biblioteca de uso público y la sala expositiva temporal están más cerca de la superficie que el resto del programa para facilitar y agilizar la rotación de personas. Por otro lado, las aulas y el área expositiva permanente están por debajo ya que su uso es más prolongado y en horarios establecidos, usualmente con asistencias programadas.

Ilustración 7.14

Corte esquemático longitudinal Z

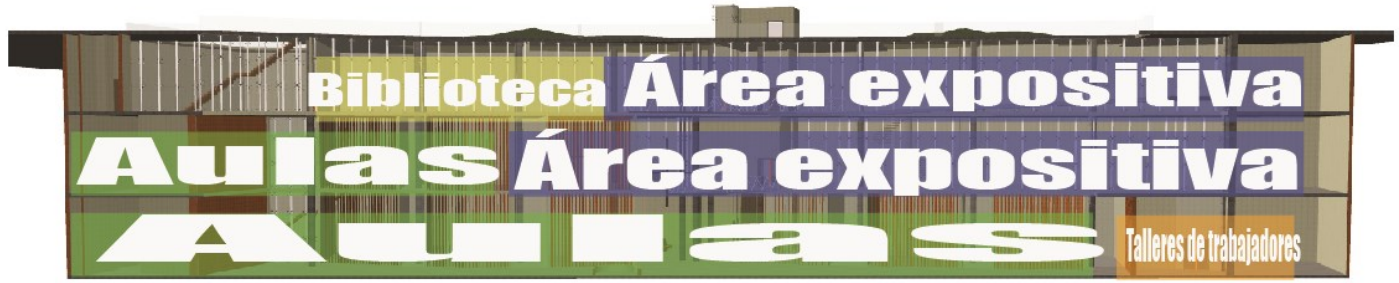

Corte longitudinal $\mathrm{Z}$

Fuente: Elaboración propia, 2017 
Ilustración 7.15

Corte esquemático transversal Y

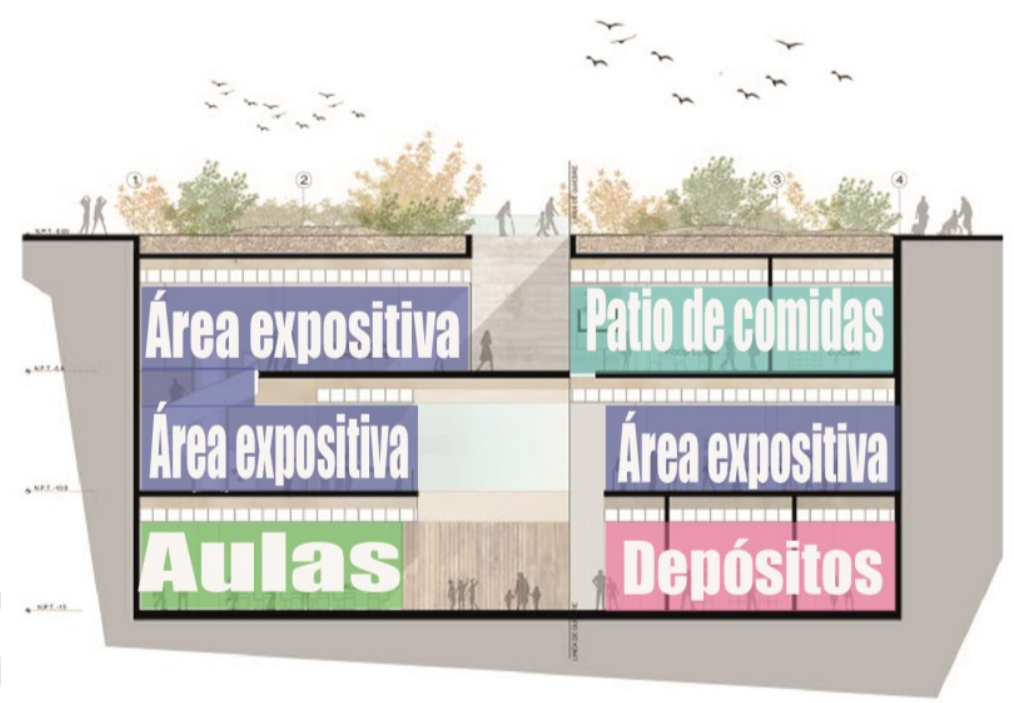

Fuente: Elaboración propia, 2017

En el tercer corte, el mismo patio de comida de uso público y la sala expositiva temporal están más cerca de la superficie que el resto del programa para facilitar y agilizar la rotación de personas. Por otro lado, el área expositiva permanente está por debajo ya que su uso es más prolongado y en horarios establecidos, a veces con asistencias programadas. Al fondo se encuentran las aulas y depósitos de uso restringido.

\subsubsection{Diagrama funcional}

Diagrama 7.1

Diagrama de programa funcional

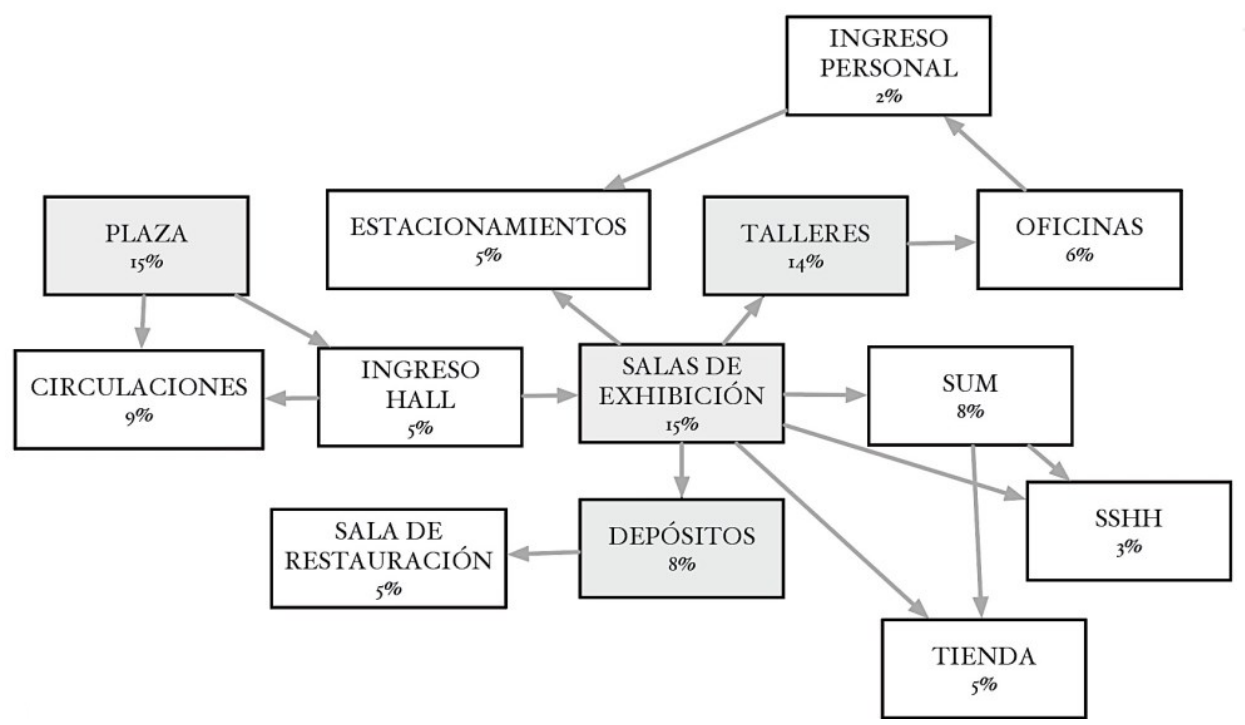

Nota: Los ambientes principales están representados en gris, los secundarios, en blanco.

Fuente: Elaboración propia, 2015 


\subsection{Viabilidad}

\subsubsection{Gestión y viabilidad}

Para el presente proyecto, se han evaluado distintas formas de financiamiento, previo análisis de factibilidad de acuerdo al reglamento regente. Adicionalmente, se ha revisado el costo-beneficio no sólo económico sino social que una ampliación de esta magnitud traería al Patronato de las Artes, ente administrador del Museo de Arte de Lima.

\subsubsection{Identificación y tipo de producto}

El Museo de Arte de Lima, ubicado en el Parque de la Exposición, es la institución más importante en su tipo en el Perú. Cuenta con una colección de incalculable valor histórico artístico de nuestro país. Asimismo, el edificio en el que se encuentra tiene valor patrimonial ya que es una pieza única de la arquitectura ecléctica del siglo XIX en la ciudad.

\subsubsection{Financiamiento}

El Patronato de las Artes es el principal ente gestor y financiero del Museo de Arte de Lima, sin embargo, existen otras entidades privadas y públicas que pueden aportar a que este proyecto se lleve a cabo:

\section{Ente gestor:}

Patronato de Las Artes, principal benefactor y administrador del Museo de Are de Lima y sus talleres artísticos, se encargará del concurso público, aprobación, supervisión y control final de la obra. También, junto con la directiva del Museo de Arte de Lima, seleccionará la muestra museográfica que se expondrá.

\section{Inversión Privada:}

Subastas:

Desde 1996 el MALI lleva a cabo la Subasta Anual de Arte, y a partir del 2007, esta ha sido complementada con una Fiesta de Verano. Ambos eventos sirven para la recaudación de fondos que van directamente al Patronato de las Artes. 
Programa Amigos del MALI (PAM):

Fundado en 1993, el PAM tiene como principal función acercar la cultura y el arte a las personas, y a su vez, recaudar fondos para mantener, conservar y ampliar las instalaciones del Museo. Existen 7 distintos planes de membresía, con distintos aportes anuales, que permiten ser Amigo del MALI.

Programa de Donaciones Corporativas (PDC):

El PDC ofrece 5 categorías en las cuales las empresas pueden colaborar y así obtener beneficios corporativos y para sus empleados. Esta es una de las principales fuentes de ingreso del MALI.

Grupo Centenario:

El MALI está asociado al grupo Centenario, y busca conseguir su financiación a través del programa público "Obras por impuestos".

\section{Inversión Pública:}

\section{Plan COPESCO:}

Es un organismo adscrito al Ministerio de Comercio Exterior y Turismo, que tiene como principal función coordinar, dirigir, ejecutar y supervisar proyectos. Para este proyecto se busca que esta entidad estatal puede aportar un 50\% la inversión total proyectada.

En resumen:

Tabla 7.5

Tipos de inversión en el proyecto

\begin{tabular}{|c|c|}
\hline INVERSIÓN PRIVADA & INVERSIÓN PÚBLICA \\
\hline $50 \%$ & $50 \%$ \\
\hline $\begin{array}{ll}\text { - } & \text { Subastas } \\
\text { - } & \text { PAM } \\
\text { - } & \text { PDC } \\
\text { - } & \text { Grupo Centenario }\end{array}$ & Plan COPESCO \\
\hline
\end{tabular}

Fuente Elaboración propia, 2017

\subsubsection{Presupuesto}

A continuación, se muestran las tablas competentes al proyecto incluido el IGV: 
Tabla 7.6

Cuadro de componentes

PROYECTO AMPLIACIÓN DEL MUSEO DE ARTE DE LIMA

CUADRO DE COMPONENTES

\begin{tabular}{|c|c|c|c|c|}
\hline \multirow{2}{*}{ OBJETIVO } & \multirow{2}{*}{ COMPONENTES } & PARTIDAS & \multicolumn{2}{|c|}{ SUBTOTAL } \\
\hline & & OBRAS PRELIMINARES & $\mathrm{S} /$. & $491,560.59$ \\
\hline \multirow[t]{15}{*}{ FUNDAMENTAL PARA PROYECTO } & AMPLIACIÓN DEL MUSEO & ESTRUCTURAS & $\mathrm{s} /$. & $7,373,408.92$ \\
\hline & & ARQUITECTURA & $\mathrm{s} /$. & $2,457,802.97$ \\
\hline & & ELÉCTRICAS Y SANITARIAS & $\mathrm{s} /$. & $5,734,873.60$ \\
\hline & & OTROS & $\mathrm{s} /$. & $327,707.06$ \\
\hline & TOTAL COSTO DIRECTO DE O & & s/. & $16,385,353.15$ \\
\hline & GASTOS GENER & $10 \%$ & $\mathrm{~s} /$. & $1,638,535.32$ \\
\hline & UTILI & $10 \%$ & S/. & $1,638,535.32$ \\
\hline & SUBTC & & $\mathrm{s} /$. & $19,662,423.78$ \\
\hline & & $18 \%$ & $\mathrm{~s} / \mathrm{s}$ & $3,539,236.28$ \\
\hline & TOTAL DE OBRAS CIV & & s/. & $23,201,660.06$ \\
\hline & & & & \\
\hline & GASTOS DE SUPERVIS & $2 \%$ & $\mathrm{~s} /$. & $464,033.20$ \\
\hline & IMPREVIS & $1 \%$ & $\mathrm{~s} /$. & $232,016.60$ \\
\hline & EXPEDIENTE TÉCI & $3 \%$ & $\mathrm{~s} /$. & $696,049.80$ \\
\hline & \multicolumn{2}{|c|}{ TOTAL } & s/. & $24,593,759.66$ \\
\hline \multirow[t]{15}{*}{ FUNDAMENTAL PARA PROYECTO } & ESTACIONAMIENTOS & OBRAS PRELIMINARES & s/. & $327,707.06$ \\
\hline & & ESTRUCTURAS & s/. & $4,915,605.95$ \\
\hline & & ARQUITECTURA & $\mathrm{s} / \mathrm{s}$ & $1,638,535.32$ \\
\hline & & \multirow{2}{*}{$\begin{array}{l}\text { ELÉCTRICAS Y SANITARIAS } \\
\text { OTROS }\end{array}$} & $\mathrm{s} / \mathrm{.}$ & $3,823,249.07$ \\
\hline & & & $\mathrm{S} / \mathrm{s}$ & $218,471.38$ \\
\hline & \multicolumn{2}{|c|}{ TOTAL COSTO DIRECTO DE OBRA } & s/. & $10,923,568.77$ \\
\hline & GASTOS GENERALES & $10 \%$ & $\mathrm{~s} /$. & $1,092,356.88$ \\
\hline & & $10 \%$ & $\mathrm{~s} /$. & $1,092,356.88$ \\
\hline & \multicolumn{2}{|c|}{ SUBTOTAL } & $\mathrm{s} / \mathrm{.}$ & $13,108,282.52$ \\
\hline & \multicolumn{2}{|c|}{ IGV } & 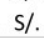 & $2,359,490.85$ \\
\hline & \multicolumn{2}{|c|}{ TOTAL DE OBRAS CIVILES } & s/. & $15,467,773.38$ \\
\hline & \multicolumn{2}{|c|}{ GASTOS DE SUPERVISIÓN } & $\mathrm{s} /$. & $309,355.47$ \\
\hline & IMPREVIS & $1 \%$ & $\mathrm{~s} / \mathrm{.}$ & $154,677.73$ \\
\hline & \multirow{2}{*}{\multicolumn{2}{|c|}{ EXPEDIENTE TÉCNICO }} & 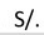 & $464,033.20$ \\
\hline & & & s/. & $16,395,839.78$ \\
\hline
\end{tabular}


Tabla 7.7

Presupuesto de obra de la ampliación

PROYECTO AMPLIACIÓN DEL MUSEO DE ARTE DE LIMA

Presupuesto de obra completo

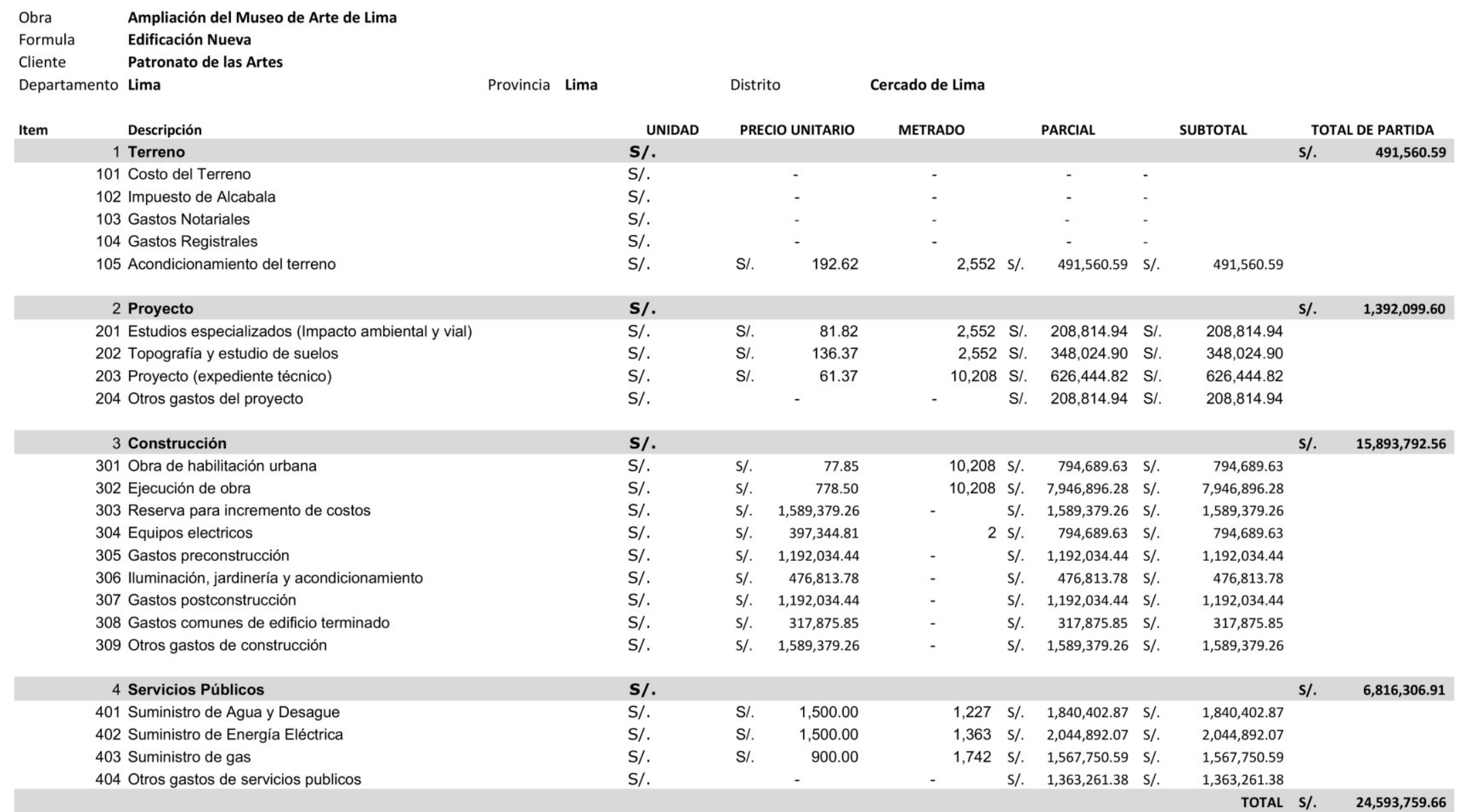

Elaboración propia, 2017 
Tabla 7.8

Presupuesto de obra de los estacionamientos

\section{PROYECTO AMPLIACIÓN DEL MUSEO DE ARTE DE LIMA}

Presupuesto de obra completo

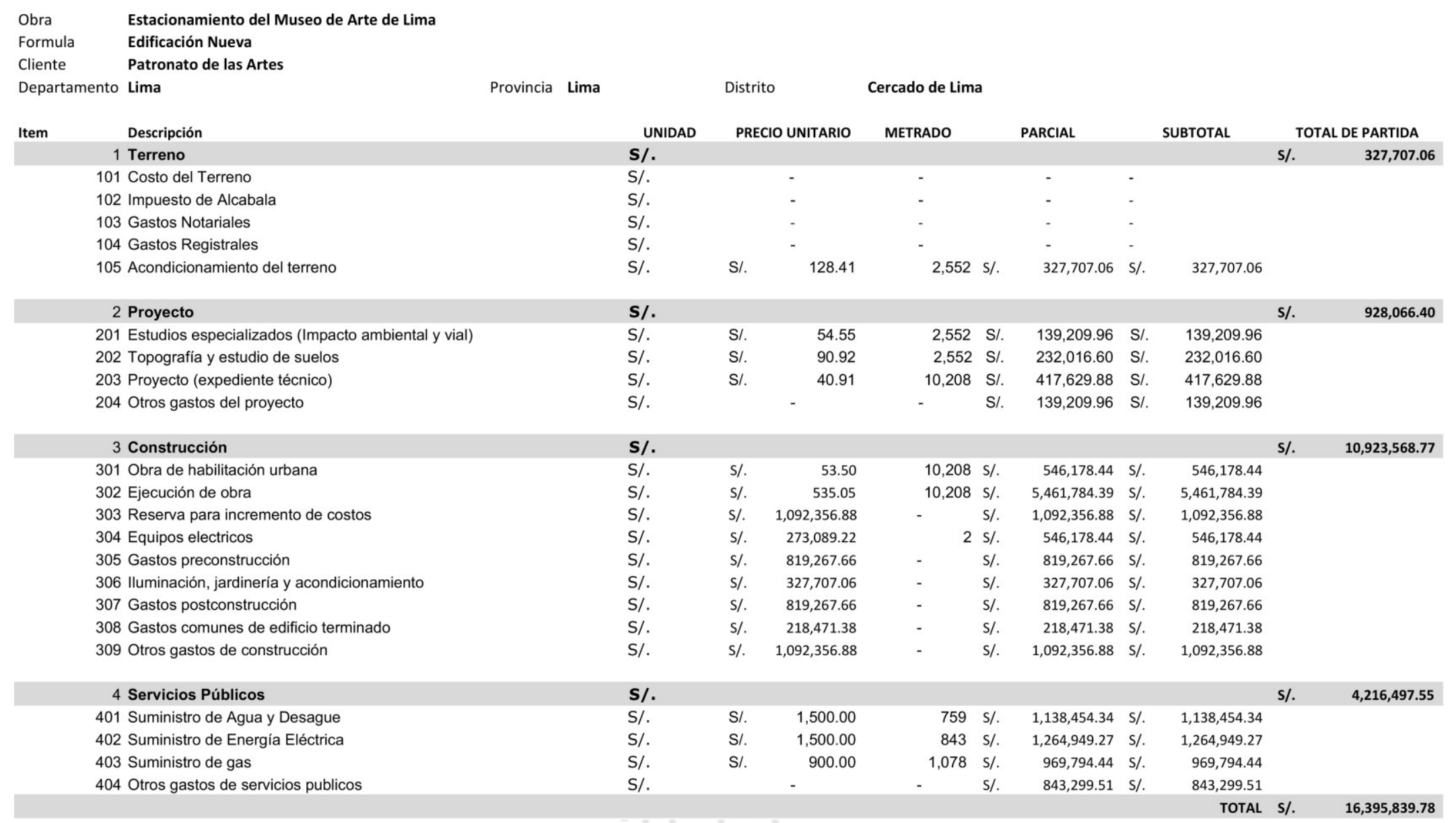

Elaboración propia, 2017 
Tabla 7.9

Valores unitarios

PROYECTO AMPLIACIÓN DEL MUSEO DE ARTE DE LIMA

CUADRO DE COSTOS UNITARIOS

VALORES UNITARIOS OFICIALES DE EDIFICACIONES PARA LA COSTA AL 19 MARZO DE 2017

\begin{tabular}{|c|c|c|c|c|c|c|c|}
\hline \multirow[t]{2}{*}{ CONSTRUCCION } & $\begin{array}{l}\text { ESTRUCTURAS } \\
\text { Muros y columnas (1) }\end{array}$ & Techos (2) & $\begin{array}{l}\text { ACABADOS } \\
\text { Pisos (3) }\end{array}$ & Puertas/ventanas & Revestimiento (5) & Baños (6) & $\begin{array}{l}\text { INST. } \\
\text { I.S. +..E. (T) }\end{array}$ \\
\hline & $\begin{array}{l}\text { Estructuras laminares } \\
\text { curvadas }\end{array}$ & $\begin{array}{l}\text { Aligerado con luces } \\
\text { mayores a } 6 \mathrm{mts} \text {. }\end{array}$ & $\begin{array}{l}\text { Marmol, } \\
\text { porcelanato }\end{array}$ & $\begin{array}{l}\text { Aluminio pesado, } \\
\text { madera fina }\end{array}$ & $\begin{array}{l}\text { Marmol, madera, } \\
\text { baldosa acustica }\end{array}$ & $\begin{array}{l}\text { Baños completos de } \\
\text { Iujo }\end{array}$ & $\begin{array}{l}\text { AA, Agua caliente, ascensor, } \\
\text { bombas, equipo contra } \\
\text { incendio }\end{array}$ \\
\hline \multirow[t]{2}{*}{ A } & 360.06 & 218.69 & 193.13 & Aluminio. 195.41 & $\begin{array}{r}210.62 \\
\text { Marmol, madera, }\end{array}$ & 71.07 & 205.10 \\
\hline & $\begin{array}{l}\text { Columnas y vigas de } \\
\text { concreto armado }\end{array}$ & $\begin{array}{l}\text { Aligerados o losas } \\
\text { inclinadas }\end{array}$ & $\begin{array}{l}\text { Marmol, parquet } \\
\text { fino, ceramica }\end{array}$ & $\begin{array}{l}\text { madera, vidrio } \\
\text { polarizado }\end{array}$ & $\begin{array}{l}\text { enchape en enera, } \\
\text { techos }\end{array}$ & $\begin{array}{l}\text { Baños de color, } \\
\text { mayolica decorativa }\end{array}$ & $\begin{array}{l}\text { Bomba de agua, ascensor, } \\
\text { telefono, agua caliente }\end{array}$ \\
\hline \multirow[t]{2}{*}{ B } & 232.14 & 142.68 & 115.75 & 103.90 & 160.97 & 54.51 & 148.73 \\
\hline & $\begin{array}{l}10 \text { a } 15 \mathrm{~cm} \text { ), ladrillo o } \\
\text { similar con columnas y } \\
\text { vigas de amarre }\end{array}$ & $\begin{array}{l}\text { Aligerado o losas } \\
\text { horizontales }\end{array}$ & $\begin{array}{l}\text { Madera } \\
\text { machihembrada } \\
\text { terazo }\end{array}$ & $\begin{array}{l}\text { Aluminio, madera } \\
\text { normal }\end{array}$ & $\begin{array}{l}\text { Superficie } \\
\text { caravista } \\
\text { encofrado especial }\end{array}$ & $\begin{array}{l}\text { Baños nacionales, } \\
\text { I mayolica de color, }\end{array}$ & Sin ascensor \\
\hline \multirow[t]{2}{*}{ c } & 162.66 & 119.99 & 77.55 & 67.76 & 120.50 & 38.16 & thenction \\
\hline & Ladrillo o similar & $\begin{array}{l}\text { Calamina o } \\
\text { fibracemento sobre } \\
\text { metal }\end{array}$ & $\begin{array}{l}\text { Parquet, } \\
\text { ceramica, loceta }\end{array}$ & $\begin{array}{l}\text { Aluminio, madera } \\
\text { selecta, vidrio } \\
\text { trasparente }\end{array}$ & $\begin{array}{l}\text { Madera, piedra o } \\
\text { material vitrificado }\end{array}$ & $\begin{array}{l}\text { Baños blancos } \\
\text { mayolica blanca }\end{array}$ & $\begin{array}{l}\text { Agua caliente, trifíasica, } \\
\text { telefono }\end{array}$ \\
\hline \multirow[t]{2}{*}{ D } & 157.30 & 76.16 & 68.41 & $\begin{array}{l}59.36 \\
\text { Fierro, madera }\end{array}$ & 92.45 & 20.36 & 59.63 \\
\hline & Adobe, tapial, quincha & $\begin{array}{l}\text { Madera con } \\
\text { impermeabilizante }\end{array}$ & $\begin{array}{l}\text { Parquet de } 2 \mathrm{da} \\
\text { loceta veneciana }\end{array}$ & $\begin{array}{l}\text { selecta, vidrio } \\
\text { trasparente }\end{array}$ & Ladrillo caravista & $\begin{array}{l}\text { Baños sin tina, } \\
\text { mayolica blanca }\end{array}$ & $\begin{array}{l}\text { Agua caliente, monofasica, } \\
\text { telefono }\end{array}$ \\
\hline \multirow[t]{2}{*}{$\mathrm{E}$} & 111.73 & $\begin{array}{r}28.39 \\
\text { Calamina o teja }\end{array}$ & 45.83 & 50.79 & 63.61 & 11.97 & 43.35 \\
\hline & Madera & $\begin{array}{l}\text { Calamina o teja } \\
\text { sobre madera } \\
\text { corriente }\end{array}$ & $\begin{array}{l}\text { Loceta corriente, } \\
\text { canto rodado }\end{array}$ & $\begin{array}{l}\text { Fierro, puertas } \\
\text { contraplacadas }\end{array}$ & $\begin{array}{l}\text { Tarrajeo } \\
\text { frotachado, pintura }\end{array}$ & $\begin{array}{l}\text { Baños sin tina ni } \\
\text { mayolica }\end{array}$ & $\begin{array}{l}\text { Agua fria, monofasica, } \\
\text { empotrada }\end{array}$ \\
\hline \multirow[t]{2}{*}{$\mathrm{F}$} & 83.40 & 15.62 & 31.30 & 38.13 & 44.84 & 8.92 & 23.84 \\
\hline & Pirca con barro & $\begin{array}{l}\text { Madera rustica } 0 \\
\text { caña sobre barro }\end{array}$ & $\begin{array}{l}\text { Vinilico, cemento } \\
\text { coloreado }\end{array}$ & Madera corriente & $\begin{array}{l}\text { Estucado de yeso } \\
\text { o barro, pintura } \\
\text { temple }\end{array}$ & $\begin{array}{l}\text { Sanitarios de fierro } \\
\text { o granito }\end{array}$ & $\begin{array}{l}\text { Agua fria, monofasica, sin } \\
\text { empotrar }\end{array}$ \\
\hline \multirow[t]{2}{*}{ G } & 49.29 & 10.77 & 27.71 & 20.66 & 36.88 & 6.15 & 12.92 \\
\hline & & Sin techo & $\begin{array}{l}\text { Cemento pulido, } \\
\text { ladrillo corriente }\end{array}$ & Rusticas & $\begin{array}{l}\text { Pintura en ladrillo } \\
\text { o similar }\end{array}$ & $\begin{array}{l}\text { Sin aparatos } \\
\text { sanitarios }\end{array}$ & $\begin{array}{l}\text { Sin instalaciones electricas y } \\
\text { sanitarias }\end{array}$ \\
\hline \multirow[t]{2}{*}{$\mathrm{H}$} & - & - & 17.34 & 10.33 & 14.75 & & \\
\hline & & & $\begin{array}{l}\text { Tierra } \\
\text { compactada }\end{array}$ & $\begin{array}{l}\text { Sin puertas ni } \\
\text { ventanas }\end{array}$ & Sin revestimiento & & \\
\hline 1 & & & 3.47 & & & & \\
\hline Tipología del proyecto & 1 & 2 & 3 & 4 & 5 & 6 & 7 \\
\hline & 232.14 & 218.69 & 115.75 & 103.90 & 44.84 & 71.07 & 148.73 \\
\hline
\end{tabular}

Fuente: Elaboración propia, 2017 


\subsubsection{Cronograma de obra}

Una vez obtenido el costo total de la obra, se procede a la elaboración del cronograma de ejecución. En este caso, se dará en dos etapas; la primera, será la ampliación del museo en sí, y la segunda, los estacionamientos frente a la fachada este.

Entonces, se tendrían:

- Etapa 1 - Ampliación (oeste): 3 sótanos y plaza/espacio público

- Etapa 2 - Estacionamiento (este): 3 sótanos y plaza/espacio público

Se proyecta el inicio de ejecución de obra para el año 2018, una vez los trámites correspondientes, financiación y expediente técnico sean resueltos. La finalización de la misma sería para el año 2020, es decir, la obra tomaría aproximadamente dos años.

Primero se empezaría con el acondicionamiento del terreno y excavación complementaria, para luego empezar la construcción de la etapa 1. Es importar anotar que una vez estén listos espacios correspondientes al cuarto de máquinas, estas deberán ser colocadas para poder seguir levantando los pisos superiores.

En segundo, se continuará con la etapa 2, que albergará los estacionamientos y patio de maniobra a nivel.

Sin embargo, cabe mencionar, que una vez finalizada la Etapa 1, a nivel de obra gris, se podrá iniciar paralelamente la Etapa 2 sin perjuicio de las labores en la primera, ya que esta se concentrará en acabados, montaje interior e instalación de obras.

A continuación, de detalla el cronograma en una tabla informativa por mes. 
Tabla 7.10

Cuadro de ejecución de obra y acciones complementarias

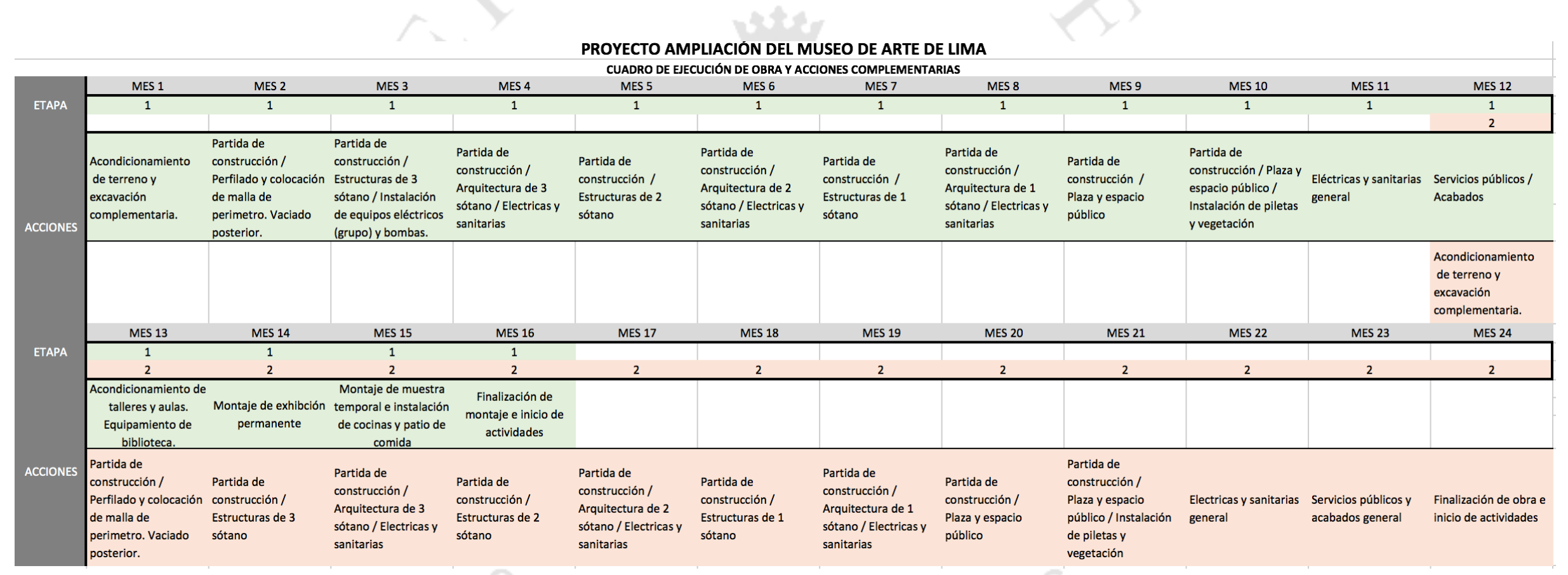

Nota: El cronograma muestra que la contrucción se hará en dos partes. Primero la ampliación del museo, y luego el estacionamiento, en un total de 24 meses. Una vez esté lista la ampliación, está podra ser utilizada.

Fuente: Elaboración propia, 2017 


\subsection{Cronograma de trabajo de investigación}

El cronograma de la investigación se centra exclusivamente en la elaboración y desarrollo del presente documento. Este incluye el tiempo destinado a la búsqueda y recopilación de información de cada sección. Todo el proceso ha contado con asesoría adecuada desde su inicio el 3 de febrero de 2016 al 15 de mayo de 2017

Diagrama 7.2

Cronograma de trabajo de investigación

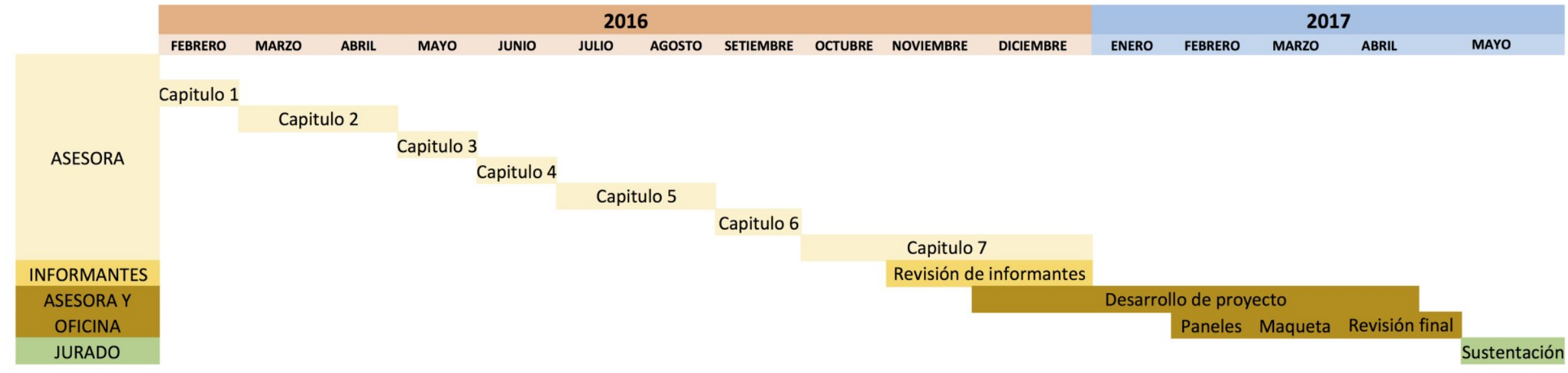

Fuente: Elaboración propia, 2017 


\section{REFERENCIAS}

14a Asamblea General del ICOMOS. (2003). Principios de análisis, conservación y restauración de las estructuras del patrimonio arquitectónico. Zimbawe: ICOMOS.

András, R. (s.f.). Reconstruction - From the Venice Charter to the Charter of Cracow. Conservación, 117-119.

Angelis d'Ossat, G. d. (1983). Restoration of monuments and intervention on old buildings. 3-11.

Architectural Review. (19 de diciembre de 2012). Tipología de Museos. Recuperado el 15 de abril de 2017, de Architectural Review: https://www.architecturalreview.com/Journals/2012/12/18/y/s/s/typology-timeline_2.pdf

Arion, C., \& Lungu, D. (s.f.). Capitulo 5. Recuperado el 05 de mayo de 2015, de Intervention Strategies: www.utcb.ro/prohitech/doc/wp4/WP4_UTCB.pdf

Canziani, J. (08 de diciembre de 2014). Gabriel Ramón Joffré. El neoperuano. Arqueología, estilo nacional y paisaje urbano en Lima, 1910-1940. Recuperado el 09 de mayo de 2017, de Bulletin de l'Institut français d'études andines: http://bifea.revues.org/6002

Davidson, C. (2012). How to Read Buildings. New York, New York, EEUU: Rizzoli.

Gerencia MALI. (15 de abril de 2016).

Graham, B. J., \& Howard, P. (2008). The Ashgate Research Companion to Heritage and Identity. Hampshire, Reino Unido: Ashgate Publishing.

Hernandez, M. (2007). Architecture from Architecture: Encounters between Conservation and Restoration . Future Anterior: Journal of Historic Preservation, History, Theory, and Criticism , 4(2), 62-69.

Historiador del Perú. (9 de diciembre de 2010). El Parque Neptuno. Recuperado el 09 de mayo de 2017, de Historiador del Perú: http://historiadordelperu.blogspot.pe/2010/12/el-parque-neptuno.html 
Instituto Metropolitano para la Planificación. (12 de agosto de 2014). Planos de zonificación de Lima Metropolitana y Ordenanza de Aprobación. Recuperado el 09 de mayo de 2017, de Instituto Metropolitano para la Planificación: http://www.imp.gob.pe/index.php/reajuste-integral-del-plano-de-zonificacionde-lima-metropolitana? $\mathrm{id}=32$

Instituto Nacional de Estadística e Informática. (2014). Estadísticas sobre Cultura. Recuperado el 14 de mayo de 2015, de Instituto Nacional de Estadística e

International Council on Monuments and Sites. (2012). Mission and Vision. Recuperado el 21 de enero de 2017, de International Council on Monuments and Sites: https://www.icomos.org/fr/a-propos-de-licomos/mission-et-vision/licomos-enbref

Joffré, G. R. (2007). El guión de la cirugía urbana: Lima, 1850-1940. Santiago, Chile: Ediciones Universidad Cátolica de Chile. Obtenido de http://200.62.146.19/bibvirtualdata/libros/CSociales/ensayos_ciencias/v1n1/a02. pdf

Jokilehto. (2009). Conservingthe authentic, essays in honour of Jukka Jokilehto. (N. S.P. King, Ed.) Roma, Italia: ICCROM.

Kuon, R. (05 de marzo de 2015). Entrevista académica sobre concervación y museos. (L. C. Osorio, Entrevistador)

Lima Como Vamos. (2014). Cultura. Recuperado el 15 de abril de 2015, de Lima Como Vamos: http://www.limacomovamos.org/cultura/

MALI. (05 de diciembre de 2013). Carrera profesional de Educación Artística y PreMALI. Recuperado el 09 de mayo de 2017, de MALI: http://www.mali.pe/not_detalle.php?id=148

Ministerio de Cultura. (2012). Guía de Museos (2a edición ed.). Lima, Lima, Perú: Dirección de Museos y Bienes Muebles.

Ministerio de Vivienda. (01 de agosto de 2007). Observatorio -2 Zonificación del Cercado de Lima. Recuperado el 20 de mayo de 2015, de Ministerio de Vivienda: http://eudora.vivienda.gob.pe/observatorio/zonificacion/CercadodeLima.pdf 
Ministerio de Vivienda. (2002). Aprueban Reglamento de Organización y Funciones del Ministerio. Recuperado el 15 de abril de 2015, de Ministerio de Vivienda: http://pnsr.vivienda.gob.pe/portal/wp-content/uploads/normas/ds-002-2002.pdf

Ministerio de Vivienda. (2016). Ministerio de Vivienda. Recuperado el 17 de enero de 2017, de Ministerio de Vivienda:

http://www.cultura.gob.pe/es/informacioninstitucional/quienessomos

Museo de Arte de Lima. (10 de noviembre de 2016). Historia del MALI. Recuperado el 21 de enero de 2017, de Museo de Arte de Lima: http://www.mali.pe

Museo del Louvre. (02 de marzo de 2007). Museo del Louvre. Recuperado el 11 de febrero de 2015, de www.pcf-p.com/a/p/8315/s.html

Museo Judio de Berlín. (2011). Museo de Berlín. Recuperado el 11 de febrero de 2015, de Museo de Berlín: www.jmberlin.de/main/Kurzinfo/espanol.php

Museo Judío de Berlín. (2016). El edificio Libeskind. Recuperado el 07 de mayo de 2017, de Museo Judío de Berlín: https://www.jmberlin.de/en/libeskind-building

Neufert, E. (1995). El Arte de Proyectar Arquitectura (14 ed.). (J. Siguan, Trad.) Barcelona, España: Gustavo Gili.

Niglio, O. (23 de mayo de 2013). John Ruskin, Conservation of the Cultural Heritage. Kioto, Japón.

Norberg-Schulz, C. (1975). Existencia, espacio y arquitectura. Barcelona, Catalunya, España: Blume.

Organización de las Naciones Unidas para la Educación, la Ciencia y la Cultura. (21 de mayo de 2010). Instituto Latinoamericano de Museos. Recuperado el 15 de mayo de 2015, de Museos Comprometidos con el Patrimonio Local: http://www.ilam.org/tutorial/Manual_pdf.pdf

Osorio, A. (05 de marzo de 2015). Fotografía digital. Lima, Lima, Perú.

Pevsner, N. (1979). A History of Building Types. Londres, Reino Unido: Thames and Hudson Ltd.

Plazola Cisneros, A. (1977). Enciclopedia de la Arquitectura Plazola. Ciudad de México, México: Noriega. 
Riegl, A. (1903). The Modern Cult of Monuments. Londres, Reino Unido: Oppositions. Recuperado el 15 de 05 de 2015, de Harvard Sites: http://isites.harvard.edu/fs/docs/icb.topic822683.files/Riegl_The\%20Modern\%2 0Cult\%20of\%20Monuments_sm.pdf

Rossi, A. (1995). L'archittetura della citta (3 ed.). Milan, Lombardia, Italia: Citta Studi Edizioni.

Ruskin, J. (2006). Las siete lámparas de la arquitectura. México DF, México: Ediciones Coyocan.

Tshumi, B. (2010). Violence of Architecture. Massachusetts, EEUU: MIT Press.

United Nations Educational, Scientific and Cultural Organization. (2010). Introducing UNESCO. Recuperado el 15 de abril de 2015, de United Nations Educational, Scientific and Cultural Organization: http://es.unesco.org/about-us/introducingunesco

Vásquez, O. (2014). Reglamento Nacional de Edificaciones. Lima, Lima, Perú: Oscar Vasquez SAC.

Viollet-le-Duc, E. E., \& Wethered, C. (1875). On restoration. Orford, Reino Unido: Orford University. 


\section{BIBLIOGRAFÍA}

András, R. (s.f.). Reconstruction - From the Venice Charter to the Charter of Cracow. Conservación, 117-119.

Angelis d'Ossat, G. d. (1983). Restoration of monuments and intervention on old buildings. 3-11.

Arion, C., \& Lungu, D. (s.f.). Capitulo 5. Obtenido de Intervention Strategies: www.utcb.ro/prohitech/doc/wp4/WP4_UTCB.pdf

Banco de Crédito (1992) Oro antiguo. Colección Arte y Tesoros Perú. Lima, Perú. Fondo Editorial del Banco de Crédito del Perú

Banco de Crédito (1994) Los Incas y Tesoros del Perú. Colección Arte y Tesoros Perú. Lima, Perú. Fondo Editorial del Banco de Crédito del Perú

Banco de Crédito (1999) Túcume. Colección Arte y Tesoros Perú. Lima, Perú. Fondo Editorial del Banco de Crédito del Perú

Batres, Milla (1979) Compendio histórico del Perú. Lima, Perú. Colección Milla Batres. Editorial Milla Batres.

Biblioteca Internacional de Literatura Infantil. (s.f.). Biblioteca Internacional de Literatura Infantil. Recuperado el Febrero de 2015, de Biblioteca Internacional de Literatura Infantil: http://www.galinsky.com/buildings/childit/

Davidson, C. (2012). How to Read Buildings. New York, New York, EEUU: Rizzoli.

Editora Nacional (1998) Lima. Los Paseos por la Ciudad y su Historia. Guías Expreso (primera edición) fascículo I. Lima, Perú. Fondo Editorial Nacional S.A.

Gombrich, Ernst H. (2004) Breve historia de la cultura. España. Editorial Peninsula.

Gombrich, Ernst. (1997) Historia del Arte. Madrid, España. Editorial Debate

Hauser, Arnold. (1994) Historia Social de la Literatura y el Arte. Barcelona, España. Editorial Labor

Hernandez, M. (2007). Architecture from Architecture: Encounters between Conservation and Restoration . Future Anterior: Journal of Historic Preservation, History, Theory, and Criticism , 4(2), 62-69. 
Ingo, Walter. (2005) Los maestros de la pintura occidental: una historia del arte en 900 análisis de obras. Berlin, Alemania. Taschen.

Jacques Pi, Jessica (2003) La Estética del románico y el gótico. CDMX, México, Editorial Machado.

Jodidio, P. (2012). 100 Contemporary Architects. Cologne, Alemania: Taschen.

Jodidio, P. (2014). Ando, Complete Works 1975-2014. Cologne, Alemania: Taschen.

Johnson, Paul. (2001) El Renacimiento. Madrid, España. Editorial Mondori.

Lozano Fuentes, José Manuel. (1976) Historia del Arte. CDMX, México, Cía. Editorial Continental.

Museo de Kolumba. (s.f.). Museo de Kolumba. Recuperado el Febrero de 2014, de Museo de Kolumba: http://openbuildings.com/buildings/kolumba/kolumba-museumprofile-38761

Museo del Louvre. (s.f.). Museo del Louvre. Recuperado el febrero de 2015, de www.pcfp.com/a/p/8315/s.html

Museo Judio de Berlín. (s.f.). Museo de Berlín. Recuperado el febrero de 2015, de Museo de Berlín: www.jmberlin.de/main/Kurzinfo/espanol.php

Neufert, E. (1995). El Arte de Proyectar Arquitectura (14 ed.). (J. Siguan, Trad.) Barcelona, España: Gustavo Gili.

Niglio, O. (23 de mayo de 2013). John Ruskin, Conservation of the Cultural Heritage. Kioto, Japón.

Organización de las Naciones Unidas para la Educación, la Ciencia y la Cultura. (15 de mayo de 2015). Instituto Latinoamericano de Museos. Recuperado el 15 de mayo de 2015, de Museos Comprometidos con el Patrimonio Local: http://www.ilam.org/tutorial/Manual_pdf.pdf

Pevsner, N. (1979). A History of Building Types. Londres, Reino Unido: Thames and Hudson Ltd.

Riesel, Joseph J. (2007) Revelaciones: las artes en América Latina, 1492-1820 Lima, Peru. Fondo de Cultura Económica

Rojas Mix, Miguel. (2006) El imaginario: civilización y cultura del siglo XXI. BsAs. Argentina. 1a ed. Ediciones Prometeo 
Ruskin, J. (2006). Las siete lámparas de la arquitectura. México DF, México: Ediciones Coyocan.

Shiff, Richard (2002) Cezanne y el fin del impresionismo: estudio de la teoría, la técnica y la valoración crítica del arte moderno. Madrid, España: A. Machado Libros.

Shiner, Larry (2004) La Invención del arte: la historia cultural. Barcelona, España. Paidós

Tshumi, B. (2010). Violence of Architecture. Massachusetts, EEUU: MIT Press. 


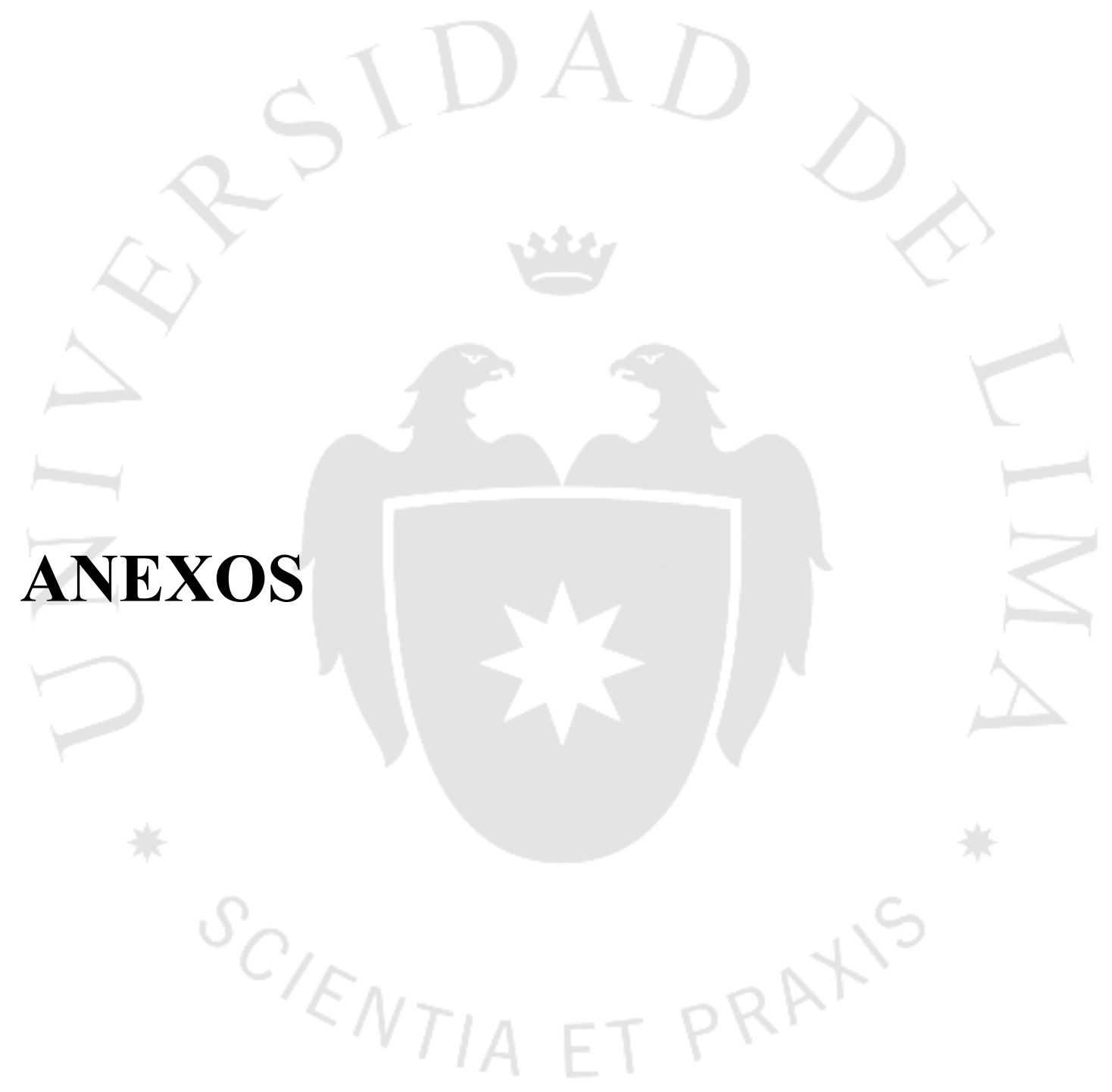


Anexo 1: Carta de Cracovia 


\title{
CARTA DE CRACOVIA 2000 ${ }^{1}$
}

\section{PRINCIPIOS PARA LA CONSERVACIÓN Y RESTAURACIÓN DEL PATRIMONIO CONSTRUIDO}

\begin{abstract}
Reconociendo la contribución de particulares e instituciones que, en el transcurso de tres años, han participado en la preparación de la Conferencia Internacional sobre Conservación "Cracovia 2000" y en su Sesión Plenaria "Patrimonio Cultural como fundamento del Desarrollo de la Civilización",
\end{abstract}

Nosotros, los participantes en la Conferencia Internacional sobre Conservación "Cracovia 2000", conscientes de los profundos significados asociados con el patrimonio cultural, sometemos los siguientes principios a los responsables de patrimonio como una pauta para realizar los esfuerzos necesarios para salvaguardar tales bienes.

\section{PREÁMBULO}

Actuando en el espíritu de la Carta de Venecia, tomando nota de las recomendaciones internacionales e impulsados por el proceso de unificación Europea, a la entrada del nuevo milenio, somos conscientes de vivir dentro de un marco, en el cual las identidades, en un contexto cada vez más amplio, se personalizan y se hacen más diversas.

La Europa actual se caracteriza por la diversidad cultural y por tanto por la pluralidad de valores fundamentales relacionados con los bienes muebles, inmuebles y el patrimonio intelectual, con diferentes significados asociados con todo ello y, consecuentemente, también con conflictos de intereses. Esto obliga a todos aquellos responsables de salvaguardar el patrimonio cultural a prestar cada vez más atención a los problemas y las alternativas a las que se enfrentan para conseguir estos objetivos.

Cada comunidad, teniendo en cuenta su memoria colectiva y consciente de su pasado, es responsable de la identificación, así como de la gestión de su patrimonio. Los elementos individuales de este patrimonio son portadores de muchos valores, los cuales pueden cambiar en el tiempo. Esta variabilidad de valores específicos en los elementos define la particularidad de cada patrimonio. A causa de este proceso de cambio, cada comunidad desarrolla una conciencia y un conocimiento de la necesidad de cuidar los valores propios de su patrimonio.

Este patrimonio no puede ser definido de un modo unívoco y estable. Sólo se puede indicar la dirección en la cual puede ser identificado. La pluralidad social implica una gran diversidad en los conceptos de patrimonio concebidos por la comunidad entera; al mismo tiempo los instrumentos y métodos desarrollados para la preservación correcta deben ser adecuados a la situación cambiante actual, que es sujeto de un proceso de evolución continua. El contexto particular de elección de estos valores requiere la preparación de un proyecto de conservación a través de una serie de decisiones de elección crítica. Todo esto debería ser materializado en un proyecto de restauración de acuerdo con unos criterios técnicos y organizativos.

\footnotetext{
${ }^{1}$ Versión española del Instituto Español de Arquitectura (Universidad de Valladolid), Javier

Rivera Blanco y Salvador Pérez Arroyo. Miembros del Comité Científico de la "Conferencia Internacional Cracovia 2000".
} 
Conscientes de los profundos valores de la Carta de Venecia y trabajando hacia los mismos objetivos, proponemos para nuestros días los siguientes principios para la conservación y restauración del patrimonio edificado.

\section{OBJETIVOS Y MÉTODOS}

1. El patrimonio arquitectónico, urbano y paisajístico, así como los elementos que lo componen, son el resultado de una identificación con varios momentos asociados a la historia y a sus contextos socioculturales. La conservación de este patrimonio es nuestro objetivo. La conservación puede ser realizada mediante diferentes tipos de intervenciones como son el control medioambiental, mantenimiento, reparación, restauración, renovación y rehabilitación. Cualquier intervención implica decisiones, selecciones y responsabilidades relacionadas con el patrimonio entero, también con aquellas partes que no tienen un significado específico hoy, pero podrían tenerlo en el futuro.

2. El mantenimiento y la reparación son una parte fundamental del proceso de conservación del patrimonio. Estas acciones tienen que ser organizadas con una investigación sistemática, inspección, control, seguimiento y pruebas. Hay que informar y prever el posible deterioro, y tomar las adecuadas medidas preventivas.

3. La conservación del patrimonio edificado es llevada a cabo según el proyecto de restauración, que incluye la estrategia para su conservación a largo plazo. Este "proyecto de restauración" debería basarse en una gama de opciones técnicas apropiadas y organizadas en un proceso cognitivo que integre la recogida de información y el conocimiento profundo del edificio y/o del emplazamiento. Este proceso incluye el estudio estructural, análisis gráficos y de magnitudes y la identificación del significado histórico, artístico y sociocultural. En el proyecto de restauración deben participar todas las disciplinas pertinentes y la coordinación deberá ser llevada a cabo por una persona cualificada y bien formada en la conservación y restauración.

4. Debe evitarse la reconstrucción en "el estilo del edificio" de partes enteras del mismo. La reconstrucción de partes muy limitadas con un significado arquitectónico puede ser excepcionalmente aceptada a condición de que esta se base en una documentación precisa e indiscutible. Si se necesita, para el adecuado uso del edificio, la incorporación de partes espaciales y funcionales más extensas, debe reflejarse en ellas el lenguaje de la arquitectura actual. La reconstrucción de un edificio en su totalidad, destruido por un conflicto armado o por desastres naturales, es solo aceptable si existen motivos sociales o culturales excepcionales que están relacionados con la identidad de la comunidad entera.

\section{DIFERENTES CLASES DE PATRIMONIO EDIFICADO}

5. Cualquier intervención que afecte al patrimonio arqueológico, debido a su vulnerabilidad, debe estar estrictamente relacionada con su entorno, territorio y paisaje. Los aspectos destructivos de la excavación deben reducirse tanto como sea posible. En cada excavación, el trabajo arqueológico debe ser totalmente documentado.

Como en el resto de los casos, los trabajos de conservación de hallazgos arqueológicos deben basarse en el principio de mínima intervención. Estos deben ser realizados por profesionales y la metodología y las técnicas usadas deben ser controladas de forma estricta.

En la protección y preservación pública de los sitios arqueológicos, se deben potenciar el uso de modernas tecnologías, bancos de datos, sistemas de información y presentaciones virtuales.

6. La intención de la conservación de edificios históricos y monumentos, estén estos en contextos rurales o urbanos, es mantener su autenticidad e integridad, incluyendo los 
espacios internos, mobiliario y decoración de acuerdo con su conformación original. Semejante conservación requiere un apropiado "proyecto de restauración" que defina los métodos y los objetivos. En muchos casos, esto además requiere un uso apropiado, compatible con el espacio y significado existente. Las obras en edificios históricos deben prestar una atención total a todos los periodos históricos presentes.

7. La decoración arquitectónica, esculturas y elementos artísticos que son una parte integrada del patrimonio construido deben ser preservados mediante un proyecto específico vinculado con el proyecto general. Esto supone que el restaurador tiene el conocimiento y la formación adecuados además de la capacidad cultural, técnica y práctica para interpretar los diferentes análisis de los campos artísticos específicos. El proyecto de restauración debe garantizar un acercamiento correcto a la conservación del conjunto del entorno y del ambiente, de la decoración y de la escultura, respetando los oficios y artesanía tradicionales del edificio y su necesaria integración como una parte sustancial del patrimonio construido.

8. Las ciudades históricas y los pueblos en su contexto territorial, representan una parte esencial de nuestro patrimonio universal y deben ser vistos como un todo, con las estructuras, espacios y factores humanos normalmente presentes en el proceso de continua evolución y cambio. Esto implica a todos los sectores de la población, y requiere un proceso de planificación integrado, consistente en una amplia gama de intervenciones. La conservación en el contexto urbano se puede referir a conjuntos de edificios y espacios abiertos, que son parte de amplias áreas urbanas, o de pequeños asentamientos rurales o urbanos, con otros valores intangibles. En este contexto, la intervención consiste en considerar siempre a la ciudad en su conjunto morfológico, funcional y estructural, como parte del territorio, del medio ambiente y del paisaje circundante. Los edificios que constituyen las áreas históricas pueden no tener ellos mismos un valor arquitectónico especial, pero deben ser salvaguardados como elementos del conjunto por su unidad orgánica, dimensiones particulares y características técnicas, espaciales, decorativas y cromáticas insustituibles en la unidad orgánica de la ciudad.

El proyecto de restauración del pueblo o la ciudad histórica debe anticiparse la gestión del cambio, además de verificar la sostenibilidad de las opciones seleccionadas, conectando las cuestiones de patrimonio con los aspectos económicos y sociales. Aparte de obtener conocimiento de la estructura general, se exige la necesidad del estudio de las fuerzas e influencias de cambio y de las herramientas necesarias para el proceso de gestión. El proyecto de restauración para áreas históricas contempla los edificios de la estructura urbana en su doble función: a) los elementos que definen los espacios de la ciudad dentro de su forma urbana y b) los valores espaciales internos que son una parte esencial del edificio.

9. Los paisajes como patrimonio cultural son el resultado y el reflejo de una interacción prolongada a través de diferentes sociedades entre el hombre, la naturaleza y el medio ambiente físico. Son el testimonio de la relación del desarrollo de comunidades, individuos y su medio ambiente. En este contexto su conservación, preservación y desarrollo se centra en los aspectos humanos y naturales, integrando valores materiales e intangibles. Es importante comprender y respetar el carácter de los paisajes, y aplicar las adecuadas leyes y normas para armonizar la funcionalidad territorial con los valores esenciales. En muchas sociedades, los paisajes están relacionados e influenciados históricamente por los territorios urbanos próximos.

La integración de paisajes con valores culturales, el desarrollo sostenible de regiones y localidades con actividades ecológicas, así como el medio ambiente natural, requiere conciencia y entendimiento de las relaciones en el tiempo. Esto implica establecer vínculos con el medio ambiente construido de la metrópoli, la ciudad y el municipio.

La conservación integrada de paisajes arqueológicos y estáticos con el desarrollo de paisajes muy dinámicos, implica la consideración de valores sociales, culturales y estéticos. 
10. Las técnicas de conservación o protección deben estar estrictamente vinculadas a la investigación pluridisciplinar científica sobre materiales y tecnologías usadas para la construcción, reparación y/o restauración del patrimonio edificado. La intervención elegida debe respetar la función original y asegurar la compatibilidad con los materiales y las estructuras existentes, así como con los valores arquitectónicos. Cualquier material y tecnología nuevos deben ser probados rigurosamente, comparados y adecuados a la necesidad real de la conservación. Cuando la aplicación "in situ" de nuevas tecnologías puede ser relevante para el mantenimiento de la fábrica original, estas deben ser continuamente controladas teniendo en cuenta los resultados obtenidos, su comportamiento posterior y la posibilidad de una eventual reversibilidad.

Se deberá estimular el conocimiento de los materiales tradicionales y de sus antiguas técnicas así como su apropiado mantenimiento en el contexto de nuestra sociedad contemporánea, siendo ellos mismos componentes importantes del patrimonio cultural.

\section{PLANIFICACIÓN Y GESTIÓN}

11. La gestión del proceso de cambio, transformación y desarrollo de las ciudades históricas y del patrimonio cultural en general, consiste en el control de las dinámicas de cambio, de las opciones y de los resultados. Debe ponerse particular atención a la optimización de los costes del proceso. Como parte esencial de este proceso, es necesario identificar los riesgos a los que el patrimonio puede verse sujeto incluso en casos excepcionales, anticipar los sistemas apropiados de prevención, y crear planes de actuación de emergencia. El turismo cultural, aceptando sus aspectos positivos en la economía local, debe ser considerado como un riesgo.

La conservación del patrimonio cultural debe ser una parte integral de los procesos de planificación y gestión de una comunidad, y puede contribuir al desarrollo sostenible, cualitativo, económico y social de esta comunidad.

12. La pluralidad de valores del patrimonio y la diversidad de intereses requiere una estructura de comunicación que permita, además de a los especialistas y administradores, una participación efectiva de los habitantes en el proceso. Es responsabilidad de las comunidades establecer los métodos y estructuras apropiados para asegurar la participación verdadera de individuos e instituciones en el proceso de decisión.

\section{FORMACIÓN Y EDUCACIÓN}

13. La formación y la educación en cuestiones de patrimonio cultural exigen la participación social y la integración dentro de sistemas de educación nacionales en todos los niveles. La complejidad de un proyecto de restauración, o de cualquier otra intervención de conservación que supone aspectos históricos, técnicos, culturales y económicos requiere el nombramiento de un responsable bien formado y competente.

La educación de los conservadores debe ser interdisciplinar e incluir un estudio preciso de la historia de la arquitectura, la teoría y las técnicas de conservación. Esto debería asegurar la cualificación necesaria para resolver problemas de investigación, para llevar a cabo las intervenciones de conservación y restauración de una manera profesional y responsable.

Los profesionales y técnicos en la disciplina de conservación deben conocer las metodologías adecuadas y las técnicas necesarias y ser conscientes del debate actual sobre teorías y políticas de conservación.

La calidad de los oficios y el trabajo técnico durante los proyectos de restauración debe también ser reforzada con una mejor formación profesional de los operarios involucrados. 


\section{MEDIDAS LEGALES}

14. La protección y conservación del patrimonio edificado será más eficaces si se llevan a cabo conjuntamente acciones legales y administrativas. Estas deben estar dirigidas a asegurar que el trabajo de conservación se confíe o, esté en todo caso, bajo la supervisión, de profesionales de la conservación.

Las medidas legales deben también asegurar un periodo de experiencia práctica en un programa estructurado. Debe dedicarse una particular atención con el control de profesionales de la conservación a los recién formados en este campo que en breve podrán acceder a la práctica independiente.

\section{ANEXO. DEFINICIONES}

El comité de redacción de esta "Carta de Cracovia" usó los siguientes conceptos terminológicos.

a. Patrimonio: Patrimonio es el conjunto de las obras del hombre en las cuales una comunidad reconoce sus valores específicos y particulares y con los cuales se identifica. La identificación y la especificación del patrimonio es por tanto un proceso relacionado con la elección de valores.

b. Monumento: El monumento es una entidad identificada por su valor y que forma un soporte de la memoria. En él, la memoria reconoce aspectos relevantes que guardan relación con actos y pensamientos humanos, asociados al curso de la historia y todavía accesibles a nosotros.

c. Autenticidad: Significa la suma de características sustanciales, históricamente determinadas: del original hasta el estado actual, como resultado de las varias transformaciones que han ocurrido en el tiempo.

d. Identidad: Se entiende como la referencia común de valores presentes generados en la esfera de una comunidad y los valores pasados identificados en la autenticidad del monumento.

e. Conservación: Conservación es el conjunto de actitudes de una comunidad dirigidas a hacer que el patrimonio y sus monumentos perduren. La conservación es llevada a cabo con respecto al significado de la identidad del monumento y de sus valores asociados.

f. Restauración: La restauración es una intervención dirigida sobre un bien patrimonial, cuyo objetivo es la conservación de su autenticidad y su apropiación por la comunidad.

g. Proyecto de restauración: El proyecto, resultado de la elección de políticas de conservación, es el proceso a través del cual la conservación del patrimonio edificado y del paisaje es llevada a cabo.

\section{Redacción dirigida por:}

Comité de redacción - A. Kadluczka (Polonia), G. Cristinelli (Italia), M. Zádor (Hungría).

Comité de redacción de los Directores de Áreas: Giuseppe Cristinelli (Italia), Sherban Cantacuzino (Inglaterra), Javier Rivera Blanco (España), Jacek Purchla, J. Louis Luxen (Bélgica - Francia), Tatiana Kirova (Italia), Zbigniew Kobylinski (Polonia), Andrzej Kadluczka (Polonia), André De Naeyer (Bélgica), Tamas Fejerdy (Hungría), Salvador Pérez Arroyo (España), Andrzej Michalowski (Polonia), Robert de Jong (Holanda), Mihály Zádor (Hungría), M. Peste (Alemania), Manfred Wehdorn (Austria), Ireneusz Pluska 
(Polonia), Jan Schubert, Mario Docci (Italia), Herb Stovel (Canadá - Italia), Jukka Jokiletho (Finlandia - Italia), Ingval Maxwell (Escocia), Alessandra Melucco (Italia). 
Anexo 2: Principios de análisis, conservación y restauración ICOMOS 


\title{
PRINCIPIOS PARA EL ANÁLISIS, CONSERVACIÓN Y RESTAURACIÓN DE LAS ESTRUCTURAS DEL PATRIMONIO ARQUITECTÓNICO (2003)
}

\author{
Ratificada por la 14a Asamblea General del ICOMOS, en Victoria Falls, \\ Zimbabwe, Octubre de 2003
}

\section{PRINCIPIOS}

\section{FINALIDAD DE ESTE DOCUMENTO}

Las estructuras del patrimonio arquitectónico, tanto por su naturaleza como por su historia (en lo que se refiere al material y a su ensamblaje), están sometidas a una serie de dificultades de diagnóstico y restauración, que limitan la aplicación de las disposiciones normativas y las pautas vigentes en el ámbito de la construcción. Ello hace tan deseable como necesario formular unas recomendaciones que garanticen la aplicación de unos métodos racionales de análisis y restauración, adecuados a cada contexto cultural.

Las presentes Recomendaciones tratan de servir a todos aquellos a quienes atañen los problemas de la conservación y la restauración, aunque en ningún modo pueden reemplazar los conocimientos específicos extraídos de textos de contenido cultural y científico.

El contenido íntegro de estas Recomendaciones se recoge en un documento dividido en dos secciones: la titulada Principios, donde se plantean los conceptos básicos de conservación, y la titulada Directrices, donde se proponen las reglas y los métodos que deberían seguirse por los que intervienen en ambas actividades. Sólo los Principios han alcanzado la categoría de documento oficialmente aprobado y ratificado por ICOMOS.

Las Directrices se presentan en inglés en un documento aparte.

\section{PRINCIPIOS}

\section{CRITERIOS GENERALES}

1.1 La conservación, consolidación y restauración del patrimonio arquitectónico requieren un tratamiento multidisciplinar.

1.2 El valor y la autenticidad del patrimonio arquitectónico no pueden fundamentarse en criterios predeterminados porque el respeto que merecen todas las culturas requiere que el patrimonio material de cada una de ellas sea considerado dentro del contexto cultural al que pertenece.

1.3 El valor del patrimonio arquitectónico no reside únicamente en su aspecto externo, sino también en la integridad de todos sus componentes como producto genuino de la tecnología constructiva propia de su época. De forma particular, el vaciado de sus estructuras internas para mantener solamente las fachadas no responde a los criterios de conservación. 
1.4 Cuando se trate de realizar un cambio de uso o funcionalidad, han de tenerse en cuenta, de manera rigurosa, todas las exigencias de la conservación y las condiciones de seguridad.

1.5 La restauración de estructuras, por lo que se refiere al Patrimonio Arquitectónico, no es un fin en sí misma, sino un medio al servicio de un fin que no es otro que el elemento construido en su conjunto.

1.6 Las peculiaridades que ofrecen las estructuras arquitectónicas, con su compleja historia, requieren que los estudios y propuestas se organicen en fases sucesivas y bien definidas, similares a las que se emplean en medicina: Anamnesis, diagnosis, terapia y control, aplicados a la correspondiente búsqueda de datos reveladores e información; determinación de las causas de deterioro y degradación; elección de las medidas correctoras, y control de la eficacia de las intervenciones. Para conseguir un equilibrio óptimo entre el coste y los resultados y producir el mínimo impacto posible en el patrimonio arquitectónico, utilizando los fondos disponibles de una manera racional, se hace normalmente necesario repetir estas fases de estudio dentro de un proceso continuado.

1.7 No deben emprenderse actuaciones sin sopesar antes sus posibles beneficios y perjuicios sobre el patrimonio arquitectónico, excepto cuando se requieran medidas urgentes de protección para evitar la ruina inminente de las estructuras (por ejemplo, tras los daños causados por un seísmo); no obstante, se tratará de evitar que tales medidas urgentes produzcan una modificación irreversible de las estructuras.

\section{INVESTIGACIÓN Y DIAGNÓSTICO}

2.1 Habitualmente, un equipo pluridisciplinario, cuya composición vendrá determinada por el tipo y la envergadura del problema, debe trabajar conjuntamente desde las primeras fases del proyecto, así como en el examen inicial del lugar y en la preparación del programa de investigación.

2.2 En primer lugar, la recopilación y el tratamiento de los datos y la información deben llevarse a cabo de forma equilibrada, prudente y ponderada, con el fin de establecer un plan integral de actuación proporcionado a los problemas reales de las estructuras.

2.3 La práctica de la conservación requiere un conocimiento exhaustivo de las características de la estructura y los materiales. Es fundamental disponer de información sobre la estructura en su estado original y en sus primeras etapas, las técnicas que se emplearon en la construcción, las alteraciones sufridas y sus efectos, los fenómenos que se han producido $y$, por último, sobre su estado actual.

2.4 En los lugares con vestigios arqueológicos pueden plantearse problemas específicos, dado que las estructuras deben estabilizarse al mismo tiempo que se realiza la excavación, cuando el conocimiento todavía no es completo. Los comportamientos estructurales en una construcción puesta al descubierto por este tipo de obras pueden ser completamente diferentes a los de otra que no se ha mantenido oculta. La soluciones urgentes que sea preciso adoptar para estabilizar una estructura a medida que se procede a su excavación, no deberán poner en peligro el significado integral de la edificación, tanto por lo que se refiere a su forma como a su uso.

2.5 El diagnóstico debe apoyarse en métodos de investigación histórica de carácter cualitativo y cuantitativo; los primeros, han de basarse principalmente en la observación de los daños estructurales y la degradación material, así como en la investigación histórica y arqueológica propiamente dicha, y los segundos, fundamentalmente en pruebas de los materiales y la estructura, en la supervisión continua de los datos y en el análisis estructural.

2.6 Antes de tomar la decisión de llevar a cabo una intervención que afecte a las estructuras, es indispensable determinar cuáles son las causas de los daños y 
la degradación, y después, evaluar el grado de seguridad que dichas estructuras ofrecen.

2.7 En la evaluación sobre seguridad, que constituye la última fase de la diagnosis, y en la que se determina la necesidad de aplicar un tratamiento, se deben estudiar conjuntamente las conclusiones de los análisis cualitativos y cuantitativos: la observación directa, la investigación histórica, el análisis estructural y, en su caso, los resultados experimentales y las pruebas que se hayan realizado.

2.8 A menudo, la aplicación de coeficientes de seguridad concebidos para obras nuevas conduce a la adopción de medidas que resultan excesivas, e incluso imposibles de llevar a la práctica. En estos casos, puede estar justificado recurrir a otras soluciones respecto a la seguridad, si así lo aconsejan unos análisis específicos y otras consideraciones aplicables al caso.

2.9 Todos los aspectos relativos a la información obtenida, así como el diagnóstico, incluyendo en éste la evaluación de la seguridad, y la decisión de intervenir, deberán recogerse, de forma descriptiva, en una "MEMORIA INFORMATIVA".

\section{MEDIDAS CORRECTORAS Y DE CONTROL}

3.1 La terapia debe estar dirigida a las raíces del problema más que a los síntomas.

3.2 La mejor terapia es la aplicación de medidas de mantenimiento de índole preventiva.

3.3 La evaluación de la seguridad y un buen entendimiento del significado de la estructura deben constituir las bases de las medidas de conservación y consolidación.

3.4 No debe emprenderse acción alguna sin haber comprobado antes que resulta indispensable.

3.5 Cada intervención debe ser proporcional a los objetivos de seguridad previamente establecidos, y limitarse al mínimo indispensable para garantizar la seguridad y la perdurabilidad del bien con el menor daño posible a los valores del patrimonio.

3.6 El proyecto de intervención deberá basarse en una comprensión clara de la clase de factores que causaron el daño y la degradación, así como de los que hayan de tenerse en cuenta para analizar la estructura tras la intervención, puesto que el proyecto debe realizarse en función de todos ellos.

3.7 La elección entre técnicas "tradicionales" e "innovadoras" debe sopesarse caso por caso, dando siempre preferencia a las que produzcan un efecto de invasión menor y resulten más compatibles con los valores del patrimonio cultural, sin olvidar nunca cumplir las exigencias impuestas por la seguridad y la perdurabilidad.

3.8 En ocasiones, la dificultad de evaluar el grado real de seguridad y los posibles resultados positivos de las intervenciones puede hacer recomendable emplear un "método de observación" consistente, por ejemplo, en una actuación escalonada que se inicie con una intervención de baja intensidad, de tal forma que permita ir adoptando una serie de medidas complementarias o correctoras.

3.9 Siempre que sea posible, las medidas que se adopten deben ser "reversibles", es decir, que se puedan eliminar y sustituir por otras más adecuadas y acordes a los conocimientos que se vayan adquiriendo. En el caso de que las intervenciones practicadas no sean completamente reversibles, al menos no deberán limitar la posible ejecución de otras posteriores.

3.10 Deben determinarse todas las características de los materiales (especialmente cuando son nuevos) que vayan a utilizarse en una obra de restauración, así como su compatibilidad con los existentes. En ese estudio deben incluirse los impactos a largo plazo, a fin de evitar efectos secundarios no deseables. 
3.11 No deben destruirse los elementos diferenciadores que caracterizaban a la edificación y su entorno en su estado original o en el correspondiente a las etapas más antiguas.

3.12 Cada intervención debe respetar, en la medida de lo posible, el concepto, las técnicas y los valores históricos de la configuración primigenia de la estructura, así como de sus etapas más tempranas, y debe dejar evidencias que puedan ser reconocidas en el futuro.

3.13 La intervención debe responder a un plan integral de conjunto que tenga debidamente en cuenta los diferentes aspectos de la arquitectura, la estructura, las instalaciones y la funcionalidad.

3.14 Deberá evitarse, siempre que sea posible, la eliminación o alteración de cualquier material de naturaleza histórica, o de elementos que presenten rasgos arquitectónicos de carácter distintivo.

3.15 Las estructuras arquitectónicas deterioradas deben ser reparadas, y no sustituidas, siempre que resulte factible.

3.16 Deberán mantenerse las imperfecciones y alteraciones que se hayan convertido en parte de la historia de la edificación, siempre que no atenten contra las exigencias de la seguridad.

3.17 Sólo se debe recurrir a la alternativa de desmontar y volver a montar los elementos cuando así lo exija la propia naturaleza de los materiales y siempre que su conservación por cualquier otro medio sea imposible o incluso perjudicial.

3.18 Los sistemas de protección provisional utilizados durante la intervención deben servir a su propósito y función sin causar perjuicios a los valores patrimoniales.

3.19 Cualquier propuesta de intervención debe ir acompañada de un programa de control que, en la medida de lo posible, deberá llevarse a cabo mientras se ejecuta la obra.

3.20 No deben autorizarse aquellas medidas que no sean susceptibles de control en el transcurso de su ejecución.

3.21 Durante la intervención, y después de ésta, deben efectuarse unas comprobaciones y una supervisión que permitan cerciorarse de la eficacia de los resultados.

3.22 Todas las actividades de comprobación y supervisión deben registrarse documentalmente y conservarse como parte de la historia de la construcción. 
Anexo 3: Carta de Venecia 
1964 - Carta de Venecia - ICOMOS

\section{CARTA INTERNACIÓNAL SOBRE LA CONSERVACIÓN Y LA RESTAURACIÓN DE MONUMENTOS Y DE CONJUNTOS HISTÓRICO-ARTÍSTICOS}

II Congreso Internacional de Arquitectos y Técnicos de Monumentos Históricos, Venecia 1964 Aprobada por ICOMOS en 1965

"Cargados de un mensoje espiritual del pasado, las obras monumentales de los pueblos continúon siendo en lo vido presente el testimonio vivo do sus tradiciones seculares. Lo humanidad, que cada dia toma conciencia de la unidad de los valores humanos, los considera como un patrimonio comủn, y de cara a las generaciones futuras, se reconoce solidariomente responsable de su salvaguardo. Debe transmitirlos en toda la riqueza de su autenticidod.

Por lo tanto, es esencial que los principios que deben presidir la conservación y la restauración de los monumentos sean establecidos de común y formulados en un plan internacional dejando que cada nación cuide de asegurar su aplicación en el marco de su propia cultura y de sus tradiciones.

Dando una primera forma a estos principios fundamentales, la Carta de Atenas de 1931 ha contribuido al desarrollo de un vosto on los documentos nacionales, en la actividad del ICOM y do la UNESCO y en la creación, por en los documentos nacionales, en la actividad del ICOM y do la UNESCO y en la creación, por
esta última, de un Centro internacional de estudios para la conservación de los bienes culturales esta ültima, de un Centro internacional de estudios para la conservación de los bienes culturales.
La sensibilidad y el espiritu crítico se han vertido sobre problemas cada vez más complejos y más 5 utiles; también ha llegado el momento de volver a examinar los principios de lo Carta a fin de profundizar en ellos $y$ de ensanchar su contenido en un nuevo documento. En consecuencic, III Congreso Internacionat de Arquirectos y de Téricos de Monumentos Históricos reunido en Verecia del 25 ol 31 de mcyo de 1964 , ho aprobado el siguiente texto

\section{Definiciones}

Articulo $1^{\text {" }}$ - La noción de monumento histórico comprende la creaciốn arquitectónica cislada asi como el coniunto urbeno o rurcl que dá testimonio de una civilizoción particulor, de ima evolución significativa, o de un acontecimiento histórice. Se refiere no sólo a las grandes crecciones sino también a las obros modestas que han adquirido con el tiempo una sifanificación cultural.

Artículo $2^{\circ}$ - La conservación y restauración de monumentos constituye una disciplina que obarca todas las ciencias y todas las técricas que puedan contribuir al estudio y la salvaguarda del patrimonio monumenta.

Artículo $3^{\circ}$ - La conservación y restauración de monumentos tiende a salvaguardar tanto la obro de orte como el testimonio histórico.

\section{Conservación}

Artículo $4^{\circ}$ - La conservación de monumentos implica primeramente la constancic en su mantenimiento.

Artículo $5^{\circ}$ - Lo conservoción de monumentos siempre resulta favorecida por su dedicación o una función útil o la sociedad; tal dedicación es por supuesto deseable pero no puede alterar la ordenación o decoración de los edificios. Dentro de estos limites es donde se debe concebir y autorizar los acondicionamientos exigidos por la evolución de los usos y costumbres.

Articulo $6^{\circ}$ - La conservación de un monumento implica la de un marco a su escala. Cuando el marco tradicional subsiste, éste será conservado, y toda construcción nuevo, toda destrucción y cualquier arreglo que pudiera alterar los relaciones entre los volúmenes y los colores, será desechoda.

Artículo $7^{\circ}-E$ monumento es inseparable de la historia de que es testigo y del lugar en el que está ubicado. En consecuencia, el desplazamiento de todo o parte de un monumento no puede ser consentido nada más que cuando la salvaguarda del monumento lo exiija o cuando razones de un gran interés nocional o internacional lo justifiquen.

Artículo $8^{\circ}$ - Los elementos de escultura, pintura o decoración que son parte integrante de un monumento sólo pueden ser separados cuando esta medida sea la única viable para asegurar su conservación.

\section{Restauración}

Articulo 9. La restauración es una operación que debe tener un carácter excepcional. Tiene como fin conservar y revelar los valores estéticos e históricos del monumento y se fundamenta en el respeto a la esencia antigua y a los documentos auténticos. Su limite está alli donde comienzo

la hipótesiss en el plano de las reconstituciones basadas en conjeturas, todo trabajo de complemento reconocido como indlispensable por razones estéticas o técnicas aflora de la composición arquitectónica y llevará la marca de nuestro tiempo. La restauración estará siempre precedida y acompañada de un estudio arqueológico e histórico del monumento.

Artículo 10. Cuando las técnicas tradicionales se muestron inadecuadas, la consolidación de un monumento puede ser asegurado valiéndose de todas las técricas modernos de conservación y de construcción cuya eficacia haya sido demostrada con bases cientificas y garantizada por la experiencia.

Artículo 11. Las valiosas aportaciones de todas las épocas en la edificación de un monumento deben ser respetodas, puesto que la unidad de estilo no es un fin a conseguir en una obra de restauración. Cuando un edificio presenta varios estilos superpuestos, la desaparición de un estadio subyocente no se justifico mós que excepcionalmente y bojo la condición de que los elementos eliminados no tengan apenas interés, que el conjunto puesto al descubierto constituya un testimonio de alto valor histórico, arqueológico o estético, y que su estado de conservación 
se juzgue suficiente. El juicio sobre el valor de los elementos en cuestión y la decisión de las eliminaciones a efectuar no pueden depender únicamente del autor del proyecto.

Artículo 12. Los elementos destinados a reemplazar las partes inexistentes deben integrarse armoniosamente en el conjunto, distinguiéndose claramente de las originales, a fin de que la restauración no falsifique el documento artístico o histórico.

Artículo 13. Los añadidos no deben ser tolerados en tanto que no respeten todas las partes interesantes del edificio, su trazado tradicional, el equilibrio de su composición y sus relaciones con el medio ambiente.

\section{LUGARES MONUMENTALES (Conjuntos histórico-artísticos)}

Artículo $14^{\circ}$ - Los lugares monumentales deben ser objeto de atenciones especiales a fin de salvaguardar su integridad y de asegurar su saneamiento, su tratamiento y su realce. Los trabajos de conservación y de restauración que en ellos sean ejecutados deben inspirarse en los principios enunciados en los artículos precedentes.

\section{Excavaciones}

Articulo 15. Los trabajos de excavaciones deben llevarse a cabo de acuerdo con las normas científicas y con la "Recomendación que define los principios internacionales a aplicar en materia de excavaciones arqueológicas" adoptada por la UNESCO en 1956. El mantenimiento de las ruinas y las medidas necesarias para la conservación y protección permanente de los elementos arquitectónicos y de los objetos descubiertos deben estar garantizados. Además, se emplearán todos los medios que faciliten la comprensión del monumento descubierto sin desnaturalizar su significado. Cualquier trabajo de reconstrucción deberá, sin embargo, excluirse a priori; sólo la anastilosis puede ser tenida en cuenta, es decir, la recomposición de las partes existentes pero desmembradas. Los elementos de integración serán siempre reconocibles y constituirán el mínimo necesario para asegurar las condiciones de conservación del monumento y restablecer la continuidad de sus formas.

\section{Documentación y Publicación}

Artículo 16. Los trabajos de conservación, de restauración y de excavación irán siempre acompañados de la elaboración de una documentación precisa, en forma de informes analíticos y críticos, ilustrados con dibujos y fotografías. Todas las fases del trabajo de desmontaje, consolidación, recomposición e integración, así como los elementos técnicos y formales identificados a lo largo de los trabajos, será n-alli consignados. Esta documentación será depositada en los archivos de un organismo público y puesta a la disposición de los investigadores; se recomienda su publicación". 
Anexo 4: Reglamento Nacional de Edificaciones - Sección sobre obras en monumentos 
El diseño y la ubicación de las placas, rótulos y/o directorios señalados en los párrafos precedentes deberán ser autorizados por las entidades encargadas.

Las licencias municipales para la colocación de avisos comerciales en los locales ubicados en Monumentos, Ambientes Urbano Monumentales y Zonas Monumentales, deberán ser autorizadas previamente por las entidades encargadas.

No está permitida la colocación de avisos en terrenos sin construir, muros de terrenos sin construir y/o playas de estacionamiento, azoteas, fachadas laterales o posteriores, pisos superiores de los inmuebles, vías y áreas públicas en general, postes de alumbrado público y mobiliario urbano en general, puertas y ventanas de establecimientos comerciales y/o institucionales.

Artículo 16.- Las nuevas edificaciones deberán respetar los componentes de la imagen urbana que permitan su integración con los bienes culturales inmuebles existentes en el lugar, para lo cual deberán armonizar el carácter, composición volumétrica, escala y expresión formal de los citados inmuebles.

La volumetría de las construcciones debe adaptarse a la topografía de la zona y no debe alterar el medio físico (natural y artificial) del ambiente monumental.

Se deben establecer las características formales que le dan valor al ambiente monumental, tales como forma y tipo de cubiertas, alineamiento de fachadas, a fin de que las nuevas edificaciones incorporen estos elementos o armonicen con ellos y permitan una integración con las edificaciones de valor existentes en la zona.

La altura de las nuevas edificaciones deberá guardar relación con la altura dominante de las edificaciones de valor del entorno inmediato.

Los muros colindantes con terrenos sin construir o edificaciones de menor altura visibles desde la vía pública deberán tener un acabado que garantice su integración al entorno.

Los tanques de agua y cajas de ascensores no se consideran para determinar la altura de la edificación.

Estos deberán tener una altura no mayor a $3.50 \mathrm{~m}$ sobre el nivel del paramento de la fachada principal, estar retirados del plomo de la fachada y deberán estar cubiertos o tratados de manera que su presencia no altere la percepción del perfil urbano.

Articulo 17.- No está permitida la instalación de es tructuras para comunicaciones o transmisión de energía eléctrica, ni de elementos extraños (antenas de telefónica móvil, casetas, tanques de agua, etc.) que por su tamaño y diseño alterna la unidad del conjunto

Artículo 18.- Dentro del perímetro de los ambientes monumentales, no podrán ser llevadas a cabo obras de infraestructura primaria que impliquen instalaciones a nivel o elevadas visibles desde la vía pública.

Las obras de infraestructura primaria de tipo subterráneo podrán realizarse en los ambientes monumentales siempre y cuando su construcción no afecte ningún elemento de valor cultural, ni los predios colindantes.

Los elementos de infraestructura secundaria, no deberán obstruir el libre tránsito peatonal, ni la percepción de los bienes culturales inmuebles y no deben estar adosados a monumentos históricos

No están permitido el tendido aéreo de instalaciones eléctricas, de telefonía y televisión por cable.

Los medidores de los servicios de energía o gas, se deberán acondicionar en habitaciones interiores.

Las edificaciones nuevas a construirse en Zonas Monumentales se limitaran en su volumetría, dimensiones y diseño, a fin de que armonicen con los Monumentos y los Ambientes Urbanos Monumentales ubicados en dichas Zonas.

Artículo 19.- La volumetría y el diseño de las edificaciones ubicadas en Zonas Monumentales se ceñirán a las siguientes pautas:

a) Los frentes se alinearan en toda su longitud con el límite de propiedad sobre la calle.

b) En el caso que se trate de una zona donde se requiera retiro fronterizo, los frentes se mantendrán en un plano paralelo en toda su longitud al límite de propiedad sobre la calle.

c) El plano de fachada en los frentes no podrá volarse o proyectarse fuera del limite de propiedad, Las Entidades Encargadas determinaran si puede o no introducirse elementos volados individuales tales como balcones o galerías, y cual podrá ser la proyección de estos. d) La altura de edificación será la señalada para la zona por el Instituto Nacional de Cultura en coordinación con la Municipalidad Provincial correspondiente. En todo caso, la altura total de edificación deberá ser tal de permitir que se satisfagan las siguientes condiciones:

- No altera el perfil o silueta del paisaje urbano de la zona, interfiriendo con los volúmenes de las torres de las Iglesias u otras estructuras importantes de carácter monumental.

- No alterar la relación de la zona con el paisaje natural circundante en caso que este, por su topografía y caracteristicas, forme parte integrante del paisaje urbano.

- No introducir elementos fuera de escala con los Monumentos y Ambientes Urbanos Monumentales que forman parte de la zona Monumental.

\section{CAPITULO III \\ EJECUCIÓN DE OBRAS EN MONUMENTOS Y AMBIENTES URBANO MONUMENTALES}

Articulo 20.- En las Monumentos y Ambientes Urbano Monumentales, se autorizarán trabajos de conservacion, restauración, consolidación estructural, rehabilitación y mantenimiento, remodelación y ampliación.

La autorización para la ejecución de trabajos en Monumentos y Ambientes Urbano Monumentales será otorgada por el Instituto Nacional de Cultura.

Articulo 21.- En los monumentos deberán respetarse tanto la tipología como los elementos artísticos y arquitec tónicos de acuerdo a los criterios que el INC establezca.

Articulo 22.- La intervención en monumentos históricos está regida por los siguientes criterios:

a) Deberán respetar los valores que motivaron su reconocimiento como monumento integrante del Patrimonio Cultural de la Nación.

b) Solamente se permitirá la demolición parcial de un monumento previa evaluación, debiendo preponerse un proyecto de intervención total en el cual la obra nueva se integre al contexto.

c) Se podrá autorizar el uso de elementos, técnicas y materiales contemporáneos para la conservación y buen uso de los monumentos históricos.

d) Se deberán conservar las características tipológicas de ordenamiento espacial, volumétricas y morfológicas, así como las aportaciones de distintas épocas en la medida que hayan enriquecido sus valores originales.

e) Se podrán efectuar liberaciones de elementos o partes de épocas posteriores que pudieran haber alterado la unidad del monumento original o su interpretación histórica. En este caso se deberá documentar y fundamentar la intervención.

f) En casos excepcionales la reconstrucción total o parcial de un inmueble se permite cuando exista pervivencia de elementos originales, conocimiento documental suficiente de lo que se ha perdido o en los casos en que se utilicen partes originales.

g) Para demoler edificaciones que no sean monumentos históricos pero que formen parte de un ambiente monumental se deberá obtener autorización, previa aprobación del proyecto de intervención, el mismo que deberá considerar su integración al ambiente monumental. Las demoliciones solo se permiten cuando existen elementos que atenten contra la seguridad de las personas y/o la armonía urbana.

h) Los Monumentos deben mantener su volumetría y altura original, las intervenciones de adecuación y puesta en valor no deben modificar su expresión formal, características arquitectónicas, carpintería y motivos ornamentales.

i) La obra nueva que se incorpore en la zona liberada del Monumento debe guardar correspondencia con el área intangible y no exceder en altura. En caso de existir pendiente en la calle, la obra nueva no debe visualizarse desde la vereda de enfrente ni sobresalir del promedio de la volumetría de la zona o ambiente Urbano Monumental donde se ubique.

Articulo 23.- La intervención en Ambientes Urbano Monumentales está regida por los siguientes criterios:

a) Debe preservarse la unidad y carácter de conjunto, la traza urbana, su morfología y secuencia espacial. 
b) Los ambientes urbanos, plazas, plazuelas, alamedas, calles y otros deben ser conservados no solo por su carácter de áreas libres de uso publico, sino por su valor histórico.

c) No se deberán introducir diseños, materiales ni elementos urbanos atípicos. Deben conservarse especies arbóreas existentes y áreas de protección paisajística y ecológica general.

d) Los inmuebles integrantes de los Ambientes Urbano Monumentales deben mantener su volumetría y altura original, las intervenciones de adecuación y puesta en valor no deben modificar su expresión formal, características arquitectónicas, carpintería y motivos ornamentales componentes de la fachada.

e) Las edificaciones nuevas que se erijan en Ambientes Urbano Monumentales, deberán tener en cuenta, las siguientes pautas en cuanto a su volumetría, dimensiones y diseño, a fin de preservar la unidad de conjunto de dichos ambientes:

- Mantendrán el alineamiento de los frentes de las edificaciones vecinas que conforman el Ambiente Urbano.

- Los planos de fachadas no podrán volar o proyectarse fuera del límite de propiedad. Las Entidades Encargadas determinaran en cada caso si pueden o no introducirse elementos arquitectónicos volados tales como balcones, o galerías, y cual podrá ser la proyección de estos.

- Los frentes tendrán la misma altura que la altura promedio de los frentes de las edificaciones vecinas.

- Las Entidades Encargadas determinaran si puede o no introducirse volúmenes de mayor altura que la altura promedio de las edificaciones que conforman al ambiente Urbano en la parte interior de la edificación nueva.

- Los frentes a edificarse deberán armonizar, en cuanto a la forma y distribución de los vanos y otros elementos arquitectónicos, texturas y colores, con los frentes de las edificaciones existentes que conforman el Ambiente Urbano Monumental, de manera que se conserve la unidad y el carácter del conjunto.

Articulo 24.- Los inmuebles deberán ser pintados de manera integral para toda la unidad.

a) Para el pintado de los inmuebles Monumentales o de Valor Monumental necesariamente se deberá efectuar el estudio estratigráfico con el fin de determinar la capa original de pintura, pintándose el inmueble del color encontrado.

b) Cada zona Monumental deberá contar con una cartilla de colores para el pintado de los inmuebles de la Zona Monumental.

c) Los inmuebles deberán mantener unidad de color en sus fachadas, respetándose la unidad inmobiliaria. No se permite el pintado en diferentes colores, que pretenda señalar propiedades distintas. En casos en que no exista acuerdo de los propietarios, la Municipalidad determinara el color a utilizarse de acuerdo a la cartilla de colores.

d) Queda prohibido la utilización de enchapes cerámicos, tarrajeos bruñados, escarchados, materiales reflejantes, cristal espejo cuando sean atípicos a la zona monumental donde se ubica el inmueble

e) Se rehabilitaran los pisos y pavimentos de las plazas, calzadas y veredas con elementos cuyas formas y calidades sean adecuadas al transito y acordes con el carácter del ambiente.

f) El alambrado monumental de plazas y Edificios principales, se debe llevar a cabo conservando los elementos ornamentales originales, solo se permite la instalación de artefactos que garanticen un adecuado nivel de iluminación y que no produzcan distorsiones de color, ni de escala en el ambiente en que se ubiquen. Así mismo, se suprime totalmente los tendidos aéreos de las líneas de instalaciones eléctricas y telefónicas existentes.

g) En todos los espacios públicos (vías, plazas, plazuelas, pasajes), se debe considerar y rediseñar el Mobiliario Urbano, a fin de obtener el máximo aprovechamiento plástico y funcional de Área.

Artículo 25.- La intervención en el Mobiliario Urbano, debe considerar no solo la instalación de los equipos y su adecuación a la forma de los espacios y accesos viales, sino también los pisos, pavimentos y la señalización adecuada de las áreas históricas y monumentales.

Articulo 26.- Son elementos constitutivos de la traza urbana, su diseño, su estructura, su morfología y su secuencia espacial a) Queda prohibido varias el trazo de calles y plazas en las zonas monumentales, prohibiéndose el ensanche de vías y/o de prolongaciones que no se ajusten a la traza original.

b) Debe conservarse la antigua traza de la ciudad o recuperarse si esta hubiese sido alterada.

c) Los ambientes urbanos, plazas plazuelas y otros deben ser conservados, no solo por su carácter de áreas libres de uso publico, sino por su valor histórico.

Articulo 27.- Se permite la transformación de usos y funciones en los inmuebles monumentales siempre y cuando mantengan sus características tipológicas esenciales.

Los usos o destinos de los monumentos Históricos se regirán por el plan urbano establecido para la zona.

Los nuevos usos deberán garantizar el mantenimiento o mejora del nivel de calidad del inmueble y de su entorno urbano.

Es prohibido el funcionamiento exclusivo de playas de estacionamiento en inmuebles calificados como Monumento y/o integrante de Ambientes Urbano Monumentales y de valor Monumental.

Cuando se trate de inmuebles calificados como Monumento o integrantes de Ambientes Urbano Monumentales y/o de valor monumental el estacionamiento podrá resolverse fuera del lote de acuerdo a lo que dispongan las autoridades municipales.

Articulo 28.- La obra nueva en ambiente monumental deberá seguir los siguientes criterios:

a) Ser concebidas como arquitectura contemporánea, capaz de insertarse en el contexto urbano de las áreas urbanas históricas, no debiendo replicar los elementos formales del pasado.

b) La integración arquitectónica con volúmenes ya existentes implica el respeto de las proporciones de los vanos y la relación entre llenos y vacíos.

c) En las fachadas no se permite el empleo de materiales vidriados como cerámica o azulejos ni colores discordantes o llamativos cuando estos resulten atípicos a la zona monumental donde se ubique.

Articulo 29.-Las zonas arqueológicas son áreas de máxima protección por tener vestigios de la cultura material y de la vida de los hombres del pasado y merecen ser estudiados y conservados por su significación científica y cultural.

No se permite la ejecución de obras de habilitación urbana o edificación en los sitios arqueológicos.

Los sitios arqueológicos deberán estar delimitados e inscritos como tales en el Registro de Predios de los Registros Públicos.

En las zonas arqueológicas urbanas se permite la construcción de cercos perimétricos, museos de sitio, servicios higiénicos, guardianía, iluminación artificial y elementos de protección para los visitantes y servicios complementarios acordes con el plan de manejo del Sitio.

Las edificaciones colindantes con los límites del sitio arqueológico deberán mantener una altura acorde con la altura del monumento arqueológico y tener características que no alteren la visual del sitio.

Articulo 30.- Los proyectos de intervención en bienes culturales inmuebles, para ser sometidos a su aprobación deberán contener la siguiente información:

\section{a) Estudio Histórico:}

- Planos anteriores

- Fotografías o grabados anteriores del inmueble

- Documentos de propiedad.

\section{b) Levantamiento del estado actual}

- Plano de las fachadas del perfil urbano de ambos frentes de la calle donde se ubica el inmueble.

- Fotografías del exterior y del interior del inmueble - Planos de plantas, cortes y elevaciones. Indicación de materiales de pisos, techos y muros, reseñando su estado de conservación. Indicación de intervenciones efectuadas al inmueble.

- Planos de instalaciones eléctricas y sanitarias, indicando el estado de conservación.

- Memoria descriptiva de las funciones actuales y de los componentes formales 
c) Propuesta de conservación-restauración:

- Plano de ubicación. Planos de plantas, cortes y elevaciones indicando las intervenciones a efectuar, las soluciones estructurales a adoptar, y los acabados que se proponen

- Plano de techos. Detalles constructivos y ornamentales de los elementos a intervenir, consignando las especificaciones técnicas necesarias (materiales, acabados dimensiones)

- Planos de perfil urbano incluyendo la propuesta (escala $1 / 200$ )

- Planos de instalaciones sanitarias y eléctricas

- Memoria descriptiva en la que se justifiquen los criterios adoptados en las intervenciones planteadas, el uso propuesto y las relaciones funcionales, así como las especificaciones técnicas necesarias.

Articulo 31.- Los proyectos de edificaciones nuevas n zonas monumentales, deberán tener, además de los requisitos establecidos en la Norma GE 020 del presente Reglamento, lo siguiente:

a) Fotografías de los inmuebles colindantes;

b) Fotografías de la calle donde se va a edificar; $y$

c) Plano del perfil urbano de ambos frentes de la calle donde se ubica el predio, incluyendo la propuesta.

Articulo 32.- Los propietarios, inquilinos u ocupantes de los Monumentos y de los inmuebles en Ambiente Urbano Monumental o Zona Monumental, sean personas naturales o jurídicas, publicas o privadas, son sus custodios y están en la obligación de velar por la integridad y conservación de su estructura, motivos arquitectónicos, ornamentación y demás elementos que forman parte del monumento.

Articulo 33.- No se permitirá dentro de las zonas monumentales la subdivisión ni la independización de la unidad inmobiliaria cuando su concepción original haya sido unitaria. En los casos en que la unidad inmobiliaria haya sido concebida en varias partes orgánicas y autosuficientes, estas pueden ser independizadas pero el inmueble no puede ser subdividido debiendo conservar sus características prediales originales.

En ningún caso los inmuebles declarados Monumentos deben ser subdivididos.

La independización de una unidad inmobiliaria considerada de valor monumental, solo puede realizarse, cuando la parte a independizarse no contenga valores monumentales, no sea necesaria para el servicio o puesta en valor del monumento, no establezca servidumbres, no cause daño o detrimento alguno a los valores culturales del inmueble y no forma parte de si concepción unitaria original.

En los casos de que las unidades inmobiliarias hayan sido objeto de subdivisiones del predio original, se promoverá su acumulación y la conformación de organizaciones asociativas con personería jurídica, que representen a los propietarios a través de condominios de propiedad.

En los monumentos declarados, la acumulación procederá cuando las unidades inmobiliarias originales hayan sido objeto de subdivisiones y en el caso de que el predio por acumular sea necesario para el servicio y puesta en valor monumental existente.

Articulo 34.- El uso que se de a los monumentos deberá ser decoroso y compatible con el respeto que merecen las obras por su categoría de Monumentos, asegurándose la conservación en toda sus partes, estructura, forme, motivos ornamentales y demás elementos tales como mobiliario y otros que forman parte integrante de su arquitectura.

Sea cual fuere el uso que se le de a un Monumento, no se permitirán transformaciones que vayan en menoscabo de su arquitectura y que adulteren su fisonomía original para los fines de su utilización.

Las Municipalidades no otorgarán licencia de apertura de establecimientos de ningún tipo a aquellos considerados monumentales sin la autorización del Instituto Nacional de Cultura.

Articulo 35.- Cuando el Instituto Nacional de Cultura no realice las obras directamente, es su función la supervisión de la ejecución de las mismas.

En el caso de estas obras de restauración y en aquellas de refracción, modificación y/o ampliación, la supervisión garantizara el estricto cumplimiento de lo contenido en los planos, especificaciones y demás documentos que forman parte de los proyectos de restauración, modificación y/o ampliación aprobados por el Instituto Nacional de Cultura.

Articulo 36.- Los profesionales, contratistas u otros, ejecutores de las obras están obligados a cumplir lo que disponga el Instituto Nacional de Cultura, respecto a dichas obras.

Articulo 37.- Cuando sea imprescindible realizar trabajos de emergencia a fin de evitar perdida o deterioro de un monumento, la persona o entidad propietaria del Monumento o responsable del mismo, dará cuenta inmediata del Instituto Nacional de Cultura, quien dictara las medidas preventivas correspondientes. Asimismo deberá comunicar de tales hechos a la Municipalidad Provincial o Distrital correspondiente.

Articulo 38.- En casos de desastres, el Instituto $\mathrm{Na}$ cional de Cultura, a fin de proteger, conservar y recupera la identidad propia de los Centros Históricos, Monumentos, Zonas y Ambientes Urbano Monumentales afectados, dictara los lineamientos y orientaciones técnicas que deben ser observados para su restauración, recuperación y/ o reconstrucción.

\section{III.2. ESTRUCTURAS}

\section{NORMA E.010 \\ MADERA \\ CAPITULO 1 \\ AGRUPAMIENTO DE MADERAS PARA USO ESTRUCTURAL}

\section{ARTICULO 1: NORMAS A CONSULTAR}

ITINTEC 251.001 MADERAS. Terminología.

ITINTEC 251.011 MADERAS. Método de determinación de la densidad.

ITINTEC 251.104 MADERA ASERRADA Madera Aserrada para Uso Estructural. Clasificación Visual y Requisitos.

ITINTEC 251.107 MADERA ASERRADA. Madera Aserrada para Uso Estructural. Método de Ensayo de Flexión para Vigas a Escala Natural.

\section{ARTICULO 2: OBJETIVOS}

Este capítulo establece el agrupamiento de las maderas para uso estructural, en tres clases denominadas $A$, $B$ y $C$ y fija los requisitos y procedimientos que se deberá seguir para la incorporación de especies a los grupos establecidos.

\section{ARTICULO 3: CAMPO DE APLICACIÓN}

1.1. Los valores establecidos en este capítulo son aplicables a madera aserrada que cumple con los requisitos establecidos en la norma ITINTEC 251.104. Maderas coníferas de procedencia extranjera podrán agruparse siempre que cumplan con normas de calidad internacionalmente reconocidas y que resulten en características de resistencia mecánica similares a las de los grupos establecidos en esta Norma.

1.2. Los valores establecidos en este capítulo son aplicables a madera aserrada en condiciones normales. Para condiciones especiales los requisitos serán establecidos en las normas correspondientes.

ARTICULO 4: DEFINICIONES

Para los fines de este capítulo se define:

4.1. Densidad Básica.- Es la relación entre la masa anhidra de una pieza de madera y su volumen verde. Se expresa en $\mathrm{g} / \mathrm{cm}^{3}$.

4.2. Esfuerzo Básico.- Es el esfuerzo mínimo obtenido de ensayos de propiedades mecánicas que sirve de base para la determinación del esfuerzo admisible. Este mínimo corresponde a un límite de exclusión del $5 \%$ (cinco por ciento). 
Anexo 5: El Arte de Proyectar Neufert sección sobre museos 


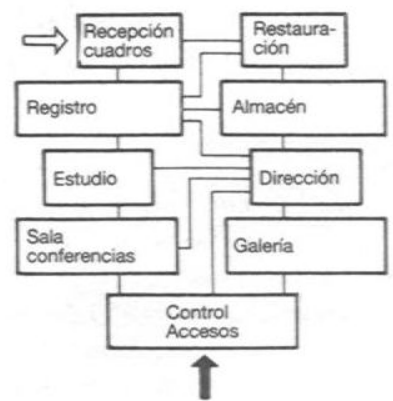

Esquema de circulaciones

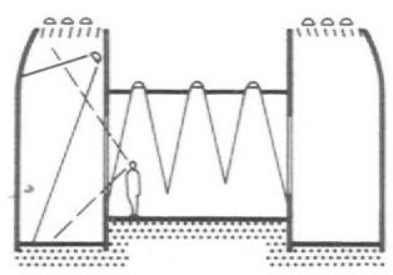

(3) Sección tipica de un museo de historia natural

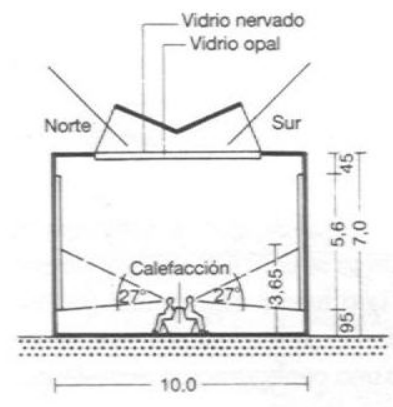

Sala de exposiciones bien iluminada, según los estudios de Boston

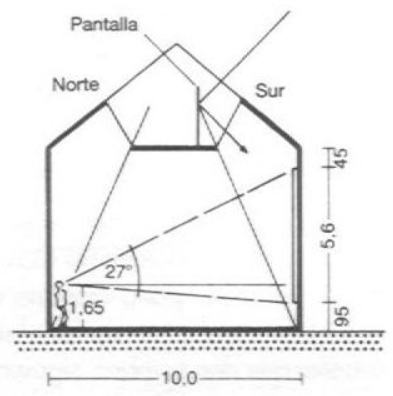
(6) Sala con iluminación óptima de dos
lados, según $S$. Hurst Seager $\rightarrow \mathbb{M}$

Guia corredera
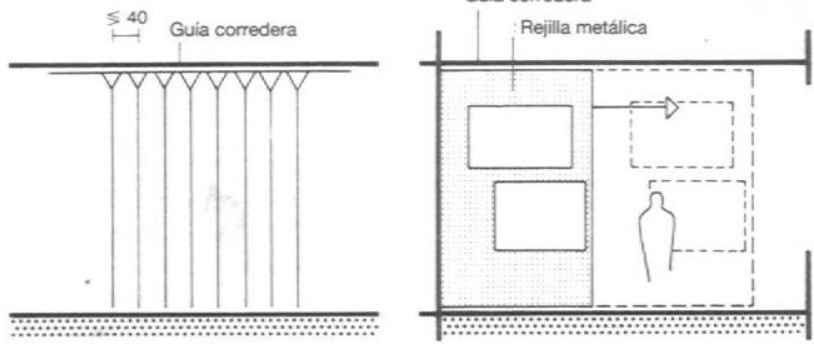

Almacén de cuadros con bastidores móviles de rejilla metálica, en la que se pueden fijar libremente los cuadros y extraerlos de forma fácil

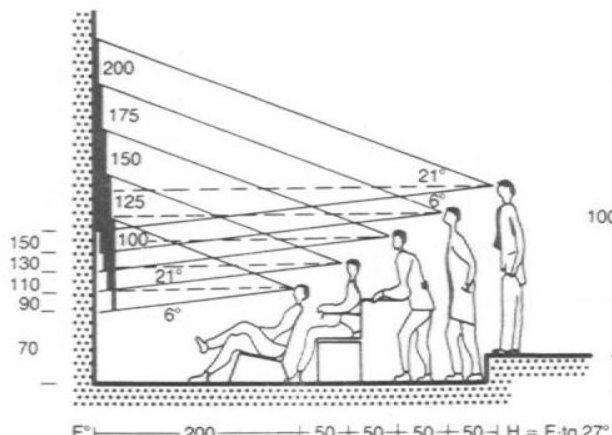

$E^{\circ} \longmapsto 200-50+50+50+50+r$

(9) Campo visual - altura, tamaño y separación
MUSEOS

Salas: las salas destinadas a exponer obras artísticas y científicas han de servir para:

1. protegerlas de la humedad, de la sequedad, del sol, del polvo, de agresiones o robos y

2. mostrarlas bien iluminadas (en el sentido más amplio), lo cual se consigue mediante una clasificación de las obras:

a) en obras destinadas a ser estudiadas (grabados, dibujos originales, etc.) que se conservan en carpetas guardadas en armarios (con cajones) de unos $80 \mathrm{~cm}$ de profundidad y $160 \mathrm{~cm}$ de altura; b) en obras exhibidas al público (óleos, frescos, exposiciones itinerantes, etc.).

El público ha de poder contemplar las obras expuestas sin esfuerzo. Esto exige fijar unos itinerarios de recorrido y ordenar las obras a exponer.

A ser posible se han de situar cada grupo de cuadros en una única sala y cada cuadro en una pared. Esto exige salas pequeñas. La proporción entre superficie de pared y superficie en planta es mayor en las salas grandes necesarias para colgar grandes cuadros, ya que el tamaño de las salas depende del tamaño de los cuadros. El ángulo visual del hombre son $54^{\circ}$, o $27^{\circ}$ hacia arriba desde el ojo del espectador, lo cual implica que dada una distancia de contemplación de $10 \mathrm{~m}$, los cuadros se han de colgar desde $4,90 \mathrm{~m}$ por encima del punto de vista $\rightarrow$ (6) hasta $70 \mathrm{~cm}$ por debajo. Sólo los grandes cuadros superarán estos límites por arriba y por abajo. Los cuadros de tamaño pequeño deberían colgarse de manera que su centro de atención (línea de horizonte del cuadro) quedase a la altura de los ojos $\rightarrow$ (9) Superficie necesaria por cuadro .................. $3-5 \mathrm{~m}^{2}$ de pared Superficie necesaria por obra pictórica .......... $6-10 \mathrm{~m}^{2}$ en planta Superficie necesaria por cada 400 monedas ....... $1 \mathrm{~m}^{2}$ de vitrina El cálculo de la iluminación adecuada en un museo $\rightarrow \square$ es muy teórica, lo decisivo es la calidad de la luz, por ello, los ensayos americanos tienen mayor interés $\rightarrow \mathbb{Q}$. Últimamente se tiende a la iluminación artificial, en vez de intentar aprovechar la luz natural siempre cambiante aunque entre a través de lucernarios orientados a norte. En una sala con iluminación natural lateral, la superficie óptima para colgar cuadros se sitúa entre los $30^{\circ}$ y los $60^{\circ}$ de reflexión de la luz, para una altura del techo de $6,70 \mathrm{~m}$ y el antepecho de ventana de $2,13 \mathrm{~m}$ en el caso de pinturas, o de 3,04 a $3,65 \mathrm{~m}$ en el de esculturas, según los estudios de Boston $\rightarrow$ (10).

Ordenación del conjunto: es preferible disponer varias alas alrededor de la entrada que un pasillo interminable que dé la vuelta a todo el edificio. Se ha de prever suficiente espacio para desempeñar los trabajos de embalaje, envio, administración, salas para proyectar diapositivas, talleres de restauración y salas de conferencias $\rightarrow$ Escuelas. Los castillos, palacios y monasterios deshabitados son idóneos para su transformación en museos, suelen ofrecer un marco más adecuado para exponer los objetos históricos que los llamados fríos edificios modernos.
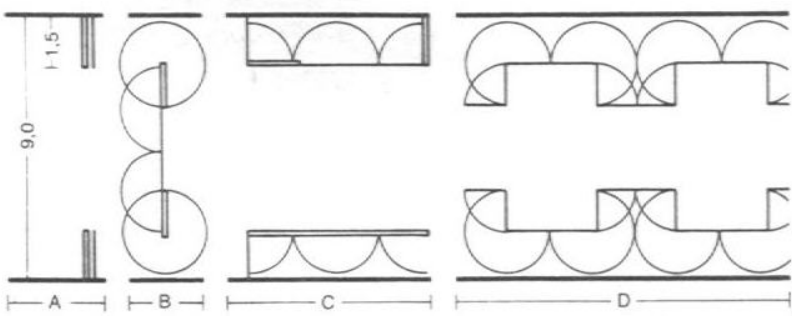

(8) Sala de exposiciones con mamparas

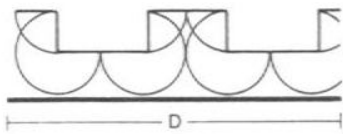

tiples posibilidades de ordenar la sala
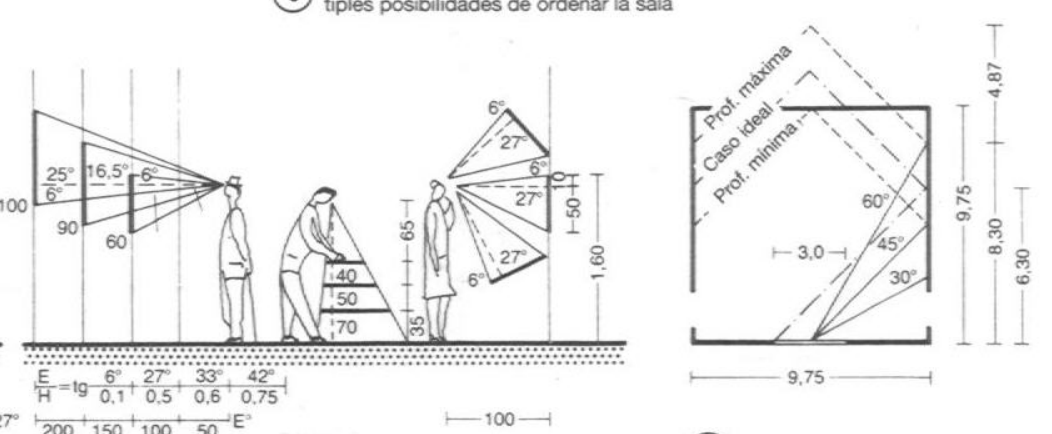

(10) Sala de exposiciones con luz lateral 


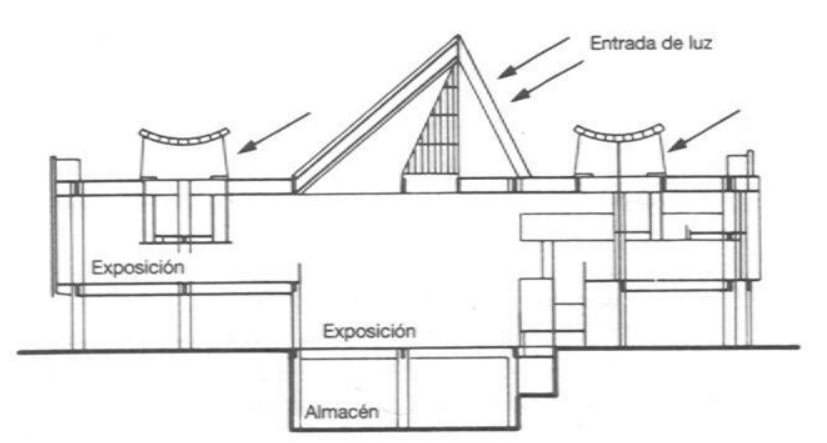

(1) Museo Nacional de Arte Occidental, Tokio. Sección

Arq.: Le Corbusie

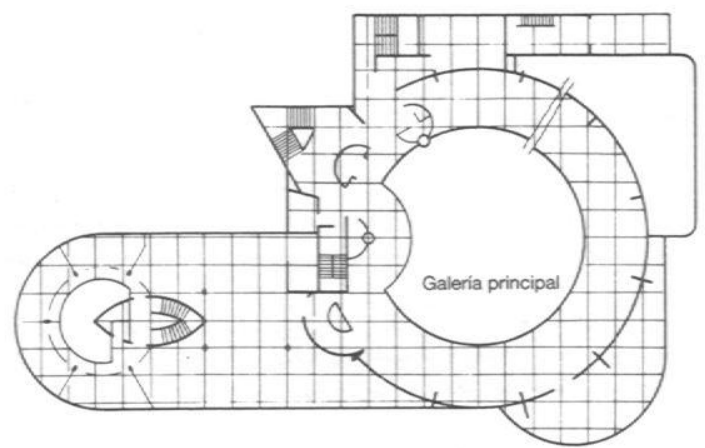

(2) Museo Guggenheim, Nueva York. Planta $\rightarrow$ (3) + (4) + (5)

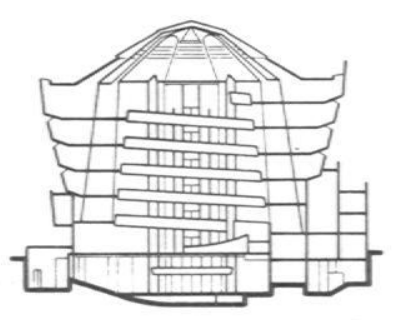

(3) Sección $\rightarrow$ (2)

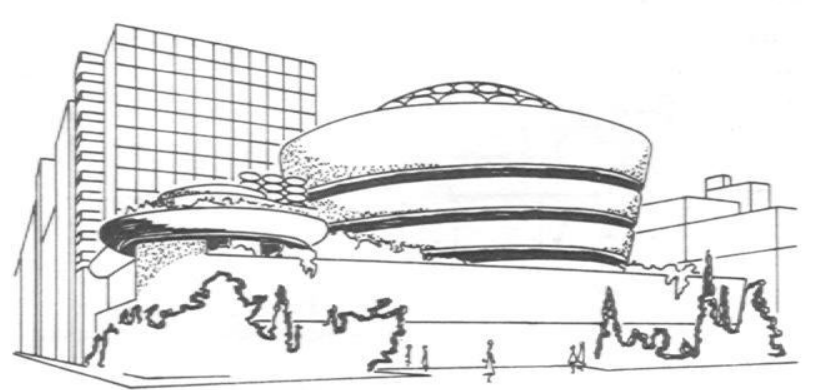

(5) Vista exterior (2) - (4)

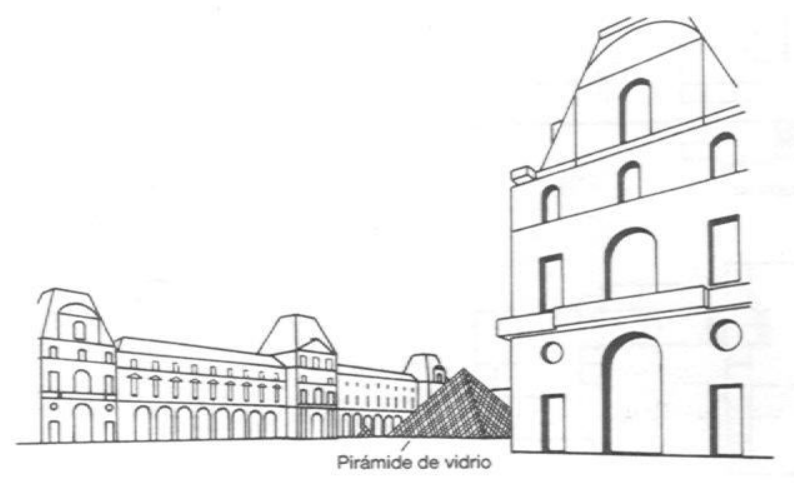

(6) Grand Louvre, Paris

Arq.: Pei y asociados

\section{MUSEOS \\ EJEMPLOS INTERNACIONALES \\ $\rightarrow \square$}

Los museos no deberían proyectarse exclusivamente como lugar para realizar exposiciones, sino también como centro cultural. Esta multifuncionalidad debe reflejarse en el programa de espacios. Salas de exposiciones permanentes e itinerantes.

Trabajo, estudio: bibliotecas, mediotecas, salas de conferencias. Relajación: zonas de descanso, cafetería, restaurante.

Almacenaje, conservación, depósitos, talleres, organización y administración.

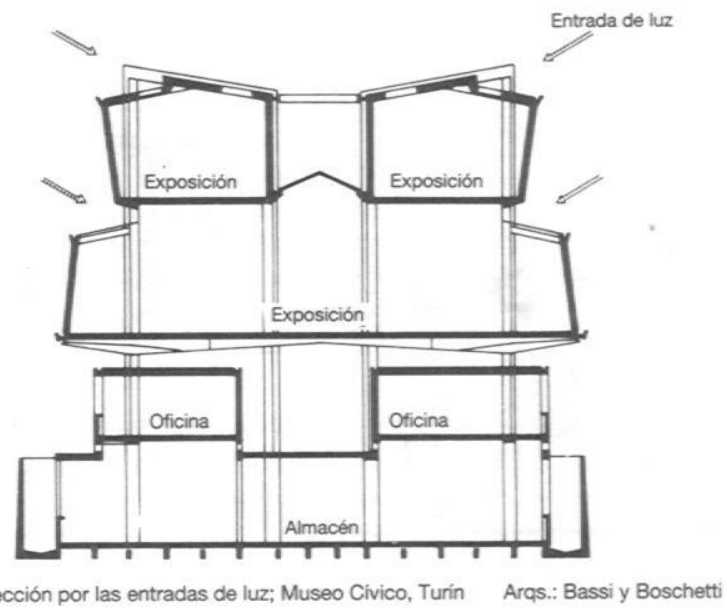

(7) Sección por las entradas de luz; Museo Civico, Turín Arqs.: Bassi y Boschetti

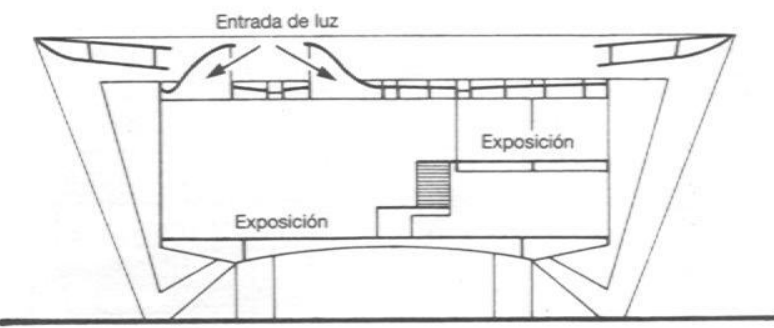

(8) Museo de Arte Moderno, Rio de Janeiro.

Arq.: Reidy Sección y entrada de luz

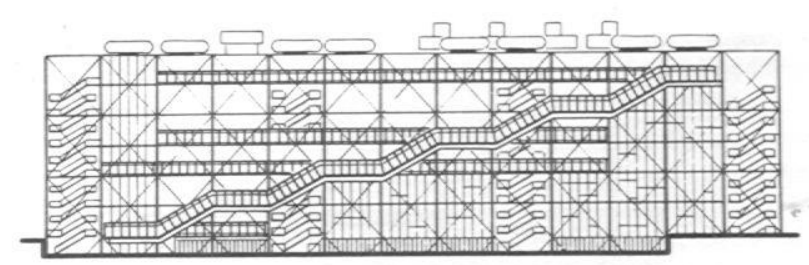
(9) Centro Pompidou, París.

Arqs.: R. Rogers y R. Piano
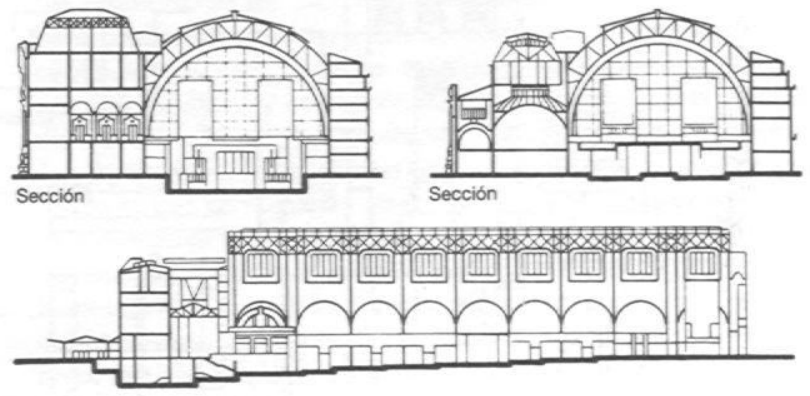

(10) Museo Gare D'Orsay, París

Arq.: G. Aulenti Rota 


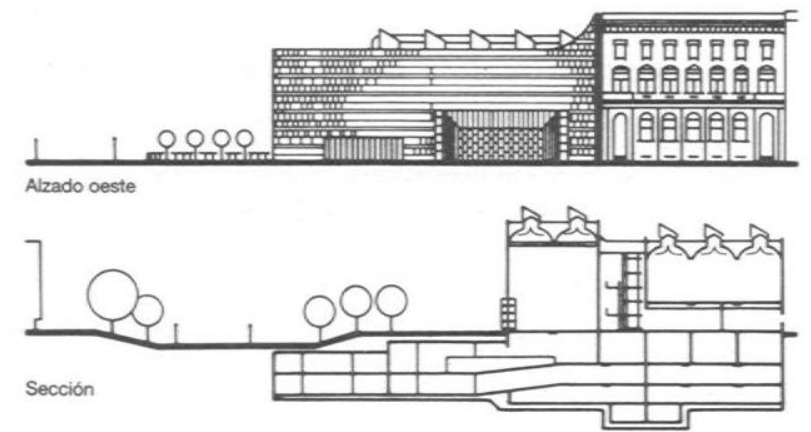

(1) Colección de Arte de Renania del Norte, Düsseldorf

Arqs.: Dissing y Wertling, Copenhague

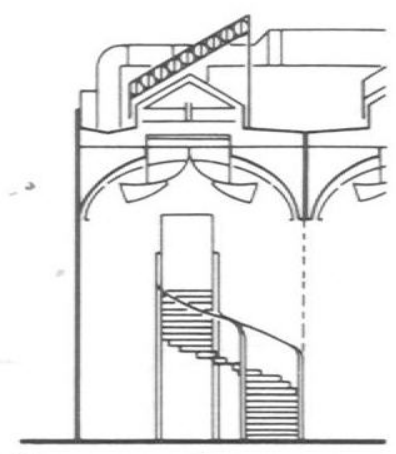

(2) Detalle de la iluminación

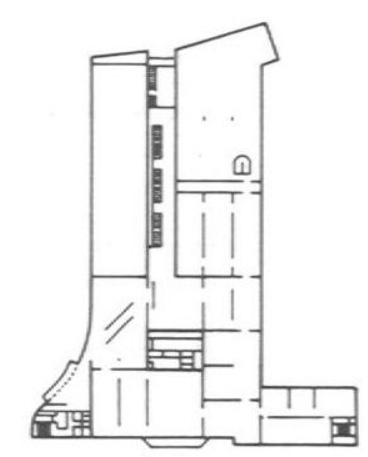

(3) Planta

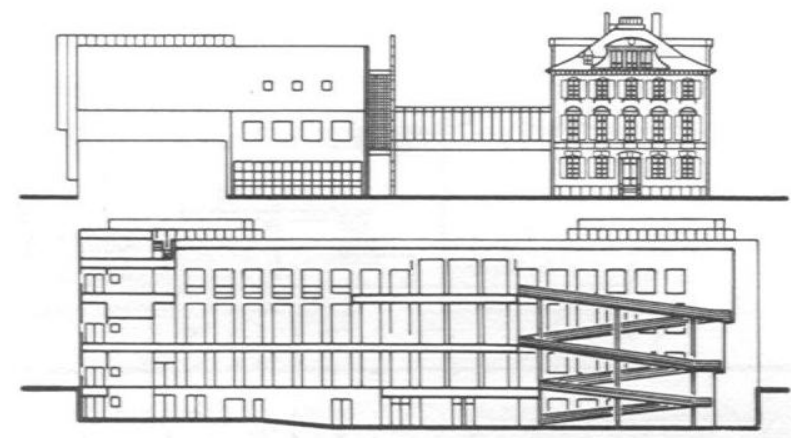

(6) Museo de Artes Aplicadas, Frankfurt.

Arq.: Richard Meier
MUSEOS

EJEMPLOS ALEMANES

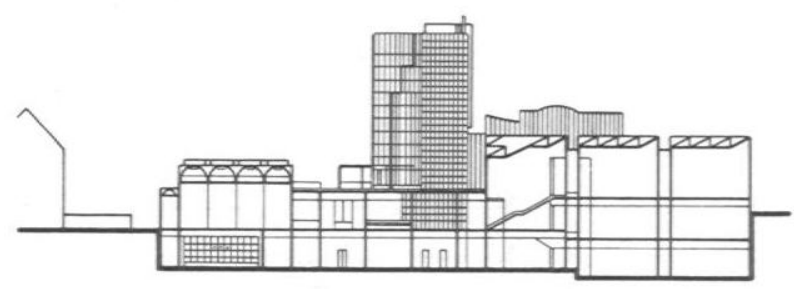

(4) Museo de Arte Moderno, Mönchengladbach

Arqs.: H. Hollein y Schmitt

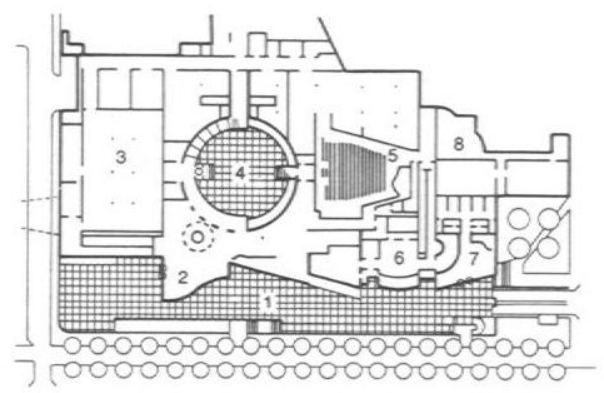

Leyenda: $\rightarrow$ (5)

1 Terraza de entrada

2 Vestibulo

Patio de esculturas

Sala de conferencias

7 Vestibulo música

de cámara

Escuela superior
de música

(5) Ampliación de la Staatsgalerie, Stuttgart $\quad$ Arqs.: Stirling, Wilfried
(5)

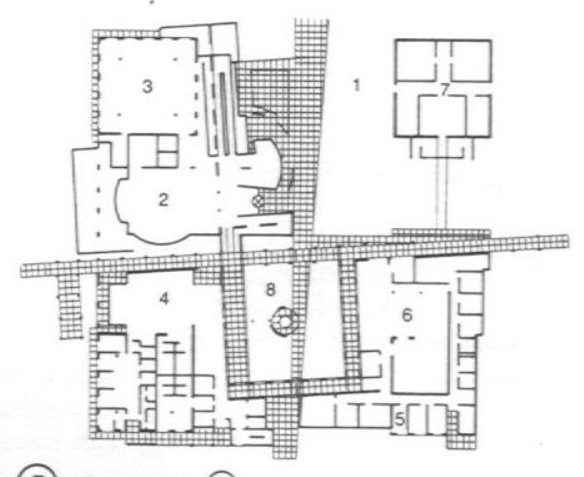

Leyenda: $\rightarrow$ (7)

1 Patio de entrada

3 Exposición itinerante

5 Restaurante

Villa Meteca

Patio ajardinado

(7) Planta baja $\rightarrow$ (6)
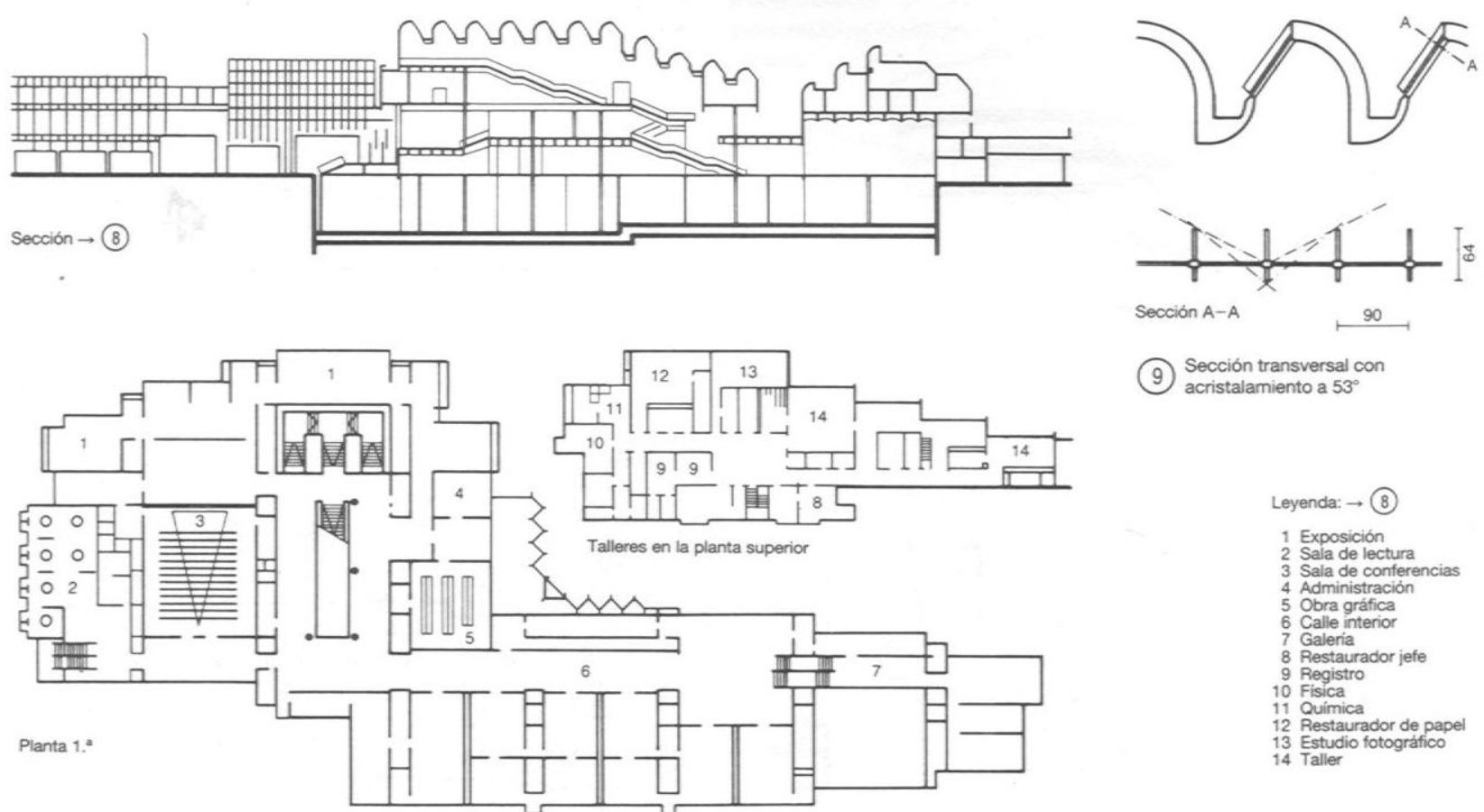

(9) Sección transversal con

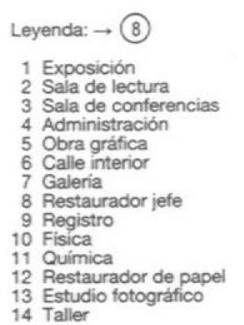

(8) Museo Wallraf-Richards, Museo Ludwig, Colonia

Arqs.: Busmann y Haberer 
Anexo 6: Plazola V.8 - Capítulo de Museos - Sección sobre áreas y programa 
Locales. Están integrados por diversas colecciones o testimonios culturales del lugar (Museo Histórico Fuerte de san Diego, Muralla china, etc.).

Nacionales. Pretenden dar una visión general de la formación histórica del pais, desde sus orígenes hasta el presente.

Regionales. Muestran el desarrollo histórico de cada estado o región del pais.

En la acutalidad el museo tiene que ser fundamentalmente un centro de comunicación entre el objeto y el espectador que propicie al hombre a vivir emocional y psicológicamente la confrontación con el objeto y su significado.

\section{PLANIFICACION}

Dentro de cualquier museo debe existir una organización estratégica para el desarrollo de las exposiciones, las cuales son de tres tipos:

Exposición permanente. Representa el tesoro del museo.

- Exposición temporal. Es la que permanece durante un lapso de dos o más meses en un museo.

Exposición de novedades. Es el anexo donde se exhiben las nuevas adquisiciones del museo.

\section{PERSONAS QUE INTERVIENEN} EN EL DISEÑO DEL MUSEO

El museo por ser un lugar público o privado de enseñanza, requiere un diálogo entre una cultura y el hombre; su creación está precedida por la investigación y por la definición del objeto finalidad del mismo, de la que se desprende la labor museoló gica de conservación, protección y uso del recinto. Los museos se crean mediante dos lineas paralelas: la línea del equipo de asesores científicos y conservadores dedicados a la colección, y la línea de los arquitectos y museógrafos que deben darle forma, secuencia y contemporaneidad a los espacios, ritmos, dimensiones, etcétera, para que la finalidad pedagógico-estética tenga proyección humana íntegra.

Los museos son el resultado de una ardua labor de especialistas: arquitectos, museógrafos, investigadores, restauradores, asesores educativos $e$ incluso personal de seguridad.

Debe haber interdependencia entre asesores, cientificos, arquitectos, investigadores, estudiantes y artistas, lo cual es determinante para darle fisonomía propia al partido y a los espacios, y conseguir una ubicación cronotópica correcta de la obra, que es el principal problema arquitectónico, porque engloba a todos los demás.

La esencia del proyecto debe ser experiencia viva que exige que al transitar o habitar sus espacios se produzca una comprensión del presente gracias a la visión retrospectiva, y no sólo una observación del pasado.
La arquitectura debe ser auténtica y verdadera y contener la formación espacial del programa planteado por todos los que intervienen en la obra que se construye.

Todos ellos deben realizar diferentes acciones que permitan cumplir con exito las funciones fundamentales de todo museo: la conservación y preservación del patrimonio y su promoción y difusión de éste entre la sociedad.

Para elaborar él programa arquitectónico, la relación entre los arquitectos y el resto de los profesionistas debe ser muy estrecha, a fin de tomar en cuenta todas las necesidades de tal manera que se logre un equilibrio entre su ubicación, funcionamiento y circulación.

El programa tendrá como fin ser dinámico y social, generador de múltiples actividades, eventos y servicios al visitante en su difusión cultural.

\section{UBICACION Y TERRENO}

Para la edificación de un museo hay restricciones en cuanto a la ubicación. Los reglamentos establecen como condición contar con estacionamiento y que los accesos sean amplios y no obstruyan la circulación vial.

Si el museo será educativo, se ubicará en lugares estratégicos entre la extensa red de escuelas públicas y particulares de fácil acceso.

En el caso de museos de sitio se debe llevar a cabo un levantamiento topográfico, estudios orográfico, hidrológico, climático, de vegetación, vientos dominantes, materiales y acerca de la historia del lugar; en los museos urbanos se realiza un análisis detallado del área circundante al terreno, traza urbana, fondo legal, casco urbano, equipamiento (hoteles, estacionamiento, comercios), infraestructura, vialidad, dirección de circulación, ancho de las vías principales, etc.

En el caso de una adaptación la ubicación del predio se realiza considerando el edificio que reúna las mejores condiciones en adaptación a museo por su espacio y su localización. Se debe realizar un levantamiento del sitio considerando un radio de acción de por lo menos $300 \mathrm{~m}$ para analizar tipos de construcciones, si hay edificios catalogados como históricos o considerados patrimonio de la humanidad que se encuentren alrededor del edificio o dentro de ese radio para determinar la factibilidad constructiva: planos de equipamiento, infraestructura (agua, luz, drenaje, teléfono, otros), transporte, alturas de construcciones, estilo y construcción dominante.

En un museo de planta nueva. La elección del sitio se hace en coordinación con los especialistas que intervienen en el proyecto arquitectónico, asesores de contenido y constructores.

Primero se define el objeto y función del museo que está determinado principalmente por la colección que se expondrá. Por lo general, con base en este dato se determina el estilo arquitectónico de la construcción. 


\section{PROYECTO URBANISTICO}

Al iniciar el proyecto se debe realizar un estudio para lograr una buena planificación. Por la magnitud del proyecto, es necesario contextualizar el inmueble en el entorno urbano y regional considerando los siguientes elementos:

Las referencias inmediatas del inmueble, como calles, plazas, edificios públicos, vecinos y colindancias. Se procede a delimitar el terreno para crear un plan de aprovechamiento que comprende uso de suelo con sus accesos principales y su acceso exterior, uso de lotes colindantes y límites de terreno.

Se analizan las condiciones de propiedad inmobiliaria, como adquisición de terreno, costo de la adquisición y tiempo de trámites. Se debe considerar la posibilidad de construcción por etapas, además de obtener información sobre la infraestructuar, como agua, luz y drenaje.

Se recomienda emplear en el diseño general, el diseño de acabados y la museografía, elementos formales y materiales de la región con el objeto de que le den personalidad propia al inmueble.

El entorno natural es un auxiliar inmediato de cualquier propuesta arquitectónica, ya que muestra colores, formas y texturas que pueden ser retomadas para definir su carácter presente y futuro.

\section{PLAN ECONOMICO}

La economía es parte fundamental para la operación de los museos públicos o privados. Estos se apoyan en los recursos generados por sus propios visitantes y también en las aportaciones del Estado o por Asociaciones de Amigos de los Museos o convenios con algunas empresas o sociedades.

En la actualidad, los grandes centros culturales son generadores de una economia en potencia por contar dentro de su diseño con espacios destinados al comercio y promoción de los objetos que en él se exhiben, cafeterías, restaurantes y bares.

\section{ADAPTACIONES Y AMPLIACIONES}

El proyecto de crecimiento en un museo se puede establecer con base en las colecciones que contenga y las mejoras que requiera para el servicio al público, en varias formas:

Ampliación. Construcción de uno o varios anexos según planes de renovación.

Adaptación. Obra que se hace en un museo o una construcción ya existente, adecuando los espacios a las necesidades y procurando respetar los valores arquitectónicos del inmueble.

Crecimiento aumentando techo. Esta es una de las formas de ampliación más sencilla, ya que sólo se anexa una estructura al techo.

Crecimiento entre pisos. Cuando se trata de construcciones antiguas se aprovecha su altura para ganar entrepisos.
Crecimiento por sustitución sin aumentar volumen. Si el edificio es antiguo, por tener otra distribución, debe sufrir cambios y adaptaciones en sus partes interiores sin que se afecte su estructura.

Construcciones subterráneas. Son las que se encuentran abajo del edificio o forman un sótano.

Aumentos parciales al edificio. Esto se logra por medio de pórticos, terrazas, techado de patios, etc.

Crecimiento aumentando volumen. Las propuestas son variables, desde demoliciones parciales del edificio y construcción de áreas nuevas o anexando terrenos vecinos o restaurando espacios.

Construcción nueva. Es la más común para el nuevo concepto de los grandes centros culturales de la actualidad.

\section{ORGANIZACION}

El museo es parte de una de las propuestas culturales más buscadas y promovidas por las instituciones gubernamentales, la iniciativa privada y la sociedad civil.

Esto se debe al gran número de visitantes que liegan a estos espacios, lo que permite una amplia difusión de ideas y conocimientos de sus colecciones. Por esta razón, el museo debe generar toda una gama de actividades y servicios para atender a un público diverso.

Para hacer frente a todos estos aspectos, el museo requiere una organización interna eficaz, capaz de realizar labores de planeación, administración y ejecución de programas de trabajo. Los espacios destinados para estos servicios requieren un porcentaje considerable de la superficie del inmueble (40\% o más).

Su edificación debe generar una imagen propia, identificable como museo y capaz de integrarse al entorno, lo cual significa tomar en cuenta las relaciones entre las escalas urbana, arquitectónica, social, cultural y ecológica para establecer un adecuado planteamiento arquitectónico.

\section{INFORMACION}

La información al público sirve para dar la bienvenida al visitante del museo, quién se apoyará en este servicio para que su visita sea una experiencia completa; esta puede ser proporcionada con:

Medios orales. Realizados por los guías especializados en el tema que se presenta en la exposición; con un sentido práctico y breve dan una explicación verbal dentro de la sala.

Medios impresos. Son folletos por medio de los cuales se informa al público en detalle acerca de lo que se exhibe, la distribución del museo y todo lo que éste contiene.

Medios técnicos. Es todo el material formado por audífonos, audiovisuales, computadoras digitales, multimedia, realidad ritual, etcétera. 


\section{SALAS DE EXPOSICION}

El diseño de las áreas de exposición debe ser adaptable a propuestas museográficas diversas. Se debe considerar la inclusión de piezas de gran tamaño (estelas) o piezas medianas y de pequeñas dimensiones (escultura y cerámica). Asi mismo, debe haber espacios para maquetas, dioramas o murales.

Para la exhibición de cualquier exposición, los museos cuentan con tres tipos de salas:

Salas de exposición permanente. Ameritan un estudio detallado en donde se analice el volumen y carácter de la exposición para determinar la superficie por ocupar y las dimensiones del espacio. En este análisis se considera el formato de la exposición de las piezas, la representación vertical, horizontal o en varios niveles que no debe romper la temática y debe establecer el recorrido para definir la circulación.

Sala de exposición temporal. Es el lugar donde las piezas se renuevan constantemente por lo que el manejo del espacio debe ser flexible y apto para el montaje, con fácil acceso, recorrido novedoso y separado de la sala de exposición permanente. El acondicionamiento debe ser adecuado a la colección y la ubicación e independiente de la sala de exposiciones permanentes.

Por medidas de seguridad asi como por la propia comodidad de los visitantes, las áreas de exhibición y de servicios deben estar separadas de las zonas internas y de las oficinas del museo y, de preferencia, con un solo acceso general desde el exterior, salvo en el caso del auditorio.

Salas de exposición de novedades. Sus espacios se deben diseñar con cierta flexibilidad para albergar todo tipo de objetos y espectáculos relacionados con el arte y el mundo de las novedades. Aquí resalta la museografía; las fuentes de información son breves y claras.

\section{MUSEOLOGIA}

La importancia del museo en la vida contemporánea, ha llevado al surgimiento de una ciencia: la museologia que trata acerca de la organización e instalación de los museos.

La museología o ciencia del museo estudia la historia de los museos, su función en la sociedad, los sistemas especificos de investigación, conservación, educación y organización, así como las relaciones entre el entorno físico y la tipología.

Existen tres componentes en la museología actual: la escala intima del contacto personal y privado con los objetos (contenido) de colección del museo; la experiencia espacial interna (continente); y, finalmente, la imagen pública del edificio y su situación como tal, un elemento dominante, ya que es la generadora de una composición urbana particular.

Uno de los principales puntos de toda institución museística lo constituyen las perfectas condiciones de exhibición al público de sus obras.
Cuando se organiza una sala de exposiciones deben valorarse distintos factores ambientales que pueden deteriorar las obras (contaminación, humedad, excesiva luminosidad, temperatura), asi como la posible curiosidad del público que ha obligado a la instalación de vitrinas y cordones de separación que marcan una separación entre el observador y el objeto y evitan cualquier daño o sustracción. El enorme valor de lo expuesto ha llevado a establecer avanzados sistemas de seguridad. Todas estas medidas de protección no deben impedir en ningún momento, por otra parte, la perfecta visibilidad del material museístico.

El creciente interés de los museos por integrarse a la sociedad y explotar sus posibilidades educativas impulsó la creación de un lenguaje propio, en el que los objetos ya no aparecieran aislados, sino acompañados de distintos documentos e innovadores progresos técnicos (fotografías, paneles, audiovisuales, etcétera).

Ello debe ir unido, por supuesto, a una organización racional del espacio, luminosidad suficiente y una serie de señalizaciones y textos explicativos, que sirvan de orientación al público.

Las más innovadoras tendencias museológicas tienden a convertir al espectador en un ente activo que puede ver, hacer y tocar.

Este nuevo concepto representa estrategias de planificación basadas en un conocimiento analítico y físico de las condiciones sociales del ambiente, así como un inventario sistemático de los materiales existentes y una clara evaluación de los medios disponibles tanto en lo que se refiere a los recursos humanos como logísticos.

\section{MUSEOGRAFIA}

La museografía es una actividad artistica, cuyo dominio supone un poder creador, aparte de cultura e inventiva visuales y de conocimientos históricos y teóricos-artísticos.

En ella se considera que el museo debe ser una unidad viva y un instrumento para la popularización de la cultura, que el museo debe salir al encuentro del público, convirtiéndose en centro dinámico de la vida de la comunidad.

La museografía significa clasificar obras, adquirirlas, conservarlas y exhibirlas; su misión principal es formar parte activa de la cultura de un pais determinado.

Es un arte que se desarrolla con el fin de exaltar los valores artisticos y educar la sensibilidad y la imaginación del espectador para que esté en condiciones de disfrutar y recrear el arte. Así, la museografía convierte el legado artístico en participación popular.

La museografía, por medio de los recursos estéticos, debe crear plataformas valorativas para confrontar al espectador con la obra de arte y posibilitar la vivencia artística, plenamente. Es condicionante 
ORGANIGRAMA DE SERVICIO DE MUSEOGRAFIA

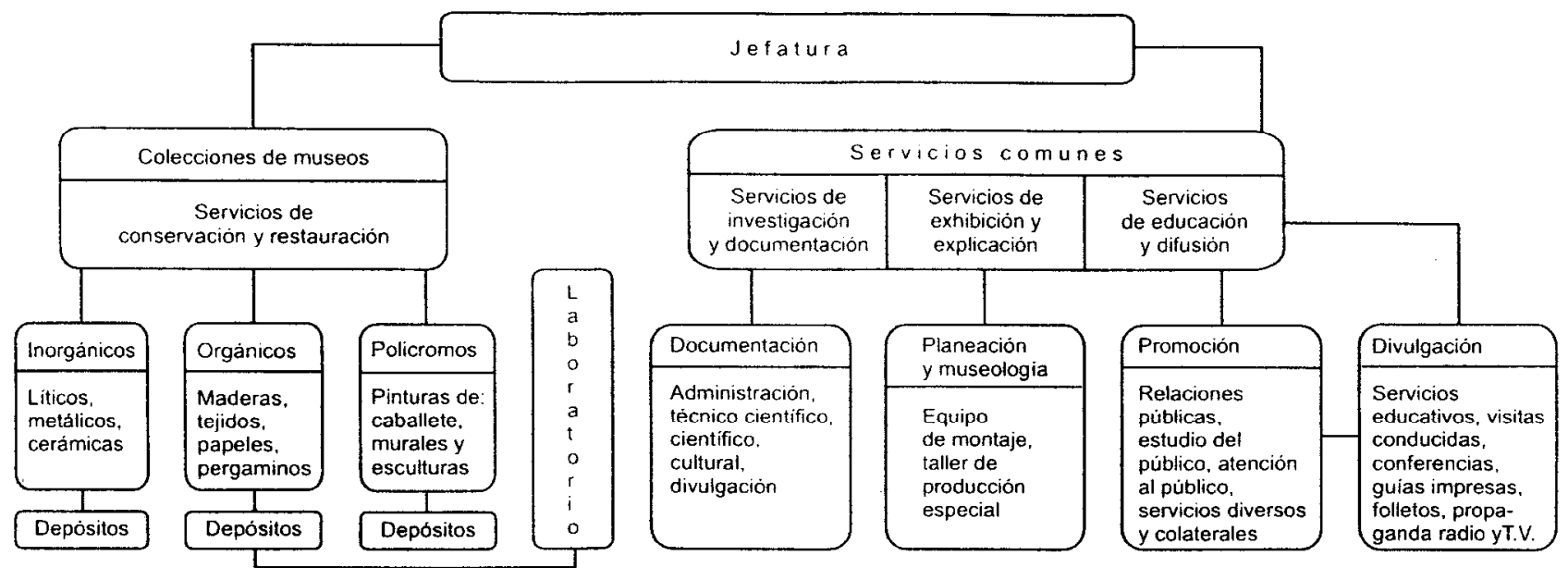

PROCESO MUSEOGRAFICO

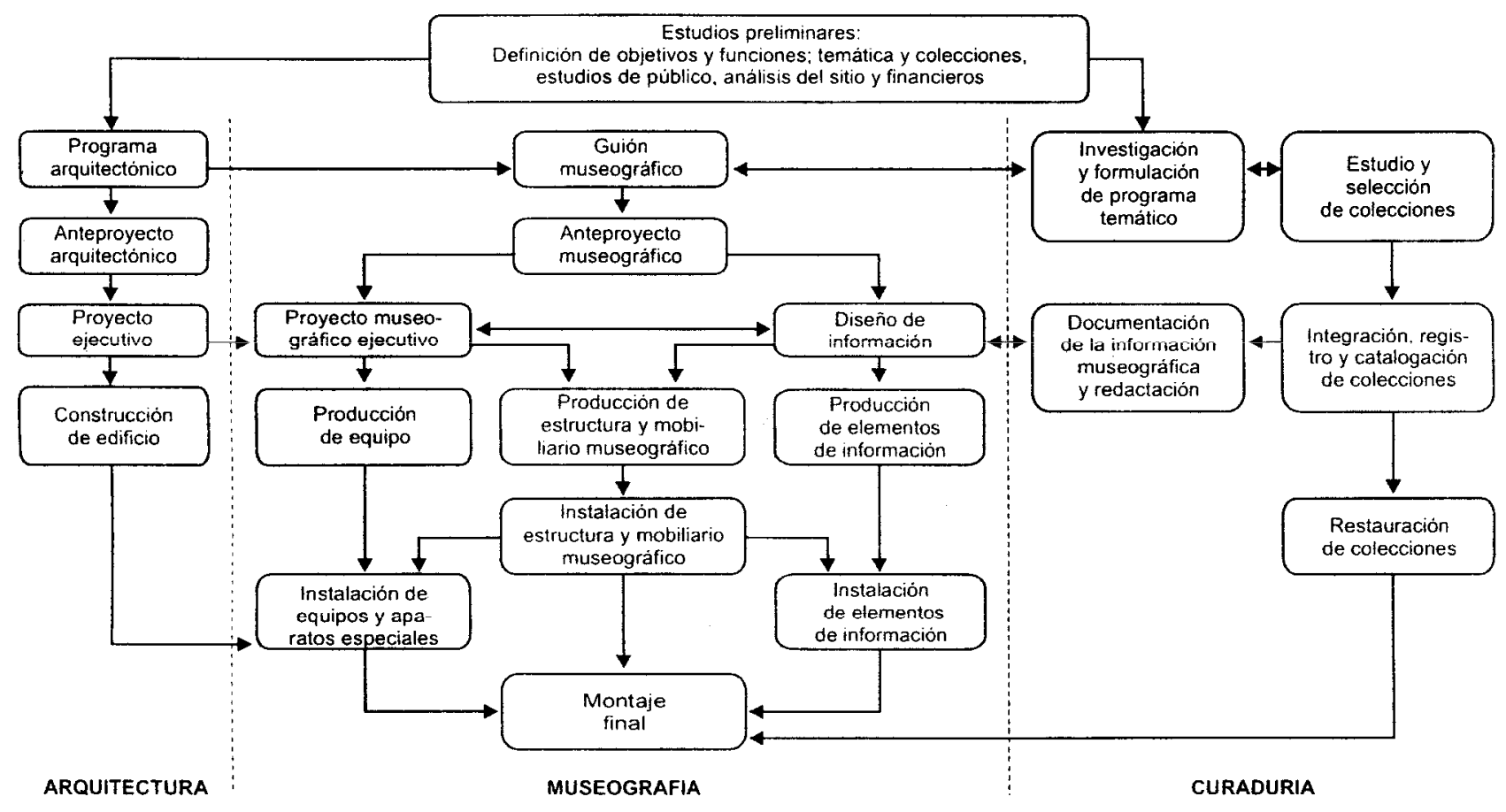

MOVIMIENTOS DE OBRAS DE ARTE

PLANEACION

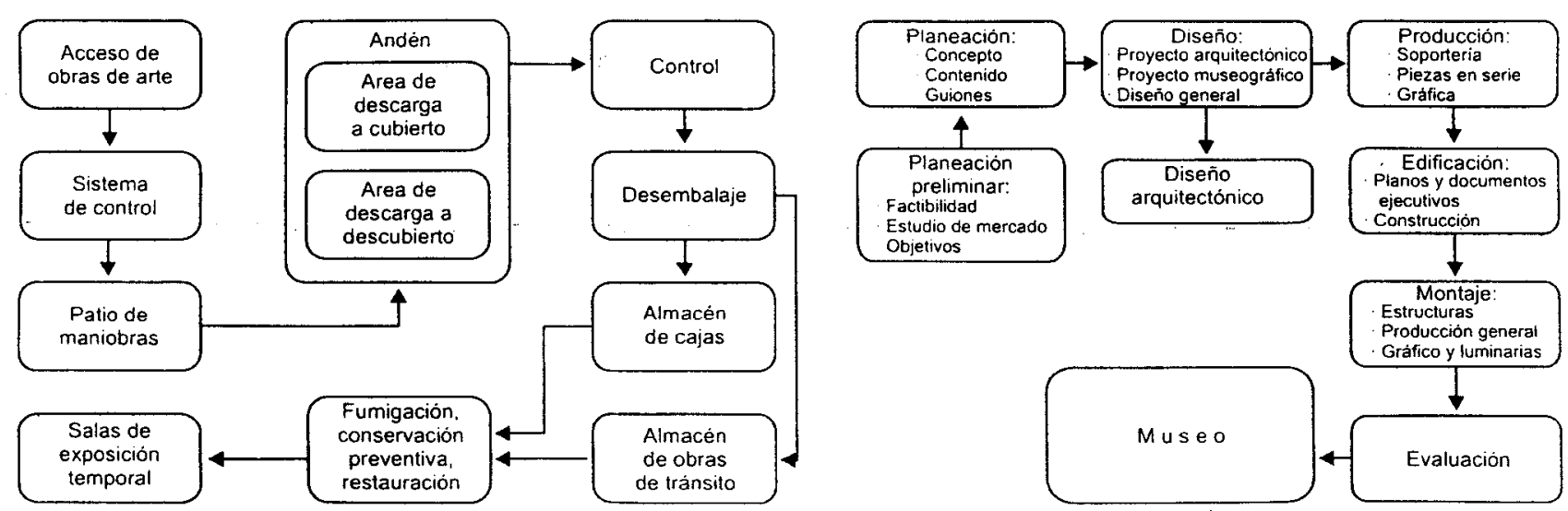

Diagramas de funcionamiento 